\title{
Global Justice Index Report 2020
}

\section{Yanfeng Gu ${ }^{1} \cdot$ Xuan Qin ${ }^{1} \cdot$ Zhongyuan Wang $^{1} \cdot$ Chunman Zhang $^{1}$ • Sujian Guo ${ }^{1}$ (D)}

Received: 11 March 2021 / Accepted: 23 March 2021 / Published online: 6 May 2021

(c) The Author(s) 2021

\begin{abstract}
The Global Justice Index is a multiyear research project conducted at the FudanIAS to conceptualize and measure each country's contribution to achieving greater global justice. In 2019, we completed our research project on first-year achievements, with the rankings of nation-states at the global level based on data from 2010 to 2017. This was published titled the "Global Justice Index Report" in Chinese Political Science Review (Vol. 5, No. 3, 2020). The "Global Justice Index Report 2020 " is the second annual report based on our work analyzing data from 2010 to 2018 , which was concluded in 2020. In order to better measure each country's performance and contribution to achieving greater global justice, compared to the first edition published in 2020, we have improved the model, added the refugee issue to expand the issue areas to 10, and added new indicators, regional analysis and comparison in this report. The report comprises five main sections. In the introduction, we discuss the development of the conceptual framework and evaluative principles to justify our selection of dimensions and indicators for measurement. Next, in the section of methodology, we discuss the production, normalization, and aggregation of the raw data and the generation of the final results. In the findings section, we report the data, indicators and our results for the ten issues, and provide regional comparisons. And then, in the following section we present the main results, and report the ranking of each country's contribution to achieving greater global justice. In the final section, we discuss the applications and limitations of the index, and its potential further research trajectories.
\end{abstract}

Keywords Global Justice Index · Indicators · Measurements · Methods · Country · Global rankings

This is a group project of Fudan IAS. All members of the group named as authors contributed equally to the study and ranked alphabetically.

Sujian Guo

sguo@fudan.edu.cn

1 Fudan Institute for Advanced Study in Social Sciences, Fudan University, Shanghai, China 


\section{Introduction}

The Global Justice Index is a multiyear research project conducted at the FudanIAS to conceptualize and measure each country's contribution to achieving greater global justice. In 2019, we provided our first-year achievements with the rankings of nation-states at the global level from 2010 to 2017. Based on the results, we have published a book in Chinese and an academic paper in English, which has received widespread attention. Building on the success of the previous year's work, in 2020, we intend to provide our second-year results with the rankings of nation-states at the global level from 2010 to 2018. This year's Global Justice Index (2020) report consists of five sections: introduction, methodology, results, analysis and conclusion.

In the introduction, we highlight our theoretical innovation by discussing the development of the conceptual framework to justify our selection of issues, dimensions and indicators for measurement. In addition, we present some major changes in this year's report compared with last year's report. Next, in our methodology section, we introduce our methods for production, normalization, and aggregation of the raw data and the generation of the final results. In the results section, we present the rankings of nation-states' contribution to global justice from 2010 to 2018. Following the results section, we provide regional comparisons with detailed policy analysis assisted with various visualization tools. In the last concluding section, we discuss the applications and limitations of the index, and its potential further research trajectories and policy implications for advancing global justice.

Global justice is a broad concept composed of multilevel and multidimensional aspects belonging to both normative and empirical realities. A coherent, integrated theoretical framework that covers the normative basis and various empirical dimensions is therefore necessary to address some of the basic and important questions under study. Our Global Justice Index study began with the conceptualization of global justice based on a theoretical paper titled "Conceptualizing and Measuring Global Justice: Theories, Concepts, Principles and Indicators," coauthored by the project leader, Sujian Guo et al. published in Fudan Journal of the Humanities and Social Sciences (Vol. 12, No. 4, 2019). The paper discusses theories, concepts, evaluative principles, and methodologies related to the study of global justice.

In the theoretical paper above (Guo et al. 2019), we attempt to clarify how to conceptualize global justice, how conceptual indicators can be selected and justified by theories, and how those indicators can be consistent with the concept of global justice. Through the synthesis of multiple theories and intellectual traditions in various cultural and political contexts, we conceptualize global justice from three main approaches-rights based, goods based, and virtue based-to develop a normatively based theoretical framework for measurement. Rights-based conceptualization focuses on the basic principles, rules, and sources of legitimacy of justice (Universal Declaration of Human Rights, 1948; Rawls, 1971, 1999). Goods-based conceptualization concentrates on the material 
and institutional supports that governments or institutions are obliged to provide (Arneson, 1989; Freeman, 2006; Nussbaum, 2006, 2011; Richardson, 2006). And virtue-based conceptualization regards justice as a virtue that an individual is willing to pursue rather than a regulation an individual is forced to comply with (Mo, 2003). The relationship between the three approaches of conceptualization is interdependent rather than separate, which indicates three interrelated components of a holistic whole. Additionally, the three approaches are complementary rather than competing, with the rights-based conceptualization forming the basic structure ("the bones"), the goods-based conceptualization providing substantial material supports ("the muscles", and the virtue-based conceptualization emphasizing personal motivation and internalized willingness ("the heart)" (Guo et al., 2019).

Based on the aforementioned theoretical framework, we propose two evaluative principles to further bridge the gap between theory and practice to determine and justify our selection of issue areas for evaluation. We call the two principles Common but Differentiated and Respective Capabilities (CBDR-RC) and Cosmopolitan but Due-diligent Responsibilities (CDDR). CBDR-RC addresses the issues "for which no single nation-state can be held directly accountable or responsible, matters that can only be tackled through the globally concerted efforts of all stakeholders" (Guo et al. 2019). For example, it is the responsibility of all to protect the climate system and ecological balance, and environmental protection is a task that cannot be handled by one country on its own. The principle of CBDR-RC, first adopted by the United Nations Framework Convention on Climate Change and reaffirmed in the Rio Declaration on Environment and Development, combines normative legitimacy and historical rationality. Although it was a principle that first aimed to determine the responsibilities of each country for climate change, it has been expanded to other global justice areas such as combatting transnational crime and global peacekeeping.

The second principle, CDDR, addresses that "all-nation-states are morally obligated to provide cosmopolitan aid, in which context the least advantaged will have a due-diligent responsibility" (Guo et al. 2019). This principle is based on the concept of "mutual accountability" proposed in the Paris Declaration on Aid Effectiveness, adopted in 2005 at the Second High-Level Forum on Aid Effectiveness to promote better cooperation between different actors in aid and development. This principle views such obligations as part of domestic affairs, such as anti-poverty and education policy, in the context of which nation-states are expected to provide material and institutional assistance to their citizenry within their territories.

According to the principles of CBDR-RC and CDDR, we have selected two clusters of global justice issue areas for practical measurement. Those issue areas that follow the principle of CBDR-RC are (1) climate change (global warming), (2) peacekeeping, (3) humanitarian aid, (4) terrorism and armed conflicts, (5) crossnational criminal police cooperation, (6) refugees; and those belonging to the principle of CDDR are (7) anti-poverty, (8) education, (9) public health and (10) the protection of women and children.

This year's Global Justice Index study is not simply a continuation of last year's work. To further improve the quality of our index, we have made a few major modifications. First of all, we have perfected our selection of issue areas and indicators by 
adding a brand new issue area and more indicators to our study. In the Global Justice Index (2019), we have selected nine issues areas to construct the index. The issue of refugees has been included in this year's Global Justice Index as more and more attention has been devoted to the fermenting refugee crisis. For other issue areas, indicator systems have been either kept unchanged or improved. Second, we have slightly modified our research methodology to better calculate the index (for more information, please see the next section). Third, we have changed our indicators and included more data in our calculation. Last, we have strengthened our analysis section by incorporating and discussing more literature and policy implications. As such, readers from different backgrounds can all benefit.

Due to these new changes, readers may find that some countries' rankings in this year's Global Justice Index are quite different from those in the Global Justice Index (2019), while other countries' rankings have not changed substantially. This should not be a surprise to our readers. Global justice is a cutting-edge research field which involves sophisticated materials, a large volume of data and a changing international landscape. We aim to keep our results consistent across different years. At the same time, we do make necessary and important modifications to our research design in light of a changing international environment and the availability of new and better data.

\section{Methodology: Construction of the Global Justice Index}

In this study, we classify our data into four levels: indicators, dimensions, categories, and issues. The first and lowest level of our data provides the information on indicators, which is our raw data. The second level is named dimensions, which usually comprises several related indicators. The third level is categories and comprises several related dimensions. And the highest level is the issue index, usually calculated based on two categories: contribution and performance.

The global justice index is calculated as follows:

\subsection{First step: Convert Indicator Indices}

To ensure comparability between indicators, we use the following two formulas to convert the raw data into comparable indicators:

$$
\begin{gathered}
i i_{i j}=\frac{\text { actualvalue }_{i j}-\min \left(\text { actualvalue }_{j}\right)}{\max \left(\text { actualvalue }_{j}\right)-\min \left(\text { actualvalue }_{j}\right)}+1 \\
i i_{i j}=\frac{\max \left(\text { actualvalue }_{j}\right)-\text { actualvalue }_{i j}}{\max \left(\text { actualvalue }_{j}\right)-\min \left(\text { actualvalue }_{j}\right)}+1 \\
i \in\{1,2, \cdots 192\}, j \in\{2010,2011, \cdots 2018\},
\end{gathered}
$$


where actualvalue $e_{i j}$ indicates the actual value of an indicator in country $i$ in year $j$, $\min \left(\right.$ actualvalue $\left._{. j}\right)$ is the minimum value of an indicator among all countries in year $j$ and $\max \left(\right.$ actualvalue $\left._{. j}\right)$ is the maximum value of an indicator among all countries in year $j$. If an indicator positively relates to global justice, the first formula is used to convert the raw data; if not, the second formula is used.

\subsection{Second step: Population-Based Weighting}

Consciously, efforts made to raise the welfare of their populations to the same level have a comparatively larger overall impact in countries with larger populations; therefore, we weight indicators based on population size. We proceed as follows:

First, we calculate the weighted average of an indicator as per the following formula:

$$
i i_{m j}=\frac{\sum i_{i j} * \text { population }_{i j}}{\sum \text { population }_{i j}} .
$$

where $i i_{m j}$ is the weighted average of an indicator. $i i_{i j}$ is the actual value of an indicator in country $i$ in year $j$. population $n_{i j}$ is the population size of country $i$ in year $j$.

Second, we calculate the weight of each country on an indicator as follows:

$$
s s_{i j}=\left(i i_{i j}-i i_{m j}\right) * \text { population }_{i j},
$$

where $s s_{i j} i$ s the weight of country $i$ in year $j$.

Third, we calculate the score for an indicator in country $i$ in year $j$ as follows:

$$
I I_{i j}=\frac{s s_{i j}-\min \left(s s_{. j}\right)}{\max \left(s s_{. j}\right)-\min \left(s s_{. j}\right)}+1,
$$

where $I I_{i j}$ is the score of an indicator in country $i$ in year $j$. We use $I I_{i j}$ to further calculate the dimension global justice.

\subsection{Third step: Calculate the Scores of Both Dimension Indices and Category Indices}

For each variable, we calculate the score of the dimension index as follows:

$$
D I_{i j}=\frac{1}{k} \sum I I_{i j k}
$$

where $I I_{i j}$ is the score of an indicator in country $i$ in year $j$, and $\mathrm{K}$ is the number of indicators in a specific dimension in country $i$ in year $j$.

Similarly, we use $D I_{i j}$ to further calculate the score of category indices as follows:

$$
V I_{i j}=\sqrt[n]{\prod_{k} D I_{i j k}}
$$




\subsection{Fourth step: Calculate the Score of the Issue Index}

We use $V I_{i j}$ to further calculate the score of each issue in county $i$ in year $j$ as follows:

$$
I S I_{i j}=\sqrt[n]{\prod_{k} V I_{i j k}}
$$

\subsection{Last step: Calculate Global Justice Index}

We use the following formula to calculate the score of the global justice index in country $i$ in year $j$ :

$$
G J_{i j}=\sqrt[10]{\prod_{k} I S I_{i j k}},
$$

where $G J_{i j}$ is the score of global justice in country $i$ and year $j . I S I_{i j k}$ is the score of issue $k$ in country $i$ in year $j$.

\section{Findings}

\subsection{Issue 1: Climate Change}

\subsubsection{Introduction}

Nowadays, more and more people around the globe have realized that climate change is a global challenge facing our planet, closely related to the survival of human beings and the continuation of our civilization. Climate change will bring about many problems, such as extreme weather, melting ice and snow, rising sea levels, frequent mountain fires and so on. Climate change has been a feature of the evolution of the earth itself, and it has long been a completely natural phenomenon, without significant human intervention. But with the development of mankind, more and more human activities have been linked to climate change. For example, the industrial production process needs to consume a substantial amount of fossil energy, which causes a lot of greenhouse gases to be emitted into the air, further enhancing global warming. Many activities in our daily lives are also emitting greenhouse gases into the air. The increase in the earth's temperature caused by climate change will have an irreversible impact and cause harm to human production and life, so all countries in the world must act.

The issue of climate change is also a global justice issue, because it involves the distribution of responsibilities and obligations between all of the developing and developed countries in the world. The signing of the Paris Climate Agreement in 2015 was a milestone event for dealing with the climate change issue, which shows the strong determination of governments of all countries to cooperate to solve the problem of global warming. However, the Trump administration's withdrawal from 
the Agreement in recent years has cast a shadow on global climate governance. With the victory of Joe Biden in the 2020 US election, the United States is very likely to return to the field of global climate governance and even push countries to take more measures to deal with climate change. The Climate Ambition Summit which was held in December 2020 shows a new surge in action and ambition to control global warming. As a matter of fact, countries are taking various measures to advance their national determined contribution targets, but how well each country is doing in reality remains unknown. Our Global Justice Index research will answer this question through data analysis.

\subsubsection{Dimensions and Indicators}

The issue of global warming has prompted worldwide discussion. At the beginning of this century, Thomas Crowley published an important research paper in Science, arguing that "natural variability plays only a subsidiary role in the twentieth-century warming and that the most parsimonious explanation for most of the warming is that it is due to the anthropogenic increase in GHG". ${ }^{1}$ This research finding is consistent with the definition of climate change in the United Nations Framework Convention on Climate Change which defines climate change as a change of climate which is attributed directly or indirectly to human activity that alters the composition of the global atmosphere and which is in addition to natural climate variability observed over comparable time periods. According to these scientific research results and the definition of climate change of the United Nations, our empirical analysis for measuring countries' contributions to solving climate change includes four dimensions: energy consumption, electricity production, $\mathrm{CO} 2$ and forests.

We have obtained highly reliable open source data from prestigious international organizations, research institutions, and multinational companies, such as forest data from the United Nations Environment Programme, and carbon dioxide-related data from the Global Carbon Project. Based on these open source data, we design three to five indicators for each dimension. For example, in the energy consumption dimension, our indicators include primary energy consumption in total, primary energy consumption per capita, oil consumption, natural gas consumption, and coal consumption. In the electricity production dimension, our indicators include electricity production in total, electricity production from nuclear sources, electricity production from hydroelectric sources, Electricity production from renewable sources excluding hydroelectric. In the dimension of $\mathrm{CO} 2$, our indicators include $\mathrm{C} 02$ emissions, C02 emissions per GDP and C02 emissions per capita. In the forest dimension, our indicators include forest area in total, forest area change rate, forest area per capita, forest coverage, planted forest area. In order to better reflect the contributions of countries around the world in the current battle against climate change in the past decade, the time span that we focus on in this project is from 2010 to 2018. Last year's Global Justice Index research on climate change covers 192 countries around the world, but the time frame is from 2010 to 2014. This year we have done a better

${ }^{1}$ Crowley (2000). 


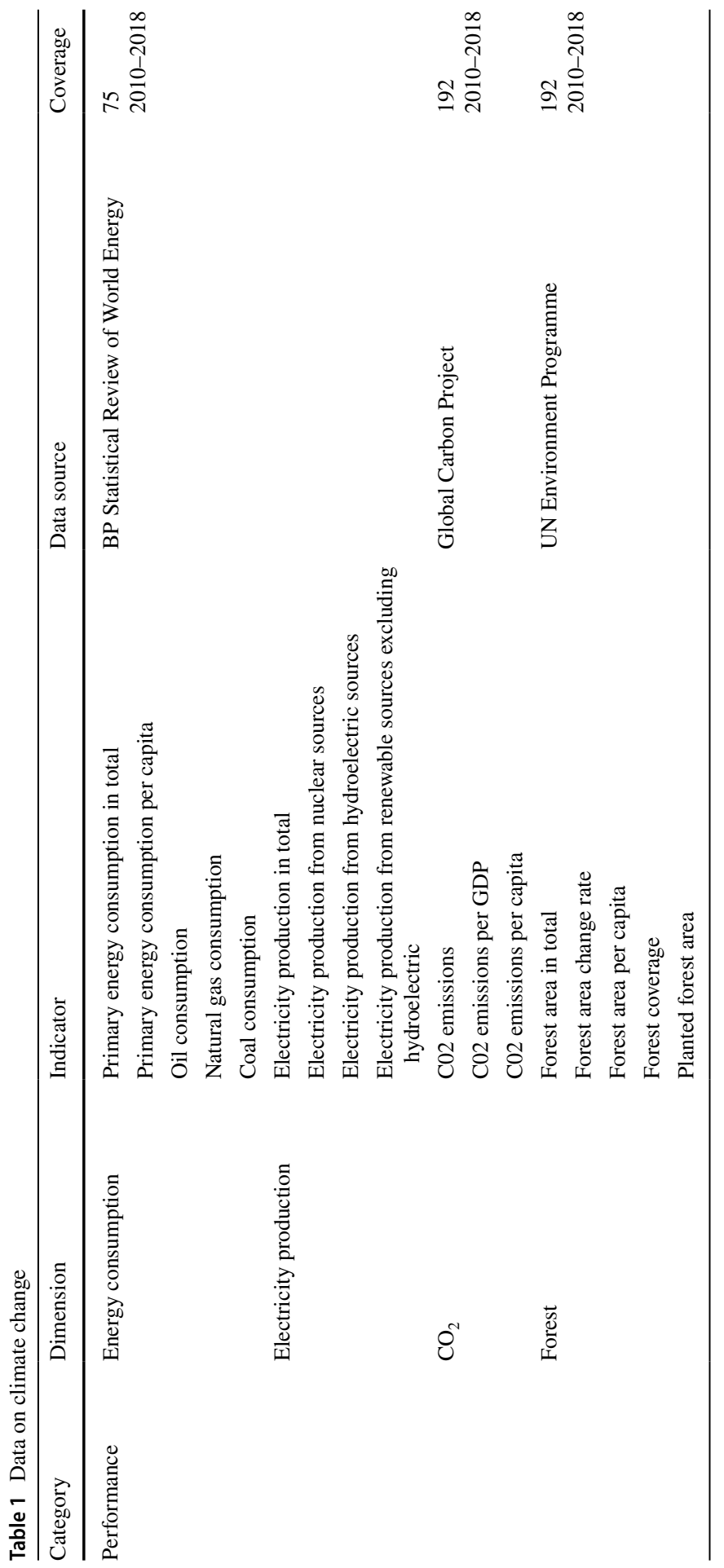


job in terms of time frame than last year, but this year's research can only cover 75 countries, which leaves some small and medium-sized countries omitted. We are fully aware that the scale of national coverage is a major shortcoming of this year's research due to the lack of reliable data, but the comprehensive indicator system can make sure that we can have a sound calculation of 75 countries' contributions to global justice from the perspective of fighting climate change. We will keep looking for better and comprehensive data to cover more countries in the future (Table 1).

\subsubsection{Results}

In this section, we present the ranking results of the countries' contributions to global justice from a climate change perspective (Table 2). Table 2 shows 9 years of results from 2010 to 2018 in 75 countries.

The table above shows that from 2010 to 2018, Brazil, Canada, Sweden, Russia, France, Finland, Peru, Colombia and other countries have consistently performed well in climate change. Among them, Brazil, Russia, Peru and Colombia are developing countries while Canada, Sweden, France and Finland are developed ones. China's performance in climate change over the previous years has been very impressive, and it is a good model for developing countries. In 2010, China ranked 18 th in terms of climate change performance. After that, the progress was very obvious. It entered the top 10 in 2014 and has risen to 5th in 2018. Among the entire 75 countries, developing countries have done worse than developed countries. Saudi Arabia, Kazakhstan, Trinidad and Tobago, Qatar and other countries ranked low. In addition, some countries' climate change ranking has shown great volatility. For example, the United Kingdom has risen from 48 in 2010 to 34 in 2018, showing a clear upward trend; Algeria has dropped from 26 in 2010 to 58 in 2018, showing a clear downward trend; and Japan first drops and then rises, forming a V-shaped fluctuating change.

Brazil's ranking from 2010 to 2018 is quite stable because its vast forests make it score higher in the forest dimension, and its performance in the other three dimensions is also excellent. Brazil has a vast Amazon forest, however, the forest area change rate in Brazil has consistently been negative from 2010 to 2018. As such, Brazil ranks 5th in the forest dimension score, i.e. not the first in the world. Canada scored higher in the dimensions of forests and electricity generation. However, because it scored slightly lower in the dimensions of carbon emissions and energy consumption, in the end it ranked second after Brazil. Sweden, which ranked third in 2018, scored lower than Canada in the dimensions of forests and electricity generation. Sweden has a higher score in carbon emissions, and has a slightly higher score in energy consumption than Canada. Russia scored very high in the dimensions of forests and electricity generation, and scored low in terms of carbon emissions and energy consumption. Thanks to the rapid development and energy saving and emission reduction policies in the past 10 years, China scored high both in electricity generation and carbon emissions. These significant improvements are key reasons why its ranking rose from 18th in 2010 to 5 th in 2018. France has a high score in the dimensions of carbon emissions and electricity generation, and a low score in the dimensions of forests and energy consumption. Contrary to France, Finland has 
a low score in the dimensions of energy consumption and carbon emissions and has a medium score in the dimension of electricity generation. Finland's forest dimension score is higher. Peru scored very highly in the energy consumption, carbon emissions, and forest dimensions, but it scored very low on electricity generation. Similarly, Colombia also has higher scores in the dimensions of energy consumption and carbon emissions; but its score in the electricity generation dimension is slightly higher than Peru, and its score in the forest dimension is slightly lower than Peru, thus the overall ranking is lower than Peru.

The lowest ranking countries in the field of climate change are Saudi Arabia, Kazakhstan, Trinidad and Tobago, and Qatar. The major reason for the low ranking of these countries is that they are generally less capable of addressing climate change. Part of the reason comes from their low scores on forests and carbon emissions. Both Saudi Arabia and Qatar are Middle Eastern countries with relatively few forest resources. Although the scores of these two countries in the forest dimension are on the rise, they are still relatively small compared to other countries. Qatar performed worst because of its poor performance in all aspects. Kazakhstan's forest score is also relatively low, and the gap with Saudi Arabia is not very large, but Kazakhstan's performance in carbon emissions and power generation is weaker than Saudi Arabia; thus it ranks lower than Saudi Arabia.

The United States' rankings over the years have not been in the top 10. The Democratic Party in the United States is more concerned about climate change issues than the Republican Party. During the Obama administration, the United States performed relatively well on climate change. However, after the 2016 U.S. election, Donald Trump became President of the United States. He strongly supported traditional energy, not new energy, and was very indifferent to the issue of climate change. This led to a significant decline in the ranking of the United States in 2018. The British government has attached great importance to climate change issues in the past few years. ${ }^{2}$ Judging from the scores of the four dimensions, the UK is in an upward phase in the four dimensions of electricity generation, carbon emissions, energy and forests. According to this trend, the UK's ranking in the future is expected to rise.

Germany's ranking is in a downward trend at this stage. On the whole, Germany's performance in the three dimensions of power generation, carbon emissions and forests is good. However, as a major manufacturing country, Germany's carbon emissions are relatively large, thus dragging down Germany's overall performance. Germany changed its attitude towards nuclear power generation after the Fukushima nuclear accident in Japan. The Merkel government has gradually shut down more nuclear power generation in the past few years and plans to close all nuclear power plants in the country by 2022. This has caused Germany's score in power generation to drop substantially, which is also an important reason for the decline in Germany's ranking year by year. But in the long run, we are relatively optimistic about Germany's ability to deal with climate change. Germany is a leader and pioneer in developing renewable energy and promoting low-carbon development. The German

\footnotetext{
2 Johnston \& Deeming (2016).
} 
Table 2 Country ranking in the climate change aspect of promoting global justice

\begin{tabular}{|c|c|c|c|c|c|c|c|c|c|}
\hline Country & 2010 & 2011 & 2012 & 2013 & 2014 & 2015 & 2016 & 2017 & 2018 \\
\hline Brazil & 1 & 1 & 1 & 1 & 1 & 1 & 1 & 1 & 1 \\
\hline Canada & 2 & 2 & 2 & 2 & 2 & 2 & 2 & 2 & 2 \\
\hline Sweden & 3 & 3 & 3 & 3 & 3 & 3 & 3 & 3 & 3 \\
\hline Russian Federation & 4 & 4 & 4 & 4 & 4 & 4 & 4 & 4 & 4 \\
\hline China & 18 & 18 & 16 & 12 & 10 & 7 & 5 & 5 & 5 \\
\hline France & 6 & 5 & 5 & 5 & 5 & 5 & 6 & 6 & 6 \\
\hline Finland & 9 & 7 & 6 & 7 & 6 & 6 & 7 & 7 & 7 \\
\hline Peru & 7 & 6 & 7 & 6 & 7 & 8 & 8 & 8 & 8 \\
\hline Colombia & 10 & 11 & 10 & 9 & 9 & 11 & 11 & 9 & 9 \\
\hline Philippines & 36 & 9 & 9 & 8 & 8 & 9 & 9 & 10 & 10 \\
\hline Japan & 5 & 8 & 15 & 17 & 15 & 13 & 12 & 12 & 11 \\
\hline Latvia & 13 & 14 & 13 & 13 & 14 & 14 & 13 & 13 & 12 \\
\hline Viet Nam & 12 & 16 & 14 & 14 & 16 & 16 & 16 & 14 & 13 \\
\hline United States of America & 14 & 10 & 8 & 11 & 11 & 10 & 10 & 11 & 14 \\
\hline Spain & 8 & 12 & 11 & 10 & 12 & 15 & 14 & 15 & 15 \\
\hline Chile & 34 & 20 & 20 & 20 & 19 & 18 & 17 & 17 & 16 \\
\hline Slovenia & 22 & 25 & 24 & 24 & 20 & 19 & 19 & 18 & 17 \\
\hline Germany & 11 & 13 & 12 & 15 & 13 & 12 & 15 & 16 & 18 \\
\hline Malaysia & 17 & 22 & 22 & 26 & 22 & 21 & 22 & 19 & 19 \\
\hline Indonesia & 15 & 17 & 19 & 16 & 17 & 17 & 18 & 20 & 20 \\
\hline Romania & 35 & 31 & 30 & 25 & 23 & 23 & 21 & 22 & 21 \\
\hline Ecuador & 19 & 21 & 18 & 21 & 26 & 24 & 23 & 21 & 22 \\
\hline Switzerland & 30 & 29 & 29 & 30 & 28 & 27 & 26 & 25 & 23 \\
\hline Sri Lanka & 21 & 24 & 25 & 23 & 27 & 28 & 28 & 26 & 24 \\
\hline Italy & 28 & 23 & 21 & 19 & 18 & 20 & 20 & 24 & 25 \\
\hline New Zealand & 23 & 27 & 28 & 28 & 29 & 29 & 25 & 29 & 26 \\
\hline Austria & 25 & 28 & 26 & 27 & 25 & 26 & 27 & 28 & 27 \\
\hline India & 16 & 15 & 17 & 18 & 21 & 22 & 24 & 23 & 28 \\
\hline Norway & 24 & 26 & 27 & 29 & 30 & 30 & 29 & 27 & 29 \\
\hline Lithuania & 29 & 34 & 33 & 32 & 31 & 33 & 31 & 31 & 30 \\
\hline Venezuela (Bolivarian Republic of) & 20 & 19 & 23 & 22 & 24 & 25 & 30 & 30 & 31 \\
\hline Azerbaijan & 27 & 30 & 31 & 31 & 33 & 34 & 33 & 32 & 32 \\
\hline Mexico & 32 & 33 & 35 & 34 & 35 & 35 & 34 & 34 & 33 \\
\hline $\begin{array}{l}\text { United Kingdom of Great Britain } \\
\text { and Northern Ireland }\end{array}$ & 48 & 40 & 40 & 39 & 37 & 32 & 32 & 33 & 34 \\
\hline Slovakia & 39 & 38 & 36 & 37 & 36 & 36 & 37 & 35 & 35 \\
\hline Portugal & 31 & 32 & 34 & 33 & 34 & 37 & 36 & 37 & 36 \\
\hline Thailand & 38 & 37 & 38 & 38 & 39 & 41 & 40 & 38 & 37 \\
\hline Turkey & 37 & 36 & 37 & 36 & 38 & 38 & 38 & 39 & 38 \\
\hline Republic of Korea & 33 & 35 & 32 & 35 & 32 & 31 & 35 & 36 & 39 \\
\hline Bulgaria & 43 & 46 & 43 & 40 & 43 & 45 & 42 & 43 & 40 \\
\hline Greece & 44 & 42 & 44 & 43 & 41 & 40 & 39 & 41 & 41 \\
\hline Belarus & 42 & 39 & 39 & 41 & 40 & 39 & 41 & 40 & 42 \\
\hline
\end{tabular}


Table 2 (continued)

\begin{tabular}{llllllllll}
\hline Country & 2010 & 2011 & 2012 & 2013 & 2014 & 2015 & 2016 & 2017 & 2018 \\
\hline Denmark & 47 & 44 & 42 & 44 & 44 & 42 & 43 & 42 & 43 \\
Hungary & 41 & 41 & 41 & 42 & 42 & 43 & 44 & 44 & 44 \\
Bangladesh & 45 & 43 & 46 & 45 & 47 & 48 & 46 & 46 & 45 \\
Poland & 46 & 45 & 45 & 46 & 45 & 44 & 45 & 45 & 46 \\
Australia & 54 & 47 & 47 & 47 & 46 & 46 & 47 & 47 & 47 \\
Czechia & 50 & 50 & 48 & 49 & 48 & 49 & 49 & 48 & 48 \\
Ireland & 51 & 49 & 50 & 50 & 49 & 50 & 50 & 49 & 49 \\
Morocco & 40 & 48 & 49 & 48 & 50 & 51 & 48 & 50 & 50 \\
Israel & 59 & 56 & 56 & 54 & 52 & 53 & 53 & 53 & 51 \\
Egypt & 49 & 51 & 54 & 52 & 55 & 54 & 54 & 54 & 52 \\
Cyprus & 53 & 53 & 53 & 51 & 53 & 55 & 55 & 55 & 53 \\
Belgium & 55 & 52 & 52 & 53 & 51 & 52 & 52 & 51 & 54 \\
Estonia & 56 & 55 & 51 & 56 & 54 & 47 & 51 & 52 & 55 \\
Luxembourg & 62 & 62 & 61 & 59 & 57 & 56 & 56 & 56 & 56 \\
Argentina & 52 & 54 & 55 & 55 & 56 & 57 & 58 & 58 & 57 \\
Algeria & 26 & 57 & 57 & 57 & 58 & 58 & 57 & 57 & 58 \\
Ukraine & 63 & 63 & 63 & 62 & 62 & 60 & 61 & 59 & 59 \\
Netherlands & 58 & 58 & 58 & 58 & 59 & 59 & 59 & 60 & 60 \\
Uzbekistan & 66 & 67 & 67 & 65 & 65 & 64 & 64 & 63 & 61 \\
Singapore & 64 & 61 & 62 & 63 & 63 & 63 & 60 & 62 & 62 \\
Iraq & 57 & 59 & 60 & 60 & 61 & 61 & 62 & 61 & 63 \\
Iceland & 60 & 60 & 59 & 61 & 60 & 62 & 63 & 64 & 64 \\
Pakistan & 61 & 64 & 64 & 64 & 64 & 65 & 65 & 65 & 65 \\
South Africa & 67 & 66 & 66 & 67 & 67 & 66 & 67 & 66 & 66 \\
Iran (Islamic Republic of) & 65 & 65 & 65 & 66 & 66 & 67 & 66 & 67 & 67 \\
Oman & 68 & 68 & 68 & 68 & 68 & 68 & 68 & 68 & 68 \\
Turkmenistan & 73 & 72 & 72 & 70 & 70 & 71 & 69 & 69 & 69 \\
United Arab Emirates & 69 & 70 & 70 & 72 & 72 & 70 & 71 & 71 & 70 \\
Kuwait & 71 & 73 & 73 & 73 & 71 & 72 & 72 & 72 & 71 \\
Saudi Arabia & 72 & 71 & 71 & 71 & 73 & 73 & 73 & 73 & 72 \\
Kazakhstan & 70 & 69 & 69 & 69 & 69 & 69 & 70 & 70 & 73 \\
Trinidad and Tobago & 74 & 74 & 74 & 74 & 74 & 74 & 74 & 74 \\
Qatar & 75 & 75 & 75 & 75 & 75 & 75 & 75 \\
\hline & & & & & & & &
\end{tabular}

government believes that climate protection not only provides long-term guarantees for sustainable economic development, but also brings direct benefits to the German economy. Therefore, it has been actively participating in and promoting action against climate change. Looking at recent history, we found that Germany passed the "Energy Utilization and Climate Protection Package" in 2007, and subsequently passed the "Biofuel Oil Ratio Law", the "Renewable Energy Heating Law", and the "Vehicles A series of related legislations including the Purchase Tax Reform Law, 
which stipulates that the new car purchase tax rate is linked to the size of the vehicle engine and the level of carbon dioxide emissions. Germany also has strong technical strength in the development of wind power generation, and its ranking may show an upward trend in the future.

India's ranking is generally in decline. As the second largest developing country in the world after China, India is facing great pressure on the issue of climate change. India's scores on the three dimensions of energy, carbon emissions and power generation are all falling, and the only growth is in the forest dimension. From 2010 to 2018, India's economy and population are still growing rapidly, especially since the Modi government came to power, India's economic development has accelerated. Some studies have found that India has begun to suffer severe impacts from climate change, especially in the agricultural sector. ${ }^{3}$ But India has yet to find a better way and build greater determination to deal with climate change.

The Dutch ranking in climate change has been around 60 for a long time, which may surprise some readers. As a major developed country, the performance of the Netherlands in tackling climate change is far worse than other developed countries and even many developing ones. Our research shows that the Netherlands performs well in the two dimensions of energy and carbon emissions, but its performance in the two dimensions of forests and power generation is poor, which is the main reason for its relatively backward ranking. Electricity generation in the Netherlands is highly dependent on thermal power plants, which rely on a large amount of fossil energy. The situation in Iceland is similar to that in the Netherlands. Iceland is even worse than the Netherlands in the three dimensions of carbon emissions, power generation and energy consumption, but it performs much better than the Netherlands in the forest dimension. As a developed country, Belgium ranks slightly higher than the Netherlands and Iceland, but it is also in a relatively backward position within the group of developed countries. The reason is that from a data point of view, Belgium ranks relatively low in the two dimensions of forests and power generation.

Japan's ranking decline over the past 9 years is mainly related to the leak at the Fukushima nuclear power plant in 2011. After the accident, the abandonment of nuclear power was one of the main response measures of the Japanese government. In May 2011, Japan's last nuclear power plant in operation, the Hokkaido Tomari Nuclear Power Plant, ceased power generation. In July 2011, the then Prime Minister of Japan proposed the goal of "establishing a society without nuclear power." Because of the reduction in nuclear power, Japan's score in power generation has fallen. The later prime minister led the formulation of Japan's new energy and environmental strategy, making it clear that Japan's dependence on nuclear power will be zero by 2030. As a result, Japan's score on the power generation dimension has dropped consistently, leading to a decrease in its ranking. However, in recent years, Japan has seen some new changes in its attitude towards nuclear power, and it has begun to again support a role for nuclear power in the national energy system. This is the main reason why Japan's climate change rankings are beginning to rise.

\footnotetext{
${ }^{3}$ India: The Impact of Climate Change to 2030. https://www.dni.gov/files/documents/climate2030_ india.pdf.
} 


\subsubsection{Regional Analysis}

In 2018, the top Ten countries in the field of climate change were Brazil, Canada, Sweden, Russia, China, France, Finland, Peru, Colombia, and the Philippines. Among the top ten countries, there are four countries in the Americas, two Asian countries, four European countries, but African countries are not included in the top ten. There are six developing countries and four developed countries (Fig. 1). This shows that the degree of economic development is not necessarily related to the response to climate change. Both developed and developing countries have the opportunity to play an important role in the response to climate change. These countries are able to rank high in the field of climate change because they have some common characteristics. First, these countries generally attach importance to climate change issues. Different countries have different understanding of climate change issues. ${ }^{4}$ For example, the Trump administration of the United States has a very negative attitude towards climate change, and the U.S. government even withdrew from the Paris climate agreement. However, these top 10 countries have not only signed and maintained the Paris climate agreement, but have also been taking many measures to increase their nationally determined contributions. Second, these countries generally have no obvious shortcomings in the four dimensions of energy consumption, carbon emissions, power generation and forests. In other words, the top-ranked countries have performed well in major aspects of tackling climate change. Finally, these countries tend to be particularly prominent in certain aspects of responding to climate change. For example, Russia and Canada have outstanding performance in the forest dimension. China has outstanding performance in the two dimensions of power generation and forests. After signing the Paris Agreement in 2015, China has become more proactive in promoting the transition to low-carbon social and economic development. Renewable energy power generation is developing rapidly in China. China has also invested a lot of money, manpower and material support in afforestation.

It should be noted that the analysis of climate change is based on statistical data of 75 countries, so it reflects the relative ranking of these 75 countries. From an absolute point of view, the lower-ranking countries in the climate rankings may not be worse.

Next, we classify countries according to their continents. These continents include Asia, Europe, North America, Latin America, Africa and Oceania. The ranking of each continent is obtained by calculating the average of the rankings of these countries. We drew a line chart to achieve a visual presentation to compare the differences in the contribution of various continents to climate change.

Seventy-five countries are included in the six continents, of which there are more countries in Europe and Asia and less countries in Oceania and North America (Fig. 2). According to the average number of scores, the top overall rankings are North American countries, followed by Latin American countries and European countries. The lowest overall ranking is African countries. The reason why North

\footnotetext{
${ }^{4}$ Adger et al. (2011)
} 


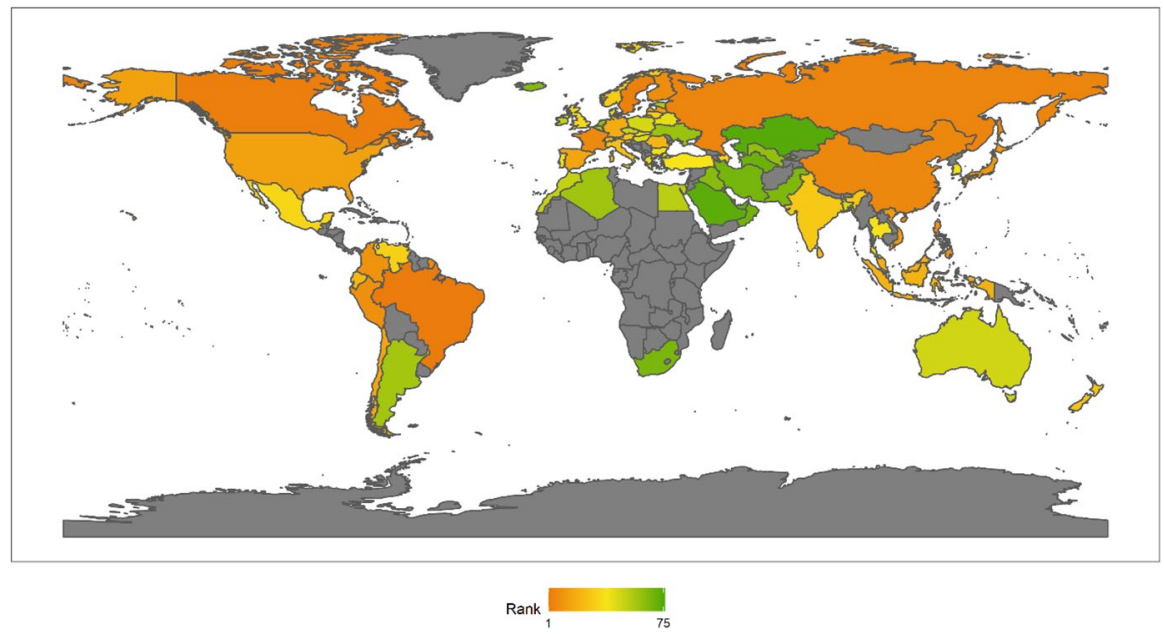

Fig. 12018 Index ranking of climate change on a world map

American countries rank high is because North America has only two countries in our ranking, the United States and Canada. The rankings of these two countries are very high. Africa is at the bottom of the ranking because the selected African countries are generally at the bottom, and no country has performed well in addressing climate change. From the comparison of various continents, the ability and level of various regions to cope with climate change are extremely uneven. Africa, with the largest concentration of developing countries, needs more support and help from other countries.

Asia In 2018, we found that the top three Asian countries are China, the Philippines, and Japan, and the bottom countries are Qatar, Kazakhstan, and Saudi Arabia. After the Copenhagen Conference, China changed its attitude towards climate change and began to take more active measures to address the challenges of climate change. In 2013, the Chinese government officially released the "National Climate Change Strategy." In 2015, China signed the Paris Climate Agreement and actively fulfilled its emission reduction obligations. At the General Debate of the 75th UN General Assembly in 2020, Chinese President Xi Jinping announced that China will increase its nationally determined contribution and adopt a series of more powerful measures to strive for the peak of carbon dioxide emissions by 2030 and strive to achieve carbon neutrality by 2060 . Among the top three countries in Asia, China scores higher in the power generation and forest dimensions, and lower in the carbon emissions and energy consumption dimensions. The main reason why China scores high in the power generation dimension is that China is vigorously developing nuclear power, hydropower, wind power and solar photovoltaic power generation. Meanwhile, the Philippines scores high in carbon emissions and energy consumption, but it scores very low in power generation, and its performance in the forest dimension is average. The economic foundation of the Philippines is relatively weak. Although it has maintained rapid growth from 2010 to 2018, the economic 


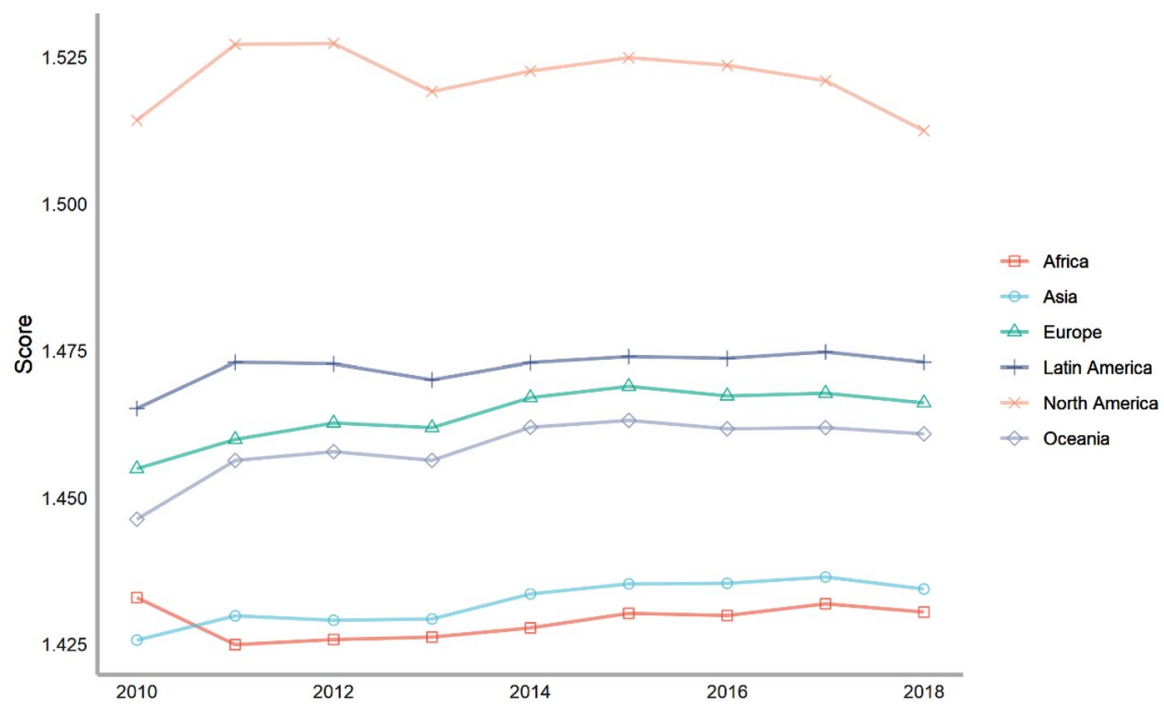

Fig. 2 The score of climate change across continents, 2010-2018

structure of the Philippines is dominated by the service industry, so its industrial and manufacturing capabilities are not strong. Service-oriented economies tend to have relatively low carbon emissions and energy consumption, so the Philippines performs better in these two dimensions. Japan's scores on carbon emissions and energy consumption are slightly lower than those of the Philippines, and its scores on the forest dimension are better However, its score in the power generation dimension has shown a clear downward trend. As mentioned above, this is mainly because nuclear power generation has been greatly affected in Japan. Japan is a major manufacturing country in Asia and the world, with strong demand for energy and electricity. Although the leak at the Fukushima nuclear power plant caused the Japanese people to strongly resist nuclear power generation, Japan currently does not have the ability to completely get rid of nuclear power generation. ${ }^{5}$ As a kind of clean energy, nuclear power generation is gradually recovering in Japan, which will help Japan better achieve its emission reduction targets.

In 2018, we found that the Asian countries ranked at the bottom were Qatar, Kazakhstan and Saudi Arabia. Qatar and Saudi Arabia are desert countries in the Middle East, and Kazakhstan is a landlocked country in Central Asia. These three countries are very rich in oil and natural gas resources, and exporting energy is an important pillar of their own economy. Affected by economic inertia and inherent interests, the three countries have relatively negative attitudes towards the development of new energy sources and are less active in responding to climate change. In addition, the three countries have relatively few forest resources, and as a result their capacity for carbon neutrality is comparatively insufficient. These countries should

\footnotetext{
${ }^{5}$ Kingston (2013).
} 
actively adapt to the requirements of the climate change era, reduce their dependence on fossil energy and actively open up new economic development paths to promote the transition of their entire societies and economies to low carbon.

Europe In 2018, we found that the top three European countries were Sweden, Russia, and France. Sweden and France are major economic powers in Europe, with relatively strong technological and industrial capabilities. In contrast, Russia's economy is heavily dependent on the export trade of oil and natural gas and other resources, and its level of industrialization is relatively weak. The reason why Sweden, Russia and France can rank highly is mainly because they have an outstanding performance in certain dimensions. For example, Sweden scores relatively highly in the carbon emissions, energy consumption and forest dimensions, but it scores poorly in the power generation dimension; Russia scores very highly in the forest dimension, mainly due to its vast territory and high forest coverage. Russia also scores relatively highly in the dimensions of carbon emissions and energy consumption. Although Russia is a major producer and exporter of oil and natural gas, Russia's own manufacturing industry is underdeveloped, and its own carbon emissions and energy consumption are smaller than those of some developed countries. Russia has made slow progress in the development of renewable energy, with a slightly lower score in the power generation dimension. France has a higher score in the carbon emissions and energy consumption dimensions, which is inseparable from France's active transition to a low-carbon economy. It is a developed country and a role model in this area. However, France has a low score in the power generation and forest dimensions, especially in the use of renewable energy to generate electricity. France is not in a leading position.

In 2018, we found that the bottom three countries in Europe were Iceland, Ukraine and the Netherlands. Both Iceland and the Netherlands are developed countries. Iceland's ranking lags behind other European countries because of its poor performance in power generation, carbon emissions and energy consumption. Iceland is located in the northern part of Europe where the climate is relatively cold, and economic activities require a lot of energy consumption and produce a lot of greenhouse gas emissions. However, Iceland has a "bright spot" in power generation: its hydropower and geothermal power generation systems are relatively developed. Iceland's hydropower performance is included in our research, but its performance in geothermal power generation is currently not included, which has somewhat dragged down Iceland's ranking.

The Netherlands ranked 60th in climate in 2018, and its performance in the two dimensions of energy consumption and forests was poor. The Netherlands has a concentration of energy and emission-intensive industries and is heavily dependent on fossil fuels. The academic community is paying increasing attention to how the Netherlands is responding to climate change. ${ }^{6}$ From 2008 to 2018, the share of fossil fuels in the total primary energy supply only slightly decreased, from 92 to $90 \%$. The Netherlands is the most economically developed country in the world, and its

\footnotetext{
${ }^{6}$ Verhoeven, I. (2020). Contentious governance around climate change measures in the Netherlands. Environmental Politics, online first.
} 
current performance in tackling climate change is unsatisfactory. The Dutch government is taking a series of measures to promote a cost-effective transition to a low-carbon economy. One of these measures will result in at least $70 \%$ of electricity coming from renewable energy sources (mainly wind energy and photovoltaic power generation). In addition, the Netherlands has a forest coverage rate of $11 \%$, and the per capita forest area is low (only 0.02 hectares/person), so in the future it is also necessary to improve its performance in the forest dimension. Ukraine is a large agricultural country and has always been known as the "granary of Europe." Because agricultural activities are greatly affected by climate change, the issue of global warming has gradually attracted the attention of Ukrainians. However, Ukraine's economic activities rely heavily on fossil energy and its energy efficiency is low, which has caused Ukraine's poor performance in carbon emissions and power generation. Ukraine is very interested in the use of renewable energy, especially in the application of power generation, and is actively promoting the development of photovoltaic power generation projects.

North America In 2018, Canada's ranking was better than that of the United States. This was mainly due to the Canadian government's long-term continued attention to climate change issues. Canada's only shortcoming is in power generation, especially in the use of renewable energy for power generation. Although the United States is the most economically developed country in the world and has the strongest scientific and technological strength, it is not the most outstanding in addressing the climate change issue. During the Obama administration, the United States not only signed the Paris Climate Agreement, but also actively promoted the development and use of renewable energy. However, the U.S. Republican Party, especially the Trump administration, is skeptical of climate change and has a negative attitude towards climate change. ${ }^{7}$

Latin America In 2018, we found that the top countries in Latin America were Brazil and Peru, and the bottom countries were Argentina and Trinidad and Tobago. Brazil ranks first not only in Latin America, but also in the entire group of 75 countries, as discussed above. It is worth noting that Brazil's virgin rainforest is decreasing. Studies have found that compared with the Democratic Congo and Indonesia, which also have tropical rainforests, Brazil's virgin forest has been reduced by twice that of Indonesia and five times that of the Democratic Republic of Congo. ${ }^{8}$ The reason why Peru ranks highly is that Peru performs very well in the three dimensions of energy consumption, carbon emissions and forests. Argentina is one of the more economically developed countries in Latin America, with relatively developed industry and agriculture and relatively large carbon emissions. Argentina's support for renewable energy is relatively small, and the performance in renewable energy power generation is poor. Trinidad and Tobago is an island country whose economy is dominated by energy development and processing industries, and its ability to cope with climate change is insufficient, so it ranks at the bottom among Latin American countries.

\footnotetext{
7 Selby (2019).

8 Turubanova et al. (2018).
} 
Africa Among the 75 selected countries, only Morocco, Egypt, Algeria and South Africa are in Africa, and their rankings are relatively low. Compared with countries on other continents, the performance of African countries in dealing with climate change is relatively poor and they are more vulnerable to the negative effects of climate change. ${ }^{9}$ The reason is that although the carbon emissions of African countries are generally small, their energy use efficiency is generally low, and their performance in the two dimensions of power generation and forests is also relatively poor. Morocco ranks highly in Africa because it scores highly in the dimensions of carbon emissions and energy consumption, which does not mean that Morocco's economic activities are very focused on improving energy efficiency. The main reason is that Morocco's economic pillars are tourism and fisheries, and industry and manufacturing are underdeveloped. South Africa ranks behind because it is the largest economy in Africa, with relatively developed industrial and manufacturing sectors, and relatively large carbon emissions.

Oceania In 2018, New Zealand and Australia in Oceania ranked 26th and 47th, respectively, with New Zealand performing much better than Australia. Both New Zealand and Australia performed relatively well in terms of carbon emissions and energy consumption, but their performance in the two dimensions of forests and power generation was not satisfactory. In particular, Australia has been performing poorly in forest resource protection. The annual wildfires burn down and devour a large amount of forest, resulting in a negative rate of change in Australia's forest cover. Global warming continues to pose a threat to Australia's forests, and more forest resources may be destroyed in the future. Australia needs to show greater determination to work with the rest of the world to cope with the challenges brought about by climate change.

\subsubsection{Conclusion}

The need to deal with the challenges brought about by climate change is urgent. Countries around the world should strengthen cooperation and strive to achieve the long-term goal set in the Paris Agreement, that is, to control the global average temperature rise to within $2{ }^{\circ} \mathrm{C}$ compared with the pre-industrial period, and efforts should be made to limit the temperature rise to within $1.5^{\circ} \mathrm{C}$. To achieve this goal, more and more countries have adopted various measures to increase their nationally determined contributions. For example, China has made a clear commitment to achieve a peak in carbon emissions by 2030 and carbon neutrality by 2060 . Our research has found that countries around the world currently differ greatly in their capacity to deal with climate change issues. This difference is also reflected in their nationally determined contributions. ${ }^{10}$ Some countries, as represented by China, have the ability to increase their national independent contributions, but most developing countries urgently need support and assistance from developed countries in terms of

\footnotetext{
9 Collier et al. (2008).

10 Mills-Novoa \& Liverman (2019).
} 
capital, technology and science and technology. In particular, African countries need the support of developed countries.

There is also a certain degree of differentiation within developed countries. Some countries have taken a leading position in the development of renewable energy, while the pace of some developed countries has been relatively slow. The Biden administration announced its return to the "Paris Agreement" as soon as it took office. This is a very positive signal for the world's response to climate change. With the support of world powers such as China and the United States, we can expect the world to cooperate closely on the issue of climate change.

\subsection{Issue 2: Peacekeeping}

\subsubsection{Introduction}

War and peace have always accompanied the development of human civilization. Once a war breaks out, justice disappears. Although there has been no major global war since the end of World War II, local conflicts have not ceased and have intensified in some places. Regional conflicts surrounding resources, borders, ethnic conflicts, historical disputes and other factors have always been important factors threatening regional security and development. There can be no justice without security. Therefore, resolving regional conflicts is a long-term focus of the international community, as well as a difficulty and challenge. After World War II, the United Nations came into being. Maintaining peace, preventing and resolving conflicts and wars are important goals of the United Nations. Since the mid-twentieth century, peacekeeping operations have become an important task of the international community, and especially of the United Nations. More and more countries are sending military personnel to participate in UN peacekeeping operations. Some countries provide large amounts of financial support to maintain the smooth progress of UN peacekeeping operations. After the end of the Cold War, United Nations peacekeeping operations have become an important means of regional conflict management and resolution and have received extensive attention and support globally.

The content and scope of peacekeeping work has undergone great changes from the mid-twentieth century to today. ${ }^{11}$ Our understanding of peacekeeping is constantly deepening. The traditional understanding is that peacekeeping work is mainly related to regional security issues, but now peacekeeping work also involves human rights protection, the establishment of the rule of law- and the organization of elections. While UN peacekeeping operations have produced good results, we also find that the willingness and ability of countries to participate in UN peacekeeping is undergoing great changes. In the early days of the rise of peacekeeping, Western developed countries were the most important participating countries. In the following decades, developing countries continued to join the peacekeeping work and gradually grew into the backbone of the UN peacekeeping work. Although

11 Lipson (2007). 
Table 3 Data on peacekeeping

\begin{tabular}{lllll}
\hline Category & Dimension & Indicator & Data source & Coverage \\
\hline Contribution & Personnel Contribution & Troops and Police & UN Peacekeeping & $129(2010-2018)$ \\
& Financial Contribution & Donation & Website & International Peace \\
& & & Institute & \\
& & & & \\
& & &
\end{tabular}

developed countries are still actively participating in UN peacekeeping operations, the number of personnel dispatched shows a clear downward trend. Our research analyzes the contributions of countries around the world to UN peacekeeping operations over the past few years. This is conducive to analyzing the changing trends in UN peacekeeping operations and provides a reference for the future reform and development of UN peacekeeping.

\subsubsection{Dimensions and Indicators}

In general, there are two types of peacekeeping missions. The first type of peacekeeping mission is conducted by the United Nations (UN) and the second is conducted by various regional organizations. Both types of peacekeeping activity are important, but scholars and policy analysts have different opinions on each of them. ${ }^{12}$ In general, more people support peacekeeping operations conducted by the United Nations. The reason is obvious. The United Nations enjoys compelling, overwhelming and incomparable authority in peacekeeping. The peacekeeping efforts of regional organization enjoy certain advantages, but they cannot be comparable to the UN peacekeeping in terms of authority and capacity. In addition, UN peacekeeping data are available online with detailed information about countries' contributions in various ways. Regional peacekeeping data are not fully open source data (Table 3).

As such, our empirical analysis of countries' contributions to peacekeeping is limited to UN peacekeeping contributions. It includes two dimensions: personnel contribution and financial contribution. Personnel contribution is measured by the troops and police indicator, while the financial contribution is measured by the donation indicator. These data are all available on the UN peacekeeping website and international Peace Institute. Our time span is from 2010 to 2018. In the future, we may consider including regional peacekeeping contributions to our analysis.

\subsubsection{Results}

In this section, we present the ranking results of countries' contributions to global justice from a peacekeeping perspective (Table 4). Table 4 shows nine years of results from 2010 to 2018 in 192 countries.

12 Bara \& Hultman (2020). 
The above table shows that from 2010 to 2018, countries such as the United States, Ethiopia, Bangladesh, Rwanda, India, China, Pakistan, Nepal, Japan*, and France have consistently performed well in peacekeeping. Among them, Ethiopia, Bangladesh, Rwanda, India, China, Pakistan and Nepal are all developing countries, while the United States, Japan and France are developed countries. Among them, the United States, China and France are permanent members of the Security Council. Judging from the performance of the top ten, developing countries perform better than developed countries in peacekeeping. This result shows that the degree of economic development itself may not be the main factor influencing the country's participation in UN peacekeeping. Among the top ten countries, six countries are in Asiad, one country is in North America, one country is in Europe, no country is in Latin America, two countries are in Africa, and no country is in Oceania. From the perspective of geographical distribution, Asian countries have contributed more to peacekeeping than other continents.

The United States has long been ranked No. 1 for its contribution to peacekeeping, and it is a model for developed countries' contribution to UN peacekeeping. The United States is a permanent member of the United Nations Security Council and the most powerful country in the world. It has also played the role of "world police" for a long time. The number of peacekeepers (military and police) sent by the United States used to be large, but the number of peacekeepers has gradually decreased over the past few years. At the same time, the United States has increased its financial support for UN peacekeeping. Although the number of peacekeepers dispatched by the United States is decreasing, financial support for peacekeeping has been increasing, which has resulted in the United States ranking first in peacekeeping. In fact, not only is the United States gradually reducing the number of peacekeepers it dispatches, but other developed countries are also reducing the number of peacekeepers they dispatch. The reason why developed countries choose to reduce personnel dispatch and increase financial support is likely to be related to the fact that domestic public opinion is very concerned about casualties among peacekeepers. ${ }^{13}$

Ethiopia is a country with relatively large economic strength, land area and population in Africa. In the past 9 years, Ethiopia's contribution to UN peacekeeping has jumped to second place in the world. The main reason behind this is that Ethiopia is greatly increasing the number of peacekeeping personnel. Taking 2018 as an example, Ethiopia was the country that sent the most peacekeepers. The situation in Bangladesh, India, Pakistan and China is similar to that of Ethiopia. They have all gradually increased their numbers of peacekeeping personnel. This also shows the strong willingness of these countries to support UN peacekeeping. France is a European country that has long performed well in peacekeeping contributions. On the one hand, France is a permanent member of the UN Security Council, and it has assumed the responsibility of maintaining world peace. On the other hand, France has historically been inextricably linked with African countries, especially with its former colonies. France itself, therefore, has a strong need to ensure stability of the

\footnotetext{
13 https://www.passblue.com/2019/02/12/why-developing-nations-send-so-many-troops-to-un-peaceops/.
} 
Table 4 Country ranking in the peacekeeping aspect of promoting global justice

\begin{tabular}{|c|c|c|c|c|c|c|c|c|c|}
\hline Country & 2010 & 2011 & 2012 & 2013 & 2014 & 2015 & 2016 & 2017 & 2018 \\
\hline United States of America & 1 & 1 & 1 & 1 & 1 & 1 & 1 & 1 & 1 \\
\hline Ethiopia & 19 & 15 & 5 & 5 & 5 & 3 & 2 & 2 & 2 \\
\hline Bangladesh & 3 & 2 & 2 & 2 & 2 & 2 & 5 & 4 & 3 \\
\hline Rwanda & 13 & 13 & 8 & 7 & 6 & 6 & 7 & 7 & 4 \\
\hline India & 4 & 4 & 4 & 4 & 3 & 5 & 3 & 3 & 5 \\
\hline China & 11 & 12 & 7 & 9 & 8 & 7 & 6 & 6 & 6 \\
\hline Pakistan & 2 & 3 & 3 & 3 & 4 & 4 & 4 & 5 & 7 \\
\hline Nepal & 9 & 9 & 11 & 8 & 7 & 8 & 8 & 8 & 8 \\
\hline Egypt & 6 & 7 & 10 & 14 & 15 & 20 & 14 & 10 & 9 \\
\hline Japan & 7 & 6 & 9 & 10 & 10 & 9 & 10 & 11 & 10 \\
\hline France & 8 & 8 & 12 & 12 & 11 & 10 & 13 & 12 & 11 \\
\hline Germany & 16 & 16 & 16 & 17 & 17 & 16 & 19 & 15 & 12 \\
\hline Indonesia & 23 & 23 & 23 & 23 & 26 & 15 & 15 & 13 & 13 \\
\hline Ghana & 14 & 17 & 14 & 13 & 12 & 12 & 11 & 14 & 14 \\
\hline United Republic of Tanzania & 32 & 27 & 26 & 21 & 19 & 22 & 18 & 18 & 15 \\
\hline Senegal & 20 & 21 & 19 & 16 & 13 & 11 & 9 & 9 & 16 \\
\hline $\begin{array}{l}\text { United Kingdom of Great Britain and } \\
\text { Northern Ireland }\end{array}$ & 15 & 14 & 17 & 18 & 18 & 17 & 20 & 17 & 17 \\
\hline Italy & 10 & 11 & 15 & 15 & 14 & 14 & 17 & 19 & 18 \\
\hline Burkina Faso & 34 & 30 & 32 & 27 & 22 & 19 & 12 & 16 & 19 \\
\hline Morocco & 24 & 24 & 24 & 24 & 21 & 21 & 22 & 20 & 20 \\
\hline Chad & 89 & 89 & 88 & 40 & 33 & 34 & 26 & 23 & 21 \\
\hline Togo & 38 & 41 & 40 & 28 & 27 & 25 & 23 & 24 & 22 \\
\hline Spain & 18 & 18 & 22 & 25 & 28 & 27 & 28 & 22 & 23 \\
\hline Republic of Korea & 25 & 25 & 25 & 29 & 30 & 31 & 31 & 27 & 24 \\
\hline Russian Federation & 28 & 32 & 29 & 32 & 34 & 35 & 30 & 26 & 25 \\
\hline South Africa & 22 & 22 & 21 & 20 & 20 & 23 & 24 & 25 & 26 \\
\hline Cameroon & 76 & 76 & 72 & 80 & 29 & 18 & 32 & 31 & 27 \\
\hline Zambia & 37 & 45 & 63 & 70 & 75 & 50 & 39 & 32 & 28 \\
\hline Mauritania & 179 & 179 & 140 & 138 & 93 & 74 & 40 & 33 & 29 \\
\hline Niger & 45 & 38 & 30 & 26 & 25 & 24 & 21 & 29 & 30 \\
\hline Canada & 26 & 26 & 28 & 33 & 79 & 86 & 36 & 35 & 31 \\
\hline Uruguay & 17 & 20 & 20 & 19 & 24 & 29 & 27 & 28 & 32 \\
\hline Malawi & 68 & 42 & 35 & 41 & 40 & 40 & 37 & 37 & 33 \\
\hline Guinea & 86 & 87 & 90 & 73 & 67 & 46 & 42 & 38 & 34 \\
\hline Mongolia & 50 & 80 & 45 & 35 & 36 & 39 & 38 & 34 & 35 \\
\hline Malaysia & 30 & 29 & 27 & 34 & 37 & 41 & 43 & 40 & 36 \\
\hline Jordan & 12 & 10 & 13 & 11 & 16 & 26 & 33 & 39 & 37 \\
\hline Benin & 27 & 33 & 34 & 30 & 31 & 30 & 29 & 36 & 38 \\
\hline Cambodia & 80 & 61 & 57 & 52 & 43 & 42 & 44 & 42 & 39 \\
\hline Burundi & 88 & 79 & 77 & 69 & 47 & 32 & 35 & 41 & 40 \\
\hline Netherlands & 39 & 40 & 42 & 46 & 35 & 33 & 41 & 43 & 41 \\
\hline Australia & 36 & 35 & 39 & 39 & 42 & 44 & 46 & 44 & 42 \\
\hline
\end{tabular}


Table 4 (continued)

\begin{tabular}{|c|c|c|c|c|c|c|c|c|c|}
\hline Country & 2010 & 2011 & 2012 & 2013 & 2014 & 2015 & 2016 & 2017 & 2018 \\
\hline Sri Lanka & 29 & 28 & 31 & 31 & 32 & 43 & 51 & 49 & 43 \\
\hline Fiji & 60 & 59 & 58 & 48 & 41 & 45 & 47 & 45 & 44 \\
\hline Ireland & 52 & 48 & 43 & 45 & 49 & 52 & 52 & 46 & 45 \\
\hline Sweden & 46 & 49 & 52 & 54 & 53 & 47 & 48 & 47 & 46 \\
\hline Uganda & 66 & 88 & 94 & 93 & 96 & 100 & 49 & 48 & 47 \\
\hline Nigeria & 5 & 5 & 6 & 6 & 9 & 13 & 16 & 21 & 48 \\
\hline Brazil & 21 & 19 & 18 & 22 & 23 & 28 & 25 & 30 & 49 \\
\hline Finland & 59 & 62 & 59 & 51 & 46 & 51 & 54 & 54 & 50 \\
\hline Gabon & 145 & 145 & 146 & 145 & 69 & 53 & 56 & 52 & 51 \\
\hline Argentina & 33 & 31 & 33 & 36 & 38 & 48 & 55 & 50 & 52 \\
\hline Austria & 40 & 39 & 38 & 42 & 50 & 54 & 57 & 55 & 53 \\
\hline Switzerland & 47 & 50 & 54 & 55 & 55 & 57 & 60 & 56 & 54 \\
\hline Belgium & 41 & 44 & 47 & 49 & 52 & 59 & 63 & 63 & 55 \\
\hline Ukraine & 53 & 56 & 46 & 43 & 44 & 49 & 50 & 53 & 56 \\
\hline Norway & 49 & 55 & 56 & 57 & 56 & 56 & 59 & 58 & 57 \\
\hline Saudi Arabia & 64 & 65 & 68 & 68 & 74 & 73 & 66 & 61 & 58 \\
\hline Portugal & 44 & 47 & 53 & 71 & 73 & 71 & 77 & 59 & 59 \\
\hline Greece & 56 & 58 & 61 & 59 & 64 & 65 & 72 & 71 & 60 \\
\hline Serbia & 94 & 91 & 82 & 72 & 66 & 60 & 62 & 60 & 61 \\
\hline Cote d'Ivoire & 69 & 68 & 69 & 60 & 62 & 76 & 124 & 75 & 62 \\
\hline Gambia & 51 & 52 & 50 & 53 & 54 & 61 & 61 & 57 & 63 \\
\hline Peru & 54 & 54 & 49 & 50 & 51 & 62 & 58 & 62 & 64 \\
\hline Slovakia & 62 & 64 & 66 & 64 & 68 & 67 & 71 & 69 & 65 \\
\hline Turkey & 42 & 46 & 41 & 44 & 60 & 66 & 70 & 72 & 66 \\
\hline Tunisia & 58 & 95 & 92 & 67 & 76 & 69 & 65 & 65 & 67 \\
\hline El Salvador & 79 & 82 & 83 & 79 & 83 & 72 & 69 & 68 & 68 \\
\hline Denmark & 48 & 51 & 62 & 62 & 63 & 63 & 67 & 64 & 69 \\
\hline Kenya & 35 & 36 & 37 & 37 & 39 & 36 & 34 & 66 & 70 \\
\hline Djibouti & 98 & 96 & 95 & 74 & 72 & 75 & 75 & 74 & 71 \\
\hline Guatemala & 57 & 57 & 60 & 58 & 59 & 64 & 68 & 70 & 72 \\
\hline United Arab Emirates & 71 & 70 & 67 & 66 & 71 & 70 & 74 & 73 & 73 \\
\hline Congo & 149 & 160 & 156 & 159 & 58 & 38 & 45 & 51 & 74 \\
\hline Israel & 67 & 69 & 71 & 76 & 78 & 78 & 78 & 76 & 75 \\
\hline Singapore & 70 & 71 & 73 & 78 & 82 & 84 & 79 & 77 & 76 \\
\hline Mexico & 65 & 67 & 75 & 77 & 81 & 81 & 83 & 80 & 77 \\
\hline Czechia & 90 & 84 & 76 & 81 & 84 & 85 & 82 & 82 & 78 \\
\hline Zimbabwe & 75 & 75 & 85 & 82 & 89 & 92 & 85 & 85 & 79 \\
\hline New Zealand & 74 & 74 & 79 & 85 & 87 & 90 & 86 & 87 & 80 \\
\hline Liberia & 179 & 179 & 163 & 103 & 97 & 97 & 95 & 91 & 81 \\
\hline Sierra Leone & 61 & 53 & 51 & 65 & 80 & 89 & 88 & 84 & 82 \\
\hline Hungary & 73 & 73 & 74 & 75 & 77 & 79 & 81 & 81 & 83 \\
\hline Poland & 77 & 78 & 78 & 84 & 85 & 87 & 87 & 88 & 84 \\
\hline
\end{tabular}


Table 4 (continued)

\begin{tabular}{|c|c|c|c|c|c|c|c|c|c|}
\hline Country & 2010 & 2011 & 2012 & 2013 & 2014 & 2015 & 2016 & 2017 & 2018 \\
\hline Kuwait & 84 & 83 & 84 & 88 & 91 & 93 & 89 & 89 & 85 \\
\hline Romania & 78 & 81 & 80 & 83 & 86 & 82 & 80 & 83 & 86 \\
\hline Chile & 43 & 43 & 44 & 47 & 48 & 55 & 53 & 67 & 87 \\
\hline Qatar & 93 & 93 & 87 & 90 & 94 & 94 & 91 & 90 & 88 \\
\hline Namibia & 87 & 86 & 89 & 94 & 88 & 91 & 92 & 96 & 89 \\
\hline Mali & 81 & 77 & 81 & 87 & 90 & 88 & 90 & 93 & 90 \\
\hline Croatia & 72 & 72 & 70 & 91 & 104 & 104 & 108 & 108 & 91 \\
\hline Estonia & 111 & 108 & 108 & 108 & 110 & 98 & 94 & 92 & 92 \\
\hline Thailand & 82 & 37 & 48 & 96 & 99 & 80 & 97 & 99 & 93 \\
\hline Slovenia & 92 & 90 & 91 & 95 & 98 & 96 & 98 & 97 & 94 \\
\hline Bhutan & 191 & 191 & 192 & 185 & 150 & 112 & 103 & 100 & 95 \\
\hline Bosnia and Herzegovina & 101 & 100 & 96 & 92 & 95 & 99 & 99 & 98 & 96 \\
\hline Brunei Darussalam & 105 & 97 & 99 & 99 & 105 & 102 & 102 & 101 & 97 \\
\hline Lithuania & 119 & 116 & 119 & 117 & 116 & 121 & 120 & 116 & 98 \\
\hline Armenia & 155 & 153 & 142 & 144 & 125 & 103 & 101 & 103 & 99 \\
\hline Venezuela (Bolivarian Republic of) & 102 & 104 & 97 & 98 & 103 & 101 & 104 & 104 & 100 \\
\hline Paraguay & 83 & 66 & 65 & 63 & 70 & 77 & 76 & 78 & 101 \\
\hline Iran (Islamic Republic of) & 106 & 106 & 103 & 104 & 109 & 110 & 105 & 106 & 102 \\
\hline Oman & 114 & 112 & 100 & 100 & 106 & 106 & 106 & 105 & 103 \\
\hline Kazakhstan & 118 & 120 & 116 & 121 & 124 & 115 & 111 & 112 & 104 \\
\hline Colombia & 95 & 99 & 98 & 97 & 101 & 107 & 96 & 95 & 105 \\
\hline Philippines & 31 & 34 & 36 & 38 & 45 & 68 & 73 & 86 & 106 \\
\hline Bolivia (Plurinational State of) & 55 & 63 & 64 & 61 & 65 & 83 & 107 & 94 & 107 \\
\hline Kyrgyzstan & 104 & 107 & 105 & 101 & 107 & 111 & 110 & 109 & 108 \\
\hline Madagascar & 91 & 92 & 93 & 89 & 102 & 108 & 100 & 107 & 109 \\
\hline Luxembourg & 96 & 98 & 102 & 102 & 108 & 109 & 109 & 110 & 110 \\
\hline Samoa & 112 & 117 & 110 & 112 & 112 & 116 & 113 & 111 & 111 \\
\hline Viet Nam & 133 & 133 & 133 & 133 & 136 & 127 & 121 & 121 & 112 \\
\hline Cyprus & 107 & 105 & 106 & 107 & 111 & 113 & 112 & 113 & 113 \\
\hline Latvia & 126 & 126 & 127 & 126 & 132 & 130 & 126 & 123 & 114 \\
\hline Honduras & 115 & 113 & 112 & 113 & 100 & 95 & 93 & 102 & 115 \\
\hline Ecuador & 85 & 85 & 86 & 86 & 92 & 105 & 114 & 119 & 116 \\
\hline Bahrain & 113 & 111 & 113 & 114 & 118 & 119 & 116 & 118 & 117 \\
\hline Algeria & 116 & 110 & 111 & 110 & 114 & 118 & 115 & 114 & 118 \\
\hline Libya & 99 & 101 & 109 & 111 & 115 & 114 & 117 & 120 & 119 \\
\hline Republic of Moldova & 121 & 118 & 118 & 115 & 119 & 120 & 118 & 124 & 120 \\
\hline Cuba & 125 & 124 & 128 & 127 & 133 & 131 & 132 & 117 & 121 \\
\hline Belarus & 129 & 125 & 120 & 116 & 122 & 124 & 122 & 122 & 122 \\
\hline Bulgaria & 124 & 122 & 121 & 122 & 126 & 126 & 127 & 126 & 123 \\
\hline Iraq & 141 & 139 & 129 & 128 & 134 & 132 & 123 & 127 & 124 \\
\hline Dominican Republic & 129 & 127 & 132 & 130 & 131 & 136 & 134 & 115 & 125 \\
\hline Iceland & 108 & 109 & 115 & 118 & 121 & 123 & 125 & 128 & 126 \\
\hline
\end{tabular}


Table 4 (continued)

\begin{tabular}{|c|c|c|c|c|c|c|c|c|c|}
\hline Country & 2010 & 2011 & 2012 & 2013 & 2014 & 2015 & 2016 & 2017 & 2018 \\
\hline Montenegro & 128 & 123 & 122 & 123 & 127 & 133 & 129 & 129 & 127 \\
\hline Costa Rica & 132 & 132 & 138 & 137 & 142 & 141 & 139 & 130 & 128 \\
\hline Solomon Islands & 179 & 179 & 183 & 185 & 186 & 186 & 143 & 132 & 129 \\
\hline Malta & 122 & 119 & 124 & 124 & 129 & 128 & 128 & 131 & 130 \\
\hline Yemen & 63 & 60 & 55 & 56 & 61 & 58 & 64 & 79 & 131 \\
\hline Trinidad and Tobago & 120 & 115 & 117 & 119 & 123 & 125 & 131 & 134 & 132 \\
\hline Papua New Guinea & 165 & 156 & 145 & 140 & 151 & 144 & 129 & 137 & 133 \\
\hline Bahamas & 123 & 121 & 125 & 125 & 130 & 129 & 132 & 135 & 134 \\
\hline Azerbaijan & 146 & 142 & 135 & 135 & 140 & 138 & 136 & 136 & 135 \\
\hline Democratic Republic of the Congo & 109 & 102 & 104 & 109 & 57 & 37 & 84 & 125 & 136 \\
\hline Central African Republic & 100 & 94 & 101 & 106 & 117 & 135 & 186 & 133 & 137 \\
\hline Monaco & 146 & 142 & 130 & 129 & 135 & 134 & 138 & 138 & 138 \\
\hline Lebanon & 133 & 133 & 133 & 133 & 138 & 137 & 140 & 139 & 139 \\
\hline Myanmar & 161 & 160 & 156 & 159 & 161 & 147 & 135 & 143 & 140 \\
\hline Panama & 140 & 138 & 141 & 142 & 147 & 148 & 141 & 141 & 141 \\
\hline Andorra & 131 & 131 & 135 & 135 & 140 & 138 & 142 & 142 & 142 \\
\hline Turkmenistan & 136 & 135 & 147 & 146 & 152 & 150 & 145 & 144 & 143 \\
\hline Republic of North Macedonia & 142 & 140 & 143 & 143 & 149 & 149 & 148 & 147 & 144 \\
\hline Syrian Arab Republic & 138 & 136 & 139 & 139 & 145 & 143 & 146 & 145 & 145 \\
\hline Uzbekistan & 152 & 150 & 149 & 149 & 155 & 154 & 147 & 146 & 146 \\
\hline Tajikistan & 117 & 114 & 114 & 105 & 120 & 164 & 162 & 163 & 147 \\
\hline Cabo Verde & 168 & 168 & 171 & 173 & 170 & 168 & 175 & 156 & 148 \\
\hline Barbados & 139 & 137 & 148 & 148 & 154 & 153 & 152 & 150 & 149 \\
\hline San Marino & 146 & 142 & 149 & 149 & 155 & 154 & 151 & 149 & 150 \\
\hline Botswana & 143 & 141 & 123 & 147 & 153 & 151 & 152 & 150 & 151 \\
\hline Mauritius & 150 & 149 & 151 & 152 & 158 & 157 & 154 & 153 & 152 \\
\hline Jamaica & 103 & 103 & 107 & 120 & 113 & 117 & 144 & 152 & 153 \\
\hline Albania & 97 & 130 & 153 & 155 & 143 & 142 & 156 & 154 & 154 \\
\hline Georgia & 154 & 152 & 154 & 157 & 159 & 156 & 137 & 140 & 154 \\
\hline Suriname & 161 & 160 & 161 & 164 & 165 & 162 & 157 & 155 & 156 \\
\hline Angola & 155 & 153 & 156 & 159 & 161 & 159 & 158 & 158 & 157 \\
\hline Democratic People's Republic of Korea & 153 & 151 & 155 & 158 & 160 & 158 & 158 & 158 & 157 \\
\hline Eritrea & 179 & 179 & 183 & 185 & 186 & 186 & 186 & 186 & 157 \\
\hline Timor-Leste & 179 & 165 & 126 & 141 & 137 & 140 & 155 & 162 & 157 \\
\hline Vanuatu & 110 & 179 & 183 & 151 & 128 & 122 & 119 & 167 & 157 \\
\hline Nicaragua & 161 & 160 & 164 & 166 & 167 & 164 & 162 & 163 & 162 \\
\hline Afghanistan & 165 & 166 & 166 & 168 & 169 & 167 & 165 & 165 & 163 \\
\hline Antigua and Barbuda & 158 & 157 & 161 & 164 & 165 & 162 & 165 & 165 & 163 \\
\hline Eswatini & 161 & 160 & 164 & 166 & 167 & 164 & 168 & 168 & 165 \\
\hline Guyana & 168 & 168 & 171 & 173 & 175 & 174 & 168 & 168 & 165 \\
\hline Maldives & 179 & 179 & 171 & 173 & 175 & 174 & 168 & 168 & 165 \\
\hline Kiribati & 179 & 179 & 183 & 185 & 186 & 186 & 186 & 186 & 168 \\
\hline
\end{tabular}


Table 4 (continued)

\begin{tabular}{|c|c|c|c|c|c|c|c|c|c|}
\hline Country & 2010 & 2011 & 2012 & 2013 & 2014 & 2015 & 2016 & 2017 & 2018 \\
\hline Lesotho & 151 & 148 & 131 & 131 & 139 & 146 & 164 & 186 & 168 \\
\hline Saint Kitts and Nevis & 168 & 168 & 168 & 170 & 170 & 168 & 171 & 171 & 168 \\
\hline Sudan & 155 & 153 & 156 & 159 & 161 & 159 & 158 & 158 & 168 \\
\hline Belize & 168 & 168 & 171 & 173 & 175 & 174 & 175 & 175 & 172 \\
\hline Dominica & 168 & 168 & 171 & 173 & 175 & 174 & 175 & 175 & 172 \\
\hline Grenada & 135 & 128 & 152 & 156 & 146 & 145 & 167 & 175 & 172 \\
\hline Guinea-Bissau & 127 & 129 & 183 & 154 & 148 & 152 & 149 & 148 & 172 \\
\hline Marshall Islands & 168 & 168 & 171 & 173 & 175 & 174 & 175 & 175 & 172 \\
\hline Micronesia (Federated States of) & 168 & 168 & 171 & 173 & 175 & 174 & 175 & 175 & 172 \\
\hline Mozambique & 137 & 147 & 144 & 153 & 157 & 171 & 150 & 157 & 172 \\
\hline Nauru & 168 & 168 & 171 & 173 & 175 & 174 & 175 & 175 & 172 \\
\hline Palau & 144 & 146 & 137 & 132 & 144 & 174 & 175 & 175 & 172 \\
\hline Saint Lucia & 168 & 168 & 171 & 173 & 175 & 174 & 175 & 175 & 172 \\
\hline Saint Vincent and the Grenadines & 168 & 168 & 171 & 173 & 175 & 174 & 175 & 175 & 172 \\
\hline Sao Tome and Principe & 179 & 179 & 183 & 185 & 186 & 186 & 186 & 186 & 172 \\
\hline Seychelles & 158 & 157 & 168 & 170 & 173 & 171 & 175 & 175 & 172 \\
\hline Tonga & 168 & 168 & 171 & 173 & 175 & 174 & 175 & 175 & 172 \\
\hline Equatorial Guinea & 158 & 157 & 156 & 159 & 161 & 159 & 158 & 158 & 186 \\
\hline Haiti & 167 & 167 & 168 & 170 & 173 & 171 & 171 & 171 & 186 \\
\hline Lao People's Democratic Republic & 179 & 179 & 171 & 173 & 175 & 174 & 171 & 171 & 186 \\
\hline Somalia & 179 & 179 & 183 & 185 & 186 & 186 & 186 & 186 & 186 \\
\hline South Sudan & 191 & 191 & 167 & 169 & 170 & 168 & 171 & 171 & 186 \\
\hline Tuvalu & 179 & 179 & 183 & 185 & 186 & 186 & 186 & 186 & 186 \\
\hline Comoros & 179 & 179 & 183 & 185 & 186 & 186 & 186 & 186 & 192 \\
\hline
\end{tabular}

situation in Africa, and because many United Nations peacekeeping operations take place in Africa, naturally France will attach great importance to it.

India's contribution to UN peacekeeping has long ranked among the top 5 in the world. India was one of the earliest countries in the world to participate in UN peacekeeping, and it has always been very active. Some statistics show that India has sent more than 180,000 people to UN peacekeeping operations, making it one of the countries with the largest number of personnel sent to peacekeeping operations. India has also displayed its own characteristics and innovations in participating in UN peacekeeping. For example, in 2007, India became the first country to send an all-female peacekeeping team to a UN peacekeeping operation. Because India has been involved in UN peacekeeping for a long time and has participated in more peacekeeping operations, and because some peacekeeping operations are very dangerous, there has been a relatively large number of casualties in India's 
peacekeeping operations. Statistics show that more than 160 Indian peacekeepers have died in peacekeeping operations. ${ }^{14}$

China used to reject participation in UN peacekeeping operations, but now it has not only become an active participant, but also has made major contributions to participating in UN peacekeeping operations. ${ }^{15}$ In 2012, China became a top ten country for the first time, and further rose to sixth place in 2018. Compared with many developed countries, China's participation in UN peacekeeping operations started relatively late, but the pace of development has been fast. In April 1990, the Chinese army sent five military observers to the UN Truce Supervision Organization. This was the beginning of China's participation in UN peacekeeping operations. As of 2020, China's peacekeeping operations will cover more than 20 countries and regions including Cambodia, Liberia, Congo (Kinshasa), Cyprus, Sudan, Lebanon, South Sudan, Mali and Central Africa. According to the data in the white paper "The Chinese Army's Participation in UN Peacekeeping Operations for 30 Years", the Chinese military has participated in $25 \mathrm{UN}$ peacekeeping operations. As a key force in UN peacekeeping operations, China's role includes six aspects: monitoring ceasefires, stabilizing the situation, protecting civilians, acting as security guards, supporting guarantees and spreading hope. Upholding the concept of "a community with a shared future for mankind", we can expect China to play a greater role in maintaining peace.

The above table shows that from 2010 to 2018, countries such as Laos, Somalia, South Sudan, Tuvalu and Comoros ranked last in terms of peacekeeping performance. These five countries have relatively small territories, relatively small populations, and relatively low levels of economic development. They are typical small countries. In countries such as Somalia and South Sudan, their domestic social order is relatively unstable, with internal ethnic, social and criminal problems emerging one after another. As their domestic problems are still very serious, it is difficult for these countries to make greater contributions to the UN peacekeeping cause. UN peacekeeping work requires financial and personnel technical support. Many small countries often do not have these capabilities and, therefore, cannot make a substantial contribution to UN peacekeeping.

From the data, we can find that the rankings of most countries are relatively stable, but there are also some countries whose rankings have experienced greater fluctuations from 2010 to 2018. For example, Italy's ranking has been gradually declining. Italy is a large European country, which formerly had colonized some countries in Africa, and is thus inextricably linked with Africa. And because Italy and the northern African countries belong to the countries along the Mediterranean Sea, in fact they are "across the sea" from each other, and as such Italy is affected by the impact of African refugees. However, in recent years, with the weakening of the Italian economy and the rise of a populist government in Italy, Italy's willingness and ability to participate in international affairs has gradually declined. During the same period, the rankings of the Philippines, Yemen, Albania, Nigeria and other countries

\footnotetext{
14 https://news.un.org/en/gallery/541602.

15 Hang (2013).
} 
dropped significantly. The reasons for the decline in the ranking of these countries are different. For example, Nigeria's ranking dropped from 5th in 2010 to 48th in 2018. The reason for the decline in ranking is that Nigeria's peacekeeping focus has always been on parts of West Africa. As the security situation in this region continues to improve, Nigeria has gradually reduced its peacekeeping forces. ${ }^{16}$ The ranking of the Philippines has gradually dropped from 31st in 2010 to 106th in 2018. The purpose of sending peacekeepers by the Philippines is to advance national interests and better participate in international military cooperation. Satisfying the needs of national interests is the primary reason. The Philippines tends to send peacekeepers to areas where there are more Filipinos overseas in accordance with the needs of the United Nations. This is because a large number of Filipino workers working overseas are sending money to their home country as an important source of income for the Philippines. Instability in some areas will affect the work of Filipino workers in these places and directly affect their remittances to their home country. ${ }^{17}$

From 2010 to 2018, we found that Chad, Mauritania, Guyana, Cambodia, Gabon, Congo, Liberia and other countries have greatly increased their rankings. For example, Gabon's ranking in peacekeeping rose from 145th in 2010 to 51 st in 2018. Congo's ranking in peacekeeping rose from 149th in 2010 to 74th in 2018. The countries that have risen sharply in these rankings are basically African countries and especially Central and West African countries. These African countries have increased their support for United Nations peacekeeping operations in the past few years and in particular have actively participated in peacekeeping operations in some areas of Africa. Among them, the most typical is the participation of countries such as Chad, Gabon, and Congo in the UN peacekeeping operations in the Central African Republic. The Central African Republic has been in a state of civil war since 2012. The government forces and the rebel coalition "Séléka" have been in a state of ongoing conflict. ${ }^{18}$ Because the conflict in Central Africa still shows no sign of ending, these African countries may continue to be at the forefront of the ranking.

\subsubsection{Regional Analysis}

In 2018, the top 10 countries in the field of peacekeeping were the following: the United States, Ethiopia, Bangladesh, Rwanda, India, China, Pakistan, Nepal, Egypt and Japan (Fig. 3). Among the top 10 countries, there is 1 American country, plus 6 Asian countries, and 3 African countries. No European country made the top 10. There are eight developing countries and two developed countries. This shows that the degree of economic development is not necessarily related to participation in UN peacekeeping. Both developed and developing countries have the opportunity and ability to play an important role in participating in UN peacekeeping. In fact, from the perspective of the top 10 selected countries, the contribution of developing

\footnotetext{
16 Hamman \& Omojuwa (2013).

17 Philippine Participation in UN Peace Operations. https://www.fsi.gov.ph/wp-content/uploads/2019/08/ 2015-Special-Issue-No-2-May-FSI-Insights-UN-Peace-Operations.pdf.

18 For more information about Séléka, see Kah (2013).
} 


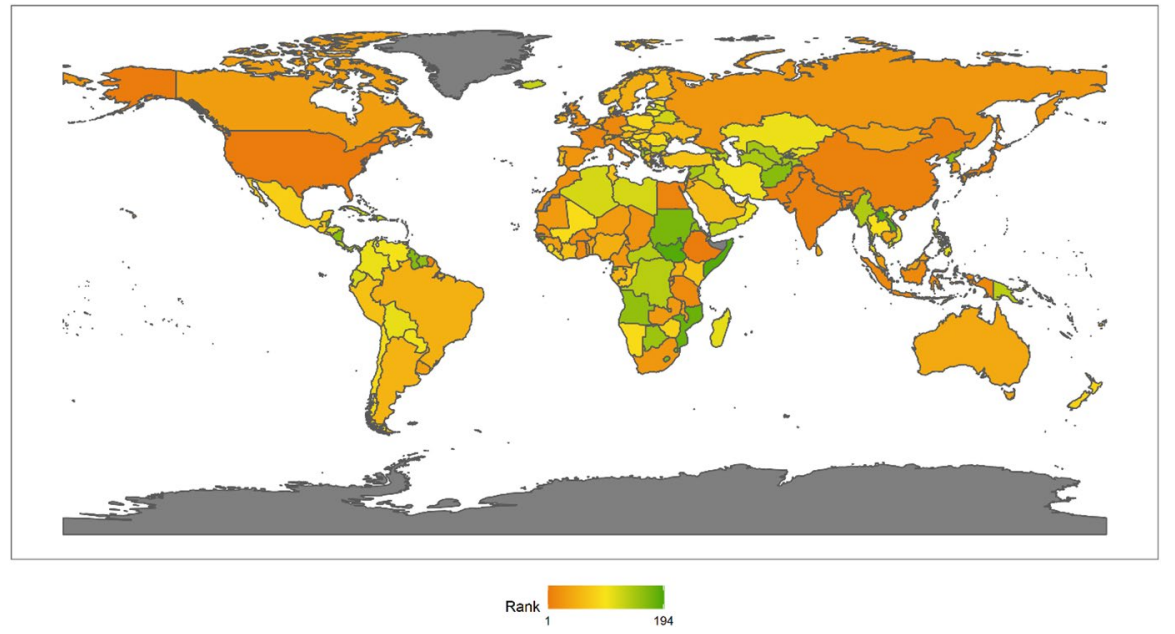

Fig. 32018 Index ranking of peacekeeping on a world map

countries to the cause of UN peacekeeping may be greater than that of developed countries.

The above-mentioned countries are able to rank highly in the field of peacekeeping because they have some common characteristics. First, these countries are generally concerned about the international and regional security situation. Needless to say, the United States has long played the role of "world police". China and Japan are also very concerned about the international and regional security situation. China has always cherished a peaceful international and regional environment, because China's development cannot be separated from world peace. Second, the military capabilities of these countries are generally relatively strong. United Nations peacekeeping contributions are mainly personnel contributions and financial contributions. At present, personnel contributions are the core part. Sending troops and police to UN peacekeeping operations has certain requirements for the military capabilities of the sending country. United Nations peacekeeping operations are highly dangerous and peacekeepers are likely to be involved in local armed conflicts. United Nations peacekeepers sent by countries with stronger military capabilities can better deal with complex local political and military risks. Third, these countries aspire to play a more important role in international and regional affairs. The United States, China, India and Japan are all major countries with global influence, and have been very active in global governance. The United States and China are permanent members of the UN Security Council, and it is their responsibility to actively participate in peacekeeping operations. India and Japan have always sought to be among the permanent members of the UN Security Council, so they are very enthusiastic about participating in UN peacekeeping.

Next, we also classify countries according to their continents. These continents include Asia, Europe, North America, Latin America, Africa and Oceania. The ranking of each continent is obtained by calculating the average of the rankings of 


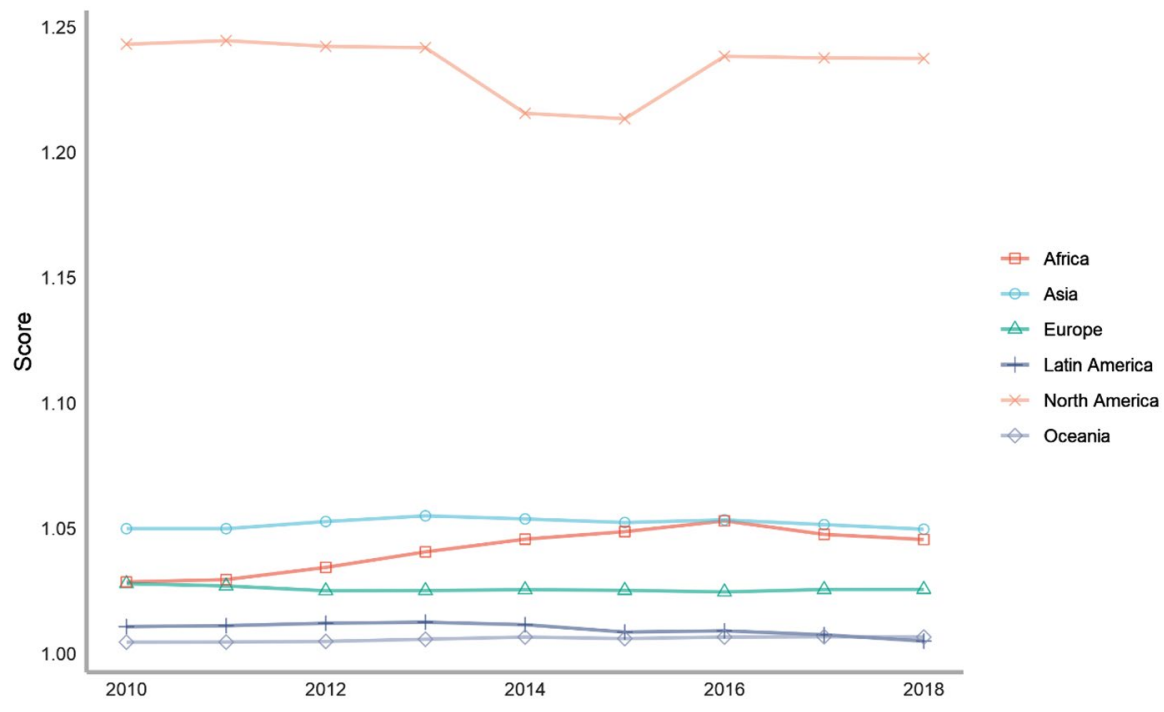

Fig. 4 The score of peacekeeping across continents, 2010-2018

these countries. We drew a line chart to achieve a visual presentation to compare the differences in the contribution of each continent in peacekeeping (Fig. 4).

From the above figure, we can find that taking 2018 as an example, in terms of participating in UN peacekeeping, if we compare the average performance of countries on each continent, North American countries have contributed the most, followed by Asian and African countries and finally Latin American and Oceanian countries. North American countries only include the United States and Canada, which have performed very well in peacekeeping. African countries as a whole have also made relatively large contributions to peacekeeping. This is partly because many peacekeeping operations have taken place on African territory. Compared with other continents, Latin America and Oceania are at the bottom of the ranking. Latin American countries rank lower mainly because some island countries in Central America tend to have lower rankings; while Oceanian countries rank at the bottom because both the large countries in the region (Australia and New Zealand) and small Oceanian countries generally lag behind in their peacekeeping contribution rankings.

Asia In 2018, we found that the top 5 Asian countries are Bangladesh, India, China, Pakistan and Nepal, and the bottom countries are North Korea, Afghanistan, the Maldives, Micronesia and Laos. China and India are the top countries in the Asian region in terms of comprehensive national strength and are the two most populous countries among all developing countries. India was one of the earliest countries to participate in peacekeeping among all Asian countries, and it has consistently maintained this relatively high enthusiasm for participation. It is unexpected that Bangladesh ranks No. 1 in Asia. Bangladesh has a population of over 100 million, but its level of economic and social development is low, and nearly half of the population lives below the poverty line. Bangladesh has participated in UN 
peacekeeping work since the 1980s and has become the largest source of UN peacekeeping forces in this century. ${ }^{19}$ There are many reasons why Bangladesh actively participates in UN peacekeeping. On the one hand, this can greatly improve Bangladesh's regional and global reputation. On the other hand, Bangladesh can also receive a large amount of financial compensation. These funds can be used in all aspects of the country's construction in addition to paying for the soldiers killed and wounded in peacekeeping missions. Obtaining some financial assistance through participating in UN peacekeeping is a very important reason for developing countries to participate in peacekeeping. ${ }^{20}$ Pakistan ranks highly in the field of peacekeeping, and even ranked second in the world in 2010. Pakistan and India are hostile to each other, and the foreign policies of the two countries are highly targeted at each other. Because India is actively participating in global peacekeeping operations to expand its influence, Pakistan also has the motivation to strengthen its influence in UN peacekeeping operations. ${ }^{21}$ Similar to Bangladesh, Pakistan's participation in UN peacekeeping operations is also motivated by financial returns. In the peacekeeping rankings of Asian countries, the countries that lag behind are often small and relatively closed countries. North Korea is a closed country and has not been involved in global and regional security affairs for a long time. Therefore, it is reasonable for it not to actively participate in the UN peacekeeping work. The Maldives, Micronesia and Laos are all small Asian countries, and their own capabilities limit their participation in UN peacekeeping operations.

Europe In 2018, we found that the top five European countries are France, Germany, the United Kingdom, Italy and Spain, and the bottom countries are Morocco, Andorra, North Macedonia and Albania. France and the United Kingdom are permanent members of the UN Security Council, and they themselves shoulder responsibility for maintaining global and regional security. Active participation in UN peacekeeping is a long-term foreign policy of France and the United Kingdom. Germany caused tremendous damage to global security in the Second World War. After the end of World War II, Germany adopted a diplomatic and security strategy of "hiding our power and biding our time" and did not actively participate in the work of the United Nations. It was not until the 1990s that Germany began to gradually participate in UN peacekeeping operations. Germany is a country with a large number of military and police contributions among developed countries, which notable as many developed countries are now gradually reducing the number of people they discharge. Germany is the fourth largest United Nations' dues-paying country and has made a great financial contribution to UN peacekeeping. ${ }^{22}$ Another important reason why Germany has strengthened its contribution to UN peacekeeping is that it hopes to become a permanent member of the Security Council. At this point, the situation in Germany is similar to that of Japan and India. Britain once ranked higher than Germany in terms of peacekeeping, but in recent years Britain

\footnotetext{
19 Zaman, \& Biswas, (2014).

${ }^{20}$ Coleman \& Nyblade (2018).

21 Kathman, \& Melin, (2017).

22 https://www.deutschland.de/zh-hans/topic/zhengzhi/weihepinggongtongnuli.
} 
has begun to implement an "isolationist" policy. Britain's contribution to peacekeeping is on a downward trend, which is basically consistent with Britain's departure from the European Union. Morocco, Andorra, North Macedonia and Albania, which rank at the bottom, are all small European countries with a small population and a relatively small land area. They have long pursued a policy of partial security and are not actively participating in global governance.

North America The United States is a permanent member of the UN Security Council. It has long regarded itself as a "world policeman", and its active participation in UN peacekeeping is in line with this. On the other hand, the United States has a unique practical advantage in participating in UN peacekeeping. A large number of US defense funds are used to maintain various military bases outside the United States. According to incomplete statistics, the United States has more than 800 military bases in approximately 70 countries and regions. The existence of these military bases helps the United States keep abreast of the security situation and the latest trends in various countries and regions around the world. ${ }^{23}$ These resources are a huge supporting force for the United States' participation in UN peacekeeping. In recent years, the United States' financial support for UN peacekeeping has been continuously increasing, while its contribution to UN personnel has gradually weakened. This is consistent with the performance of many other developed countries in UN peacekeeping. Canada is a developed country with a large area and a sparse population. Although it has a small population, it has always been a country with a global perspective. Canada participated in UN peacekeeping operations relatively early on. In the 1960s, participation in UN peacekeeping even became a part of Canada's national identity, a responsibility and contribution that Canadians are proud of. Although the peacekeeping "fever" gradually subsided in Canada due to scandals and other reasons, Canada is still an important participant in UN peacekeeping.

Latin America In 2018, we found that the top three Latin American countries were Uruguay, Brazil and Argentina. The bottom countries are Grenada, Dominica, Saint Lucia, Saint Vincent and the Grenadines and Haiti. Brazil and Argentina are the most important countries in South America, and it is not surprising that they are at the forefront of the UN peacekeeping rankings. Compared with Brazil and Argentina, Uruguay is a very small country. Uruguay has a population of just over 3 million, and its territory is the second smallest in Latin America, after Suriname. However, this relatively small country ranks much higher than Brazil and Argentina in terms of UN peacekeeping. There are many reasons why Uruguay ranks first in Latin America.

First of all, Uruguay has a relatively sound economic foundation, and its per capita GDP has long ranked first in Latin America. Second, Uruguay's peacekeeping capabilities have received assistance and support from the United States. Finally, Uruguay has a relatively long experience in participating in UN peacekeeping and has become one of the countries with the largest number of military and police contributions per capita to UN peacekeeping. The countries at the bottom are mainly small countries in Central America. These countries have small populations, low

23 Davis (2011). 
economic and social standards and severely inadequate national capabilities. Some of these countries are themselves destination countries for UN peacekeeping. A typical country in this regard is Haiti. For example, the United Nations Stabilization Mission in Haiti was established in Haiti in 2004 and only ended in 2017. The lack of national capabilities restricts these countries from playing a greater role in UN peacekeeping.

Africa In 2018, we found that the top five African countries are Ethiopia, Rwanda, Egypt, Ghana and Tanzania, and the bottom countries are Guinea-Bissau, Equatorial Guinea, South Sudan, Somalia and Comoros. Ethiopia is the most populous landlocked country in the world and the second most populous country in Africa. Ethiopia has participated in UN peacekeeping operations since the 1950s and has continued to do so to this day. At present, Ethiopia has become the country that has contributed the most to UN peacekeeping in terms of numbers. This is also the main reason why it can rank second in the world for its contribution to UN peacekeeping. Rwanda is a small country in Africa with a very small area. Rwanda experienced a terrible genocide in the 1990s, and is a country in which UN peacekeeping operations have also intervened. Rwanda has participated in UN peacekeeping operations since 2005. Although it started relatively late, it developed rapidly. Now Rwanda has become one of the countries that provides the most personnel support for UN peacekeeping - a very striking performance. Egypt began to participate in UN peacekeeping work in the 1960s, and today has become one of the countries with the largest number of military and police contributions. Egypt has participated in all of the UN peacekeeping projects in Africa, which shows that Egypt attaches great importance to its role in Africa's security and stability. Ghana is a country in western Africa. Ghana began to participate in UN peacekeeping work in the 1970s, and has since increased the number of military and police dispatched, and as a result its contribution to peacekeeping has gradually increased. Tanzania is a country in eastern Africa. Tanzania has a large population, but its level of economic and social development is low. Nevertheless, Tanzania's ranking in the field of peacekeeping has been on the rise. The African countries at the bottom are Guinea-Bissau, Equatorial Guinea, South Sudan, Somalia and Comoros. These countries have relatively small populations and relatively small land areas, and their economic and social development levels are at the middle and lower levels, even for Africa. Moreover, the internal social security and stability situation of some countries is severe, and there are many domestic contradictions. These factors limit their willingness and ability to participate in UN peacekeeping operations.

Oceania In 2018, we found that the top three countries in Oceania are Australia, Fiji and New Zealand. The bottom countries are Tuvalu, Palau and Tonga. Australia and New Zealand are the two largest countries in Oceania, and both are developed countries. These two countries were among the first countries to participate in the UN peacekeeping work, and have made great contributions to the development of the UN peacekeeping cause. However, in recent years, the rankings of these two countries in the field of peacekeeping have shown a downward trend. The main reason is that the number of military and police personnel sent by them has declined. In contrast, Fiji's ranking in the field of peacekeeping has improved significantly. Fiji is a small country in Oceania with a population of less than one million and a 
very small land area. Despite being a small country, Fiji has become a model for participation during its 40-year history of participating in UN peacekeeping. By per capita standards, Fiji has been the country with the most UN peacekeepers since the 1970s. Tuvalu, Palau and Tonga are all Pacific island countries, and their own national capabilities are not enough to make a significant contribution to UN peacekeeping, so they rank very low.

\subsubsection{Conclusion}

World peace is a common aspiration of the whole world and this is also inherent to the topic of promoting global justice. United Nations peacekeeping operations are an important means of maintaining peace and reducing wars, and they have achieved good results over the past few decades. At the same time, great changes have taken place in the types, methods and scope of countries participating in UN peacekeeping. Although the United States is the country that has contributed the most to participating in UN peacekeeping, the number of personnel sent is far lower than that of developing countries such as Ethiopia and Bangladesh. Developing countries are increasingly emerging as the backbone of UN peacekeeping operations. From the comparison of various continents, except for the outstanding performance of North America, the overall performance of other continents is almost the same. This shows that participation in peacekeeping is not necessarily related to a country's wealth, population and geographic location. It may be related to the country's will, the country's interests and the country's security environment. Today's world is still not at peace, and various regional conflicts occur one after another. UN peacekeeping operations will not only continue, but may also expand. This requires more countries to be willing to strengthen their support for UN peacekeeping operations. This support can be carried out in the form of increased peacekeeping funds or in the form of additional peacekeepers. No matter what form it takes, this is an important contribution to world peace and global justice.

\subsection{Issue 3: Humanitarian Aid}

\subsubsection{Introduction}

Humanitarian aid denotes the short-term assistance provided in response to natural disasters and emergencies. In recent years, international organizations are gradually building consensus about the guidelines and principles regarding humanitarian aid in both theoretical and practical respects. For example, the International Code of Medical Ethics asserts that doctors "are duty-bound to provide technically competent care, treat patients with compassion, and respect human dignity", and the Geneva Conventions of 1949 proposed an international humanitarian law with the principles of humanity, neutrality, impartiality and independence. ${ }^{24}$ Providing help

${ }^{24}$ Zarka et al. (2019). 
to save lives, reduce suffering and maintain human dignity is a vital aspect of the global justice agenda. As a result, we included this issue into our global justice index and measure each country's efforts to provide humanitarian aid by evaluating their financial contribution to global humanitarian affairs.

\subsubsection{Dimensions and Indicators}

Last year, we used ten indicators to measure each country's efforts toward humanitarian aid. These ten indicators are food, health, water, emergency response, early recovery, coordination, education, protection, agriculture and other. The last indicator, "other," denotes donations without a designated use. This year, we added the sector of "housing" into the measurement, with the other scores unchanged; thus there are 11 indicators in all. We included humanitarian donations from each country to UN departments, nongovernmental organizations and other relevant organizations such as the World Food Program, the World Health Organization (WHO) and the International Federation of Red Cross and Red Crescent Societies. We also include the one-to-one donations from one nation state directly to another nation state. Data are obtained from the Financial Tracking Service database, managed by the UN Office for the Coordination of Humanitarian Affairs. It "aims to present a complete picture of all international humanitarian funding flows" such that it "supports the transparency and accountability of the humanitarian system and facilitates resource mobilization." 25 Please see below the details of all the indicators in the measurement of humanitarian aid (Table 5).

In contrast to our measurement of other issues, here we sum up the amount of donations to the 11 indicators to obtain a total number and use GDP per capita to control for the impact of economic size. The underlying principle is that countries with rich resources and big economies have stronger financial strength to provide humanitarian aid, and it is not reasonable to compare the contributions of big and small countries by the same criteria.

\subsubsection{Results}

According to the results, the Unites States performs excellently on the issue of humanitarian aid (Table 6). It has maintained first place from 2010 to 2018. Rich countries in Asia such as Saudi Arabia and the United Arab Emirates contributed greatly as well. European countries ranked at the forefront generally.

The United States donated more than 7 billion dollars in 2018. Most of this (more than 2 billion) went to the food security sector, followed by the sector of coordination and support services (more than 274 million) and the health sector (more than 154 million). Saudi Arabia donated more than 1 billion dollars in 2018, with most of this going to the coordination and support services and food security sector. The United Arab Emirates donated more than 2 billion dollars in 2018, with most of this going to the food security sector and the health sector. The United Kingdom donated

${ }_{25}$ Please check https://fts.unocha.org/content/about-fts-1 for more information about FTS. 
Table 5 Indicators of humanitarian aid

\begin{tabular}{llll}
\hline Issue Area & Indicator & Source & Coverage \\
\hline Humanitarian Aid & Food & Financial Tracking Service & 181 \\
& housing & & $(2010-2018)$ \\
& Health & & \\
Water & & \\
& Emergency Response & \\
& Early Recovery & \\
& Coordination & \\
& Education & & \\
& Protection & \\
& Agriculture & \\
& Other & \\
\hline
\end{tabular}

more than 1 billion dollars in 2018, with most of this going to the food security sector and the health sector. Germany donated more than 2 billion dollars in 2018, the majority of which went to the food security sector. Canada donated more than 500 million dollars in 2018, with most of this going to the food security sector and the health sector. Through the analysis of the financial flows of the top contributors in 2018 , it is obvious that most of the humanitarian aid worldwide is used to ensure food provision and fight hunger.

Although there are many of organizations, programs and initiatives relating to food assistance in the world, the major way for national states to provide food aid is through the World Food Programme (WFP). The WFP is initiated by the UN and works through the UN system. It is "the leading humanitarian organization saving lives and changing lives, delivering food assistance in emergencies and working with communities to improve nutrition and build resilience." ${ }^{26}$ More specifically, support from the WFP consists of the following three categories: food assistance supplied directly to families or individuals; food support supplied directly to national stakeholders (governments or civil society); and South-South and triangular cooperation, which focuses on the exchange of experience, knowledge, cash or other forms of assistance between developing countries. ${ }^{27}$ The latest strategic goals of the WFP are the Sustainable Development Goals set forth in the 2030 Agenda, which aims to transform lives to an unprecedented level by 2030 (Fig. 5).

The top ten countries in the provision of humanitarian aid in 2018 are the United States, Saudi Arabia, the United Arab Emirates, the United Kingdom, Germany, Canada, Kuwait, Japan and Sweden. The United States performed excellently in humanitarian aid and has consistently ranked at the top from 2010 to 2018. Arab countries with strong petroleum reserves, such as Saudi Arabia and the United Arab Emirates, contributed greatly on this issue as well. European countries ranked at the

\footnotetext{
${ }^{26}$ https://www.wfp.org/overview.

27 https://www.wfp.org/types-of-support.
} 
Table 6 Country ranking in humanitarian aid

\begin{tabular}{|c|c|c|c|c|c|c|c|c|c|}
\hline Country & 2010 & 2011 & 2012 & 2013 & 2014 & 2015 & 2016 & 2017 & 2018 \\
\hline United States of America & 1 & 1 & 1 & 1 & 1 & 1 & 1 & 1 & 1 \\
\hline Saudi Arabia & 4 & 12 & 3 & 7 & 3 & 6 & 6 & 4 & 2 \\
\hline United Arab Emirates & 26 & 17 & 30 & 14 & 11 & 8 & 7 & 12 & 3 \\
\hline $\begin{array}{l}\text { United Kingdom of Great Britain } \\
\text { and Northern Ireland }\end{array}$ & 3 & 5 & 2 & 2 & 2 & 3 & 3 & 3 & 4 \\
\hline Germany & 15 & 9 & 6 & 4 & 5 & 4 & 2 & 2 & 5 \\
\hline Canada & 12 & 10 & 8 & 6 & 9 & 10 & 8 & 6 & 6 \\
\hline Kuwait & 60 & 48 & 43 & 8 & 12 & 5 & 11 & 11 & 7 \\
\hline Japan & 5 & 8 & 4 & 3 & 6 & 7 & 5 & 5 & 8 \\
\hline Sweden & 9 & 7 & 7 & 5 & 8 & 12 & 10 & 9 & 9 \\
\hline Pakistan & 105 & 30 & 10 & 65 & 7 & 2 & 4 & 8 & 10 \\
\hline Norway & 17 & 15 & 11 & 9 & 15 & 15 & 9 & 14 & 11 \\
\hline Afghanistan & 22 & 91 & 75 & 74 & 100 & 85 & 92 & 79 & 12 \\
\hline Denmark & 21 & 19 & 20 & 10 & 13 & 16 & 12 & 13 & 13 \\
\hline Belgium & 28 & 23 & 16 & 12 & 19 & 17 & 15 & 15 & 14 \\
\hline Netherlands & 20 & 21 & 12 & 15 & 14 & 11 & 13 & 20 & 15 \\
\hline Burundi & 47 & 110 & 99 & 87 & 100 & 94 & 92 & 79 & 16 \\
\hline Italy & 30 & 31 & 27 & 22 & 23 & 24 & 16 & 18 & 17 \\
\hline Switzerland & 24 & 22 & 15 & 11 & 17 & 19 & 18 & 19 & 18 \\
\hline Niger & 136 & 110 & 99 & 87 & 100 & 94 & 22 & 10 & 19 \\
\hline Australia & 19 & 16 & 17 & 13 & 20 & 26 & 17 & 21 & 20 \\
\hline Sudan & 13 & 18 & 99 & 87 & 100 & 94 & 92 & 79 & 21 \\
\hline France & 14 & 24 & 19 & 21 & 18 & 21 & 14 & 16 & 22 \\
\hline Republic of Korea & 42 & 38 & 33 & 29 & 29 & 31 & 29 & 28 & 23 \\
\hline Finland & 32 & 26 & 21 & 17 & 22 & 25 & 20 & 26 & 24 \\
\hline China & 8 & 6 & 13 & 23 & 16 & 20 & 21 & 7 & 25 \\
\hline Ireland & 38 & 32 & 26 & 19 & 26 & 29 & 27 & 29 & 26 \\
\hline Spain & 11 & 11 & 24 & 18 & 25 & 28 & 31 & 27 & 27 \\
\hline Russian Federation & 23 & 28 & 18 & 20 & 24 & 23 & 26 & 30 & 28 \\
\hline Qatar & 102 & 51 & 29 & 26 & 27 & 30 & 35 & 32 & 29 \\
\hline Austria & 51 & 44 & 41 & 37 & 51 & 42 & 34 & 33 & 30 \\
\hline Brazil & 27 & 33 & 14 & 42 & 33 & 33 & 43 & 37 & 31 \\
\hline New Zealand & 52 & 36 & 40 & 38 & 45 & 39 & 39 & 35 & 32 \\
\hline Nigeria & 41 & 39 & 99 & 87 & 37 & 49 & 62 & 22 & 33 \\
\hline Luxembourg & 49 & 45 & 39 & 35 & 44 & 41 & 36 & 39 & 34 \\
\hline South Africa & 79 & 34 & 49 & 47 & 52 & 48 & 46 & 40 & 35 \\
\hline Turkey & 18 & 14 & 32 & 33 & 35 & 34 & 41 & 25 & 36 \\
\hline Estonia & 85 & 64 & 52 & 43 & 59 & 47 & 45 & 41 & 37 \\
\hline Mexico & 40 & 57 & 53 & 51 & 43 & 64 & 38 & 51 & 38 \\
\hline Poland & 55 & 42 & 38 & 39 & 48 & 40 & 33 & 31 & 39 \\
\hline Bangladesh & 33 & 84 & 57 & 87 & 100 & 37 & 81 & 23 & 40 \\
\hline Czechia & 64 & 50 & 44 & 41 & 54 & 38 & 40 & 38 & 41 \\
\hline Bulgaria & 93 & 76 & 59 & 49 & 77 & 58 & 51 & 49 & 42 \\
\hline
\end{tabular}


Table 6 (continued)

\begin{tabular}{|c|c|c|c|c|c|c|c|c|c|}
\hline Country & 2010 & 2011 & 2012 & 2013 & 2014 & 2015 & 2016 & 2017 & 2018 \\
\hline Slovakia & 90 & 110 & 64 & 60 & 86 & 66 & 50 & 50 & 43 \\
\hline Indonesia & 37 & 47 & 36 & 31 & 40 & 36 & 58 & 48 & 44 \\
\hline Kazakhstan & 31 & 37 & 58 & 46 & 49 & 35 & 48 & 56 & 45 \\
\hline Iceland & 115 & 89 & 84 & 56 & 80 & 62 & 55 & 46 & 46 \\
\hline Belarus & 67 & 61 & 46 & 44 & 66 & 50 & 47 & 47 & 47 \\
\hline Argentina & 122 & 90 & 69 & 58 & 79 & 94 & 68 & 44 & 48 \\
\hline Lithuania & 97 & 87 & 85 & 69 & 72 & 57 & 53 & 55 & 49 \\
\hline Philippines & 98 & 35 & 22 & 30 & 32 & 75 & 59 & 17 & 50 \\
\hline Thailand & 35 & 69 & 82 & 50 & 38 & 27 & 66 & 42 & 51 \\
\hline Portugal & 87 & 85 & 66 & 59 & 64 & 60 & 67 & 63 & 52 \\
\hline Romania & 100 & 70 & 54 & 53 & 69 & 52 & 56 & 60 & 53 \\
\hline Colombia & 29 & 102 & 63 & 45 & 67 & 61 & 82 & 57 & 54 \\
\hline Malaysia & 73 & 88 & 77 & 61 & 62 & 56 & 77 & 43 & 55 \\
\hline Malta & 112 & 67 & 86 & 72 & 78 & 71 & 61 & 54 & 56 \\
\hline Myanmar & 114 & 63 & 71 & 63 & 85 & 72 & 74 & 62 & 57 \\
\hline Slovenia & 94 & 68 & 80 & 66 & 84 & 68 & 65 & 52 & 58 \\
\hline Cote d'Ivoire & 136 & 95 & 37 & 87 & 42 & 78 & 92 & 66 & 59 \\
\hline Monaco & 121 & 97 & 87 & 77 & 87 & 77 & 79 & 65 & 60 \\
\hline Azerbaijan & 53 & 53 & 48 & 54 & 58 & 43 & 92 & 53 & 61 \\
\hline Costa Rica & 129 & 110 & 99 & 87 & 98 & 94 & 92 & 79 & 62 \\
\hline Latvia & 120 & 81 & 79 & 67 & 73 & 65 & 80 & 79 & 63 \\
\hline Algeria & 36 & 20 & 99 & 36 & 93 & 94 & 49 & 72 & 64 \\
\hline Mongolia & 117 & 49 & 99 & 71 & 91 & 82 & 92 & 71 & 65 \\
\hline Central African Republic & 54 & 110 & 99 & 87 & 4 & 94 & 37 & 79 & 66 \\
\hline Chile & 125 & 86 & 81 & 64 & 71 & 63 & 76 & 67 & 67 \\
\hline Iraq & 44 & 27 & 99 & 24 & 28 & 51 & 84 & 79 & 68 \\
\hline Cyprus & 113 & 80 & 78 & 78 & 94 & 84 & 85 & 73 & 69 \\
\hline Montenegro & 131 & 79 & 92 & 81 & 95 & 94 & 90 & 79 & 70 \\
\hline Sri Lanka & 107 & 46 & 28 & 62 & 55 & 76 & 92 & 61 & 71 \\
\hline Armenia & 101 & 101 & 62 & 79 & 76 & 86 & 83 & 76 & 72 \\
\hline Singapore & 119 & 99 & 90 & 80 & 83 & 70 & 71 & 68 & 73 \\
\hline Andorra & 118 & 96 & 89 & 76 & 89 & 80 & 86 & 75 & 74 \\
\hline Bhutan & 132 & 107 & 95 & 87 & 100 & 45 & 92 & 77 & 75 \\
\hline Guyana & 58 & 73 & 96 & 83 & 74 & 90 & 88 & 79 & 76 \\
\hline Namibia & 134 & 43 & 99 & 86 & 50 & 94 & 92 & 79 & 77 \\
\hline Grenada & 111 & 110 & 99 & 87 & 100 & 94 & 92 & 79 & 77 \\
\hline Chad & 50 & 72 & 99 & 87 & 100 & 13 & 92 & 79 & 77 \\
\hline Mali & 136 & 110 & 99 & 87 & 63 & 94 & 92 & 79 & 77 \\
\hline Peru & 83 & 110 & 91 & 73 & 97 & 89 & 87 & 74 & 77 \\
\hline Palau & 136 & 110 & 99 & 87 & 100 & 94 & 92 & 79 & 77 \\
\hline Trinidad and Tobago & 91 & 110 & 99 & 87 & 96 & 69 & 92 & 79 & 77 \\
\hline India & 2 & 4 & 25 & 16 & 10 & 22 & 30 & 36 & 77 \\
\hline
\end{tabular}


Table 6 (continued)

\begin{tabular}{|c|c|c|c|c|c|c|c|c|c|}
\hline Country & 2010 & 2011 & 2012 & 2013 & 2014 & 2015 & 2016 & 2017 & 2018 \\
\hline Antigua and Barbuda & 124 & 110 & 99 & 87 & 100 & 74 & 92 & 79 & 77 \\
\hline Djibouti & 126 & 110 & 94 & 84 & 100 & 91 & 89 & 79 & 77 \\
\hline Tuvalu & 136 & 110 & 99 & 87 & 100 & 94 & 92 & 79 & 77 \\
\hline Israel & 123 & 94 & 72 & 87 & 56 & 94 & 92 & 79 & 77 \\
\hline Cameroon & 136 & 110 & 99 & 87 & 100 & 55 & 92 & 79 & 77 \\
\hline Zimbabwe & 136 & 110 & 9 & 87 & 100 & 94 & 28 & 79 & 77 \\
\hline San Marino & 127 & 103 & 97 & 87 & 99 & 93 & 92 & 78 & 77 \\
\hline Angola & 136 & 40 & 99 & 87 & 30 & 94 & 92 & 79 & 77 \\
\hline Malawi & 136 & 110 & 5 & 87 & 100 & 14 & 92 & 79 & 77 \\
\hline Bolivia (Plurinational State of) & 136 & 110 & 99 & 87 & 41 & 94 & 92 & 79 & 77 \\
\hline Libya & 136 & 110 & 99 & 87 & 100 & 94 & 92 & 79 & 77 \\
\hline Maldives & 136 & 83 & 99 & 87 & 100 & 94 & 92 & 79 & 77 \\
\hline United Republic of Tanzania & 136 & 93 & 42 & 87 & 100 & 94 & 92 & 79 & 77 \\
\hline Morocco & 10 & 100 & 47 & 25 & 36 & 46 & 92 & 79 & 77 \\
\hline Dominican Republic & 43 & 110 & 99 & 87 & 100 & 94 & 63 & 79 & 77 \\
\hline Guatemala & 136 & 110 & 99 & 87 & 100 & 94 & 92 & 79 & 77 \\
\hline Belize & 136 & 110 & 99 & 87 & 100 & 94 & 92 & 79 & 77 \\
\hline Congo & 56 & 52 & 99 & 87 & 100 & 94 & 92 & 79 & 77 \\
\hline Ghana & 34 & 110 & 70 & 87 & 100 & 94 & 92 & 79 & 77 \\
\hline Sierra Leone & 63 & 110 & 99 & 87 & 100 & 94 & 25 & 79 & 77 \\
\hline El Salvador & 136 & 110 & 99 & 87 & 100 & 94 & 92 & 79 & 77 \\
\hline Samoa & 136 & 75 & 99 & 87 & 100 & 94 & 70 & 79 & 77 \\
\hline Mauritania & 136 & 110 & 99 & 32 & 100 & 94 & 92 & 79 & 77 \\
\hline Papua New Guinea & 136 & 110 & 99 & 87 & 100 & 94 & 57 & 79 & 77 \\
\hline Botswana & 99 & 82 & 65 & 68 & 81 & 94 & 75 & 59 & 77 \\
\hline Saint Kitts and Nevis & 136 & 110 & 99 & 87 & 100 & 67 & 92 & 79 & 77 \\
\hline Mauritius & 82 & 110 & 74 & 87 & 92 & 53 & 92 & 79 & 77 \\
\hline Gambia & 39 & 110 & 99 & 87 & 100 & 94 & 92 & 79 & 77 \\
\hline Burkina Faso & 59 & 110 & 99 & 87 & 100 & 94 & 92 & 79 & 77 \\
\hline Lesotho & 136 & 110 & 99 & 87 & 100 & 94 & 32 & 79 & 77 \\
\hline Ukraine & 57 & 110 & 60 & 87 & 100 & 94 & 92 & 79 & 77 \\
\hline Jamaica & 136 & 110 & 99 & 87 & 100 & 94 & 92 & 79 & 77 \\
\hline Honduras & 136 & 110 & 99 & 87 & 100 & 94 & 92 & 79 & 77 \\
\hline Zambia & 136 & 110 & 55 & 87 & 100 & 94 & 92 & 79 & 77 \\
\hline Saint Lucia & 104 & 109 & 99 & 87 & 100 & 94 & 92 & 79 & 77 \\
\hline Haiti & 136 & 110 & 99 & 87 & 100 & 94 & 92 & 79 & 77 \\
\hline Hungary & 88 & 71 & 50 & 48 & 61 & 54 & 42 & 45 & 77 \\
\hline Democratic Republic of the Congo & 16 & 62 & 34 & 87 & 57 & 94 & 19 & 79 & 77 \\
\hline Turkmenistan & 77 & 110 & 99 & 87 & 100 & 94 & 92 & 79 & 77 \\
\hline Cuba & 80 & 110 & 56 & 87 & 100 & 94 & 92 & 79 & 77 \\
\hline Lao People's Democratic Republic & 136 & 66 & 99 & 55 & 100 & 94 & 92 & 79 & 77 \\
\hline Tonga & 136 & 74 & 99 & 87 & 100 & 94 & 92 & 79 & 77 \\
\hline
\end{tabular}


Table 6 (continued)

\begin{tabular}{|c|c|c|c|c|c|c|c|c|c|}
\hline Country & 2010 & 2011 & 2012 & 2013 & 2014 & 2015 & 2016 & 2017 & 2018 \\
\hline Tunisia & 66 & 110 & 99 & 87 & 100 & 94 & 92 & 79 & 77 \\
\hline Equatorial Guinea & 75 & 110 & 99 & 87 & 100 & 94 & 92 & 79 & 77 \\
\hline Paraguay & 136 & 110 & 99 & 87 & 100 & 94 & 92 & 79 & 77 \\
\hline Bosnia and Herzegovina & 108 & 110 & 99 & 87 & 100 & 94 & 92 & 64 & 77 \\
\hline Seychelles & 136 & 110 & 99 & 87 & 100 & 94 & 92 & 79 & 77 \\
\hline Saint Vincent and the Grenadines & 109 & 110 & 99 & 87 & 100 & 94 & 92 & 79 & 77 \\
\hline Oman & 61 & 110 & 35 & 28 & 34 & 94 & 92 & 79 & 77 \\
\hline Tajikistan & 78 & 54 & 88 & 87 & 100 & 94 & 92 & 79 & 77 \\
\hline Rwanda & 69 & 110 & 99 & 87 & 100 & 94 & 92 & 79 & 77 \\
\hline Uruguay & 136 & 110 & 98 & 85 & 82 & 92 & 92 & 79 & 77 \\
\hline Egypt & 46 & 29 & 76 & 87 & 46 & 94 & 44 & 79 & 77 \\
\hline Micronesia (Federated States of) & 136 & 110 & 99 & 87 & 100 & 94 & 92 & 79 & 77 \\
\hline Serbia & 106 & 108 & 99 & 82 & 100 & 88 & 52 & 79 & 77 \\
\hline Albania & 136 & 105 & 67 & 87 & 100 & 94 & 91 & 79 & 77 \\
\hline Eswatini & 136 & 110 & 99 & 87 & 100 & 94 & 92 & 79 & 77 \\
\hline Republic of Moldova & 96 & 97 & 93 & 87 & 100 & 94 & 92 & 79 & 77 \\
\hline Lebanon & 133 & 110 & 99 & 87 & 100 & 94 & 92 & 79 & 77 \\
\hline Ethiopia & 136 & 3 & 99 & 87 & 100 & 94 & 24 & 34 & 77 \\
\hline Madagascar & 110 & 110 & 99 & 87 & 100 & 94 & 23 & 79 & 77 \\
\hline Kyrgyzstan & 81 & 59 & 99 & 87 & 100 & 94 & 92 & 79 & 77 \\
\hline Jordan & 136 & 110 & 99 & 87 & 100 & 59 & 92 & 79 & 77 \\
\hline Liberia & 84 & 110 & 99 & 87 & 100 & 94 & 92 & 24 & 77 \\
\hline Yemen & 136 & 110 & 99 & 87 & 100 & 94 & 92 & 79 & 77 \\
\hline Nauru & 136 & 110 & 99 & 87 & 100 & 94 & 72 & 79 & 77 \\
\hline Dominica & 136 & 110 & 99 & 87 & 100 & 94 & 69 & 79 & 77 \\
\hline Senegal & 45 & 110 & 99 & 87 & 100 & 94 & 92 & 79 & 77 \\
\hline Cambodia & 89 & 110 & 99 & 87 & 100 & 94 & 92 & 79 & 77 \\
\hline Suriname & 74 & 110 & 99 & 87 & 100 & 94 & 92 & 79 & 77 \\
\hline Bahamas & 65 & 110 & 99 & 87 & 100 & 94 & 92 & 79 & 77 \\
\hline Gabon & 76 & 110 & 99 & 87 & 100 & 94 & 92 & 79 & 77 \\
\hline Panama & 130 & 110 & 99 & 87 & 100 & 94 & 92 & 79 & 77 \\
\hline Uganda & 72 & 110 & 99 & 87 & 100 & 94 & 92 & 79 & 77 \\
\hline Fiji & 136 & 110 & 99 & 87 & 100 & 94 & 92 & 79 & 77 \\
\hline Georgia & 92 & 78 & 99 & 60 & 88 & 73 & 64 & 79 & 77 \\
\hline Ecuador & 136 & 104 & 99 & 87 & 60 & 94 & 60 & 79 & 77 \\
\hline Benin & 70 & 110 & 99 & 87 & 100 & 94 & 92 & 79 & 77 \\
\hline Kenya & 25 & 25 & 23 & 34 & 39 & 94 & 92 & 70 & 77 \\
\hline Viet Nam & 68 & 55 & 73 & 70 & 70 & 79 & 78 & 69 & 77 \\
\hline Nepal & 6 & 2 & 99 & 87 & 100 & 9 & 92 & 79 & 77 \\
\hline Togo & 136 & 110 & 99 & 87 & 90 & 94 & 92 & 79 & 77 \\
\hline Greece & 86 & 58 & 68 & 57 & 65 & 87 & 54 & 58 & 77 \\
\hline Barbados & 136 & 110 & 99 & 87 & 100 & 94 & 92 & 79 & 77 \\
\hline
\end{tabular}


Table 6 (continued)

\begin{tabular}{llllllllll}
\hline Country & 2010 & 2011 & 2012 & 2013 & 2014 & 2015 & 2016 & 2017 & 2018 \\
\hline Mozambique & 116 & 110 & 45 & 75 & 100 & 94 & 92 & 79 & 77 \\
Uzbekistan & 71 & 60 & 99 & 87 & 100 & 94 & 92 & 79 & 77 \\
Republic of North Macedonia & 103 & 110 & 99 & 87 & 100 & 94 & 92 & 79 & 77 \\
Timor-Leste & 48 & 41 & 31 & 87 & 31 & 44 & 92 & 79 & 77 \\
Bahrain & 62 & 56 & 51 & 27 & 47 & 83 & 92 & 79 & 77 \\
Croatia & 95 & 65 & 61 & 52 & 68 & 81 & 73 & 79 & 77 \\
Brunei Darussalam & 128 & 98 & 83 & 87 & 75 & 94 & 92 & 79 & 77 \\
Nicaragua & 136 & 106 & 99 & 87 & 100 & 94 & 92 & 79 & 77 \\
Venezuela (Bolivarian Republic of) & 135 & 77 & 99 & 87 & 53 & NA & NA & NA & NA \\
South Sudan & 136 & 13 & 99 & 40 & 21 & 18 & NA & NA & NA \\
Eritrea & 136 & 110 & NA & NA & NA & NA & NA & NA & NA \\
Iran (Islamic Republic of) & 7 & 92 & 99 & 87 & 100 & 32 & 92 & 79 & NA \\
\hline
\end{tabular}
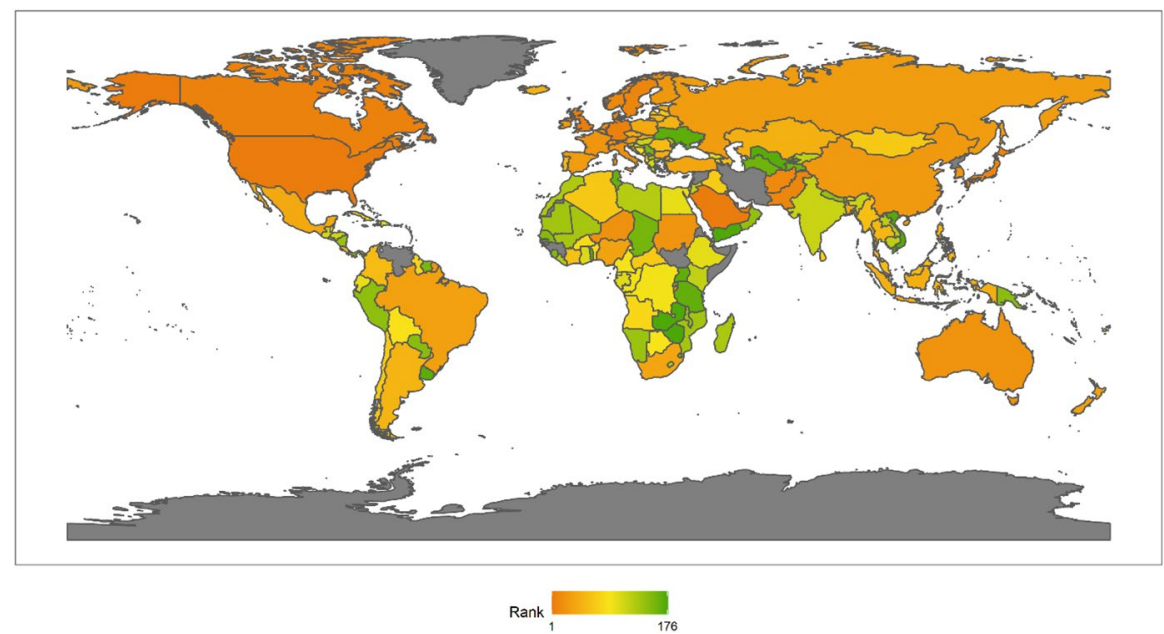

Fig. 52018 Index ranking of humanitarian aid on a world map

forefront generally due to their longstanding policies on humanitarian aid. Kuwait was not the largest in absolute contribution, but when its economic size is taken into account it ranks eighth.

\subsubsection{Regional Analysis}

See Fig. 6.

Asia As we take into consideration the economic size of each country, it is not the states with the largest absolute donations that rank the highest, but those who contribute greatly in comparison with their GDP per capita. This explains why Pakistan, 


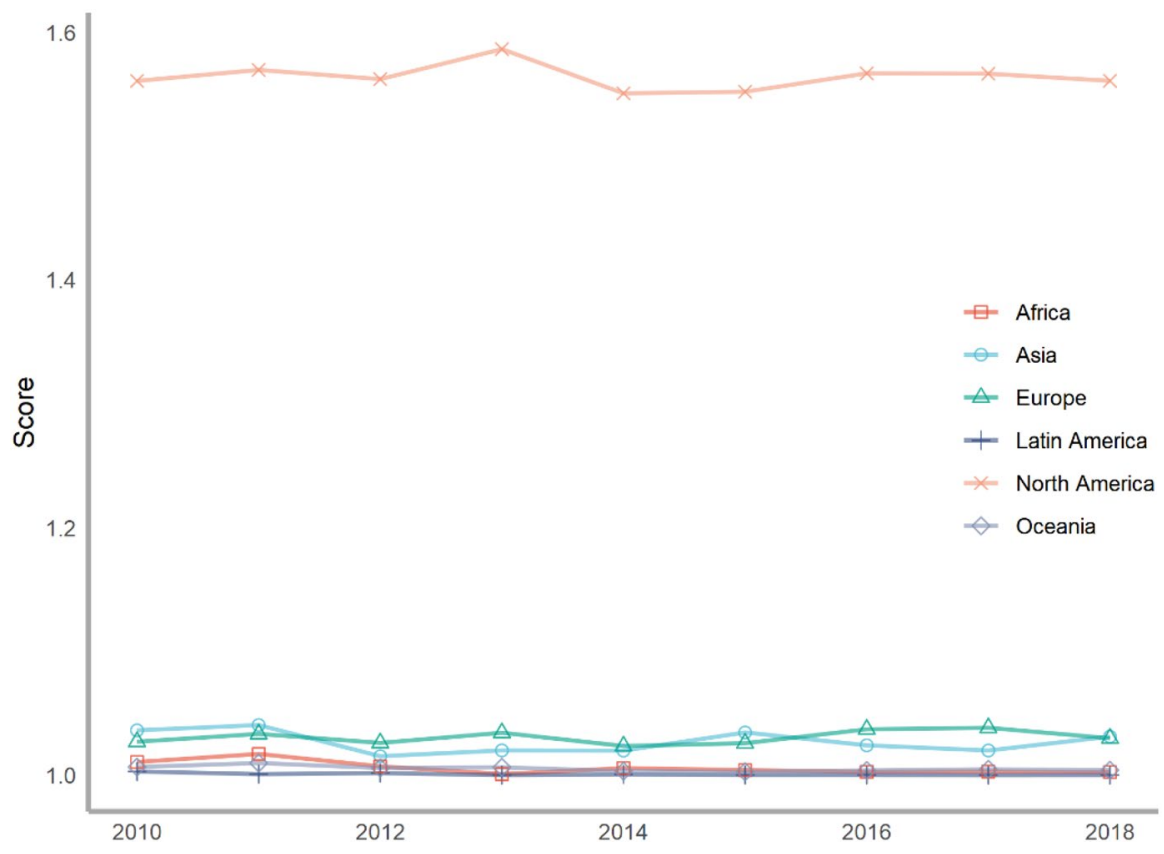

Fig. 6 Score of humanitarian aid issue across continents, 2010-2018

a country in South Asia, ranked tenth in 2018. According to the data, the total outgoing funding of Pakistan is about 13 million dollars. It is not a large number compared with most of the economically significant countries. For example, the Republic of Korea, which ranked 23rd in 2018, had a total outgoing funding of about 108 million dollars. However, the GDP per capita of Pakistan is 1482 dollars according to the World Bank, while that of Korea in 2018 was 33,340 dollars. When we take into the consideration their respective economic sizes and capabilities, Pakistan obtained a higher rank than Korea in 2018 with a lower absolute level of donations.

Under this measurement, Asian countries performed well on the issue of humanitarian aid in 2018. Among the top 30 countries, there were nine countries from Asia: Saudi Arabia, United Arab Emirates, Kuwait, Japan, Pakistan, Afghanistan, Republic of Korea, China and Qatar. Among these countries, there were not only rich oil states in West Asia, but also economically small countries in Central and South Asia. Countries in East Asia with close economic cooperation and high economic growth rank the forefront as well. Taking China as an example, foreign aid from China focuses generally on "large-scale infrastructure projects, energy facilities and commercial cooperation, new emphasis is being given to supporting institutional capacity building and human resource development." ${ }^{28}$ Research shows that Chinese official development assistance (ODA) brings economic growth in recipient countries. For the average recipient country, one Chinese ODA project leads to a

${ }^{28}$ Chin \& Frolic (2007). 
$0.7 \%$ point economic growth increase in 2 years. Through a comparison between the effectiveness of Chinese aid, the World Bank, the United States, and members of the OECD's Development Assistance Committee, the results show that China, the United States and members of the OECD's Development Assistance Committee have positive effects on economic growth, while there is no robust evidence showing that World Bank aid promotes growth. ${ }^{29}$

Europe Humanitarian aid has long been an important part of the EU's agenda. Due to its long-lasting shared commitments on humanitarian assistance and its existing platform for easily transforming willingness into action, European countries perform generally well on this issue. Within the top 30 countries according to our measurement, there are 14 countries from Europe: the United Kingdom, Germany, Sweden, Norway, Denmark, Belgium, Netherlands, Italy, Switzerland, France, Finland, Ireland, Spain and Russia. Most of them are located in the Western Europe.

The EU has a long history of commitment to humanitarian assistance. Humanitarian aid first entered the EU realm through the 1969 Yaounde II Convention, and the EU's spending on humanitarian action doubled between 1986 and 1991. In 1992, the European Community Humanitarian Office (ECHO), an administrative structure exclusively in charge of the management of humanitarian assistance, was established. ${ }^{30}$ In 2007, the Council of the EU, European Parliament and the European Commission signed the European Consensus on Humanitarian Aid, which provides a policy framework for the EU to provide humanitarian aid in the cases of emergencies and humanitarian crises, including natural and man-made disasters. In addition, it outlines a common vision, guidelines and principles and acts as a practical guideline. The EU reaffirms in the statement the fundamental principles of humanity, neutrality, impartiality and independence, which are fundamental to humanitarian action. Based on these fundamental principles, the EU has engaged in a series of international practical initiatives and adopted a number of relevant policies and legal acts.

North America From 2010 to 2018, the United States has maintained first place in humanitarian aid, and Canada has been one of the top 10 countries on this issue. The United States is the largest single provider of humanitarian assistance worldwide. As mentioned above, total outgoing funding from the United States in 2018 was more than 8 billion dollars, which included funding from the State Department's Bureau of Population, Refugees, and Migration and the U.S. Agency for International Development's Bureau for Democracy, Conflict, and Humanitarian Assistance. ${ }^{31}$ South Sudan was the largest recipient country of the United States, followed by the Syrian Arab Republic, Ethiopia, Iraq, Yemen, Somalia, the Democratic Republic of Congo, Sudan, Nigeria, and Bangladesh. In regard to recipient organizations, the WFP received the most, followed by the United Nations High

\footnotetext{
${ }^{29}$ Dreher et al. (2017).

30 Helen Versluys (2008).

31 https://www.state.gov/policy-issues/refugee-and-humanitarian-assistance/\#: :text=Total\%20U.S.\% 20humanitarian $\% 20$ assistance $\% 20$ worldwide, $\% 2$ C $\% 20$ Conflict $\% 2$ C $\% 20$ and $\% 20$ Humanitarian $\% 20$ Ass istance.
} 
Commissioner for Refugees, the United Nations Children's Fund, Catholic Relief Services and the International Organization for Migration.

For Canada, the total outgoing funding in 2018 was more than 500 million. Most of it went to the food security sector and the health sector. The Syrian Arab Republic was the largest recipient country of Canadian assistance, followed by the Democratic Republic of Congo, Iraq, Lebanon, South Sudan, Bangladesh, Yemen and Ethiopia. In regard to recipient organizations, the WFP was the largest recipient, followed by the United Nations Children's Fund, the International Committee of the Red Cross, the United Nations High Commissioner for Refugees and the United Nations Population Fund.

Latin America Latin America is a region exposed to multiple natural crises. There have been various humanitarian assistance programs and initiatives between Latin America and North America and the EU. From 2016, the EU allocated $€ 12.7$ million through Disaster Risk Reduction (DRR) projects in Bolivia, Colombia, Ecuador, Paraguay, Peru and Venezuela, which includes $€ 2.25$ million in humanitarian assistance towards the 2017 floods in northern Peru and $€ 3$ million in response to the 2014 severe floods in Bolivia. ${ }^{32}$ The European Union Civil Protection Mechanism was another project through which Latin American countries received immediate assistance in the face of emergencies and disasters. For example, through this project the EU allocated $€ 5$ million to assist Ecuador after the deadly earthquake in 2016. Additionally, this project has assisted Chile in 2017 in response to forest fires, Bolivia in 2016 in response to drought, and Peru in 2017 in response to floods. ${ }^{33}$

Although Latin America is commonly understood as a recipient region of humanitarian assistance, Brazil and Mexico performed well under our measurement, with rankings of 31 and 38 in 2018. Total outgoing funding from Mexico in 2018 was about 1 million dollars, through the United Nations Children's Fund. The total outgoing funding of Brazil was more than 3 million dollars, through the United Nations Relief and Works Agency for Palestine Refugees in the Near East, the International Organization for Migration, the Food \& Agriculture Organization of the United Nations and the International Organization for Migration.

Africa Due to the combined effect of food shortages, natural disasters, poverty, conflict and climate change, Africa is in need of humanitarian assistance. "Burkina Faso, Mali and Niger are at the epicenter of one of the world's fastest-growing humanitarian crises. Vulnerable people living in conflict-hit areas are facing, for the fourth consecutive year, a food crisis due to the overlapping challenges in the region. More than a quarter of the population in the Central African Republic is either internally displaced or living as a refugee in neighboring countries." 34 Humanitarian assistance acts as the major support for the survival of a large number of people in Africa. According to the data, among the top twenty affected countries, ten of them are in Africa. They are South Sudan, Somalia, the Democratic Republic of Congo, Nigeria, Ethiopia, Sudan, Central African Republic, Uganda, Niger and Chad.

\footnotetext{
32 https://ec.europa.eu/echo/where/latin-america-caribbean/south-america_en.

33 https://ec.europa.eu/echo/where/latin-america-caribbean/south-america_en.

34 https://ec.europa.eu/echo/where/africa_en.
} 
Besides humanitarian assistance in food and security, the continent also receives foreign aid for infrastructure and energy facilities. China is one of the major donors to African countries. Foreign aid to Africa counts for nearly half of China's foreign aid. Most of it goes to infrastructure projects, technical assistance and public works. China started to provide foreign aid to Africa in 1955, and this grew steadily between 1973 and 1979. Between 2003 and 2013 54\% of China's overall humanitarian assistance went to sub-Saharan Africa countries, and the three largest recipient countries were Ethiopia, Kenya and Somalia. ${ }^{35}$ In 2017, China provided Nigeria, South Sudan, Kenya and Ethiopia with about 7 million, 14 million, 21 million and 15 million in USD in financial assistance, respectively.

Oceania Generally speaking, Oceania performed well in humanitarian assistance in 2018. Australia ranked 30th under our measurement, and New Zealand ranked 32nd. The total outgoing funding of Australia was more than 314 million in USD in 2018. Most of it went to coordination and support services and the food security sector. The largest recipient countries were Bangladesh, Afghanistan, Jordan, the Syrian Arab Republic, Iraq, Lebanon, Myanmar, Tonga and Somalia. Regarding the recipient organizations, the largest recipients were the United Nations High Commissioner for Refugees, the World Food Programme, the Office for the Coordination of Humanitarian Affairs, the International Committee of the Red Cross, and the United Nations Children's Fund. For New Zealand, the total outgoing funding in 2018 was more than 22 million in USD. Most of it went to coordination and support services and the early recovery sector. The largest recipient countries were Yemen, Tonga, Papua New Guinea, Bangladesh, Indonesia, the Syrian Arab Republic, South Sudan, Somalia and Ethiopia. And the largest recipient organizations were the International Committee of the Red Cross, the Central Emergency Response Fund, the World Food Programme, the United Nations High Commissioner for Refugees, and Caritas New Zealand.

\subsubsection{Conclusion}

Humanitarian assistance has long been an important part of global justice. In this section, we measure the contribution of each nation state to providing humanitarian assistance across 11 indicators in all, measuring the donation to different sectors including food, health, water, emergency response, early recovery, coordination, education, protection, agriculture, housing and others (i.e. donations without a designated use). According to our measurement, the top ten countries in 2018 were the United States, Saudi Arabia, the United Arab Emirates, the United Kingdom, Germany, Canada, Kuwait, Japan and Sweden. The United States has maintained first place from 2010 to 2018. Arab countries with strong petroleum reserves and developed countries in Europe also ranked at the forefront.

${ }_{35} \operatorname{Bogg}(2015)$. 


\subsection{Issue 4: Anti-terrorism and Conflicts}

\subsubsection{Introduction}

Terrorist activities have been relatively uncommon throughout history, but since the twentieth century terrorism has become a major global problem. Although 20 years have passed since the September 11 incident in 2001, its impact on the world has not yet completely dissipated. With in-depth study of terrorism in countries around the world, our understanding of terrorism is constantly deepening. However, the definition of terrorism has become increasingly vague. Some organizations are recognized as terrorist organizations by some countries, but they cannot be called terrorist organizations according to the standards of other countries. Although differences in this regard cannot be resolved, there is a global consensus on the need to fight against terrorism. This is because not only developed countries face the threat of terrorism, developing countries are also not free from terrorism. Domestic and regional conflicts also occur frequently around the world. Especially in recent years, there have been more and more conflicts caused by the gap between the rich and the poor, economic fluctuations and ethnic conflicts.

Terrorist activities and various armed conflicts are major challenges and threats facing the world today. Countries are under great pressure in countering terrorism and reducing armed conflicts. Currently, regional and local armed conflicts are quite common, resulting in great trauma to the affected countries and people. Meanwhile, terrorist organizations and terrorist activities are very active, threatening regional and world peace and development. Some extremist organizations resort to undifferentiated violence against civilians for various political, cultural and religious reasons. These acts are harmful to global justice. For now, the international community generally believes that national efforts and global cooperation are the main measures to combat terrorism and reduce the threat of conflicts. In this section, we measure the efforts and effectiveness of countries in responding to terrorism and armed conflict in order to measure their contribution to global justice on this issue.

\subsubsection{Dimensions and Indicators}

Our study attempts to measure the contribution of various countries to global justice in response to terrorism and armed conflict. Terrorist attacks and armed conflicts are negatively related to global justice and, therefore, are negative performance measures. If a country is involved in more terrorist attacks and armed conflicts, it means that it contributes less to global justice; by contrast, peace agreements are positively related to global justice and therefore are a positive measurement of contribution. We measure the contribution of various countries to global justice in responding to terrorism and armed conflict across three dimensions: armed conflict, conflict agreements and terrorism (Table 7).

Each dimension has two or three indicators. The armed conflict dimension includes three indicators: number of conflicts, number of wars, and number of 


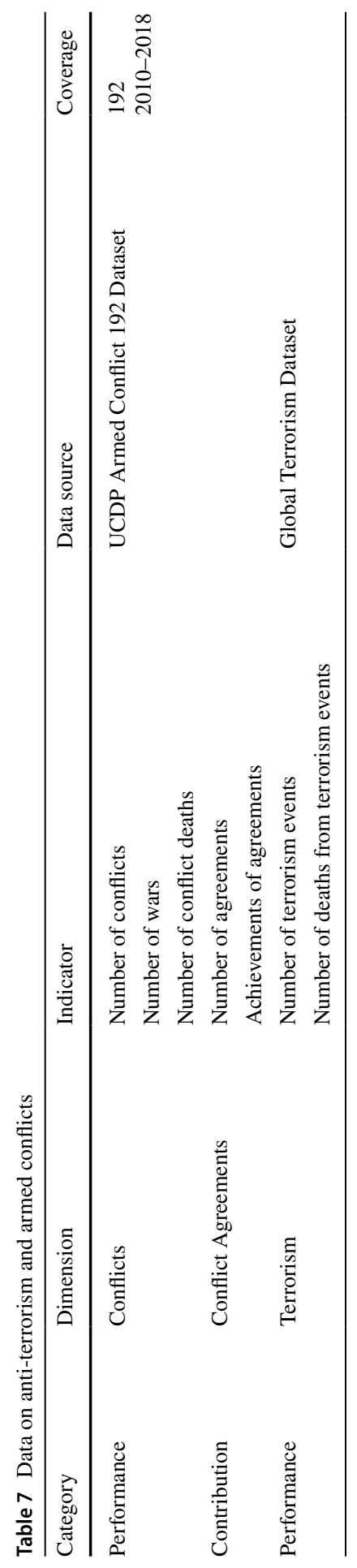


Table 8 Variable code

\begin{tabular}{lll}
\hline Indicator & Value & Meaning \\
\hline mil_prov & $0-1$ & Whether a military agreement is reached \\
pol_prov & $0-1$ & Whether a political agreement is reached \\
terr_prov & $0-1$ & Whether an agreement on the territory is reached \\
justice_prov & $0-1$ & Whether a judicial agreement is reached \\
outlin & $0-1$ & Whether a negotiation agenda is set \\
pko & $0-1$ & Whether the agreement specify peace-keeping measures \\
pa_type & $1,2,3$ & Agreement quality: $1=$ all, $2=$ partial, 3= preliminary \\
\hline
\end{tabular}

conflict deaths. The conflict agreements dimension includes two indicators: number of agreements and achievement of agreements. The terrorism dimension two indicators: number of terrorist events and number of deaths from terrorist events. These data come from the Uppsala Conflict Data Program (UCDP) and the Global Terrorism Database (GTB). Our calculation method is cumulative measurement. For example, if a conflict breaks out between two countries, and there are deaths in the conflict, then the number of conflicts in those two countries in that year would be increased by one, and the number of deaths due to involvement in conflicts would also increase. In addition, in the dimensions of armed conflict and terrorism, we have adopted population-weighted treatment (namely, divided by the country's population), which is conducive to making our research more scientific.

In terms of the conflict agreement, we use the following algorithm to calculate its results. As is well-known, reaching a peace agreement to resolve an armed conflict is very difficult, because a peace agreement often requires long and arduous negotiations and talks. In order to recognize these long-term efforts and contributions, we use retrospective points to assign values to the indicator scores of each peace agreement. For example, assuming that a peace agreement is signed in year $i$, then the score for the same year is $s$. According to the above-mentioned agreement calculation method, in the previous i-1, i-2, i-3 and i-4 years, we will give $0.5 \mathrm{~s}, 0.3 \mathrm{~s}, 0.2 \mathrm{~s}$ and $0.1 \mathrm{~s}$ to the scores for that country, respectively (Table 8).

The function to measure "achievements of agreements" is as follows:

Achievements of agreements $=$ mil_prov + pol_prov + terr_prov + justice_ prov + outlin + pko $+(3-$ pa_type $) / 2$.

\subsubsection{Results}

In this section, we present the ranking results of the countries' contributions to global justice from the conflicts and anti-terrorism perspectives (Table 9). Table 9 shows 9 years of results from 2010 to 2018 in 192 countries.

The above table shows that from 2010 to 2018, South Sudan, China, Japan, Vietnam, Brazil and other countries have consistently performed well in anti-terrorism and conflicts, ranking among the top 10 globally most of the time. Hot spots such as Tuvalu, Palau, Somalia and Afghanistan have long been at the bottom. The 
Table 9 Country ranking in the anti-terrorism and conflict aspect of promoting global justice

\begin{tabular}{|c|c|c|c|c|c|c|c|c|c|}
\hline Country & 2010 & 2011 & 2012 & 2013 & 2014 & 2015 & 2016 & 2017 & 2018 \\
\hline Ethiopia & 24 & 20 & 28 & 20 & 4 & 4 & 1 & 1 & 1 \\
\hline Eritrea & 3 & 132 & 80 & 79 & 5 & 5 & 2 & 2 & 2 \\
\hline South Sudan & 2 & 1 & 1 & 1 & 1 & 1 & 3 & 3 & 3 \\
\hline China & 8 & 7 & 7 & 7 & 13 & 7 & 4 & 4 & 4 \\
\hline Japan & 10 & 9 & 9 & 8 & 8 & 13 & 7 & 5 & 5 \\
\hline Viet Nam & 12 & 10 & 10 & 9 & 6 & 6 & 6 & 7 & 6 \\
\hline Republic of Korea & 32 & 33 & 30 & 23 & 29 & 10 & 9 & 8 & 7 \\
\hline Brazil & 9 & 8 & 8 & 10 & 7 & 8 & 5 & 6 & 8 \\
\hline Uzbekistan & 20 & 17 & 13 & 13 & 12 & 16 & 10 & 9 & 9 \\
\hline Angola & 44 & 24 & 16 & 14 & 14 & 14 & 19 & 37 & 10 \\
\hline Poland & 45 & 40 & 38 & 28 & 38 & 9 & 16 & 10 & 11 \\
\hline Democratic People's Republic of Korea & 26 & 23 & 17 & 15 & 15 & 15 & 13 & 12 & 12 \\
\hline United Republic of Tanzania & 17 & 13 & 11 & 34 & 37 & 45 & 15 & 19 & 13 \\
\hline Spain & 43 & 36 & 36 & 36 & 42 & 11 & 14 & 28 & 14 \\
\hline Kazakhstan & 31 & 79 & 61 & 47 & 17 & 19 & 51 & 15 & 15 \\
\hline Argentina & 35 & 15 & 18 & 16 & 11 & 12 & 12 & 13 & 16 \\
\hline Madagascar & 29 & 32 & 27 & 27 & 20 & 24 & 26 & 11 & 17 \\
\hline Cote d'Ivoire & 30 & 28 & 20 & 22 & 16 & 25 & 17 & 18 & 18 \\
\hline Romania & 73 & 66 & 62 & 56 & 63 & 30 & 24 & 22 & 19 \\
\hline Morocco & 18 & 46 & 12 & 12 & 10 & 38 & 22 & 17 & 20 \\
\hline Cuba & 42 & 44 & 40 & 29 & 31 & 33 & 30 & 24 & 21 \\
\hline Indonesia & 11 & 26 & 31 & 21 & 18 & 17 & 11 & 14 & 22 \\
\hline Bangladesh & 39 & 27 & 23 & 88 & 78 & 120 & 70 & 35 & 23 \\
\hline Dominican Republic & 51 & 52 & 44 & 44 & 45 & 39 & 33 & 45 & 24 \\
\hline Malawi & 37 & 34 & 29 & 40 & 19 & 21 & 18 & 21 & 25 \\
\hline Peru & 19 & 18 & 66 & 64 & 55 & 57 & 35 & 44 & 26 \\
\hline Honduras & 58 & 71 & 50 & 72 & 49 & 42 & 48 & 51 & 27 \\
\hline Belarus & 76 & 86 & 72 & 33 & 36 & 41 & 34 & 32 & 28 \\
\hline Germany & 13 & 30 & 14 & 11 & 24 & 83 & 66 & 38 & 29 \\
\hline Russian Federation & 126 & 112 & 105 & 102 & 56 & 52 & 71 & 53 & 30 \\
\hline Mexico & 16 & 11 & 34 & 25 & 9 & 26 & 8 & 23 & 31 \\
\hline Australia & 67 & 62 & 58 & 52 & 90 & 93 & 75 & 70 & 32 \\
\hline Italy & 55 & 41 & 49 & 32 & 40 & 18 & 29 & 20 & 33 \\
\hline Zambia & 40 & 38 & 33 & 24 & 23 & 23 & 21 & 31 & 34 \\
\hline Papua New Guinea & 64 & 60 & 57 & 43 & 44 & 43 & 37 & 95 & 35 \\
\hline United States of America & 22 & 14 & 15 & 17 & 25 & 34 & 40 & 40 & 36 \\
\hline Malaysia & 53 & 55 & 59 & 75 & 72 & 37 & 73 & 29 & 37 \\
\hline Ghana & 25 & 22 & 37 & 26 & 32 & 32 & 32 & 25 & 38 \\
\hline Cambodia & 38 & 42 & 32 & 48 & 30 & 40 & 27 & 30 & 39 \\
\hline France & 41 & 48 & 99 & 51 & 59 & 100 & 82 & 85 & 40 \\
\hline Algeria & 143 & 80 & 107 & 105 & 64 & 67 & 39 & 54 & 41 \\
\hline Zimbabwe & 57 & 53 & 35 & 53 & 35 & 28 & 25 & 42 & 42 \\
\hline
\end{tabular}


Table 9 (continued)

\begin{tabular}{|c|c|c|c|c|c|c|c|c|c|}
\hline Country & 2010 & 2011 & 2012 & 2013 & 2014 & 2015 & 2016 & 2017 & 2018 \\
\hline Azerbaijan & 100 & 95 & 94 & 92 & 101 & 44 & 62 & 76 & 43 \\
\hline Guatemala & 36 & 35 & 45 & 68 & 22 & 22 & 20 & 16 & 44 \\
\hline Canada & 59 & 45 & 53 & 45 & 67 & 54 & 47 & 49 & 45 \\
\hline Lao People's Democratic Republic & 69 & 65 & 70 & 50 & 48 & 77 & 88 & 66 & 46 \\
\hline Benin & 52 & 54 & 46 & 49 & 43 & 49 & 36 & 43 & 47 \\
\hline Czechia & 93 & 93 & 85 & 93 & 100 & 80 & 55 & 77 & 48 \\
\hline Kyrgyzstan & 78 & 69 & 65 & 58 & 52 & 55 & 46 & 50 & 49 \\
\hline Portugal & 92 & 98 & 84 & 82 & 86 & 50 & 38 & 47 & 50 \\
\hline Hungary & 96 & 91 & 88 & 85 & 91 & 46 & 49 & 52 & 51 \\
\hline Turkmenistan & 80 & 72 & 67 & 61 & 76 & 58 & 52 & 55 & 52 \\
\hline Singapore & 119 & 117 & 115 & 111 & 54 & 59 & 53 & 56 & 53 \\
\hline Uganda & 99 & 21 & 55 & 19 & 85 & 56 & 87 & 59 & 54 \\
\hline Slovakia & 115 & 113 & 114 & 110 & 108 & 61 & 54 & 58 & 55 \\
\hline Congo & 85 & 76 & 73 & 84 & 61 & 64 & 144 & 62 & 56 \\
\hline Bulgaria & 104 & 109 & 117 & 109 & 102 & 72 & 57 & 41 & 57 \\
\hline Iran (Islamic Republic of) & 86 & 51 & 22 & 39 & 26 & 73 & 59 & 57 & 58 \\
\hline Guinea & 48 & 47 & 41 & 63 & 39 & 66 & 44 & 39 & 59 \\
\hline Costa Rica & 81 & 74 & 71 & 66 & 60 & 65 & 61 & 63 & 60 \\
\hline Sri Lanka & 54 & 29 & 51 & 80 & 79 & 74 & 23 & 112 & 61 \\
\hline Oman & 97 & 89 & 79 & 74 & 65 & 70 & 64 & 68 & 62 \\
\hline Togo & 65 & 63 & 60 & 65 & 53 & 68 & 50 & 67 & 63 \\
\hline Switzerland & 62 & 82 & 54 & 67 & 41 & 63 & 67 & 60 & 64 \\
\hline Austria & 102 & 101 & 95 & 100 & 97 & 60 & 72 & 75 & 65 \\
\hline Panama & 89 & 83 & 77 & 73 & 66 & 76 & 81 & 73 & 66 \\
\hline Kuwait & 98 & 102 & 82 & 78 & 68 & 132 & 114 & 74 & 67 \\
\hline Croatia & 125 & 124 & 121 & 123 & 117 & 71 & 68 & 72 & 68 \\
\hline Serbia & 79 & 61 & 83 & 46 & 46 & 48 & 42 & 61 & 69 \\
\hline Haiti & 50 & 50 & 42 & 31 & 34 & 36 & 56 & 27 & 70 \\
\hline Netherlands & 83 & 78 & 69 & 62 & 93 & 85 & 84 & 34 & 71 \\
\hline Bolivia (Plurinational State of) & 49 & 49 & 56 & 30 & 33 & 35 & 31 & 26 & 72 \\
\hline El Salvador & 71 & 108 & 109 & 107 & 104 & 75 & 60 & 78 & 73 \\
\hline United Arab Emirates & 105 & 97 & 91 & 97 & 116 & 102 & 101 & 69 & 74 \\
\hline India & 88 & 75 & 68 & 69 & 69 & 78 & 79 & 84 & 75 \\
\hline Senegal & 63 & 94 & 108 & 70 & 58 & 51 & 28 & 33 & 76 \\
\hline Republic of Moldova & 90 & 85 & 93 & 76 & 70 & 79 & 86 & 81 & 77 \\
\hline Uruguay & 94 & 88 & 81 & 81 & 73 & 81 & 91 & 83 & 78 \\
\hline Venezuela (Bolivarian Republic of) & 21 & 19 & 19 & 18 & 28 & 27 & 41 & 79 & 79 \\
\hline South Africa & 14 & 12 & 24 & 41 & 51 & 20 & 65 & 71 & 80 \\
\hline Egypt & 15 & 57 & 76 & 139 & 136 & 157 & 148 & 148 & 81 \\
\hline Norway & 123 & 157 & 116 & 114 & 114 & 84 & 69 & 90 & 82 \\
\hline Belgium & 91 & 87 & 89 & 86 & 110 & 96 & 120 & 102 & 83 \\
\hline Jordan & 117 & 68 & 75 & 71 & 118 & 116 & 131 & 123 & 84 \\
\hline
\end{tabular}


Table 9 (continued)

\begin{tabular}{|c|c|c|c|c|c|c|c|c|c|}
\hline Country & 2010 & 2011 & 2012 & 2013 & 2014 & 2015 & 2016 & 2017 & 2018 \\
\hline Mongolia & 140 & 141 & 134 & 129 & 129 & 87 & 80 & 88 & 85 \\
\hline Ecuador & 34 & 43 & 39 & 38 & 21 & 31 & 58 & 36 & 86 \\
\hline Ukraine & 6 & 4 & 4 & 3 & 2 & 3 & 105 & 105 & 87 \\
\hline Sweden & 106 & 99 & 98 & 95 & 103 & 130 & 111 & 120 & 88 \\
\hline New Zealand & 124 & 123 & 119 & 115 & 119 & 69 & 76 & 65 & 89 \\
\hline Jamaica & 101 & 96 & 90 & 90 & 92 & 89 & 83 & 104 & 90 \\
\hline Myanmar & 60 & 16 & 64 & 54 & 50 & 92 & 108 & 135 & 91 \\
\hline Liberia & 87 & 81 & 87 & 87 & 82 & 90 & 74 & 93 & 92 \\
\hline Rwanda & 108 & 73 & 103 & 96 & 57 & 47 & 43 & 48 & 93 \\
\hline Denmark & 121 & 111 & 112 & 112 & 128 & 121 & 115 & 80 & 94 \\
\hline Sierra Leone & 66 & 64 & 86 & 77 & 74 & 86 & 85 & 101 & 95 \\
\hline Albania & 138 & 139 & 131 & 132 & 135 & 110 & 103 & 97 & 96 \\
\hline Qatar & 112 & 105 & 101 & 98 & 84 & 129 & 119 & 113 & 97 \\
\hline Finland & 116 & 114 & 113 & 113 & 111 & 112 & 92 & 96 & 98 \\
\hline Paraguay & 95 & 100 & 97 & 120 & 121 & 131 & 125 & 109 & 99 \\
\hline Georgia & 152 & 143 & 135 & 127 & 127 & 91 & 110 & 89 & 100 \\
\hline Namibia & 107 & 103 & 102 & 101 & 89 & 97 & 90 & 92 & 101 \\
\hline Botswana & 111 & 106 & 104 & 103 & 94 & 98 & 95 & 94 & 102 \\
\hline Mauritania & 109 & 116 & 78 & 94 & 77 & 95 & 78 & 91 & 103 \\
\hline Gabon & 120 & 115 & 111 & 108 & 98 & 101 & 99 & 133 & 104 \\
\hline Lesotho & 110 & 107 & 106 & 104 & 95 & 105 & 97 & 98 & 105 \\
\hline Republic of North Macedonia & 150 & 148 & 150 & 140 & 146 & 123 & 96 & 107 & 106 \\
\hline Slovenia & 151 & 150 & 144 & 141 & 141 & 99 & 98 & 99 & 107 \\
\hline Sudan & 1 & 3 & 2 & 4 & 150 & 142 & 146 & 134 & 108 \\
\hline Guinea-Bissau & 122 & 119 & 125 & 119 & 107 & 114 & 112 & 121 & 109 \\
\hline Lebanon & 118 & 129 & 140 & 174 & 175 & 161 & 157 & 144 & 110 \\
\hline Turkey & 68 & 92 & 138 & 91 & 99 & 147 & 164 & 130 & 111 \\
\hline Kenya & 74 & 104 & 127 & 125 & 133 & 119 & 109 & 125 & 112 \\
\hline $\begin{array}{l}\text { United Kingdom of Great Britain and } \\
\text { Northern Ireland }\end{array}$ & 103 & 90 & 92 & 117 & 105 & 104 & 107 & 116 & 113 \\
\hline Ireland & 134 & 136 & 157 & 152 & 153 & 145 & 132 & 140 & 114 \\
\hline Tajikistan & 84 & 59 & 96 & 60 & 62 & 94 & 63 & 64 & 115 \\
\hline Nicaragua & 75 & 67 & 63 & 55 & 80 & 53 & 45 & 46 & 116 \\
\hline Armenia & 139 & 140 & 137 & 131 & 132 & 113 & 124 & 106 & 117 \\
\hline Bosnia and Herzegovina & 133 & 134 & 124 & 124 & 131 & 125 & 77 & 100 & 118 \\
\hline Lithuania & 135 & 137 & 130 & 126 & 130 & 88 & 93 & 103 & 119 \\
\hline Gambia & 113 & 110 & 110 & 106 & 96 & 106 & 104 & 111 & 120 \\
\hline Niger & 77 & 58 & 47 & 89 & 75 & 162 & 135 & 126 & 121 \\
\hline Equatorial Guinea & 137 & 135 & 128 & 122 & 113 & 111 & 118 & 115 & 122 \\
\hline Timor-Leste & 130 & 130 & 123 & 118 & 112 & 109 & 117 & 117 & 123 \\
\hline Mauritius & 127 & 126 & 122 & 116 & 109 & 107 & 116 & 114 & 124 \\
\hline Cyprus & 129 & 128 & 136 & 157 & 143 & 138 & 133 & 119 & 125 \\
\hline
\end{tabular}


Table 9 (continued)

\begin{tabular}{|c|c|c|c|c|c|c|c|c|c|}
\hline Country & 2010 & 2011 & 2012 & 2013 & 2014 & 2015 & 2016 & 2017 & 2018 \\
\hline Latvia & 149 & 149 & 145 & 142 & 142 & 108 & 100 & 127 & 126 \\
\hline Tunisia & 46 & 77 & 74 & 130 & 123 & 135 & 127 & 87 & 127 \\
\hline Eswatini & 131 & 131 & 126 & 121 & 115 & 115 & 121 & 122 & 128 \\
\hline Burundi & 148 & 133 & 100 & 83 & 88 & 168 & 165 & 131 & 129 \\
\hline Chile & 72 & 70 & 43 & 57 & 83 & 29 & 89 & 82 & 130 \\
\hline Trinidad and Tobago & 136 & 125 & 120 & 138 & 106 & 117 & 113 & 110 & 131 \\
\hline Greece & 154 & 118 & 129 & 149 & 124 & 118 & 126 & 141 & 132 \\
\hline Thailand & 153 & 145 & 146 & 154 & 145 & 133 & 143 & 128 & 133 \\
\hline Saudi Arabia & 23 & 37 & 52 & 35 & 81 & 141 & 145 & 118 & 134 \\
\hline Fiji & 141 & 142 & 133 & 128 & 122 & 122 & 128 & 132 & 135 \\
\hline Chad & 56 & 39 & 48 & 59 & 71 & 156 & 94 & 108 & 136 \\
\hline Pakistan & 159 & 163 & 164 & 165 & 160 & 155 & 149 & 149 & 137 \\
\hline Estonia & 158 & 161 & 154 & 155 & 154 & 136 & 123 & 137 & 138 \\
\hline Mozambique & 27 & 25 & 25 & 99 & 87 & 62 & 130 & 86 & 139 \\
\hline Guyana & 144 & 146 & 141 & 133 & 125 & 128 & 140 & 138 & 140 \\
\hline Nepal & 114 & 121 & 118 & 136 & 47 & 103 & 106 & 160 & 141 \\
\hline Solomon Islands & 156 & 152 & 147 & 144 & 134 & 134 & 137 & 143 & 142 \\
\hline Luxembourg & 172 & 172 & 169 & 166 & 164 & 137 & 138 & 146 & 143 \\
\hline Suriname & 155 & 153 & 148 & 146 & 137 & 139 & 141 & 147 & 144 \\
\hline Colombia & 142 & 127 & 139 & 137 & 140 & 126 & 122 & 129 & 145 \\
\hline Cabo Verde & 157 & 155 & 149 & 148 & 139 & 140 & 142 & 150 & 146 \\
\hline Bahrain & 145 & 138 & 176 & 181 & 177 & 174 & 166 & 170 & 147 \\
\hline Democratic Republic of the Congo & 7 & 6 & 6 & 6 & 120 & 124 & 134 & 139 & 148 \\
\hline Burkina Faso & 33 & 31 & 26 & 37 & 27 & 82 & 102 & 124 & 149 \\
\hline Comoros & 146 & 147 & 142 & 134 & 126 & 127 & 129 & 136 & 150 \\
\hline Malta & 160 & 156 & 152 & 150 & 152 & 154 & 151 & 164 & 151 \\
\hline Djibouti & 4 & 144 & 153 & 143 & 151 & 152 & 150 & 154 & 152 \\
\hline Bhutan & 147 & 154 & 143 & 135 & 138 & 143 & 139 & 152 & 153 \\
\hline Brunei Darussalam & 161 & 158 & 155 & 151 & 144 & 146 & 153 & 153 & 154 \\
\hline Philippines & 132 & 122 & 132 & 153 & 147 & 151 & 155 & 158 & 155 \\
\hline Nigeria & 82 & 120 & 151 & 147 & 162 & 163 & 152 & 151 & 156 \\
\hline Bahamas & 163 & 162 & 156 & 158 & 148 & 148 & 156 & 155 & 157 \\
\hline Belize & 164 & 164 & 158 & 160 & 149 & 149 & 158 & 156 & 158 \\
\hline Israel & 128 & 160 & 159 & 145 & 173 & 150 & 154 & 142 & 159 \\
\hline Iceland & 179 & 178 & 179 & 173 & 176 & 153 & 160 & 159 & 160 \\
\hline Maldives & 162 & 159 & 160 & 161 & 169 & 160 & 159 & 163 & 161 \\
\hline Vanuatu & 167 & 167 & 163 & 159 & 156 & 159 & 163 & 162 & 162 \\
\hline Montenegro & 168 & 168 & 165 & 167 & 163 & 144 & 136 & 145 & 163 \\
\hline Barbados & 166 & 165 & 161 & 156 & 155 & 158 & 162 & 161 & 164 \\
\hline Cameroon & 61 & 56 & 21 & 42 & 157 & 166 & 147 & 157 & 165 \\
\hline Sao Tome and Principe & 170 & 170 & 167 & 162 & 158 & 164 & 167 & 166 & 166 \\
\hline Samoa & 169 & 169 & 166 & 163 & 159 & 165 & 169 & 167 & 167 \\
\hline
\end{tabular}


Table 9 (continued)

\begin{tabular}{|c|c|c|c|c|c|c|c|c|c|}
\hline Country & 2010 & 2011 & 2012 & 2013 & 2014 & 2015 & 2016 & 2017 & 2018 \\
\hline Saint Lucia & 171 & 171 & 168 & 164 & 161 & 167 & 170 & 168 & 168 \\
\hline Mali & 47 & 5 & 5 & 5 & 3 & 2 & 161 & 165 & 169 \\
\hline Yemen & 165 & 166 & 171 & 168 & 178 & 181 & 179 & 169 & 170 \\
\hline Kiribati & 177 & 176 & 174 & 171 & 165 & 170 & 172 & 171 & 171 \\
\hline Central African Republic & 5 & 2 & 3 & 2 & 182 & 169 & 171 & 181 & 172 \\
\hline Micronesia (Federated States of) & 178 & 177 & 175 & 172 & 168 & 173 & 174 & 172 & 173 \\
\hline Grenada & 175 & 175 & 173 & 170 & 166 & 171 & 173 & 173 & 174 \\
\hline Saint Vincent and the Grenadines & 174 & 174 & 172 & 169 & 167 & 172 & 175 & 174 & 175 \\
\hline Tonga & 176 & 189 & 189 & 188 & 187 & 175 & 176 & 175 & 176 \\
\hline Seychelles & 181 & 181 & 178 & 176 & 171 & 177 & 177 & 176 & 177 \\
\hline Antigua and Barbuda & 182 & 180 & 177 & 175 & 170 & 176 & 178 & 177 & 178 \\
\hline Libya & 70 & 84 & 162 & 184 & 188 & 188 & 188 & 180 & 179 \\
\hline Andorra & 183 & 182 & 180 & 177 & 172 & 178 & 180 & 178 & 180 \\
\hline Dominica & 184 & 183 & 181 & 179 & 174 & 179 & 181 & 179 & 181 \\
\hline Syrian Arab Republic & 28 & 151 & 170 & 178 & 181 & 187 & 185 & 183 & 182 \\
\hline Iraq & 187 & 186 & 185 & 190 & 192 & 190 & 190 & 189 & 183 \\
\hline Marshall Islands & 185 & 184 & 183 & 182 & 179 & 180 & 182 & 182 & 184 \\
\hline Saint Kitts and Nevis & 186 & 185 & 184 & 183 & 180 & 182 & 183 & 184 & 185 \\
\hline Somalia & 173 & 173 & 182 & 180 & 186 & 183 & 186 & 186 & 186 \\
\hline Monaco & 188 & 187 & 187 & 186 & 183 & 185 & 184 & 185 & 187 \\
\hline San Marino & 189 & 188 & 188 & 187 & 185 & 186 & 187 & 187 & 188 \\
\hline Afghanistan & 180 & 179 & 186 & 185 & 184 & 184 & 168 & 188 & 189 \\
\hline Palau & 190 & 190 & 190 & 189 & 189 & 189 & 189 & 190 & 190 \\
\hline Nauru & 192 & 192 & 192 & 192 & 190 & 191 & 191 & 191 & 191 \\
\hline Tuvalu & 191 & 191 & 191 & 191 & 191 & 192 & 192 & 192 & 192 \\
\hline
\end{tabular}

top-ranked countries perform well in the dimensions of counter-terrorism and conflicts, mainly because they are rarely involved in large or small conflicts, and their domestic terrorism is well governed and there is almost no record of casualties in terrorist activities. In other countries, the signing of peace agreements in recent years ended or ameliorated long-standing armed conflicts, which has also greatly improved their scores and ranks among the top few, for example as in Ethiopia, Eritrea and South Sudan, which ranked the top three in 2018. In addition to those lowranking countries which still frequently suffer from domestic and international turmoil and have more people who died from terrorist attacks and domestic and foreign conflicts, some countries rank lower simply due to having a smaller population. For example, according to our population-weighted algorithm, the average number of deaths and other indicators score particularly lowly for, Palau, Nauru and Tuvalu, which were at the bottom in 2018.

Compared with other topics, there are more fluctuations in the ranking of countries in the field of counter-terrorism and conflict. Countries with significant changes 
in national rankings are roughly divided into two categories. Sudden changes are often due to the signing of peace agreements. As mentioned previously, these include countries such as Eritrea, Ukraine, and Sudan. The score for the year with the peace agreement often differs from the year without such an agreement by up to 100 places. The main reason why the signing of a peace agreement has such a big impact on the ranking is that the score gap between countries on the two dimensions of anti-terrorism and conflict is not very large. In this case, the difference in the scores of the conflicting agreement dimensions can have a major impact on the final ranking. The logic behind this algorithm is that we hope that more countries can sign agreements to end states of conflict, because regional conflicts and conflicts between countries have a very negative impact on global justice. In addition to some countries with sudden changes in rankings, there are also some countries with large but relatively slow ranking changes, such as Singapore, Russia and Nicaragua. The main reason for the changes in the ranking of these countries is the increase or decrease in the number of casualties due to conflicts and terrorist attacks. This can lead to large changes in the rankings of these countries, which are about 50 points, between 2010 and 2018 .

China's ranking was basically stable from 2010 to 2018, with relatively small changes in casualties caused by terrorist attacks and conflicts, and as a result it has long ranked among the top 10 in the world. The Chinese government attaches great importance to social stability, national security and social harmony and stability. Because of the state's emphasis on and investment in counter-terrorism, terrorist activities rarely occur in China, and casualties caused by terrorism are relatively small. South Sudan is a small country in Africa. It became a new sovereign country after gaining independence from Sudan in 2011. Two years after South Sudan's independence, internal conflict broke out in the country, and its society entered into a state of unrest. As such, South Sudan's performance in the dimension of counterterrorism and conflict should be relatively poor. However, the two sides of the South Sudan civil war signed a peace agreement twice in 2015 and 2018, and they have always hoped to end the civil war through a peace agreement. This has led to serious internal conflicts in South Sudan, but it was able to achieve a very high ranking because of the signing of the peace agreements. The main reasons why countries such as Japan, Vietnam, and Brazil rank very high are that they are rarely involved in regional conflicts, their domestic social situations are very stable, and the number of terrorist activities is very small.

Germany's ranking displayed a downward trend and fluctuated greatly from 2010 to 2018. During this period, Germany was not involved in conflicts with other countries. The main reason why the ranking has shown a downward trend and fluctuated greatly is the increase in terrorist attacks in Germany. For example, in July 2016, Germany experienced a series of violent terrorist attacks over a short period of time, making Germany a "new disaster zone" for terrorism. Some Germans believe that these terrorist activities are related to Germany's open refugee policy. The combination of refugee issues and terrorism has made Germany's domestic security situation very serious. It is worth noting that countries such as Spain, France and Turkey are also facing a similar situation to Germany. Terrorist incidents such as the truck crash in Barcelona, Spain in 2017, the truck crash in Nice on the 2016 French National 
Day, the 2015 terrorist attack in Paris and the 2017 Turkish nightclub shooting have repeatedly reminded us that European countries are facing a very large amount of terrorism.

The ranking of the United States displayed a downward trend from 2010 to 2018. The United States has the most powerful military in the world, and it is also the world's police force. It has launched and intervened in many wars and regional conflicts over this century. From this perspective, the performance of the United States in conflict is 1 not satisfactory. However, over the past 10 years, the United States has gradually withdrawn from many regions, deliberately reducing its military power abroad. Moreover, the United States has been stepping up its crackdown on terrorist activities. For example, the United States has successively killed Al Qaeda leader Osama bin Laden and Islamic State leader Baghdadi, making great contributions to anti-terrorism worldwide. The combination of these factors prompted the United States to hover around 30 in the rankings. Although the United States has achieved good results in foreign counter-terrorism, there is no decline in domestic terrorist activities. ${ }^{36}$ Gun attacks have occurred repeatedly, causing large casualties. For example, the 2017 Las Vegas shooting killed 59 people and injured hundreds. This was the most serious case of shooting in the history of the United States. Although it was not ultimately classified as a terrorist attack, it was almost the same as many terrorist attacks in terms of modus operandi and process. The United States will still face many challenges relating to domestic terrorist attacks in future.

The UK was ranked at around 100 from 2010 to 2018, and is relatively lagging among major countries. In many aspects of foreign policy, Britain pursues a policy of following the United States. For example, in the 2003 Iraq War, the United Kingdom resolutely invaded Iraq with the United States despite opposition from many quarters. Facts have proved that the policy of following the United States to war subsequently brought many problems and troubles to Britain. The increase in terrorist attacks is one of the bitter consequences of Britain's intervention in the Iraq War. The 2005 London bombing in England shocked the world. In 2005, several London Underground stations and buses exploded, causing 56 deaths and more than 700 injuries. Since then, the cloud of terrorism has been hanging over Britain. According to British media reports, from 2010 to 2017, a total of 2,029 terrorists were arrested in the UK. As of the end of June 2018, the British MI5 and counterterrorism departments have conducted a total of 676 investigations into various terrorism cases. The Minister of State for Security, Ben Wallace, said that since 2017, the number of terrorists, terrorist attacks and the number of cases under investigation have increased, and the UK's counter-terrorism situation is not optimistic. ${ }^{37}$

India has been ranked around 70 for a long time from 2010 to 2018. India's lagging position is due to the border conflict with Pakistan on the one hand, and the growing threat of terrorism on the other. Data from the Global Terrorism Database (GTD) shows that from 1970 to 2017, there were nearly 180,000 terrorist attacks around the world, of which 31,959 terrorist attacks occurred in South Asia,

\footnotetext{
36 Taylor (2019).

37 https://world.huanqiu.com/article/9CaKrnKbsL7.
} 


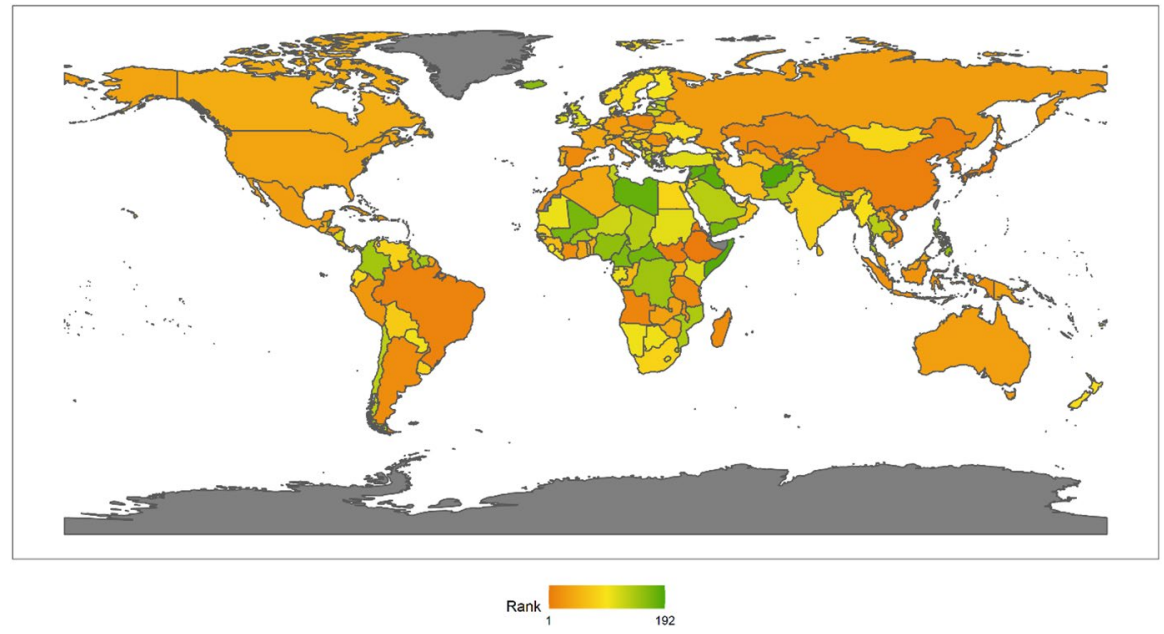

Fig. 72018 Index ranking of conflicts and terrorism on a world map

accounting for about $18 \%$ of the total. More importantly, the proportion of attacks occurring in South Asia has been increasing year by year in recent years. In 2017, for example, South Asia suffered 3430 terrorist attacks, accounting for $31 \%$ of the total. ${ }^{38}$ India is the most important country in South Asia and has suffered the most terrorist attacks. The reason for this is that India's complexity with regard to religion, ethnic group, caste, language, etc. and its proximity to Middle Eastern countries, make it easy for terrorist organizations to target.

From 2010 to 2018, Russia's ranking was on a sharp upward trend. Russia suffered many terrorist attacks at the beginning of this century. Chechen terrorists (exemplified by the "Black Widow") planned and carried out many terrorist attacks, including the hostage-taking incident in the Moscow Palace of Culture in 2002. Over the past 10 years, although the terrorist attacks carried out by Chechen terrorists have not completely stopped, the number and scale have decreased a lot. Although Russia's performance in counter-terrorism has improved, its performance in the field of conflict has been relatively poor. Russia initiated and intervened in wars with Georgia, Ukraine, and Syria in 2008, 2014, and 2015. The occurrence of these wars led to Russia ranking outside the world's 100 prior to 2013. In recent years, with the reduction of conflicts in wars, Russia's ranking in the field of counter-terrorism and conflict has risen sharply.

\subsubsection{Regional Analysis}

In 2018, as mentioned earlier, three African countries ranked in the top three due to the conclusion of agreements (Fig. 7). Among the top ten countries, there are

38 http://www.xinhuanet.com/globe/2019-06/06/c_138094065.htm. 


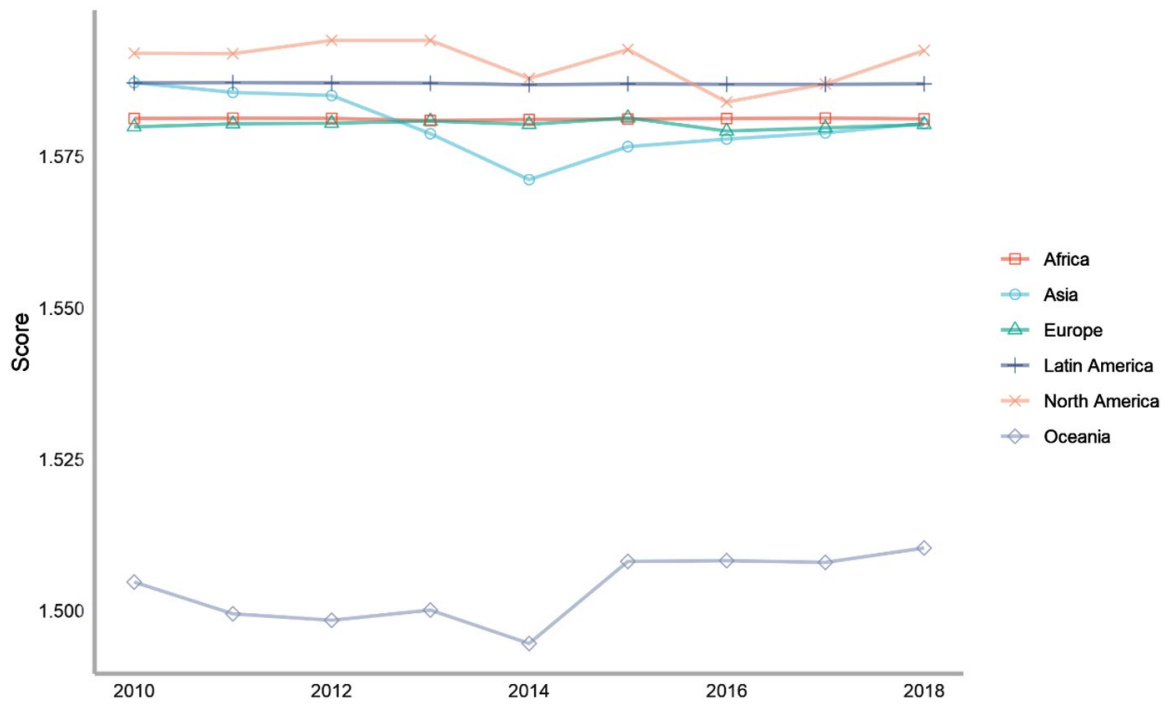

Fig. 8 The score of Anti-terrorism and conflicts issue across continents, 2010-2018

countries that have traditionally performed well, including China, Japan, Vietnam, Brazil, etc., and there are also countries that have steadily increased in recent years, such as South Korea and Uzbekistan. Among the bottom-ranked countries, Afghanistan, Somalia and Iraq are the most populous countries. Syria, Egypt, Papua New Guinea, Sri Lanka, France and Myanmar rose more than 40 places in the rankings, while Nicaragua, Mozambique, Tajikistan, Ecuador, Chile, Bolivia, Rwanda, Senegal and Haiti fell more than 40 places.

Next, we also classify countries according to their continents. These continents include Asia, Europe, North America, Latin America, Africa and Oceania. The ranking of each continent is obtained by calculating the average of the rankings of these countries. We drew a line chart to visually present and compare the differences in the contributions of various continents to counter-terrorism and conflict.

From the above figure, we can find that taking 2018 as an example, in terms of counter-terrorism and conflict, if we compare the average performance of countries on each continent, African countries have contributed the most, followed by North American countries, European countries, Latin American countries and Asia. The countries in Oceania have contributed the least (Fig. 8). The main reason why African countries rank high overall is that the frequency of domestic terrorist activities is relatively low and the number of peace agreements they have signed is relatively low. North American countries only include the United States and Canada, and their performance is slightly lower than that of African countries. The main reason why Oceanian countries rank at the bottom, is that some island countries are lagging behind, and there is no country in the region that has performed particularly prominently in the field of counter-terrorism and conflict.

Asia Most of the countries with stable top rankings are in Asia, and half of the top 10 countries globally are in Asia. This clearly shows that Asian countries have 
performed very well in counter-terrorism and conflict. The top 5 Asian countries are China, Japan, Vietnam, South Korea and Uzbekistan. With the exception of Uzbekistan, which is a Central Asian country, the other four are all East Asian countries. China, Japan, and South Korea are also major economies. China, Japan and South Korea are relatively close in culture, and they all pay attention to domestic societal harmony and stability. These countries have made great achievements in preventing terrorist attacks. Therefore, large-scale terrorist attacks have rarely occurred in the past few years. Yemen, Syria, Iraq, and Afghanistan rank at the bottom in Asia, which is consistent with their domestic political chaos and rampant terrorist activities. In the future, Asian countries may continue to show this kind of polarization. Some Asian countries, represented by East Asian countries, continue to perform well in anti-terrorism and conflict, while Middle Eastern countries tend to continue to rank behind because of domestic political instability and the threat of terrorism.

Europe European countries generally rank in the middle reaches of the world rankings, and none of them clearly rank among the top 30. The top 5 European countries in the field of counter-terrorism and conflict include Poland, Spain, Romania, Belarus and Germany. The reason why Poland ranks No. 1 in Europe is mainly due to its stable domestic environment and few terrorist attacks. While Western European countries are suffering from terrorist attacks, Poland has not had a terrorist attack for a long time. The Polish government and people hold a negative attitude towards accepting refugees and have a strong sense of guarding national borders, thus reducing the chance of many terrorists entering Poland. The last five European countries in the field of counter-terrorism and conflict are Iceland, Montenegro, Andorra, Monaco and San Marino. These countries are small in terms of population and land area, and are affected by our population weighting algorithm and, therefore, perform poorly in rankings. In terms of the absolute number of terrorist events and conflicts, there are not many terrorist attacks or conflicts in these countries, and they are peaceful and safe.

Western European and Nordic countries have performed poorly in counter-terrorism. In the twenty-first century, Western Europe has been an important target of extreme terrorist attacks. Two terrorist forces have emerged in Western Europe. The first force is Islamic extremism and religious fundamentalists. These people often have close ties with Al Qaeda, the Islamic State and other Islamic extremists and fundamentalists in the Middle East and North Africa. The 2004 Madrid train bombings in Spain and the 2005 London bombings that shocked the world are typical cases in this regard. The London bombing in the UK in 2005 greatly changed the thinking of European countries in response to the threat of terrorism. ${ }^{39}$ Such terrorist activities have been widely reported in the outside world, and they are also a main focus in Europe. The second force of terrorism is the indigenous Racially or Ethnically Motivated Terrorism (REMT). This type of terrorism is a terrorist attack against other races and ethnic groups launched by people with extreme hatred and desire to exclude. The 2011 bombings and shootings in Norway are typical cases of such terrorist activities. The 32-year-old Norwegian Anders Behring Breivik has

39 Coolsaet (2010). 
strong ideals of xenophobia and Christian terrorism. He meticulously prepared and carried out an explosion against a Norwegian government office building and shootings against hundreds of teenagers, which eventually caused a tragic f 69 deaths and 66 injuries. This terrorist attack was the largest attack that Norway had suffered since its invasion by Germany in World War II. Because this terrorist attack was planned by one person independently, it has also been called a lone-wolf terrorist attack. ${ }^{40}$ Lone-wolf terrorist attacks are proliferating in Europe and other regions, and they are a new serious challenge for the world's anti-terrorism efforts.

North America In 2018, among North American countries, the United States outperformed Canada in counter-terrorism and conflict. The United States has rapidly stepped up its crackdown on terrorist activities since the September 11 terrorist attacks in 2001. Bin Laden's Al Qaeda and the later rise of the Islamic State (ISIS), the two core Islamic terrorist forces, were basically eliminated by the United States. It is expected that Canada's performance in counter-terrorism and conflict is slightly worse than that of the United States. Canada has actively participated in US-led foreign wars and conflicts, but its performance in counter-terrorism has been weaker than that of the US. Therefore, Canada lags behind the United States in rankings. At the same time, the United States and Canada both face the threat of indigenous ethnic terrorism. But the United States may face more threats than Canada. ${ }^{41}$

Latin America In 2018, we found that the performance of Latin America was the same as that of Asia. The top five countries in the region are Brazil, Argentina, Cuba, Dominica and Peru, while the countries that lag behind are the small Caribbean countries such as Antigua and Barbuda, Dominica and Saint Kitts and Nevis. In the field of counter-terrorism and conflict, the regional powers of Latin America outperformed the small countries in the region. There are not many terrorist activities in Latin America as a whole, but the regional situation is not very peaceful either. There are armed conflicts and large-scale protests in countries such as Venezuela, Bolivia, Peru and Colombia. The internal situation of those small island countries that are lagging behind is not very stable, and because of the existence of population weighting factors, although they have not experienced many conflicts and terrorist attacks, they lag behind in relative terms.

Africa In 2018, we found that the top 5 African countries were Ethiopia, Eritrea, South Sudan, Angola and Tanzania. These countries are also among the highest in the world rankings in the field of counter-terrorism and conflict. Ethiopia, Eritrea, and South Sudan were able to rank in the top 3 mainly because of the peace agreements they have signed, which ended past conflicts. Compared with other regions, the security situation in Africa is relatively unstable and there are more variables. Take Ethiopia as an example: although the country ranked first in the world and Africa in 2018, its ranking was out of top 20 before 2014. In 2020, conflicts between the federal government and local state governments broke out in Ethiopia, causing hundreds of casualties. If the situation is not effectively controlled, Ethiopia's latest ranking will drop significantly in future. The situation in Ethiopia is a relatively

\footnotetext{
40 Appleton (2014).

41 Taylor (2019).
} 
common phenomenon in African countries. Although Africa is also facing the threat of terrorism, on the whole, it is the internal conflict and security situation that affects the performance of African countries in the field of counter-terrorism and conflict. Conflicts caused by ethnic, cultural, religious, resource and territorial issues are likely to plague African countries for a long time.

Oceania In 2018, we found that the top 3 countries in Oceania are Australia, Papua New Guinea and New Zealand. At the bottom of the ranking are small island countries such as Palau, Nauru, and Tuvalu. Oceanian countries such as Australia and New Zealand have long given the outside world the impression of being very harmonious and stable. But in recent years, the threat of terrorism has also shown an upward trend in the region. Terrorist attacks carried out by Islamic extremists in Europe and terrorist attacks caused by indigenous racism and xenophobia have also appeared in countries such as Australia and New Zealand. For example, in March 2019, the Christchurch Mosque shooting occurred in New Zealand. The incident resulted in 51 deaths and 49 injuries, shocking the world. New Zealand is a country that allows citizens to own guns, and gun controls are relatively light. Although the New Zealand shooting in 2019 was not included in our research, this terrorist act is similar to the shooting carried out by the Norwegian Anders Behring Breivik, and belongs to the homegrown category of racially and ethnically motivated terrorism. Both New Zealand and Australia are countries that welcome refugees, and refugee policy has become a major issue within these countries. If it is not handled properly, it may trigger more terrorist attacks.

\subsubsection{Conclusion}

Terrorism and conflicts have deep religious, ideological and cultural roots, ${ }^{42}$ so it is difficult to eliminate them in a short time. Both developed and developing countries will face long-term threats from terrorism and conflict. The terrorist threat caused by Islamic extremism will continue to pose a major threat to Europe and North America in the short term. At the same time, local racial and ethnically driven terrorism may develop further. In the context of xenophobia, racial hatred and antiglobalization sentiments, the developmental momentum of indigenous terrorism may surpass Islamic terrorism. Regional and internal conflicts are also issues that need to be focused on in the future. In the context of the raging novel coronavirus pandemic, the gap between rich and poor and social conflicts may be further widened and intensified, which will cause more regional conflicts and domestic social conflicts. In recent years, some countries in Latin America have faced intensified internal conflicts. The "Black Lives Matter" movement in the United States has also caused many conflicts and confrontations in the country. In the future, these issues may further ferment and affect more countries.

${ }^{42}$ Hoffman (1995). 


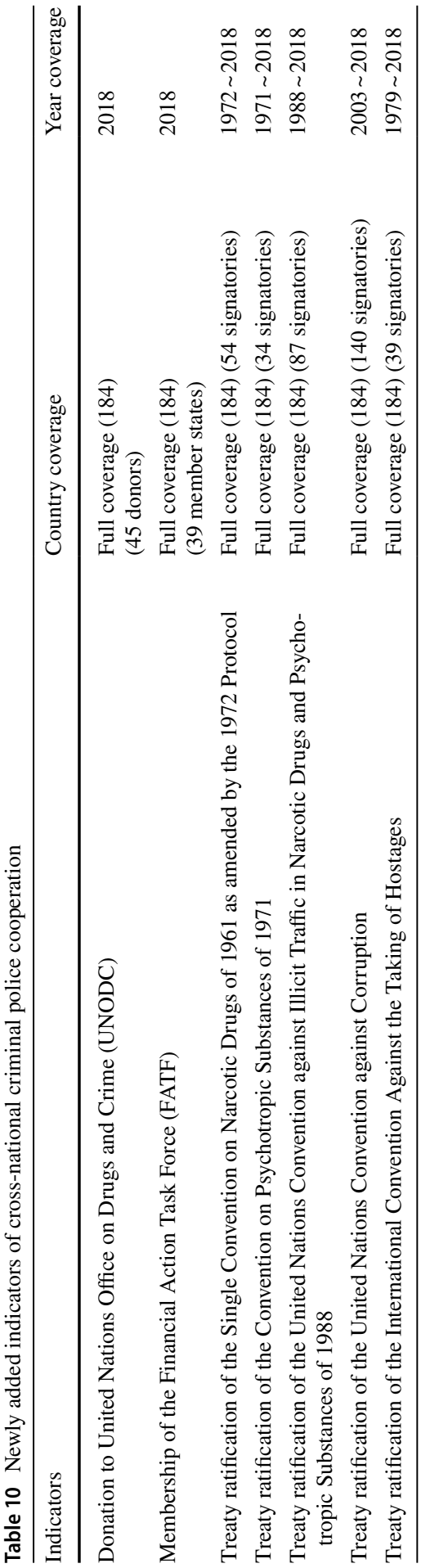




\subsection{Issue 5: Cross-national Criminal Police Cooperation}

\subsubsection{Introduction}

Transnational crimes, i.e. crimes that involve more than one country in their planning and organization and have effects across national borders, has been called "the dark side of globalization". ${ }^{43}$ Taking advantage of economic liberalization, technological progress and the freer movement of money, goods and services, "profitdriven crime (e.g., money laundering, drug trafficking, gaming and the sex trade) responds-much like legitimate economic activity-to local regulation by shifting to the territorial jurisdictions in which it incurs lower expected sanctions, making it most profitable for criminals". ${ }^{44}$ As a response to the explosive growth of transnational crime, there is increasing cooperation and collaboration between national governments and organizations to combat transnational crime, which has resulted in the rise of the international legal field of global crime control. ${ }^{45}$ However, different national governments react to the international mobility of criminal activities differently. Broude and Teichman distinguish between two types of transnational crime that relate to different incentives of the government to adopt control policies. The first type is "insourcing crime", "whose production process might carry economic benefits so that some national governments have an incentive to adopt lenient crime control policies towards [those crimes]"; the other one is "outsourcing crime", which are those crimes "the jurisdictions will perceive as harmful" and "undesirable" and thus adopt "harsher sanctions at the domestic level" ${ }^{46}$ However, because of the suggested cross-national harm to citizens, transnational crimes have caused serious challenges to global justice, and we argue that it is the obligation of national governments to facilitate international cooperation to combat criminal activities no matter whether these activities are insourcing crime or outsourcing crime. Fighting transnational crimes is a major domain of global cooperation to improve global justice. As a result, we include this issue in our global justice index and measure each country's contributions to fighting transnational crimes. In the following sections we elaborate our indicators, methods and results.

\subsubsection{Dimensions and Indicators}

Last year, we used two major categories to measure transnational criminal cooperation, and each comprised several indicators. The first category, contribution, measures financial contribution to Interpol (the International Criminal Police Organization), and the second category, performance, is the ratification status of each country of UN treaties relating to cooperation against transnational crime. This year, we added seven new indicators to refine the index. First, we make the measurement of

\footnotetext{
43 Heine \& Thakur (2011).

44 Broude \& Teichman (2009).

45 Andreas \& Nadelmann (2008).

${ }^{46}$ Broude \& Teichman (2009).
} 


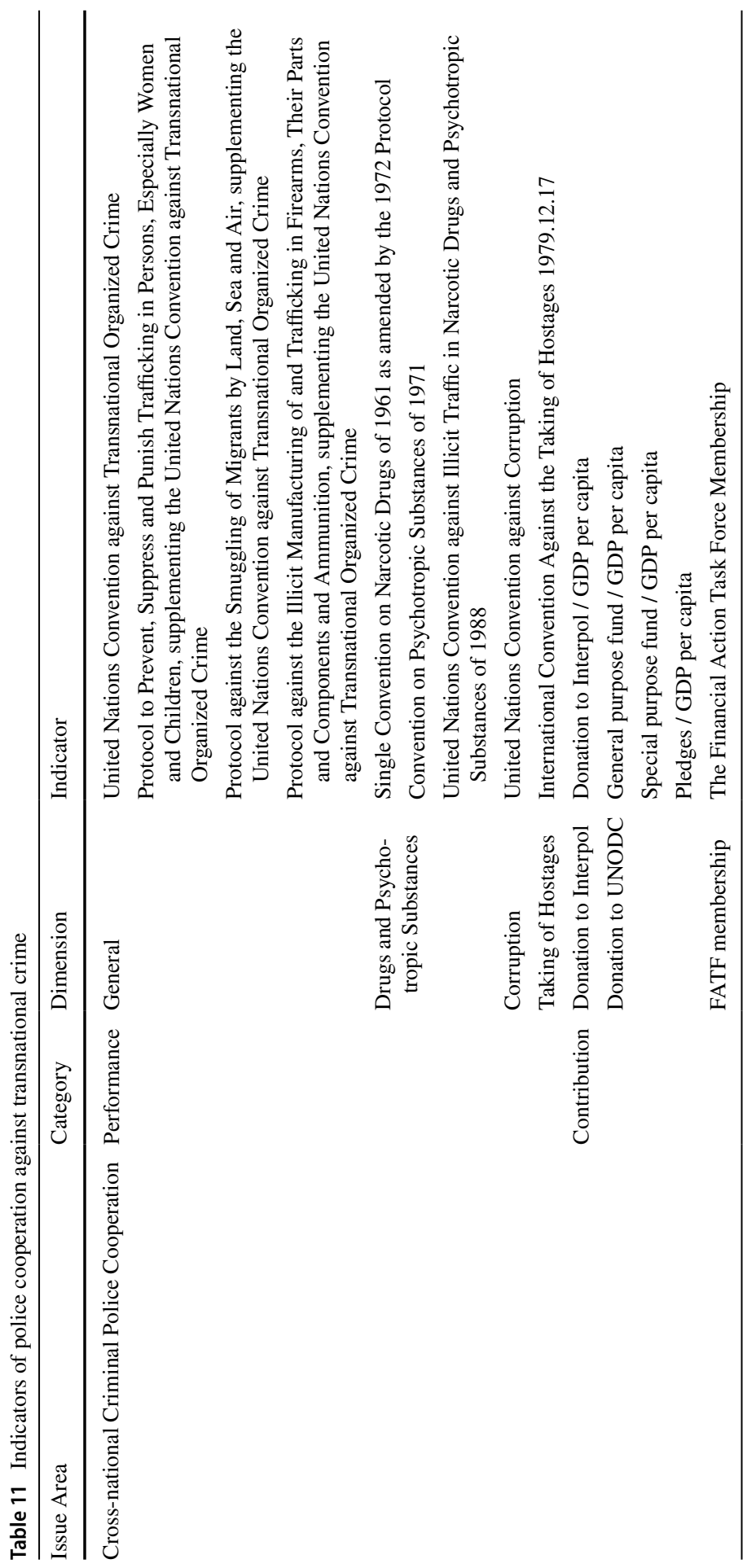


Table 12 Country ranking in police cooperation against transnational crime (version 1)

\begin{tabular}{|c|c|c|c|c|c|c|c|c|c|}
\hline Country & 2010 & 2011 & 2012 & 2013 & 2014 & 2015 & 2016 & 2017 & 2018 \\
\hline United States of America & 1 & 1 & 1 & 1 & 1 & 1 & 1 & 1 & 1 \\
\hline Japan & 5 & 5 & 3 & 2 & 2 & 2 & 2 & 2 & 2 \\
\hline Germany & 2 & 2 & 2 & 3 & 3 & 3 & 3 & 3 & 3 \\
\hline $\begin{array}{l}\text { United Kingdom of Great Britain } \\
\text { and Northern Ireland }\end{array}$ & 4 & 4 & 4 & 4 & 4 & 6 & 5 & 5 & 4 \\
\hline Sweden & 9 & 11 & 10 & 10 & 11 & 14 & 15 & 15 & 5 \\
\hline Belgium & 12 & 14 & 14 & 16 & 16 & 17 & 20 & 20 & 6 \\
\hline Italy & 6 & 6 & 6 & 6 & 5 & 4 & 6 & 6 & 7 \\
\hline Greece & 42 & 12 & 11 & 11 & 10 & 12 & 13 & 14 & 8 \\
\hline Finland & 13 & 15 & 15 & 17 & 17 & 18 & 18 & 19 & 9 \\
\hline New Zealand & 18 & 19 & 21 & 22 & 20 & 23 & 21 & 22 & 10 \\
\hline Brazil & 11 & 13 & 13 & 13 & 13 & 9 & 7 & 7 & 11 \\
\hline Norway & 22 & 24 & 26 & 26 & 26 & 26 & 27 & 27 & 12 \\
\hline Luxembourg & 41 & 43 & 32 & 33 & 33 & 32 & 32 & 30 & 13 \\
\hline Canada & 16 & 17 & 16 & 15 & 15 & 16 & 16 & 16 & 14 \\
\hline China & 3 & 3 & 5 & 5 & 6 & 5 & 4 & 4 & 15 \\
\hline France & 8 & 8 & 8 & 8 & 8 & 8 & 9 & 9 & 16 \\
\hline India & 17 & 7 & 7 & 7 & 7 & 7 & 8 & 8 & 17 \\
\hline Netherlands & 20 & 20 & 20 & 20 & 21 & 22 & 24 & 25 & 18 \\
\hline Austria & 23 & 25 & 25 & 25 & 28 & 28 & 29 & 32 & 19 \\
\hline Portugal & 30 & 32 & 30 & 30 & 29 & 30 & 30 & 31 & 20 \\
\hline Switzerland & 26 & 28 & 29 & 31 & 32 & 33 & 33 & 33 & 21 \\
\hline Turkey & 29 & 31 & 33 & 34 & 34 & 27 & 26 & 21 & 22 \\
\hline Russian Federation & 25 & 33 & 34 & 29 & 25 & 11 & 10 & 10 & 23 \\
\hline Israel & 34 & 36 & 37 & 37 & 38 & 40 & 40 & 40 & 24 \\
\hline Argentina & 21 & 27 & 28 & 28 & 31 & 35 & 36 & 39 & 25 \\
\hline Australia & 35 & 38 & 39 & 39 & 39 & 37 & 37 & 37 & 26 \\
\hline Mexico & 28 & 22 & 19 & 14 & 14 & 13 & 12 & 13 & 27 \\
\hline Spain & 31 & 29 & 23 & 21 & 23 & 21 & 23 & 24 & 28 \\
\hline Denmark & 45 & 46 & 47 & 48 & 48 & 49 & 50 & 48 & 29 \\
\hline Indonesia & 44 & 45 & 45 & 44 & 41 & 38 & 38 & 35 & 30 \\
\hline Egypt & 10 & 10 & 12 & 12 & 12 & 15 & 14 & 11 & 31 \\
\hline Togo & 7 & 9 & 9 & 9 & 9 & 10 & 11 & 12 & 32 \\
\hline Chile & 15 & 18 & 18 & 19 & 18 & 19 & 17 & 17 & 33 \\
\hline Republic of Korea & 101 & 93 & 91 & 87 & 95 & 44 & 45 & 47 & 34 \\
\hline South Africa & 59 & 59 & 59 & 54 & 53 & 50 & 52 & 54 & 35 \\
\hline Philippines & 14 & 16 & 17 & 18 & 19 & 20 & 19 & 18 & 36 \\
\hline Senegal & 19 & 21 & 22 & 23 & 22 & 24 & 22 & 23 & 37 \\
\hline Guatemala & 24 & 26 & 27 & 27 & 27 & 29 & 28 & 28 & 38 \\
\hline Panama & 27 & 30 & 31 & 32 & 30 & 31 & 31 & 29 & 39 \\
\hline Haiti & 57 & 23 & 24 & 24 & 24 & 25 & 25 & 26 & 40 \\
\hline Saudi Arabia & 82 & 83 & 87 & 84 & 86 & 85 & 83 & 84 & 41 \\
\hline Honduras & 33 & 35 & 36 & 36 & 35 & 36 & 35 & 34 & 42 \\
\hline
\end{tabular}


Table 12 (continued)

\begin{tabular}{|c|c|c|c|c|c|c|c|c|c|}
\hline Country & 2010 & 2011 & 2012 & 2013 & 2014 & 2015 & 2016 & 2017 & 2018 \\
\hline Jamaica & 36 & 37 & 38 & 38 & 37 & 39 & 39 & 38 & 43 \\
\hline Malaysia & 100 & 103 & 102 & 101 & 102 & 102 & 101 & 100 & 44 \\
\hline Mauritius & 37 & 39 & 40 & 40 & 40 & 41 & 41 & 41 & 45 \\
\hline Ireland & 106 & 106 & 107 & 108 & 111 & 116 & 120 & 121 & 46 \\
\hline Gabon & 40 & 42 & 43 & 45 & 44 & 42 & 43 & 42 & 47 \\
\hline Lesotho & 43 & 44 & 44 & 42 & 42 & 43 & 42 & 43 & 48 \\
\hline Ghana & 96 & 102 & 46 & 50 & 47 & 48 & 48 & 46 & 49 \\
\hline Bolivia (Plurinational State of) & 46 & 48 & 50 & 52 & 51 & 51 & 53 & 51 & 50 \\
\hline El Salvador & 48 & 50 & 51 & 53 & 52 & 53 & 55 & 53 & 51 \\
\hline Paraguay & 50 & 52 & 52 & 56 & 54 & 57 & 56 & 56 & 52 \\
\hline Dominican Republic & 51 & 51 & 53 & 55 & 55 & 58 & 57 & 57 & 53 \\
\hline Costa Rica & 52 & 53 & 56 & 59 & 57 & 59 & 58 & 59 & 54 \\
\hline Poland & 32 & 34 & 35 & 35 & 36 & 34 & 34 & 36 & 55 \\
\hline Liberia & 38 & 41 & 42 & 43 & 43 & 45 & 44 & 44 & 56 \\
\hline Singapore & 143 & 145 & 147 & 147 & 149 & 142 & 142 & 142 & 57 \\
\hline Ukraine & 58 & 60 & 63 & 65 & 62 & 55 & 54 & 55 & 58 \\
\hline Hungary & 53 & 55 & 55 & 58 & 60 & 60 & 59 & 60 & 59 \\
\hline Peru & 56 & 57 & 60 & 61 & 63 & 63 & 62 & 61 & 60 \\
\hline Nicaragua & 54 & 56 & 58 & 60 & 61 & 62 & 63 & 64 & 61 \\
\hline Cote d'Ivoire & 123 & 114 & 73 & 76 & 79 & 84 & 84 & 62 & 62 \\
\hline Tunisia & 61 & 61 & 65 & 66 & 66 & 65 & 66 & 65 & 63 \\
\hline Belarus & 63 & 64 & 67 & 68 & 69 & 67 & 67 & 69 & 64 \\
\hline Ecuador & 62 & 62 & 66 & 67 & 67 & 68 & 69 & 71 & 65 \\
\hline Trinidad and Tobago & 64 & 65 & 69 & 70 & 71 & 70 & 71 & 73 & 66 \\
\hline Cyprus & 65 & 66 & 70 & 71 & 70 & 69 & 72 & 75 & 67 \\
\hline Colombia & 95 & 101 & 103 & 104 & 104 & 96 & 93 & 93 & 68 \\
\hline Afghanistan & 89 & 88 & 92 & 85 & 73 & 73 & 75 & 52 & 69 \\
\hline Madagascar & 49 & 49 & 48 & 47 & 46 & 46 & 47 & 50 & 70 \\
\hline Sierra Leone & 102 & 99 & 105 & 120 & 56 & 52 & 51 & 49 & 71 \\
\hline Democratic Republic of the Congo & 39 & 40 & 41 & 41 & 45 & 47 & 46 & 45 & 72 \\
\hline Sudan & 126 & 124 & 123 & 124 & 101 & 105 & 100 & 94 & 73 \\
\hline Rwanda & 55 & 54 & 57 & 57 & 59 & 61 & 61 & 63 & 74 \\
\hline Nigeria & 73 & 73 & 76 & 78 & 78 & 77 & 70 & 66 & 75 \\
\hline United Republic of Tanzania & 60 & 58 & 61 & 64 & 64 & 64 & 68 & 72 & 76 \\
\hline Algeria & 74 & 75 & 77 & 77 & 77 & 74 & 73 & 74 & 77 \\
\hline Uganda & 66 & 63 & 64 & 63 & 65 & 66 & 65 & 67 & 78 \\
\hline Cameroon & 69 & 69 & 71 & 72 & 74 & 71 & 76 & 76 & 79 \\
\hline Zambia & 72 & 72 & 74 & 75 & 75 & 72 & 74 & 77 & 80 \\
\hline Kuwait & 79 & 81 & 85 & 88 & 87 & 87 & 86 & 82 & 81 \\
\hline Cuba & 128 & 129 & 132 & 83 & 85 & 86 & 87 & 85 & 82 \\
\hline Suriname & 81 & 80 & 84 & 89 & 90 & 89 & 88 & 86 & 83 \\
\hline Bulgaria & 78 & 79 & 83 & 86 & 88 & 88 & 89 & 87 & 84 \\
\hline
\end{tabular}


Table 12 (continued)

\begin{tabular}{|c|c|c|c|c|c|c|c|c|c|}
\hline Country & 2010 & 2011 & 2012 & 2013 & 2014 & 2015 & 2016 & 2017 & 2018 \\
\hline Uruguay & 80 & 82 & 86 & 90 & 92 & 90 & 90 & 90 & 85 \\
\hline Bahrain & 83 & 84 & 90 & 93 & 94 & 92 & 91 & 91 & 86 \\
\hline Morocco & 97 & 76 & 82 & 82 & 82 & 82 & 81 & 80 & 87 \\
\hline Malawi & 68 & 67 & 54 & 46 & 50 & 56 & 49 & 58 & 88 \\
\hline Jordan & 84 & 85 & 89 & 92 & 93 & 93 & 92 & 92 & 89 \\
\hline Pakistan & 71 & 70 & 72 & 69 & 72 & 76 & 77 & 78 & 90 \\
\hline Central African Republic & 70 & 68 & 68 & 51 & 58 & 54 & 60 & 68 & 91 \\
\hline Mozambique & 67 & 71 & 75 & 73 & 76 & 75 & 64 & 70 & 92 \\
\hline Ethiopia & 98 & 89 & 62 & 62 & 68 & 78 & 80 & 83 & 93 \\
\hline Burkina Faso & 75 & 77 & 80 & 80 & 81 & 79 & 78 & 81 & 94 \\
\hline Mali & 77 & 78 & 81 & 81 & 83 & 81 & 85 & 88 & 95 \\
\hline Guinea & 76 & 74 & 78 & 79 & 80 & 83 & 82 & 89 & 96 \\
\hline Myanmar & 88 & 92 & 95 & 94 & 97 & 98 & 99 & 98 & 97 \\
\hline Timor-Leste & 85 & 86 & 88 & 95 & 96 & 99 & 102 & 99 & 98 \\
\hline Benin & 90 & 91 & 94 & 97 & 99 & 94 & 94 & 95 & 99 \\
\hline Kyrgyzstan & 86 & 90 & 96 & 98 & 98 & 95 & 97 & 96 & 100 \\
\hline Czechia & 138 & 142 & 142 & 99 & 91 & 91 & 95 & 97 & 101 \\
\hline Kenya & 87 & 87 & 93 & 96 & 100 & 100 & 103 & 103 & 102 \\
\hline Sao Tome and Principe & 91 & 94 & 97 & 100 & 103 & 104 & 104 & 104 & 103 \\
\hline Libya & 105 & 97 & 109 & 107 & 106 & 97 & 96 & 101 & 104 \\
\hline Slovakia & 93 & 100 & 100 & 105 & 108 & 106 & 106 & 108 & 105 \\
\hline Lao People's Democratic Republic & 92 & 95 & 101 & 103 & 105 & 107 & 107 & 107 & 106 \\
\hline Romania & 110 & 110 & 111 & 115 & 117 & 110 & 108 & 106 & 107 \\
\hline Djibouti & 99 & 98 & 99 & 106 & 109 & 108 & 109 & 110 & 108 \\
\hline Angola & 151 & 154 & 154 & 148 & 120 & 118 & 116 & 118 & 109 \\
\hline Cabo Verde & 108 & 108 & 108 & 110 & 112 & 111 & 112 & 112 & 110 \\
\hline Iraq & 114 & 116 & 119 & 122 & 124 & 117 & 113 & 111 & 111 \\
\hline Azerbaijan & 117 & 118 & 120 & 123 & 125 & 122 & 114 & 114 & 112 \\
\hline Mongolia & 104 & 109 & 113 & 113 & 115 & 114 & 118 & 115 & 113 \\
\hline Eswatini & 152 & 153 & 114 & 112 & 114 & 113 & 115 & 117 & 114 \\
\hline Armenia & 107 & 107 & 110 & 111 & 113 & 112 & 117 & 116 & 115 \\
\hline Republic of Moldova & 103 & 105 & 106 & 109 & 110 & 109 & 110 & 113 & 116 \\
\hline Albania & 111 & 111 & 112 & 114 & 116 & 115 & 119 & 119 & 117 \\
\hline Croatia & 118 & 119 & 122 & 125 & 126 & 125 & 125 & 120 & 118 \\
\hline Namibia & 115 & 115 & 117 & 119 & 121 & 121 & 121 & 122 & 119 \\
\hline Republic of North Macedonia & 112 & 112 & 115 & 118 & 122 & 120 & 124 & 125 & 120 \\
\hline Bosnia and Herzegovina & 113 & 113 & 116 & 117 & 119 & 119 & 122 & 124 & 121 \\
\hline Serbia & 116 & 117 & 118 & 121 & 123 & 123 & 123 & 123 & 122 \\
\hline Lithuania & 121 & 123 & 126 & 129 & 130 & 128 & 127 & 126 & 123 \\
\hline Latvia & 120 & 122 & 125 & 128 & 128 & 127 & 128 & 127 & 124 \\
\hline Seychelles & 119 & 120 & 124 & 127 & 127 & 129 & 129 & 128 & 125 \\
\hline Barbados & 165 & 164 & 167 & 167 & 129 & 130 & 130 & 129 & 126 \\
\hline
\end{tabular}


Table 12 (continued)

\begin{tabular}{|c|c|c|c|c|c|c|c|c|c|}
\hline Country & 2010 & 2011 & 2012 & 2013 & 2014 & 2015 & 2016 & 2017 & 2018 \\
\hline Malta & 122 & 125 & 127 & 130 & 132 & 131 & 131 & 130 & 127 \\
\hline Monaco & 124 & 126 & 128 & 131 & 133 & 132 & 132 & 132 & 128 \\
\hline Iceland & 172 & 171 & 172 & 175 & 175 & 175 & 175 & 176 & 129 \\
\hline Yemen & 125 & 121 & 121 & 126 & 131 & 126 & 111 & 105 & 130 \\
\hline Lebanon & 129 & 130 & 133 & 136 & 138 & 136 & 136 & 134 & 131 \\
\hline Brunei Darussalam & 130 & 131 & 134 & 137 & 139 & 138 & 137 & 137 & 132 \\
\hline Thailand & 139 & 139 & 143 & 116 & 118 & 124 & 126 & 131 & 133 \\
\hline Zimbabwe & 131 & 132 & 136 & 133 & 135 & 133 & 133 & 133 & 134 \\
\hline Niger & 109 & 104 & 104 & 102 & 107 & 103 & 105 & 109 & 135 \\
\hline Viet Nam & 146 & 146 & 131 & 135 & 137 & 135 & 135 & 135 & 136 \\
\hline United Arab Emirates & 132 & 133 & 135 & 138 & 142 & 139 & 139 & 138 & 137 \\
\hline Sri Lanka & 140 & 143 & 145 & 145 & 146 & 141 & 140 & 140 & 138 \\
\hline Qatar & 134 & 136 & 139 & 142 & 144 & 145 & 144 & 144 & 139 \\
\hline Cambodia & 127 & 128 & 130 & 134 & 136 & 137 & 138 & 139 & 140 \\
\hline Mauritania & 133 & 134 & 137 & 140 & 141 & 140 & 141 & 141 & 141 \\
\hline Burundi & 145 & 141 & 79 & 74 & 84 & 101 & 98 & 102 & 142 \\
\hline Nepal & 136 & 127 & 129 & 132 & 134 & 134 & 134 & 136 & 143 \\
\hline Guyana & 137 & 137 & 141 & 143 & 145 & 146 & 147 & 146 & 144 \\
\hline Comoros & 135 & 135 & 138 & 141 & 143 & 143 & 143 & 143 & 145 \\
\hline Bahamas & 142 & 144 & 146 & 146 & 147 & 148 & 148 & 148 & 146 \\
\hline Gambia & 144 & 138 & 140 & 139 & 140 & 144 & 145 & 145 & 147 \\
\hline Tajikistan & 141 & 140 & 144 & 144 & 148 & 147 & 146 & 147 & 148 \\
\hline Kazakhstan & 161 & 162 & 164 & 166 & 166 & 162 & 153 & 153 & 149 \\
\hline Papua New Guinea & 147 & 148 & 151 & 152 & 152 & 150 & 151 & 150 & 150 \\
\hline Bhutan & 149 & 149 & 150 & 151 & 151 & 151 & 152 & 151 & 151 \\
\hline Georgia & 150 & 151 & 152 & 154 & 155 & 153 & 154 & 154 & 152 \\
\hline Belize & 153 & 152 & 153 & 153 & 154 & 154 & 155 & 155 & 153 \\
\hline Oman & 159 & 160 & 161 & 163 & 163 & 156 & 156 & 156 & 154 \\
\hline Fiji & 179 & 182 & 182 & 185 & 185 & 184 & 183 & 157 & 155 \\
\hline Turkmenistan & 154 & 155 & 157 & 160 & 160 & 157 & 157 & 158 & 156 \\
\hline Saint Vincent and the Grenadines & 155 & 156 & 155 & 156 & 156 & 160 & 159 & 159 & 157 \\
\hline Dominica & 181 & 184 & 184 & 157 & 157 & 164 & 163 & 160 & 158 \\
\hline Botswana & 156 & 159 & 158 & 159 & 159 & 159 & 161 & 163 & 159 \\
\hline Slovenia & 160 & 161 & 160 & 162 & 161 & 163 & 160 & 161 & 160 \\
\hline Montenegro & 157 & 158 & 156 & 158 & 158 & 158 & 158 & 162 & 161 \\
\hline Nauru & 180 & 183 & 162 & 164 & 164 & 161 & 162 & 164 & 162 \\
\hline Maldives & 174 & 175 & 175 & 173 & 172 & 171 & 164 & 165 & 163 \\
\hline Grenada & 158 & 157 & 159 & 161 & 162 & 165 & 165 & 166 & 164 \\
\hline Estonia & 163 & 166 & 168 & 169 & 169 & 167 & 168 & 168 & 165 \\
\hline Antigua and Barbuda & 162 & 163 & 165 & 165 & 167 & 166 & 167 & 167 & 166 \\
\hline Saint Kitts and Nevis & 164 & 165 & 166 & 168 & 168 & 168 & 169 & 169 & 167 \\
\hline San Marino & 166 & 167 & 169 & 170 & 170 & 169 & 170 & 170 & 168 \\
\hline
\end{tabular}


Table 12 (continued)

\begin{tabular}{llllllllll}
\hline Country & 2010 & 2011 & 2012 & 2013 & 2014 & 2015 & 2016 & 2017 & 2018 \\
\hline Kiribati & 167 & 168 & 170 & 171 & 171 & 170 & 171 & 171 & 169 \\
Bangladesh & 169 & 147 & 149 & 150 & 153 & 155 & 166 & 172 & 170 \\
Chad & 168 & 169 & 163 & 155 & 165 & 152 & 150 & 149 & 171 \\
Guinea-Bissau & 148 & 150 & 148 & 149 & 150 & 149 & 149 & 152 & 172 \\
Uzbekistan & 170 & 170 & 171 & 172 & 173 & 172 & 172 & 173 & 173 \\
Equatorial Guinea & 173 & 173 & 173 & 176 & 176 & 174 & 173 & 174 & 174 \\
Saint Lucia & 182 & 185 & 185 & 174 & 174 & 173 & 174 & 175 & 175 \\
Micronesia (Federated States of) & 175 & 174 & 174 & 177 & 177 & 176 & 176 & 177 & 176 \\
Marshall Islands & 177 & 176 & 176 & 178 & 178 & 177 & 177 & 178 & 177 \\
Samoa & 184 & 180 & 181 & 183 & 179 & 178 & 179 & 180 & 178 \\
Tonga & 178 & 181 & 183 & 184 & 180 & 179 & 178 & 179 & 179 \\
Andorra & 183 & 177 & 178 & 179 & 182 & 181 & 180 & 181 & 180 \\
Vanuatu & 175 & 178 & 179 & 180 & 183 & 182 & 181 & 182 & 181 \\
Congo & 176 & 179 & 180 & 182 & 184 & 183 & 182 & 183 & 182 \\
Tuvalu & 184 & 186 & 186 & 186 & 186 & 185 & 184 & 184 & 183 \\
Solomon Islands & 184 & 186 & 186 & 186 & 186 & 185 & 184 & 184 & 183 \\
Palau & 184 & 186 & 186 & 186 & 186 & 185 & 184 & 184 & 183 \\
Venezuela (Bolivarian Republic of) & 47 & 47 & 49 & 49 & 49 & NA & NA & NA & NA \\
South Sudan & 184 & 186 & 177 & 181 & 181 & 180 & NA & NA & NA \\
Eritrea & 171 & 172 & NA & NA & NA & NA & NA & NA & NA \\
Iran (Islamic Republic of) & 94 & 96 & 98 & 91 & 89 & 80 & 79 & 79 & NA \\
\hline & & & & & & & &
\end{tabular}

performance more detailed: instead of focusing merely on the general UN treaties, we examine various types of criminal activities, including drug trafficking, corruption and hostage-taking. Second, we extend the measurement of contribution by including donations to UNODC (United Nations Office on Drugs and Crime) and FATF (Financial Action Task Force) membership, in addition to the initial calculation of donations to Interpol. A summary of the newly added indicators is given below (Table 10).

As a result, we now have 14 indicators in all. For the performance category, we measure the ratification status of each country to the UN treaties. These treaties include general treaties against transnational organized crime (United Nations Convention against Transnational Organized Crime, Protocol to Prevent, Suppress and Punish Trafficking in Persons, Especially Women and Children, supplementing the United Nations Convention against Transnational Organized Crime, Protocol against the Smuggling of Migrants by Land, Sea and Air, supplementing the United Nations Convention against Transnational Organized Crime, Protocol against the Illicit Manufacturing of and Trafficking in Firearms, Their Parts and Components and Ammunition, supplementing the United Nations Convention against Transnational Organized Crime), treaties against drugs and psychotropic substances (Single Convention on Narcotic Drugs of 1961 as amended by the 1972 Protocol, Convention on Psychotropic Substances of 1971, United Nations Convention against Illicit 
Table 13 Country ranking in police cooperation against transnational crime (version 2)

\begin{tabular}{|c|c|c|c|c|c|c|c|c|c|}
\hline Country & 2010 & 2011 & 2012 & 2013 & 2014 & 2015 & 2016 & 2017 & 2018 \\
\hline United States of America & 1 & 1 & 1 & 1 & 1 & 1 & 1 & 1 & 1 \\
\hline Japan & 5 & 5 & 3 & 2 & 2 & 2 & 2 & 2 & 2 \\
\hline Germany & 2 & 2 & 2 & 3 & 3 & 3 & 3 & 3 & 3 \\
\hline China & 3 & 3 & 5 & 5 & 6 & 5 & 4 & 4 & 4 \\
\hline $\begin{array}{l}\text { United Kingdom of Great Britain } \\
\text { and Northern Ireland }\end{array}$ & 4 & 4 & 4 & 4 & 4 & 6 & 5 & 5 & 5 \\
\hline Brazil & 11 & 13 & 13 & 13 & 13 & 9 & 7 & 7 & 6 \\
\hline Italy & 6 & 6 & 6 & 6 & 5 & 4 & 6 & 6 & 7 \\
\hline India & 17 & 7 & 7 & 7 & 7 & 7 & 8 & 8 & 8 \\
\hline France & 8 & 8 & 8 & 8 & 8 & 8 & 9 & 9 & 9 \\
\hline Russian Federation & 25 & 33 & 34 & 29 & 25 & 11 & 10 & 10 & 10 \\
\hline Egypt & 10 & 10 & 12 & 12 & 12 & 15 & 14 & 11 & 11 \\
\hline Togo & 7 & 9 & 9 & 9 & 9 & 10 & 11 & 12 & 12 \\
\hline Mexico & 28 & 22 & 19 & 14 & 14 & 13 & 12 & 13 & 13 \\
\hline Greece & 42 & 12 & 11 & 11 & 10 & 12 & 13 & 14 & 14 \\
\hline Sweden & 9 & 11 & 10 & 10 & 11 & 14 & 15 & 15 & 15 \\
\hline Turkey & 29 & 31 & 33 & 34 & 34 & 27 & 26 & 21 & 16 \\
\hline Canada & 16 & 17 & 16 & 15 & 15 & 16 & 16 & 16 & 17 \\
\hline Philippines & 14 & 16 & 17 & 18 & 19 & 20 & 19 & 18 & 18 \\
\hline Chile & 15 & 18 & 18 & 19 & 18 & 19 & 17 & 17 & 19 \\
\hline Finland & 13 & 15 & 15 & 17 & 17 & 18 & 18 & 19 & 20 \\
\hline Belgium & 12 & 14 & 14 & 16 & 16 & 17 & 20 & 20 & 21 \\
\hline New Zealand & 18 & 19 & 21 & 22 & 20 & 23 & 21 & 22 & 22 \\
\hline Senegal & 19 & 21 & 22 & 23 & 22 & 24 & 22 & 23 & 23 \\
\hline Spain & 31 & 29 & 23 & 21 & 23 & 21 & 23 & 24 & 24 \\
\hline Netherlands & 20 & 20 & 20 & 20 & 21 & 22 & 24 & 25 & 25 \\
\hline Haiti & 57 & 23 & 24 & 24 & 24 & 25 & 25 & 26 & 26 \\
\hline Norway & 22 & 24 & 26 & 26 & 26 & 26 & 27 & 27 & 27 \\
\hline Guatemala & 24 & 26 & 27 & 27 & 27 & 29 & 28 & 28 & 28 \\
\hline Panama & 27 & 30 & 31 & 32 & 30 & 31 & 31 & 29 & 29 \\
\hline Luxembourg & 41 & 43 & 32 & 33 & 33 & 32 & 32 & 30 & 30 \\
\hline Austria & 23 & 25 & 25 & 25 & 28 & 28 & 29 & 32 & 31 \\
\hline Portugal & 30 & 32 & 30 & 30 & 29 & 30 & 30 & 31 & 32 \\
\hline Switzerland & 26 & 28 & 29 & 31 & 32 & 33 & 33 & 33 & 33 \\
\hline Argentina & 21 & 27 & 28 & 28 & 31 & 35 & 36 & 39 & 34 \\
\hline Indonesia & 44 & 45 & 45 & 44 & 41 & 38 & 38 & 35 & 35 \\
\hline Honduras & 33 & 35 & 36 & 36 & 35 & 36 & 35 & 34 & 36 \\
\hline Poland & 32 & 34 & 35 & 35 & 36 & 34 & 34 & 36 & 37 \\
\hline Australia & 35 & 38 & 39 & 39 & 39 & 37 & 37 & 37 & 38 \\
\hline Jamaica & 36 & 37 & 38 & 38 & 37 & 39 & 39 & 38 & 39 \\
\hline Israel & 34 & 36 & 37 & 37 & 38 & 40 & 40 & 40 & 40 \\
\hline Mauritius & 37 & 39 & 40 & 40 & 40 & 41 & 41 & 41 & 41 \\
\hline Liberia & 38 & 41 & 42 & 43 & 43 & 45 & 44 & 44 & 42 \\
\hline
\end{tabular}


Table 13 (continued)

\begin{tabular}{|c|c|c|c|c|c|c|c|c|c|}
\hline Country & 2010 & 2011 & 2012 & 2013 & 2014 & 2015 & 2016 & 2017 & 2018 \\
\hline Gabon & 40 & 42 & 43 & 45 & 44 & 42 & 43 & 42 & 43 \\
\hline Lesotho & 43 & 44 & 44 & 42 & 42 & 43 & 42 & 43 & 44 \\
\hline Republic of Korea & 101 & 93 & 91 & 87 & 95 & 44 & 45 & 47 & 45 \\
\hline Afghanistan & 89 & 88 & 92 & 85 & 73 & 73 & 75 & 52 & 46 \\
\hline Madagascar & 49 & 49 & 48 & 47 & 46 & 46 & 47 & 50 & 47 \\
\hline Sierra Leone & 102 & 99 & 105 & 120 & 56 & 52 & 51 & 49 & 48 \\
\hline Ghana & 96 & 102 & 46 & 50 & 47 & 48 & 48 & 46 & 49 \\
\hline Denmark & 45 & 46 & 47 & 48 & 48 & 49 & 50 & 48 & 50 \\
\hline Democratic Republic of the Congo & 39 & 40 & 41 & 41 & 45 & 47 & 46 & 45 & 51 \\
\hline South Africa & 59 & 59 & 59 & 54 & 53 & 50 & 52 & 54 & 52 \\
\hline Bolivia (Plurinational State of) & 46 & 48 & 50 & 52 & 51 & 51 & 53 & 51 & 53 \\
\hline El Salvador & 48 & 50 & 51 & 53 & 52 & 53 & 55 & 53 & 54 \\
\hline Sudan & 126 & 124 & 123 & 124 & 101 & 105 & 100 & 94 & 55 \\
\hline Malawi & 68 & 67 & 54 & 46 & 50 & 56 & 49 & 58 & 56 \\
\hline Paraguay & 50 & 52 & 52 & 56 & 54 & 57 & 56 & 56 & 57 \\
\hline Dominican Republic & 51 & 51 & 53 & 55 & 55 & 58 & 57 & 57 & 58 \\
\hline Ukraine & 58 & 60 & 63 & 65 & 62 & 55 & 54 & 55 & 59 \\
\hline Costa Rica & 52 & 53 & 56 & 59 & 57 & 59 & 58 & 59 & 60 \\
\hline Hungary & 53 & 55 & 55 & 58 & 60 & 60 & 59 & 60 & 61 \\
\hline Rwanda & 55 & 54 & 57 & 57 & 59 & 61 & 61 & 63 & 62 \\
\hline Nicaragua & 54 & 56 & 58 & 60 & 61 & 62 & 63 & 64 & 63 \\
\hline Peru & 56 & 57 & 60 & 61 & 63 & 63 & 62 & 61 & 64 \\
\hline Cote d'Ivoire & 123 & 114 & 73 & 76 & 79 & 84 & 84 & 62 & 65 \\
\hline Central African Republic & 70 & 68 & 68 & 51 & 58 & 54 & 60 & 68 & 66 \\
\hline Uganda & 66 & 63 & 64 & 63 & 65 & 66 & 65 & 67 & 67 \\
\hline Nigeria & 73 & 73 & 76 & 78 & 78 & 77 & 70 & 66 & 68 \\
\hline Tunisia & 61 & 61 & 65 & 66 & 66 & 65 & 66 & 65 & 69 \\
\hline Mozambique & 67 & 71 & 75 & 73 & 76 & 75 & 64 & 70 & 70 \\
\hline Belarus & 63 & 64 & 67 & 68 & 69 & 67 & 67 & 69 & 71 \\
\hline United Republic of Tanzania & 60 & 58 & 61 & 64 & 64 & 64 & 68 & 72 & 72 \\
\hline Ecuador & 62 & 62 & 66 & 67 & 67 & 68 & 69 & 71 & 73 \\
\hline Algeria & 74 & 75 & 77 & 77 & 77 & 74 & 73 & 74 & 74 \\
\hline Trinidad and Tobago & 64 & 65 & 69 & 70 & 71 & 70 & 71 & 73 & 75 \\
\hline Cyprus & 65 & 66 & 70 & 71 & 70 & 69 & 72 & 75 & 76 \\
\hline Pakistan & 71 & 70 & 72 & 69 & 72 & 76 & 77 & 78 & 77 \\
\hline Cameroon & 69 & 69 & 71 & 72 & 74 & 71 & 76 & 76 & 78 \\
\hline Zambia & 72 & 72 & 74 & 75 & 75 & 72 & 74 & 77 & 79 \\
\hline Ethiopia & 98 & 89 & 62 & 62 & 68 & 78 & 80 & 83 & 80 \\
\hline Morocco & 97 & 76 & 82 & 82 & 82 & 82 & 81 & 80 & 81 \\
\hline Burkina Faso & 75 & 77 & 80 & 80 & 81 & 79 & 78 & 81 & 82 \\
\hline Kuwait & 79 & 81 & 85 & 88 & 87 & 87 & 86 & 82 & 83 \\
\hline Cuba & 128 & 129 & 132 & 83 & 85 & 86 & 87 & 85 & 84 \\
\hline
\end{tabular}


Table 13 (continued)

\begin{tabular}{|c|c|c|c|c|c|c|c|c|c|}
\hline Country & 2010 & 2011 & 2012 & 2013 & 2014 & 2015 & 2016 & 2017 & 2018 \\
\hline Saudi Arabia & 82 & 83 & 87 & 84 & 86 & 85 & 83 & 84 & 85 \\
\hline Mali & 77 & 78 & 81 & 81 & 83 & 81 & 85 & 88 & 86 \\
\hline Suriname & 81 & 80 & 84 & 89 & 90 & 89 & 88 & 86 & 87 \\
\hline Burundi & 145 & 141 & 79 & 74 & 84 & 101 & 98 & 102 & 88 \\
\hline Bulgaria & 78 & 79 & 83 & 86 & 88 & 88 & 89 & 87 & 89 \\
\hline Uruguay & 80 & 82 & 86 & 90 & 92 & 90 & 90 & 90 & 90 \\
\hline Guinea & 76 & 74 & 78 & 79 & 80 & 83 & 82 & 89 & 91 \\
\hline Bahrain & 83 & 84 & 90 & 93 & 94 & 92 & 91 & 91 & 92 \\
\hline Jordan & 84 & 85 & 89 & 92 & 93 & 93 & 92 & 92 & 93 \\
\hline Colombia & 95 & 101 & 103 & 104 & 104 & 96 & 93 & 93 & 94 \\
\hline Timor-Leste & 85 & 86 & 88 & 95 & 96 & 99 & 102 & 99 & 95 \\
\hline Benin & 90 & 91 & 94 & 97 & 99 & 94 & 94 & 95 & 96 \\
\hline Kyrgyzstan & 86 & 90 & 96 & 98 & 98 & 95 & 97 & 96 & 97 \\
\hline Myanmar & 88 & 92 & 95 & 94 & 97 & 98 & 99 & 98 & 98 \\
\hline Czechia & 138 & 142 & 142 & 99 & 91 & 91 & 95 & 97 & 99 \\
\hline Malaysia & 100 & 103 & 102 & 101 & 102 & 102 & 101 & 100 & 100 \\
\hline Kenya & 87 & 87 & 93 & 96 & 100 & 100 & 103 & 103 & 101 \\
\hline Sao Tome and Principe & 91 & 94 & 97 & 100 & 103 & 104 & 104 & 104 & 102 \\
\hline Libya & 105 & 97 & 109 & 107 & 106 & 97 & 96 & 101 & 103 \\
\hline Yemen & 125 & 121 & 121 & 126 & 131 & 126 & 111 & 105 & 104 \\
\hline Lao People's Democratic Republic & 92 & 95 & 101 & 103 & 105 & 107 & 107 & 107 & 105 \\
\hline Romania & 110 & 110 & 111 & 115 & 117 & 110 & 108 & 106 & 106 \\
\hline Niger & 109 & 104 & 104 & 102 & 107 & 103 & 105 & 109 & 107 \\
\hline Slovakia & 93 & 100 & 100 & 105 & 108 & 106 & 106 & 108 & 108 \\
\hline Djibouti & 99 & 98 & 99 & 106 & 109 & 108 & 109 & 110 & 109 \\
\hline Angola & 151 & 154 & 154 & 148 & 120 & 118 & 116 & 118 & 110 \\
\hline Cabo Verde & 108 & 108 & 108 & 110 & 112 & 111 & 112 & 112 & 111 \\
\hline Iraq & 114 & 116 & 119 & 122 & 124 & 117 & 113 & 111 & 112 \\
\hline Azerbaijan & 117 & 118 & 120 & 123 & 125 & 122 & 114 & 114 & 113 \\
\hline Mongolia & 104 & 109 & 113 & 113 & 115 & 114 & 118 & 115 & 114 \\
\hline Eswatini & 152 & 153 & 114 & 112 & 114 & 113 & 115 & 117 & 115 \\
\hline Armenia & 107 & 107 & 110 & 111 & 113 & 112 & 117 & 116 & 116 \\
\hline Republic of Moldova & 103 & 105 & 106 & 109 & 110 & 109 & 110 & 113 & 117 \\
\hline Albania & 111 & 111 & 112 & 114 & 116 & 115 & 119 & 119 & 118 \\
\hline Croatia & 118 & 119 & 122 & 125 & 126 & 125 & 125 & 120 & 119 \\
\hline Ireland & 106 & 106 & 107 & 108 & 111 & 116 & 120 & 121 & 120 \\
\hline Namibia & 115 & 115 & 117 & 119 & 121 & 121 & 121 & 122 & 121 \\
\hline Republic of North Macedonia & 112 & 112 & 115 & 118 & 122 & 120 & 124 & 125 & 122 \\
\hline Bosnia and Herzegovina & 113 & 113 & 116 & 117 & 119 & 119 & 122 & 124 & 123 \\
\hline Serbia & 116 & 117 & 118 & 121 & 123 & 123 & 123 & 123 & 124 \\
\hline Lithuania & 121 & 123 & 126 & 129 & 130 & 128 & 127 & 126 & 125 \\
\hline Latvia & 120 & 122 & 125 & 128 & 128 & 127 & 128 & 127 & 126 \\
\hline
\end{tabular}


Table 13 (continued)

\begin{tabular}{|c|c|c|c|c|c|c|c|c|c|}
\hline Country & 2010 & 2011 & 2012 & 2013 & 2014 & 2015 & 2016 & 2017 & 2018 \\
\hline Seychelles & 119 & 120 & 124 & 127 & 127 & 129 & 129 & 128 & 127 \\
\hline Barbados & 165 & 164 & 167 & 167 & 129 & 130 & 130 & 129 & 128 \\
\hline Thailand & 139 & 139 & 143 & 116 & 118 & 124 & 126 & 131 & 129 \\
\hline Malta & 122 & 125 & 127 & 130 & 132 & 131 & 131 & 130 & 130 \\
\hline Monaco & 124 & 126 & 128 & 131 & 133 & 132 & 132 & 132 & 131 \\
\hline Zimbabwe & 131 & 132 & 136 & 133 & 135 & 133 & 133 & 133 & 132 \\
\hline Lebanon & 129 & 130 & 133 & 136 & 138 & 136 & 136 & 134 & 133 \\
\hline Viet Nam & 146 & 146 & 131 & 135 & 137 & 135 & 135 & 135 & 134 \\
\hline Brunei Darussalam & 130 & 131 & 134 & 137 & 139 & 138 & 137 & 137 & 135 \\
\hline Nepal & 136 & 127 & 129 & 132 & 134 & 134 & 134 & 136 & 136 \\
\hline United Arab Emirates & 132 & 133 & 135 & 138 & 142 & 139 & 139 & 138 & 137 \\
\hline Cambodia & 127 & 128 & 130 & 134 & 136 & 137 & 138 & 139 & 138 \\
\hline Sri Lanka & 140 & 143 & 145 & 145 & 146 & 141 & 140 & 140 & 139 \\
\hline Mauritania & 133 & 134 & 137 & 140 & 141 & 140 & 141 & 141 & 140 \\
\hline Singapore & 143 & 145 & 147 & 147 & 149 & 142 & 142 & 142 & 141 \\
\hline Comoros & 135 & 135 & 138 & 141 & 143 & 143 & 143 & 143 & 142 \\
\hline Qatar & 134 & 136 & 139 & 142 & 144 & 145 & 144 & 144 & 143 \\
\hline Gambia & 144 & 138 & 140 & 139 & 140 & 144 & 145 & 145 & 144 \\
\hline Tajikistan & 141 & 140 & 144 & 144 & 148 & 147 & 146 & 147 & 145 \\
\hline Guyana & 137 & 137 & 141 & 143 & 145 & 146 & 147 & 146 & 146 \\
\hline Bahamas & 142 & 144 & 146 & 146 & 147 & 148 & 148 & 148 & 147 \\
\hline Chad & 168 & 169 & 163 & 155 & 165 & 152 & 150 & 149 & 148 \\
\hline Papua New Guinea & 147 & 148 & 151 & 152 & 152 & 150 & 151 & 150 & 149 \\
\hline Guinea-Bissau & 148 & 150 & 148 & 149 & 150 & 149 & 149 & 152 & 150 \\
\hline Bhutan & 149 & 149 & 150 & 151 & 151 & 151 & 152 & 151 & 151 \\
\hline Kazakhstan & 161 & 162 & 164 & 166 & 166 & 162 & 153 & 153 & 152 \\
\hline Georgia & 150 & 151 & 152 & 154 & 155 & 153 & 154 & 154 & 153 \\
\hline Belize & 153 & 152 & 153 & 153 & 154 & 154 & 155 & 155 & 154 \\
\hline Oman & 159 & 160 & 161 & 163 & 163 & 156 & 156 & 156 & 155 \\
\hline Fiji & 179 & 182 & 182 & 185 & 185 & 184 & 183 & 157 & 156 \\
\hline Turkmenistan & 154 & 155 & 157 & 160 & 160 & 157 & 157 & 158 & 157 \\
\hline Saint Vincent and the Grenadines & 155 & 156 & 155 & 156 & 156 & 160 & 159 & 159 & 158 \\
\hline Dominica & 181 & 184 & 184 & 157 & 157 & 164 & 163 & 160 & 159 \\
\hline Botswana & 156 & 159 & 158 & 159 & 159 & 159 & 161 & 163 & 160 \\
\hline Slovenia & 160 & 161 & 160 & 162 & 161 & 163 & 160 & 161 & 161 \\
\hline Montenegro & 157 & 158 & 156 & 158 & 158 & 158 & 158 & 162 & 162 \\
\hline Nauru & 180 & 183 & 162 & 164 & 164 & 161 & 162 & 164 & 163 \\
\hline Maldives & 174 & 175 & 175 & 173 & 172 & 171 & 164 & 165 & 164 \\
\hline Grenada & 158 & 157 & 159 & 161 & 162 & 165 & 165 & 166 & 165 \\
\hline Antigua and Barbuda & 162 & 163 & 165 & 165 & 167 & 166 & 167 & 167 & 166 \\
\hline Saint Kitts and Nevis & 164 & 165 & 166 & 168 & 168 & 168 & 169 & 169 & 167 \\
\hline Estonia & 163 & 166 & 168 & 169 & 169 & 167 & 168 & 168 & 168 \\
\hline
\end{tabular}


Table 13 (continued)

\begin{tabular}{|c|c|c|c|c|c|c|c|c|c|}
\hline Country & 2010 & 2011 & 2012 & 2013 & 2014 & 2015 & 2016 & 2017 & 2018 \\
\hline San Marino & 166 & 167 & 169 & 170 & 170 & 169 & 170 & 170 & 169 \\
\hline Bangladesh & 169 & 147 & 149 & 150 & 153 & 155 & 166 & 172 & 170 \\
\hline Kiribati & 167 & 168 & 170 & 171 & 171 & 170 & 171 & 171 & 171 \\
\hline Uzbekistan & 170 & 170 & 171 & 172 & 173 & 172 & 172 & 173 & 172 \\
\hline Equatorial Guinea & 173 & 173 & 173 & 176 & 176 & 174 & 173 & 174 & 173 \\
\hline Saint Lucia & 182 & 185 & 185 & 174 & 174 & 173 & 174 & 175 & 174 \\
\hline Iceland & 172 & 171 & 172 & 175 & 175 & 175 & 175 & 176 & 175 \\
\hline Micronesia (Federated States of) & 175 & 174 & 174 & 177 & 177 & 176 & 176 & 177 & 176 \\
\hline Marshall Islands & 177 & 176 & 176 & 178 & 178 & 177 & 177 & 178 & 177 \\
\hline Samoa & 184 & 180 & 181 & 183 & 179 & 178 & 179 & 180 & 178 \\
\hline Tonga & 178 & 181 & 183 & 184 & 180 & 179 & 178 & 179 & 179 \\
\hline Andorra & 183 & 177 & 178 & 179 & 182 & 181 & 180 & 181 & 180 \\
\hline Vanuatu & 175 & 178 & 179 & 180 & 183 & 182 & 181 & 182 & 181 \\
\hline Congo & 176 & 179 & 180 & 182 & 184 & 183 & 182 & 183 & 182 \\
\hline Tuvalu & 184 & 186 & 186 & 186 & 186 & 185 & 184 & 184 & 183 \\
\hline Palau & 184 & 186 & 186 & 186 & 186 & 185 & 184 & 184 & 183 \\
\hline Solomon Islands & 184 & 186 & 186 & 186 & 186 & 185 & 184 & 184 & 183 \\
\hline Iran (Islamic Republic of) & 94 & 96 & 98 & 91 & 89 & 80 & 79 & 79 & NA \\
\hline Venezuela (Bolivarian Republic of) & 47 & 47 & 49 & 49 & 49 & NA & NA & NA & NA \\
\hline Eritrea & 171 & 172 & NA & NA & NA & NA & NA & NA & NA \\
\hline South Sudan & 184 & 186 & 177 & 181 & 181 & 180 & NA & NA & NA \\
\hline
\end{tabular}

Traffic in Narcotic Drugs and Psychotropic Substances of 1988), the treaty against corruption (United Nations Convention against Corruption) and the treaty against taking of hostages (the International Convention Against the Taking of Hostages).

These treaties request nation states to take a series of measures to cooperatively combat transnational organized crimes, including information sharing, adopting legal frameworks in favor of law enforcement cooperation, and police force and expert training plans. It also provides legal and technical assistance to help nation states to build and upgrade the necessary capacity. ${ }^{47}$ For example, in regard to money laundering, the UN Convention against Transnational Organized Crime stipulates that each state "shall institute a comprehensive domestic regulatory and supervisory regime for banks and non-bank financial institutions and, where appropriate, other bodies particularly susceptible to money-laundering, within its competence, in order to deter and detect all forms of money-laundering, which regime shall emphasize requirements for customer identification, record-keeping and the reporting of suspicious transactions". ${ }^{48}$ As a result, ratification of the treaties denotes compliance

\footnotetext{
47 https://www.unodc.org/unodc/en/organized-crime/intro/UNTOC.html.

48 United Nations Convention against Transnational Organized Crime and the Protocols Thereto (2004), United Nations, p.9.
} 
with the related requirements and the promise to offer relevant assistance. Moreover, the ratification status of each country also shows their contribution to cross-national cooperation on crime.

For the category of contribution, we measure donations to Interpol donations to UNODC and FATF membership. First, as we discussed in our report last year, since the combatting of transnational crime relies on the actions of more than one country, it is necessary to have an international organization with a well-established communication system to connect all countries, which is what Interpol does. Interpol is the biggest organization in the world t providing technical and operational support in the fight against transnational crime. ${ }^{49}$ As a result, financial donations to Interpol reflect the determination and contribution of a country to transnational cooperation on crime. Secondly, we include donations to UNODC this year. UNODC is also an important organization in the international cooperation against organized crime. It organizes seminars, conferences and working groups under the Organized Crime Convention, which brings together specialists and scholars with relevant expertise and experience to promote the implementation of the Convention. It also provides technical assistance and a platform for cooperation to strengthen governments' capabilities in combating organizational crimes. ${ }^{50}$ In this sense, financial donations to UNODC facilitate transnational cooperation on crime. Third, we include FATF membership in our measurement, which plays a major role in the global effort to tackle money laundering.

Please see below the details of all the indicators in our measurement of global cooperation against transnational crime.

As shown in Table 10, due to data limitations, we obtained the data for 2018 for the indicators of donations to UNODC and FATF membership; for the rest of the indicators, we obtained the data from 2010 to 2018 (Table 11). As a result, we generate two versions of the rankings for this issue. In the first version (see Table 12), we include all of the indicators to provide a more precise result of each countries' performance and contribution to police cooperation against transnational crime. However, due to the inconsistency in the indicators' year coverage, there is an obvious variation between the results of 2017 and 2018. As a result, we provide a complementary second version. In the second version (see Table 13), we remove these two indicators (donation to UNODC and FATF membership) to ensure year coverage consistence. This version of the ranking provides a more accurate account of trends in each countries' ranking over time.

\subsubsection{Results}

According to the results, the Unites States performs excellently in both performance and contribution in police cooperation against transnational crime. It has maintained first place from 2010 to 2018. European countries such as Germany, Britain and Italy also perform well. Japan and China achieve high ranking in Asia. Countries

\footnotetext{
49 Please check https://www.interpol.int/en for more information about Interpol.

50 https://www.unodc.org/unodc/en/organized-crime/technical-assistance.html
} 


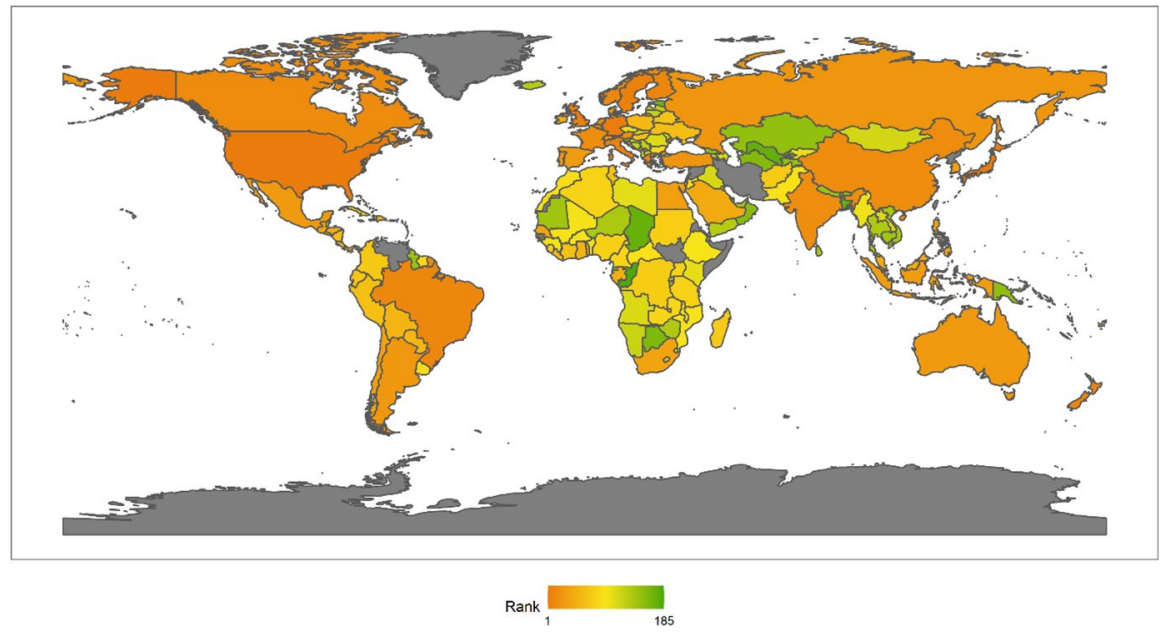

Fig. 92018 Index ranking of police cooperation against transnational crime on a world map

in Latin America with a serious transnational crime problem, such as Brazil, also perform well.

The United States has a long history in combating transnational crime. From America's first-ever International Crime Control Strategy, announced by the President Clinton in 1998, to the 2011 Strategy to Combat Transnational Organized Crime and the 2017 Presidential Executive Order on Enforcing Federal Law with Respect to Transnational Criminal Organizations and Preventing International Trafficking, the US government has initiated various policies and programs to combat transnational crimes and ensure national security. Some of these policies are designed to investigate, disrupt and dismantle transnational criminal networks, and others facilitate bilateral and multilateral law enforcement cooperation with international organizations and government institutions. Against this backdrop, the Trump administration also intensified previous efforts by "exercising and expanding prosecutions, sanctions and enforcement agencies' legal authorities; allocating additional investigative resources; and demonstrating the political will to bring TCOs to justice, seize their assets and deny them access to the international financial system." 51 Congress is the main institution that formulates and directs strategies and policies regarding transnational crime. Federal agencies including the Departments of Defense, Justice and Homeland Security are responsible for the implementation of these policies, including criminal investigations, coordination, etc.

\footnotetext{
51 AEI WORKING GROUP ON TRANSNATIONAL ORGANIZED CRIME IN THE AMERICAS. (2017). Kingpins and Corruption: TARGETING TRANSNATIONAL ORGANIZED CRIME IN THE AMERICAS (pp. 5-10, Rep.). American Enterprise Institute. Retrieved January 30, 2021, from http:// www.jstor.org/stable/resrep03288.4.
} 


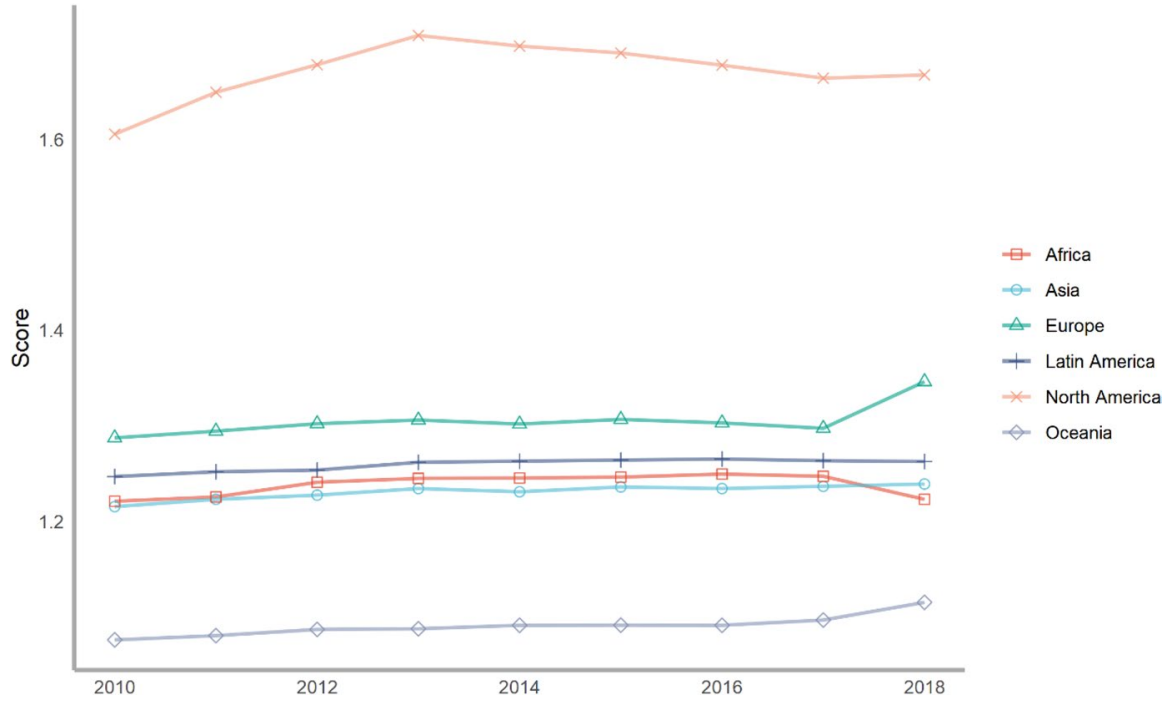

Fig. 10 Scores for police cooperation against transnational crimes across continents, 2010-2018

European countries also have relatively long histories in combating transnational crime. Alongside the collapse of the Soviet Union and the subsequent changes in Russia and the Commonwealth of Independent States, the phenomenon of transnational organized crime has moved from the Eastern Europe to Western Europe and became an apparent threat to many democratic Western countries. ${ }^{52}$ The existence of the EU provides a platform for facilitating bilateral and multilateral cooperation among member states. Regarding legislation, it is possible for the EU to issue continental level legislation such as "Europol Convention", which aims to improve the "effectiveness and cooperation of the competent authorities in the Member States in preventing and combating terrorism, unlawful drug trafficking and other serious forms of international crime" ${ }^{53}$ Furthermore, the European Police College provides policing officials training and assistance, while the Organization for Security and Co-operation in Europe strengthens policing-related capacity of member nations (Fig. 9).

The top 10 countries in 2018 (according to the first version of the index) were the Unites States, Japan, Germany, Great Britain, Sweden, Belgium, Italy, Greece, Finland and New Zealand. These countries performed well in both performance and contribution. The above map shows the ranking of each country in 2018. Compared with the results for 2017 in our last annual report, little has changed. Countries in North America, South America, Europe and Australia made relatively greater contributions compared with nations in Africa and Southeast Asia. In Africa, Algeria, Libya and South Africa contributed relatively more than did the other countries.

\footnotetext{
52 Foertsch. (1999).

53 Europol Convention. P. 6.
} 


\subsubsection{Regional Analysis}

See Fig. 10.

Asia Within Asia, Southeast Asia is the region with highly developed transnational organized crime. One reason for this is that border management is relatively weak and cross-border corruption is a serious problem. The four most active transnational organized crime markets in the Southeast Asian region are: drugs and precursor chemicals (methamphetamine and heroin, trafficking in persons and smuggling of migrants, environmental crimes (wildlife and timber trafficking), and counterfeit goods and falsified medicines. ${ }^{54}$ Meanwhile, criminal activities and networks in Southeast Asia have achieved global reach and affected surrounding regions. As a result, regional cooperation is crucial in combating transnational organized crime in Asia, and the Association of Southeast Asia (ASEAN) plays a very important role. ASEAN was established on 8 August 1967 in Bangkok, Thailand. The initial member states included Thailand, Indonesia, Malaysia, Philippines and Singapore. The main purposes of ASEAN are to accelerate economic growth, promote regional peace and active collaboration and provide mutual assistance. Combating transnational crime has been one of its major aims since 1976, but the focus from 1976 to 1997 was limited to the illegal drug trafficking, which led to it having only a weak impact. On 20 December 1997, ASEAN issued the ASEAN Declaration on Transnational Crime, which was the beginning of a series of cooperative activities between governments. After that, combatting money laundering and counter-terrorism were included in the ASEAN agenda against transnational organized crime. ${ }^{55}$

ASEAN has also been in cooperation with countries in other parts of Asia. For example, Japan is a long standing partner of ASEAN. In 2004, ASEAN and Japan issued the ASEAN-Japan Joint Declaration for Cooperation to Combat International Terrorism, and in 2014 they put forward the ASEAN-Japan Joint Declaration for Cooperation to Combat Terrorism and Transnational Crime. Both of the declarations emphasize the importance of strengthening cooperation at bilateral, regional and international levels to combat transnational crime through information exchange and intelligence sharing. Japan has the highest score in Asia in our ranking. Other East Asian countries also performed relatively well and ranked highly under our measurement, including China and Korea. In China, a particular problem relating to organized crime corruption. The Chinese government has facilitated many bilateral and multilateral cooperative efforts with other countries to combat transnational crime, especially corruption, money laundering and drug smuggling and ensure national security. In contrast to many other countries, such as EU member states, informal cooperation is the most prominent type of cooperation in combating transnational crimes in China. ${ }^{56}$

\footnotetext{
54 United Nations Office on Drugs and Crime (2019), Transnational Organized Crime in Southeast Asia: Evolution, Growth and Impact.

55 Ralf Emmers (2003).

56 Saskia Hufnagel (2014).
} 
However, there exists research showing that, compared with other regions, the major problem in Asia is that consensus is limited among Asian authorities on what the main organized crime-related problems are. Different Asian countries have different opinions about which specific type of organized crimes should be regarded as the most important. Transnational crime may not be a priority to all of them. "Consistent with this view, Asian authorities do not see much linkage between the local or regional criminal groups about which they are most concerned and transnational organized crime. There is limited collaboration or linkage between transnational organized crime groups and terrorists." 57 As a result, reinforcing cooperation and establishing operating networks is still a method through which Asian authorities could improve their capability and efficienscy in combating transnational crimes.

Europe The existence of the EU provides a platform for bilateral and multilateral cooperation among member states, which partially explains why European countries performed generally well on this issue. There are a large number of programs, plans and associations regarding combating transnational crimes among EU member states. For example, the Central European Initiative (CEI), the Organization for Security and Cooperation in Europe (OSCE), the European Commission, the European Union Council and its secretariat, the Council of Europe, Europol, the Southeast European Cooperation Initiative (SECI), the Stability Pact and the Adriatic Sea Initiative, Southeast European Law Enforcement Center (SECI) for the Fight against Organized Crime in Bucharest and the Stability Pact initiative on Organized Crime (SPOC). ${ }^{58}$

Compared with Western Europe, the problem of transnational crime is more serious in Southeastern Europe. Transnational organized crime and corruption have been identified by the EU as key problems in Southeastern Europe and obstacles to European integration. ${ }^{59}$ Multiple policies have been issued to attempt to solve the problem. Taking the corruption in customs agencies as an example, states in Southeastern Europe, including Estonia, Hungary, Latvia, Lithuania, Slovenia, Poland, Romania and Bulgaria, have introduced various regulations to establish control mechanisms and improve transparency. More specifically, "Hungary set up a Central Investigation Office in 2000. Latvia introduced the following customs measures: a system of electronic declaration of goods, a more precise delineation of duties and authorities of customs officers, a cooperation scheme with the Border Guard, and staff rotation. Customs departments in Lithuania and Slovenia also undertook a series of reforms." $" 60$

North America Both the US and Canada performed well in combating transnational organized crimes. According to our ranking, the US maintained first place from 2010 to 2018 on this issue, and Canada also ranked 14th in 2018. Organized crime in North America is not singular phenomenon. In most cases, it is perpetrated by large and small groups which cooperate to make a given crime possible. There

\footnotetext{
57 Finckenauer \& Chin (2006).

58 Woodward, Susan L(2004).

59 Velkova \& Saso (2004).

60 Velkova \& Saso (2004)
} 
are five major categories of transnational criminals that have been most widely discussed: Cosa Nostra groups, Russian groups, Chinese groups, Mexican groups, and Canadian groups. ${ }^{61}$ As discussed above, in respect to nationwide transnational crimes, there have been a large number of policies, programs and initiatives between North American countries and Latin American countries to facilitate cooperative combating of transnational organized crime. Taking cooperation between the US and Mexico as an example, Amy Pope summarized three reasons why successful cooperation has taken place. She compared two human trafficking cases which were successfully investigated and prosecuted in both the US and Mexico. According to her research, the first important factor is commitment from key actors. In the two cases, senior leadership within the Mexican attorney general's office greatly supported the investigation and regarded it as a priority, which lead to the Mexican prosecutors participating at the working level. Second, mentoring and training is needed. Likewise, in these two cases the US provided training and assistance on law enforcement and other capacities. Third, it is crucial for the two countries to efficiently share formal and informal information and evidence. ${ }^{62}$

Latin America Among the various types of organized crimes, the problem of illegal drugs is the most serious transnational crime in Latin America. It is complex and dynamic, and response measures have changed over the years. Additionally, the problem of illegal drugs in Latin America has achieved global reach and played a crucial role in global illicit drug markets. For example, "South America is the sole producer of cocaine for the global market; Mexico and Colombia are the primary sources of opiates in the United States; Mexico and the Caribbean are major foreign sources of cannabis (marijuana) consumed in the United States; and Mexico is the primary source of foreign methamphetamine in the United States." ${ }^{23}$ As a result, North American countries and as EU countries have worked closely with Mexico, Colombia, and the Caribbean through information exchange and intelligence sharing to establish cooperative frameworks to combat drug trafficking. For example, the US Congress first enacted a chapter in the Foreign Assistance Act in 1971 that mentioned drug control programs in Latin America and the Caribbean. In the mid1970s, the US has begun to provide training and equipment assistance to drug source countries of Colombia, Bolivia, Peru and Later Mexico to improve counternarcotic law enforcement capabilities. ${ }^{64}$ The Plan Colombia and Plan Mexico (The Merida Initiative in Mexico) are also examples of US efforts to improve the professionalism of police forces and judicial system capacity by providing financial and personnel assistance. The former, which is a security cooperation agreement between the United States, Mexico and other countries in Central America, builds on the experience of the latter, which aimed at combating Colombian drug trafficking. The flourishing of such institutions, programs and plans are not only in the interests of Latin America, but also contribute to the improvement of global justice. Besides direct

\footnotetext{
61 Finckenauer \& Albanese (2014).

62 Amy Pope (2013), 'Partnering with Mexico to Fight Transnational Crime', GPSolo 30(5):66-67.

63 Seelke (2010).

64 Seelke. (2010).
} 
assistance through policy tools, another way for the US and EU countries to better assist Latin America in combating drug trafficking is by "expanding efforts to prevent, treat, and reduce the harm associated with drug use, while also reprioritizing enforcement efforts." 65

Africa Countries in Africa stood at the bottom according to our ranking on combating transnational crime. Research by Hatchard analyzed three challenges faced by Africa in combating transnational crime and discussed how African countries can address these challenges. The first challenge is "how to deal with crimes that emanate from outside the jurisdiction". The second challenge concerns "investigating crimes with a transnational element". And the third challenge is "tracing and then recovering the proceeds of crime that have been moved out of the country where the crime occurred". ${ }^{66}$ According to Hatchad, one way to cope with these challenges is by prosecuting the perpetrators. In addition, African countries can take advantage of Interpol, which counts all sub-Saharan African states as members, since "it facilitates cross-border police cooperation, even where diplomatic relations do not exist between the requested and requesting countries". Finally, there are three other points that are worth taking notice of. First, the need for political will to tackle transnational crime is fundamental. Second, the investigation and prosecution of such cases is often an expensive business and it is entirely justifiable that African states look to other countries to assist with this heavy financial burden. Third, the issue of immunities remains an obstacle to the prosecuting of serving heads of state/government suspected of involvement in transnational criminal activities.

Oceania Oceanian countries have a relatively low level of crime prevalence. However, given the pace of globalization, Oceanian countries have also been influenced by global criminal networks and foreign criminal groups, and transnational crime has become increasingly common. The most significant category of transnational organized crime in the Oceanian region is the illicit drug industry. Indeed, Oceania has the highest rate of use of amphetamine-type stimulants and cannabis in the world. ${ }^{67}$ As a result, it is also important for Oceanian countries to participate into the global network against transnational crime in order to obtain access to information and intelligence. There have been bilateral legal and cooperative initiatives between Australia and regional states, such as China, Malaysia, Thailand, Vietnam and Indonesia. The cooperation can improve the capacity of Australia to prevent and combat criminal activities and ensure the safety and security of the state.

\subsubsection{Conclusion}

Transnational organized crime threatens the interests, stability and national security of every state, which makes combating transnational crime an important part of improving global justice. In this section, we measure the performance and contribution of each nation state in combating transnational crime with 14 indicators

\footnotetext{
65 José María et al. (2013).

66 John Hatchard (2006).

67 Broadhurst et al. (2014).
} 
in all. Nine of the indicators relate to the ratification status of each country of relevant treaties, while the remainder of the indicators belong to the category of contribution, which measures donations to Interpol, donations to UNODC and FATF membership. According to our results, the Unites States has ranked at the top from 2010 to 2018. European countries also ranked highly according to our measurement. In Asia, Japan and China performed well. Generally speaking, countries in North America, South America, Europe and Australia made relatively greater contributions compared with nations in Africa and Southeast Asia.

\subsection{Issue 6: Refugees}

\subsubsection{Introduction}

The world has witnessed an unprecedented level of human mobility over decades. Millions of people around the world have moved to escape armed conflicts, terrorism, persecution, poverty, food insecurity, environmental disasters and other life challenges. These people are usually treated as "refugees". According to the UN refugee agency, refugees are "people who have fled war, violence, conflict or persecution and have crossed an international border to find safety in another country." 68

Today, the refugee crisis is one of the most complex issues in the world: it not only has a range of economic, social, political and environmental impacts on both the home and host countries, ${ }^{69}$ but has also posted great challenges to global justice. Therefore, we include refugee issue as one of the key issue areas in this year's global justice index, to improve the measurement of developments in global justice.

The most recent UN figures report that forcibly displaced people are estimated at 79.5 million worldwide by the end of 2019 , representing about $1 \%$ of the world's population. Of these, 45.7 million are internally displaced persons, and 25.9 million are refugees who have been forced to flee their countries, around half of whom are under the age of 18. Statistics from 2010 to 2018 further indicate that the volume of refugee movements across international borders has more than doubled and has reached a thirty-year high. ${ }^{70}$ During 2018 alone, 1.1 million people were recognized as new refugees. The refugee crisis is a global challenge that individual states cannot address alone. "Refugee crises call for a global sharing of responsibility," said Filippo Grandi, the head of the United Nations High Commissioner for Refugees (UNHCR). As of December 2019, 146 and 147 UN member states have, respectively, ratified the key international legal framework for the protection of refugees, the 1951 Convention relating to the Status of Refugees and its updating Protocol adopted in 1967. Today, as refugee numbers continue to grow, the need for more

\footnotetext{
68 See https://www.unhcr.org/what-is-a-refugee.html (accessed November 17, 2020). There are different approaches to conceptualize refugees, but a common sense is that refugees are not migrants. For details, see David Scott FitzGerald and Rawan Arar. 2018. "The Sociology of Refugee Migration", Annual Review of Sociology 44: 387-406.

69 Elena et al. (2014).

70 See https://www.unhcr.org/uk/figures-at-a-glance.html (accessed November 17, 2020).
} 
comprehensive, more coherent and more coordinated policies to manage refugee flows and protect the rights and well-being of forced migrants is greater than ever.

As a truly "whole-of-international community affair", the governance of the refugee problem needs to adopt the principle of "Common but Differentiated and Respective Capabilities (CBDR-RC)" proposed by our project. Achieving global justice by safeguarding the rights and well-being of refugees and their families ${ }^{71}$ not only requires cooperation and dialogue between and among countries, but also calls for actions and contributions by individual countries, ${ }^{72}$ including both countries of origin and countries of destination. Efforts by individual countries to combat the refugee crisis are a significant aspect of the global justice agenda. This sub-index is designed and constructed to rank individual countries according to their level of performance in and contribution to global justice in the field of refugee governance.

\subsubsection{Dimensions and Indicators}

The refugee issue is a multidimensional. It is highly challenging, if not impossible, to construct a sub-index to rank and compare individual states in managing the refugee crisis. As a first attempt, we try to use two categories, performance and contribution, to measure individual countries' influence on global justice in the issue area of refugee governance. For the category of performance, we use the size of the exported refugee population per 1000 inhabitants to measure a country's performance in reducing and governing refugees. For the category of contribution, we use five dimensions to measure each country's investments and efforts toward global refugee governance. These five dimensions are as follows: (1) the number of imported refugees divided by the natural logarithm of $\mathrm{GDP}^{73}$; (2) implementation of RSD (refugee status determination), measured by the number of decisions made and proportion of positive decisions made; (3) participation in international refugee governance measured by membership of UNHCR and the signing of international agreements, including the 1951 Convention relating to the Status of Refugees and its 1967 Protocol; (4) national policies on managing refugee issues, including indicators such as systems for receiving, processing and identifying refugees, planning for displaced populations, specific measures to provide assistance, disaster risk reduction strategies and granting of permission for temporary stay or temporary protection; (5) standard of living for refugees, measured by type of refugee accommodation provided. Data are obtained from the World Bank, UNHCR Statistical Yearbook, UNHCR-Annex of Global Appeal, and UN Report of World Population Policies respectively (see Table 14). Relying on these multidimensional data and the measurement strategies, we try to present a more comprehensive picture of global justice in the domain of refugee governance.

\footnotetext{
71 Mark Gibney (2010).

72 David Owen. (2018).

73 We assume that the capacity of a country in accommodating imported refugees are related to its economic conditions.
} 


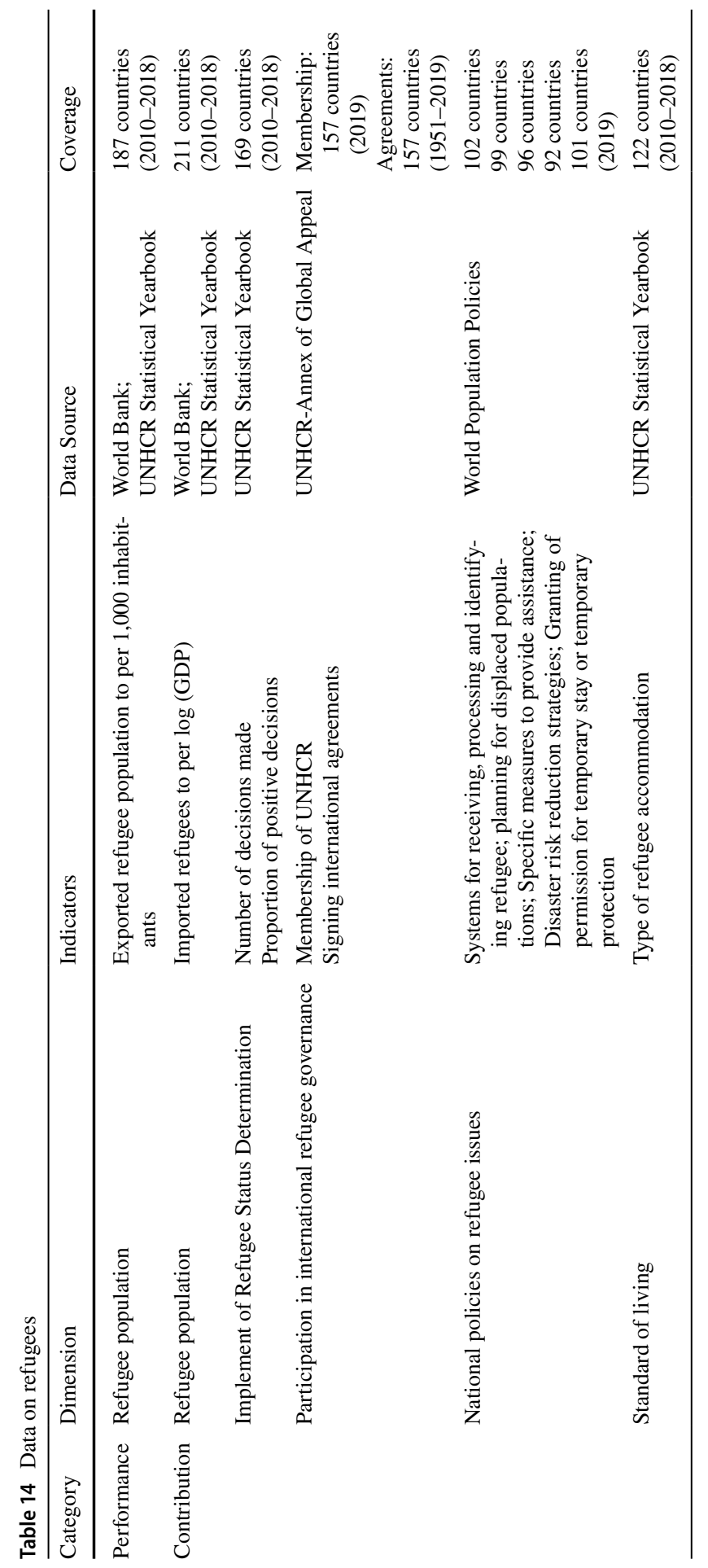


Table 15 Country ranking in refugee aspect of promoting global justice

\begin{tabular}{|c|c|c|c|c|c|c|c|c|c|}
\hline Country & 2010 & 2011 & 2012 & 2013 & 2014 & 2015 & 2016 & 2017 & 2018 \\
\hline Sweden & 3 & 2 & 1 & 1 & 1 & 1 & 1 & 3 & 1 \\
\hline France & 1 & 1 & 2 & 2 & 2 & 3 & 4 & 8 & 2 \\
\hline Germany & 9 & 8 & 8 & 8 & 11 & 5 & 3 & 7 & 3 \\
\hline Spain & 6 & 4 & 4 & 4 & 3 & 2 & 2 & 5 & 4 \\
\hline $\begin{array}{l}\text { United Kingdom of Great Britain and } \\
\text { Northern Ireland }\end{array}$ & 2 & 3 & 3 & 3 & 4 & 4 & 5 & 9 & 5 \\
\hline Switzerland & 8 & 9 & 11 & 10 & 8 & 9 & 7 & 4 & 6 \\
\hline Finland & 7 & 7 & 5 & 5 & 5 & 7 & 6 & 2 & 7 \\
\hline Canada & 5 & 6 & 7 & 6 & 6 & 6 & 9 & 11 & 8 \\
\hline Ireland & 10 & 10 & 10 & 11 & 12 & 12 & 13 & 6 & 9 \\
\hline Belgium & 25 & 17 & 18 & 17 & 18 & 14 & 12 & 12 & 10 \\
\hline Norway & 4 & 5 & 6 & 9 & 9 & 8 & 8 & 1 & 11 \\
\hline Denmark & 12 & 14 & 13 & 15 & 15 & 11 & 10 & 14 & 12 \\
\hline Argentina & 19 & 19 & 15 & 18 & 17 & 15 & 17 & 17 & 13 \\
\hline Italy & 11 & 11 & 9 & 7 & 7 & 10 & 14 & 15 & 14 \\
\hline Philippines & 20 & 20 & 16 & 16 & 14 & 16 & 18 & 18 & 15 \\
\hline Mozambique & 14 & 21 & 21 & 12 & 16 & 17 & 19 & 19 & 16 \\
\hline Brazil & 32 & 13 & 12 & 13 & 10 & 19 & 15 & 16 & 17 \\
\hline Austria & 13 & 12 & 14 & 14 & 13 & 13 & 16 & 10 & 18 \\
\hline Zambia & 16 & 24 & 17 & 21 & 20 & 20 & 22 & 22 & 19 \\
\hline Greece & 22 & 16 & 20 & 23 & 22 & 21 & 23 & 26 & 20 \\
\hline Portugal & 34 & 32 & 25 & 28 & 24 & 25 & 26 & 23 & 21 \\
\hline Japan & 43 & 38 & 29 & 20 & 21 & 22 & 21 & 29 & 22 \\
\hline Uruguay & 45 & 41 & 40 & 33 & 32 & 29 & 24 & 24 & 23 \\
\hline Thailand & 24 & 31 & 24 & 19 & 19 & 23 & 20 & 28 & 24 \\
\hline Australia & 27 & 23 & 23 & 22 & 23 & 24 & 27 & 27 & 25 \\
\hline United States of America & 28 & 26 & 35 & 35 & 41 & 43 & 30 & 33 & 26 \\
\hline Paraguay & 38 & 40 & 37 & 44 & 25 & 27 & 31 & 32 & 27 \\
\hline Malta & 31 & 36 & 38 & 29 & 39 & 18 & 11 & 13 & 28 \\
\hline Luxembourg & 15 & 18 & 19 & 27 & 31 & 33 & 33 & 20 & 29 \\
\hline Samoa & 29 & 27 & 26 & 30 & 27 & 30 & 32 & 21 & 30 \\
\hline Netherlands & 23 & 22 & 27 & 25 & 26 & 26 & 28 & 30 & 31 \\
\hline Lesotho & 37 & 37 & 31 & 36 & 36 & 49 & 34 & 31 & 32 \\
\hline United Republic of Tanzania & 21 & 35 & 33 & 24 & 30 & 28 & 25 & 25 & 33 \\
\hline Republic of Korea & 35 & 42 & 42 & 45 & 34 & 38 & 38 & 42 & 34 \\
\hline Malawi & 26 & 34 & 36 & 38 & 35 & 31 & 40 & 43 & 35 \\
\hline New Zealand & 30 & 28 & 28 & 31 & 28 & 32 & 35 & 40 & 36 \\
\hline Lithuania & 64 & 73 & 74 & 50 & 46 & 45 & 37 & 35 & 37 \\
\hline South Africa & 18 & 25 & 22 & 26 & 29 & 35 & 29 & 44 & 38 \\
\hline Peru & 82 & 81 & 76 & 76 & 55 & 50 & 41 & 41 & 39 \\
\hline Slovenia & 33 & 33 & 34 & 34 & 37 & 41 & 46 & 37 & 40 \\
\hline Chile & 53 & 44 & 54 & 40 & 40 & 37 & 44 & 45 & 41 \\
\hline Czechia & 39 & 29 & 30 & 37 & 43 & 42 & 45 & 48 & 42 \\
\hline
\end{tabular}


Table 15 (continued)

\begin{tabular}{|c|c|c|c|c|c|c|c|c|c|}
\hline Country & 2010 & 2011 & 2012 & 2013 & 2014 & 2015 & 2016 & 2017 & 2018 \\
\hline Romania & 77 & 67 & 66 & 54 & 49 & 46 & 42 & 46 & 43 \\
\hline Latvia & 87 & 85 & 88 & 66 & 63 & 66 & 53 & 47 & 44 \\
\hline Kenya & 54 & 59 & 59 & 60 & 64 & 57 & 62 & 59 & 45 \\
\hline Benin & 85 & 46 & 49 & 47 & 44 & 44 & 48 & 51 & 46 \\
\hline Jordan & 63 & 70 & 72 & 59 & 50 & 53 & 54 & 57 & 47 \\
\hline Costa Rica & 98 & 57 & 55 & 71 & 59 & 61 & 52 & 55 & 48 \\
\hline Israel & 65 & 80 & 78 & 81 & 53 & 67 & 55 & 58 & 49 \\
\hline India & 48 & 49 & 45 & 41 & 42 & 48 & 50 & 53 & 50 \\
\hline Qatar & 60 & 47 & 69 & 32 & 33 & 34 & 39 & 39 & 51 \\
\hline Mexico & 55 & 51 & 60 & 52 & 75 & 72 & 59 & 63 & 52 \\
\hline Poland & 52 & 50 & 51 & 53 & 56 & 60 & 63 & 61 & 53 \\
\hline Uganda & 47 & 45 & 39 & 43 & 38 & 36 & 43 & 36 & 54 \\
\hline Turkmenistan & 88 & 79 & 75 & 69 & 65 & 65 & 64 & 60 & 55 \\
\hline Madagascar & 58 & 66 & 62 & 49 & 47 & 51 & 56 & 66 & 56 \\
\hline Malaysia & 42 & 43 & 48 & 51 & 51 & 55 & 57 & 65 & 57 \\
\hline Bangladesh & 44 & 54 & 43 & 39 & 54 & 56 & 51 & 52 & 58 \\
\hline Russian Federation & 135 & 108 & 118 & 97 & 60 & 63 & 69 & 72 & 59 \\
\hline Niger & 71 & 63 & 52 & 48 & 45 & 39 & 36 & 50 & 60 \\
\hline Papua New Guinea & 46 & 58 & 44 & 74 & 70 & 58 & 71 & 64 & 61 \\
\hline Iceland & 75 & 68 & 67 & 62 & 52 & 40 & 47 & 49 & 62 \\
\hline Botswana & 40 & 48 & 56 & 80 & 86 & 95 & 91 & 82 & 63 \\
\hline China & 68 & 74 & 65 & 82 & 84 & 82 & 85 & 73 & 64 \\
\hline Algeria & 94 & 90 & 108 & 83 & 77 & 74 & 75 & 74 & 65 \\
\hline Timor-Leste & 51 & 55 & 57 & 65 & 68 & 73 & 73 & 70 & 66 \\
\hline Marshall Islands & 17 & 15 & 46 & 56 & 57 & 59 & 61 & 78 & 67 \\
\hline Cyprus & 78 & 76 & 80 & 85 & 74 & 62 & 60 & 54 & 68 \\
\hline Estonia & 66 & 72 & 86 & 89 & 81 & 78 & 70 & 69 & 69 \\
\hline Belarus & 106 & 109 & 109 & 99 & 128 & 84 & 78 & 80 & 70 \\
\hline Tajikistan & 56 & 60 & 58 & 61 & 69 & 70 & 68 & 83 & 71 \\
\hline Ghana & 110 & 131 & 101 & 120 & 103 & 104 & 96 & 89 & 72 \\
\hline Gabon & 57 & 65 & 61 & 58 & 66 & 54 & 65 & 68 & 73 \\
\hline Morocco & 80 & 84 & 81 & 68 & 72 & 69 & 72 & 76 & 74 \\
\hline Kazakhstan & 83 & 97 & 83 & 78 & 82 & 75 & 76 & 84 & 75 \\
\hline Sierra Leone & 144 & 128 & 99 & 102 & 98 & 101 & 82 & 86 & 76 \\
\hline Egypt & 61 & 64 & 70 & 70 & 78 & 76 & 86 & 87 & 77 \\
\hline Panama & 59 & 53 & 47 & 46 & 48 & 47 & 49 & 56 & 78 \\
\hline Chad & 132 & 124 & 123 & 131 & 135 & 107 & 106 & 122 & 79 \\
\hline Vanuatu & 62 & 77 & 53 & 84 & 85 & 81 & 94 & 62 & 80 \\
\hline Ecuador & 67 & 69 & 77 & 79 & 80 & 85 & 84 & 94 & 81 \\
\hline Singapore & 79 & 86 & 79 & 86 & 83 & 80 & 80 & 91 & 82 \\
\hline Bulgaria & 115 & 127 & 95 & 103 & 110 & 111 & 88 & 97 & 83 \\
\hline Turkey & 119 & 118 & 121 & 98 & 96 & 79 & 77 & 79 & 84 \\
\hline
\end{tabular}


Table 15 (continued)

\begin{tabular}{|c|c|c|c|c|c|c|c|c|c|}
\hline Country & 2010 & 2011 & 2012 & 2013 & 2014 & 2015 & 2016 & 2017 & 2018 \\
\hline Angola & 155 & 145 & 110 & 91 & 92 & 77 & 83 & 77 & 85 \\
\hline Oman & 72 & 78 & 73 & 57 & 58 & 71 & 66 & 67 & 86 \\
\hline Tunisia & 101 & 91 & 93 & 88 & 87 & 88 & 90 & 98 & 87 \\
\hline Suriname & 95 & 87 & 84 & 92 & 95 & 89 & 98 & 85 & 88 \\
\hline Indonesia & 109 & 106 & 96 & 93 & 91 & 83 & 81 & 92 & 89 \\
\hline United Arab Emirates & 123 & 88 & 85 & 63 & 62 & 68 & 67 & 88 & 90 \\
\hline Solomon Islands & 91 & 83 & 104 & 105 & 88 & 86 & 87 & 81 & 91 \\
\hline Monaco & 84 & 93 & 97 & 90 & 94 & 91 & 92 & 38 & 92 \\
\hline Burkina Faso & 70 & 56 & 64 & 42 & 67 & 52 & 58 & 71 & 93 \\
\hline Eswatini & 74 & 71 & 71 & 87 & 116 & 113 & 95 & 95 & 94 \\
\hline Saudi Arabia & 81 & 82 & 87 & 75 & 73 & 96 & 79 & 90 & 95 \\
\hline Nepal & 96 & 98 & 90 & 107 & 104 & 100 & 99 & 99 & 96 \\
\hline Slovakia & 50 & 61 & 50 & 67 & 61 & 64 & 74 & 93 & 97 \\
\hline Trinidad and Tobago & 114 & 130 & 122 & 111 & 124 & 121 & 112 & 105 & 98 \\
\hline Bolivia (Plurinational State of) & 76 & 75 & 68 & 73 & 89 & 97 & 89 & 102 & 99 \\
\hline Republic of North Macedonia & 125 & 134 & 131 & 101 & 100 & 106 & 103 & 101 & 100 \\
\hline Nigeria & 49 & 52 & 41 & 55 & 79 & 102 & 104 & 103 & 101 \\
\hline Togo & 141 & 111 & 113 & 125 & 99 & 103 & 109 & 114 & 102 \\
\hline Fiji & 128 & 116 & 105 & 132 & 101 & 125 & 115 & 109 & 103 \\
\hline Palau & 36 & 39 & 32 & 77 & 76 & 94 & 93 & 34 & 104 \\
\hline Kuwait & 137 & 138 & 130 & 124 & 107 & 105 & 102 & 118 & 105 \\
\hline Senegal & 118 & 99 & 98 & 109 & 102 & 93 & 100 & 107 & 106 \\
\hline Cambodia & 121 & 117 & 114 & 123 & 117 & 112 & 105 & 104 & 107 \\
\hline Kyrgyzstan & 131 & 104 & 111 & 113 & 106 & 109 & 111 & 112 & 108 \\
\hline Ethiopia & 97 & 100 & 91 & 96 & 109 & 99 & 101 & 100 & 109 \\
\hline Nicaragua & 120 & 121 & 117 & 94 & 93 & 87 & 107 & 108 & 110 \\
\hline Cote d'Ivoire & 143 & 141 & 138 & 118 & 115 & 119 & 130 & 106 & 111 \\
\hline Hungary & 105 & 95 & 94 & 108 & 112 & 108 & 133 & 130 & 112 \\
\hline Cameroon & 113 & 94 & 124 & 121 & 97 & 90 & 97 & 96 & 113 \\
\hline Belize & 93 & 101 & 103 & 104 & 111 & 92 & 126 & 126 & 114 \\
\hline Republic of Moldova & 166 & 147 & 134 & 110 & 105 & 110 & 116 & 116 & 115 \\
\hline Uzbekistan & 146 & 150 & 144 & 135 & 137 & 133 & 128 & 123 & 116 \\
\hline Mauritius & 89 & 89 & 100 & 115 & 118 & 122 & 134 & 111 & 117 \\
\hline Liberia & 162 & 146 & 146 & 138 & 136 & 138 & 125 & 134 & 118 \\
\hline Congo & 142 & 142 & 142 & 137 & 120 & 134 & 114 & 115 & 119 \\
\hline Azerbaijan & 108 & 113 & 119 & 117 & 121 & 114 & 113 & 120 & 120 \\
\hline Georgia & 159 & 125 & 125 & 129 & 129 & 115 & 124 & 131 & 121 \\
\hline Armenia & 150 & 136 & 127 & 122 & 123 & 120 & 123 & 119 & 122 \\
\hline Guatemala & 127 & 92 & 82 & 95 & 90 & 98 & 108 & 110 & 123 \\
\hline Guinea-Bissau & 107 & 120 & 106 & 127 & 127 & 130 & 118 & 117 & 124 \\
\hline Dominica & 133 & 135 & 136 & 140 & 133 & 128 & 120 & 121 & 125 \\
\hline Lebanon & 177 & 153 & 152 & 126 & 119 & 117 & 131 & 136 & 126 \\
\hline
\end{tabular}


Table 15 (continued)

\begin{tabular}{|c|c|c|c|c|c|c|c|c|c|}
\hline Country & 2010 & 2011 & 2012 & 2013 & 2014 & 2015 & 2016 & 2017 & 2018 \\
\hline Pakistan & 130 & 102 & 92 & 100 & 153 & 151 & 127 & 138 & 127 \\
\hline Jamaica & 90 & 96 & 116 & 112 & 131 & 129 & 121 & 133 & 128 \\
\hline Montenegro & 136 & 144 & 143 & 119 & 122 & 131 & 132 & 139 & 129 \\
\hline Dominican Republic & 86 & 105 & 115 & 116 & 126 & 123 & 110 & 135 & 130 \\
\hline Serbia & 145 & 143 & 150 & 141 & 142 & 139 & 137 & 142 & 131 \\
\hline Yemen & 73 & 62 & 63 & 72 & 71 & 116 & 117 & 113 & 132 \\
\hline Namibia & 140 & 152 & 148 & 139 & 141 & 135 & 143 & 141 & 133 \\
\hline Guyana & 165 & 177 & 174 & 174 & 179 & 171 & 158 & 143 & 134 \\
\hline Zimbabwe & 148 & 155 & 149 & 144 & 144 & 136 & 129 & 132 & 135 \\
\hline Brunei Darussalam & 124 & 123 & 132 & 133 & 134 & 124 & 138 & 126 & 136 \\
\hline Equatorial Guinea & 161 & 162 & 156 & 154 & 154 & 145 & 145 & 144 & 137 \\
\hline Djibouti & 99 & 103 & 89 & 106 & 125 & 126 & 136 & 146 & 138 \\
\hline Venezuela (Bolivarian Republic of) & 102 & 107 & 102 & 114 & 108 & 118 & 119 & 137 & 139 \\
\hline Kiribati & 182 & 181 & 181 & 179 & 151 & 147 & 146 & 126 & 140 \\
\hline Grenada & 170 & 154 & 157 & 155 & 156 & 148 & 135 & 140 & 141 \\
\hline Somalia & 151 & 164 & 158 & 161 & 160 & 159 & 150 & 151 & 142 \\
\hline Ukraine & 117 & 119 & 120 & 64 & 149 & 156 & 151 & 152 & 143 \\
\hline Guinea & 134 & 139 & 137 & 146 & 143 & 141 & 148 & 148 & 144 \\
\hline Sao Tome and Principe & 152 & 149 & 153 & 151 & 148 & 143 & 149 & 149 & 145 \\
\hline Tonga & 122 & 129 & 128 & 142 & 147 & 144 & 147 & 154 & 146 \\
\hline Bahrain & 100 & 112 & 135 & 143 & 138 & 146 & 139 & 155 & 147 \\
\hline Gambia & 103 & 132 & 112 & 134 & 113 & 137 & 122 & 145 & 148 \\
\hline El Salvador & 129 & 140 & 129 & 148 & 146 & 140 & 144 & 153 & 149 \\
\hline Colombia & 154 & 158 & 160 & 160 & 163 & 164 & 160 & 158 & 150 \\
\hline Cabo Verde & 157 & 159 & 159 & 158 & 161 & 165 & 152 & 126 & 151 \\
\hline Tuvalu & 69 & 137 & 139 & 153 & 157 & 157 & 155 & 75 & 152 \\
\hline Bahamas & 92 & 160 & 147 & 157 & 145 & 153 & 157 & 168 & 153 \\
\hline Democratic People's Republic of Korea & 153 & 151 & 155 & 156 & 159 & 163 & 164 & 161 & 154 \\
\hline Albania & 149 & 157 & 151 & 147 & 152 & 150 & 153 & 160 & 155 \\
\hline Saint Kitts and Nevis & 111 & 114 & 141 & 150 & 140 & 154 & 173 & 169 & 156 \\
\hline Mauritania & 147 & 156 & 166 & 163 & 158 & 162 & 161 & 164 & 157 \\
\hline Mali & 104 & 110 & 175 & 170 & 171 & 176 & 169 & 166 & 158 \\
\hline Andorra & 167 & 166 & 167 & 164 & 170 & 167 & 154 & 126 & 159 \\
\hline Iran (Islamic Republic of) & 116 & 133 & 107 & 130 & 130 & 127 & 140 & 147 & 160 \\
\hline Seychelles & 176 & 170 & 171 & 176 & 173 & 170 & 141 & 150 & 161 \\
\hline Cuba & 163 & 165 & 164 & 166 & 165 & 161 & 159 & 163 & 162 \\
\hline Mongolia & 164 & 169 & 162 & 162 & 162 & 160 & 163 & 157 & 163 \\
\hline Rwanda & 171 & 168 & 161 & 167 & 169 & 168 & 175 & 176 & 164 \\
\hline Democratic Republic of the Congo & 175 & 176 & 163 & 159 & 166 & 152 & 165 & 167 & 165 \\
\hline Antigua and Barbuda & 139 & 115 & 133 & 149 & 139 & 132 & 142 & 162 & 166 \\
\hline San Marino & 160 & 148 & 154 & 152 & 155 & 155 & 166 & 126 & 167 \\
\hline Honduras & 112 & 122 & 126 & 136 & 114 & 142 & 156 & 156 & 168 \\
\hline
\end{tabular}


Table 15 (continued)

\begin{tabular}{|c|c|c|c|c|c|c|c|c|c|}
\hline Country & 2010 & 2011 & 2012 & 2013 & 2014 & 2015 & 2016 & 2017 & 2018 \\
\hline Croatia & 172 & 174 & 173 & 175 & 178 & 175 & 172 & 171 & 169 \\
\hline Barbados & 126 & 126 & 140 & 145 & 150 & 149 & 168 & 165 & 170 \\
\hline Libya & 138 & 161 & 145 & 128 & 132 & 158 & 167 & 159 & 171 \\
\hline Bosnia and Herzegovina & 181 & 183 & 184 & 168 & 168 & 169 & 170 & 170 & 172 \\
\hline Iraq & 180 & 172 & 178 & 169 & 164 & 166 & 162 & 173 & 173 \\
\hline Central African Republic & 174 & 178 & 176 & 178 & 180 & 179 & 178 & 174 & 174 \\
\hline Maldives & 158 & 163 & 165 & 165 & 167 & 172 & 174 & 172 & 175 \\
\hline Afghanistan & 173 & 175 & 172 & 177 & 172 & 174 & 179 & 177 & 176 \\
\hline Burundi & 169 & 171 & 169 & 171 & 175 & 180 & 176 & 179 & 177 \\
\hline Sudan & 156 & 167 & 168 & 172 & 176 & 173 & 171 & 175 & 178 \\
\hline South Sudan & 41 & 30 & 170 & 173 & 177 & 178 & 182 & 184 & 179 \\
\hline Sri Lanka & 183 & 184 & 179 & 181 & 181 & 181 & 177 & 178 & 180 \\
\hline Vietnam & 168 & 173 & 182 & 182 & 184 & 184 & 184 & 181 & 181 \\
\hline Saint Vincent and the Grenadines & 178 & 179 & 180 & 183 & 183 & 182 & 180 & 180 & 182 \\
\hline Nauru & 191 & 188 & 190 & 190 & 174 & 177 & 185 & 183 & 183 \\
\hline Saint Lucia & 179 & 180 & 177 & 180 & 182 & 183 & 181 & 185 & 184 \\
\hline Eritrea & 187 & 190 & 183 & 184 & 185 & 185 & 183 & 182 & 185 \\
\hline Haiti & 188 & 187 & 188 & 188 & 187 & 189 & 187 & 189 & 186 \\
\hline Comoros & 184 & 185 & 185 & 186 & 189 & 188 & 188 & 186 & 187 \\
\hline Micronesia (Federated States of) & 186 & 186 & 186 & 185 & 188 & 186 & 186 & 187 & 188 \\
\hline Lao People's Democratic Republic & 189 & 189 & 187 & 189 & 190 & 190 & 190 & 190 & 189 \\
\hline Syrian Arab Republic & 185 & 182 & 189 & 187 & 186 & 187 & 189 & 188 & 190 \\
\hline Bhutan & 191 & 192 & 192 & 192 & 192 & 192 & 192 & 191 & 191 \\
\hline Myanmar & 190 & 191 & 191 & 191 & 191 & 191 & 191 & 192 & 192 \\
\hline
\end{tabular}

\subsubsection{Results}

Using the index construction methods developed by this project (see the methodology section), this sub-index ranks 192 countries from 2010 to 2018 according to their level of performance in and contribution to global justice in the issue area of refugee governance (see Table 15).

The total number of refugees in the world has been rising over the past ten years, with the number almost doubling from 2010 to 2018. The year 2018 brought many challenges to global refugee governance, including the crises in Bangladesh (Rohingya refugees), Venezuela, Syria and Yemen, as well as conflicts in the Democratic Republic of the Congo and the Central African Republic, which have forced a growing number of destitute and vulnerable people to flee their home countries and take refuge beyond their borders. Regarding the geographic distribution of the refugees' countries of origin, the three regions that generated the most refugees were West Asia, East Africa, and Southeast Asia. West Asia (the Middle East) exported 7.27 million refugees in 2019, East Africa 
exported 4.5 million, and Southeast Asia exported 3.1 million. Meanwhile, the three regions that hosted the most refugees are West Asia, Southeast Asia, and East Africa. There were nearly 5.8 million refugees that moved to West Asia in 2019, 3.54 million in Southeast Asia, and 3.42 million in East Africa. Therefore, it is easy to identify that most refugee flows were actually between countries in the same region, rather than across regions. For example, in 2019, 76\% of all refugees from West Asia flowed into neighboring countries in West Asia, and 80\% of refugees from South Asia flowed into other countries in South Asia.

In 2018, the countries that exported the most refugees worldwide were Syria, Afghanistan, South Sudan, Myanmar, and Somalia. The first four countries exported more than 1 million refugees, of which Syria exported 6.65 million refugees (accounting for $33 \%$ of all refugees), which is nearly 2.5 times the second place origin country of Afghanistan (2.68 million). In 2018, the countries that received the most refugees in the world were Turkey, Pakistan, Uganda, Sudan and Germany. Turkey leads the world, and has received nearly 3.68 million refugees (45 refugees per 1,000 citizens. As a share of the population, Lebanon hosts by far the most with 156 refugees per 1000 citizens. Jordan came second in 2018, receiving 72 per 1,000 of its national population. ${ }^{74}$ In recent years, the flow of refugees toward the European Union generated by the prolonged conflict in Syria has captured headlines across the world, but they are in fact only part of a much broader story. For the past decade, most refugees actually cannot afford to travel to these developed countries, rather they have no choice but to flee into neighboring poorer countries. The largest refugee host countries are the developing countries next to the countries of origin (see Fig. 11). The Norwegian Refugee Council has noted that since 2018 "borders have closed for families seeking protection, refugee quotas slashed, and poor host countries left with little international support." 75 The situation for these developing countries hosting refugees is worrying, but they have not attracted sufficient attention in the media and academia.

The intensified refugee crisis is a global issue that calls for common participation and differentiated contribution by individual countries. Over the past decade, varying degrees of progress have been made by individual countries in governing the refugee issue. Among the ten countries ranked top in 2018 (see Fig. 12), nine are in Europe (including Sweden, France, Germany, Spain, the UK, Switzerland, Finland, Ireland, and Slovenia) and one belongs to North America (Canada). The world map below shows the ranking of all observed countries in 2018.

Sweden ranked top in 2018 according to its performance and contribution to refugee governance, a position it has held since 2012 (with the exception of 2017). Sweden has taken refugees for decades. The number of refugees seeking shelter in Sweden has increased over the past 10 years. During 2015 Sweden accepted more refugees per capita than any other country in the EU (163,000 people, almost $2 \%$

\footnotetext{
74 Nandini Krishnan et al. (2020).

75 See https://reliefweb.int/report/world/global-refugee-forum-broken-promises-must-end-now (accessed December 8, 2020).
} 
of the total population). ${ }^{76}$ This is followed by other developed countries, including France, Germany, Spain, the United Kingdom, Switzerland, Finland, Canada, Ireland and Belgium. These traditional resettlement states have expanded the numbers of refugees they host and put forward policy measures to protect refugees' rights and ensure their access to basic and essential goods. However, there is a mixed trend with regard to refugee policies in these countries. On the one hand, these refugeehosting countries have overall moved considerably towards more comprehensive policies to save lives and protect newcomers, and many have recognized the potential economic and social contributions refugees can make. Some host countries have even undertaken dedicated measures to facilitate refugee integration, minimize disparities between refugees and nationals, and help build a future for refugee families. For example, Sweden tries to project a strong welfare state by offering refugees publicly funded integration programs which help the newcomers get Swedish language lessons and learn about the culture. ${ }^{77}$ On the other hand, more restrictive legal approaches have been introduced and implemented in recent years in these countries to block influx of outsiders as the politics around refugee issues became more polarized in these places. Many nationalist, far-right and anti-immigrant political parties have surged and tried to reshape state policies across Europe. ${ }^{78}$ For example, fueled by the refugee crisis since 2015, politicians and parties on the radical right in France, Netherlands and Germany have experienced renewed vigor, pushing for policies to fight "an invasion of foreigners." As a result, the past few years have recorded a deterioration in the situation of refugees in some European countries.

Refugee governance and state stability are linked together. ${ }^{79}$ As of mid-2020, more than two-thirds of the world's refugees come from five countries experiencing civil wars and fragile governments: Syria (6.6 million), Venezuela (3.7 million), Afghanistan (2.7 million), South Sudan (2.3 million) and Myanmar (1.0 million). ${ }^{80}$ Among the states ranked bottom in 2018 , the number of people displaced by conflicts reached a record high in Myanmar, Syria, South Sudan, Afghanistan and Central Africa. Ongoing conflicts, weak states, terrorist attacks, rebels, as well as religious and ethnic fragmentation continued to uproot millions of people, forcing them to leave their homeland. For example, Myanmar is a religiously and ethnically diverse country that has experienced a wide range of conflicts and violence during recent decades. These conflicts have produced a growing number of refugees fleeing across borders. As result of the conflicts that erupted in Myanmar's Rakhine state in August 2017, approximately 720000 Rohingya refugees, nearly $80 \%$ of whom are women and children, have been forced to flee their homes to escape targeted violence and religious repression, causing a humanitarian crisis on a catastrophic scale. In August 2018, the UN Secretary-General António Guterres emphasized that

\footnotetext{
76 See https://www.loc.gov/law/help/refugee-law/sweden.php (accessed December 5, 2020).

77 See https://www.cbsnews.com/news/sweden-rise-of-the-right-immigrants-unwelcome-cbsn-originals/ (accessed December 5, 2020).

78 Cas Mudde (2019).

79 David Scott FitzGerald and Rawan Arar, 2018, The Sociology of Refugee Migration, Annual Review of Sociology 44: 387-406.

80 See https://www.unhcr.org/refugee-statistics/ (accessed December 12, 2020).
} 


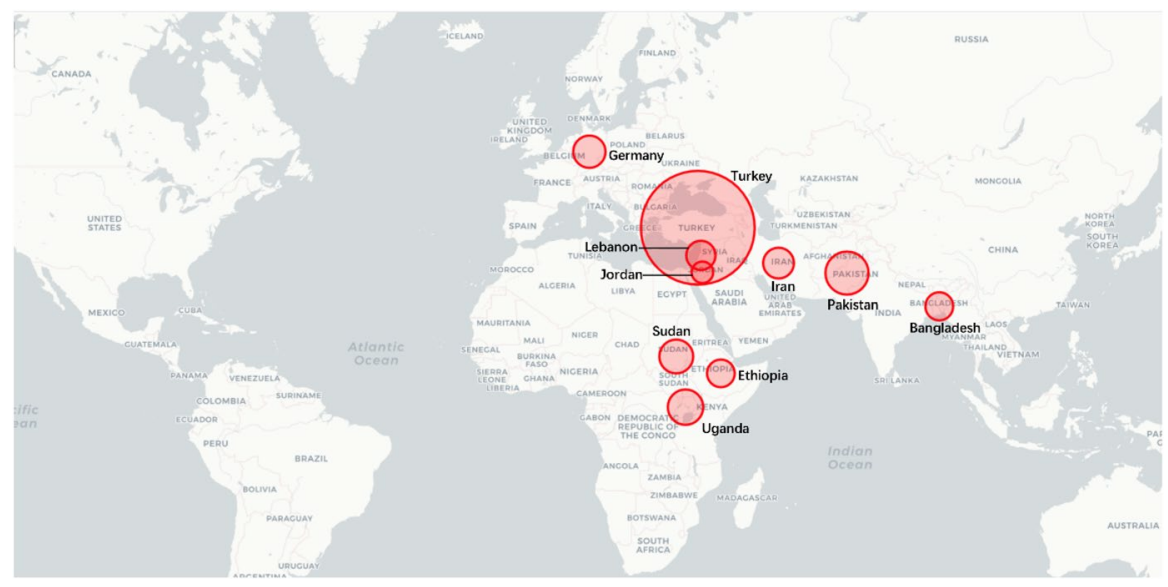

Fig. 11 Refugee Host Countries

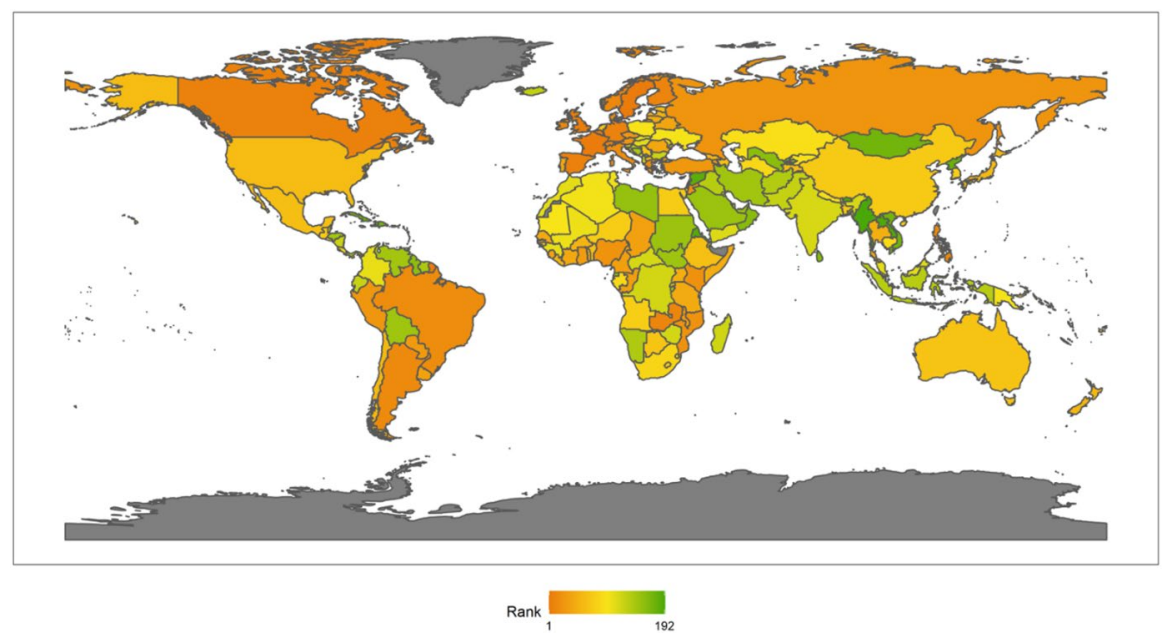

Fig. 122018 Index ranking of refugee governance on a world map

Myanmar's refugee problem has become "one of the world's worst humanitarian and human rights crises" ${ }^{81}$ In Syria, the country has been caught up in prolonged civil war since March 2011. The increased violence and weak state governance have forced a large number of Syrian citizens to flee for refuge, creating the largest refugee population in the world. In 2018, an estimated more than 6.6 million Syrians were on the run after fleeing the conflict, with 5.5 million refugees living

${ }_{81}$ See https://www.un.org/press/en/2018/sc13469.doc.htm (accessed December 14, 2020). 


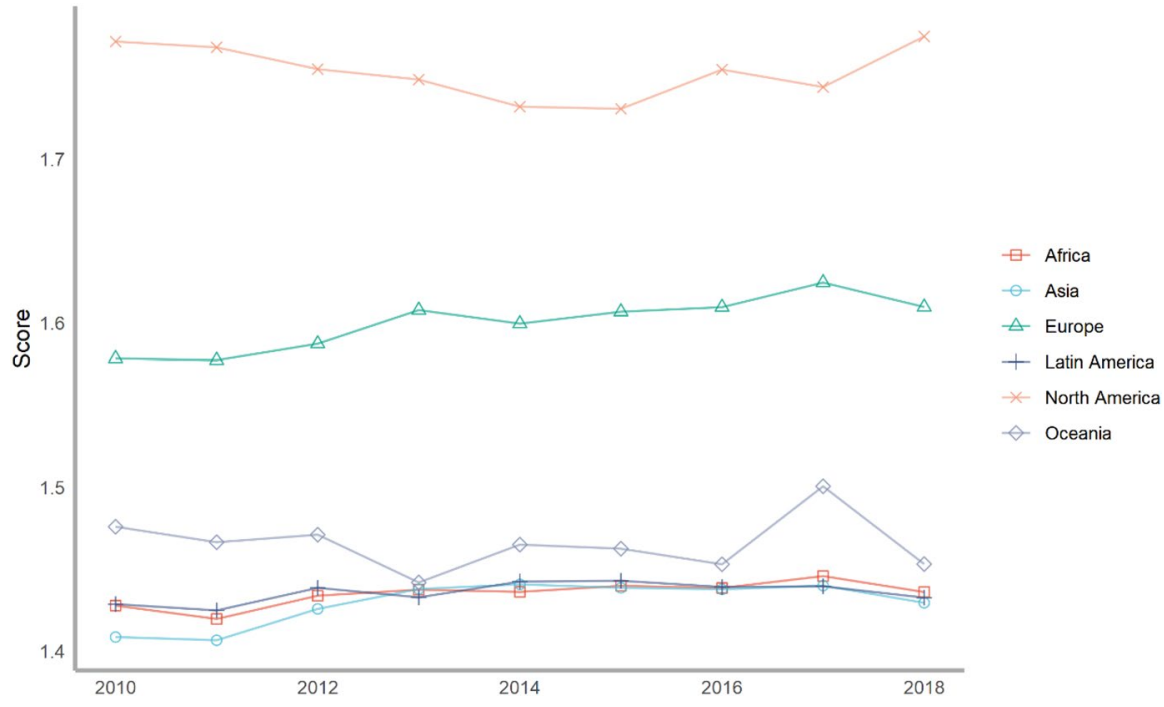

Fig. 13 The score of refugee governance issue across continents, 2010-2018

in countries bordering Syria, including Turkey, Lebanon, Joran, Iraq, and Egypt. ${ }^{82}$ Around half of all registered Syrian refugees are actually under the age of 18 . UNHCR High Commissioner Filippo Grandi called Syria "the biggest humanitarian and refugee crisis of our time, a continuing cause for suffering." Even worse, with no end in sight, a vicious circle remains with respect to refugee issues and regional conflict. The refugee crisis will further exacerbate concerns about regional destabilization in the Middle East, Southeast Asia and East Africa.

\subsubsection{Regional Analysis}

As for regional performance, North America was still ahead in average ranking in 2018, followed by Europe, Oceania, Latin America, Asia and Africa. Nonetheless, the latter four had little difference between them, with the average index scores being at 1.45 and average rankings being in the early 100 s. As shown from Fig. 13, only one of the six regions in the world improved in the global justice of refugee governance in 2018.

Asia Asia is a region with large refugee flows (especially in West Asia and Southeast Asia) but limited legal protection. It has done a great job in the RSD Positive Ratio but was scored low in the RSD Number and International Agreement Participation. Less than half of the countries in this region have acceded to the 1951 Convention and its 1967 Protocol. In the past decade Asia's average ranking has risen slightly, mainly driven by particular improvement in Asia's Refugee Housing Situation. As a large region of tremendous economic, political and social diversity,

${ }^{82}$ See https://www.unrefugees.org/emergencies/syria/ (accessed December 15, 2020). 
refugee governance varied substantially between Asian countries. Five countries in Asia continue to rank in the top 50 of the sub-index: The Philippines, Japan, Thailand, South Korea and Jordan. The Philippines ranks first in the region and 15th globally in 2018. It scored highly in International Agreement Participation, Refugee Policy, and RSD Positive Ratio, despite its low level of refugee hosting. Japan has risen from 43 in 2010 to 22 in 2018, mainly due to the increase in RSDs and a significant improvement in refugees' accommodation situation. Thailand has performed very well in hosting external refugees and developing refugee policies, but did not fully engaged in international agreements and provided less sufficient accommodations for refugees. Turkey continues to be the most generous host state in the world, but it also generated a large number of refugees fleeing from the country and its RSD Positive Rate was kept very low. Jordan represents a similar case: it ranks second in the world in hosting refugees (most are Syrian) but this is offset by its large magnitude of refugee production and its conservatism in refugee policies. Political conflicts and civil wars have been at the root of the largest refugee outflows in the region. Suffering from unresolved conflicts and insecurity, Afghanistan, Syria and Myanmar remained the three largest refugee origin countries of concern to the UN in Asia. There were about 2.2 million Afghan refugees worldwide in 2018, approximately $95 \%$ of whom moved to neighboring Pakistan and Iran. ${ }^{83}$ Myanmar was ranked last in the region and in the global ranking, owing to the Rohingya refugee crisis as well as its poor performance in other respects.

Europe Europe's performance was strong, especially in the two indicators of RSD Number and International Agreement Participation, and it was also at the forefront of other indicators. Over the past 9 years, the average ranking of Europe has slightly improved, from 67 to 61 . This rise was mainly attributed to its decline in exported refugees and increase in international agreement participation. Since the Treaty of Lisbon entered into force in 2009, Europe has developed a comprehensive institutional framework and burden-sharing mechanisms to protect refugees. ${ }^{84}$ While Europe's overall efforts toward promoting global justice in the field of refugee governance can be appreciated, gaps in national refugee governance persist. At the national level, Western Europe occupied 9 of the 10 highest ranking countries globally. Countries like Sweden, France, Germany, Spain, the United Kingdom and Finland have been very stable in the rankings, and are almost always in the top 10. In comparison, Eastern European countries, such as Hungary, Croatia, Slovakia and Bulgaria, ranked relatively low. As the refugee crisis in Europe continued throughout 2018, Eastern European countries always bear the brunt. However, these countries either have very limited institutions and resources to accommodate the high arrival of refugees or have simply adopted restrictive policies to stop newcomers at the borders. For example, in 2018, Hungary closed its borders to nearly all the

\footnotetext{
${ }^{83}$ Executive Committee of the High Commissioner, Update of UNHCR's Operations in Asia and the Pacific, 14 September 2018.

84 Paolo Biondi, (2016).
} 
refugees as Prime Minister Viktor Orban and his ruling Fidesz Party adopted an anti-refugee policy ("zero refugee" policy). ${ }^{85}$

North America North America was leading the world and maintained its ranking of around 20th from 2010 to 2018, with a slight overall improvement in score of 0.04. Both Canada and the United States have performed well and steadily, although there is a small disparity in refugee governance between the two countries in the North America. Canada has maintained a ranking of around 10th in the past 9 years, and the United States has held its position at around 30th. Canada has done very well in RSD Number and exporting few refugees, ranking in the top 20th in the world. It has also done well in Receiving Refugees, RSD Positive Ratio, Domestic Refugee Policy, and Housing Situation, ranking around 25th to 50th. A relatively lower-scoring aspect was its participation in the international convention, which ranked around the middle globally. Over the past 9 years, Canada's score in Receiving Refugees has dropped by 0.06, and its score in RSD Number has dropped significantly by 0.33 , but the RSD Positive Ratio experienced an improvement in score of more than 0.1 . The United States has done very well in the three aspects of Receiving Refugees, Exporting Refugees, and RSD Number, which were all ranked in the top 20th in the world. Besides, it ranked in the middle of the world in RSD Positive Ratio and Housing Situation. However, the United States participated in relatively few international conventions, which has dragged down its whole score. In the past few years, it has declined in Receiving Refugees.

Latin America Latin America performed relatively poorly, with a sub-index average score of 1.143 in 2018, a score which dropped by 0.1 over the past 4 years, mainly due to the decline in RSDs. The continent performed moderately in areas like Housing Situation, but was falling far behind in areas like National Policies and RSD Positive Ratio. Within the region, there was an obvious performance disparity among the different sub-regions. South American countries such as Argentina, Brazil, Uruguay, Paraguay, Peru, Chile were performing relatively better than Central America and much better than the Caribbean countries. For example, Argentina was ranked 13th globally in 2018, while Mexico was 52nd and Haiti ranked at the bottom, 186th in 2018. The main drivers of displacement in the Caribbean region included natural disasters, gang violence, persistent poverty and fragile states. Natural disasters especially severe storms caused by the effects of global climate change constituted a major cause refugee movement in the Caribbean. For instance, in Haiti, the earthquake of 2010 killed more than 310,000 Haitians and displaced at least 1.5 million. Meanwhile, years of hurricanes, floods and mudslides coupled with weak state governance further exacerbated the refugee crisis in Haiti. An exception in South America is Venezuela which is ranked 139th in the world. Venezuela has been stuck in political and economic crisis for several years, which has produced a large number of refugees, with most travelling towards the Caribbean and other South American countries. After the 2018 election, the situation got even worse, which forced 350000 new refugees to flee Venezuela in 2018 alone due to violence,

\footnotetext{
85 See https://www.theguardian.com/world/2018/jun/04/no-entry-hungarys-crackdown-on-helping-refug ees.
} 
insecurity, extreme levels of unemployment and shortages of daily necessities and medication. ${ }^{86}$

Africa Africa also scored low, with an average ranking of 108 in 2018, a performance which has been very stable over the past decade. Africa has done very well in terms of Receiving Refugees and RSD Positive Ratio. However, it is also the continent with the most severe export of refugees and the lowest score for Refugee Accommodation Situation. There are some notable intra-regional variations with regard to refugee governance in Africa. The refugee situations in Central Africa and East Africa continued to deteriorate due to widespread violence and conflicts between various armed groups, coupled with other factors including famine, drought, poverty, public health crises and failed states. The Central African Republic, the Democratic Republic of the Congo, Libya, Somalia, Burundi and South Sudan exported the largest number of refugees in the region because of their severe humanitarian situations. In the Central African Republic alone, at least 568 000 refugees had fled to neighboring countries as of mid-2018. The instability of South Sudan created one of the most protracted displacement situations in the world, forcing an estimated 2.5 million refugees to flee their homes. ${ }^{87}$ These countries were also ranked low in International Agreement Participation, Refugee Policies, and Refugee Accommodation Situation. Some West African countries are also facing similar crises. Prolonged armed conflicts, terrorism and ethnic repression, compounded by growing poverty, food shortages, and the climate crisis, have triggered significant refugee movements across borders from Nigeria, Mali and Mauritania to neighboring states. In North Africa, Morocco and Egypt performed well in receiving new refugee arrivals and provide asylum policies. The unstable situation in Libya, characterized by armed conflicts and political fragmentation, has displaced hundreds of thousands of people to other African countries and to Southern Europe (through the Central Mediterranean route). It is also not party to the 1951 Convention and has no concrete refugee policies, let alone the provision of decent accommodation facilities. ${ }^{88}$ Southern Africa has been a relatively stable sub-region in the African continent. Mozambique and Zambia are the best performers in Africa, maintaining a ranking of around 20. These two countries have achieved full marks in the two indicators of International Agreement Participation and Domestic Refugee Policy. Zambia continued to host a large Congolese refugee population.

Oceania Oceania performed reasonably well, with an average ranking of 100 . It was the continent producing and exporting least refugees, but it scored low in receiving refugees and international refugee-agreement participation. Simultaneously, despite a slight improvement in its averaged score (see Fig. 6.2) the overall ranking of Oceania has deteriorated slightly over the past 9 years, from 87 in 2010

\footnotetext{
86 The UN Refugee Agency, 2018, Global Trends: Forced Displacement in 2018, available at: https:// www.unhcr.org/globaltrends2018/ (accessed December 17, 2020).

87 Executive Committee of the High Commissioner's Programme, Update of UNHCR's operations in Africa, 1-5 October 2018.

${ }^{88}$ Libya even run detention centers where to hold returners, refugees and asylum seekers for indefinite periods. See the UN Refugee Agency, UNHCR Position on Returns to Libya (Update II), September 2018.
} 
to 100 in 2018, mainly due to the decline in the number of RSDs and the significant fluctuations in RSD's positive ratio during the past decade. Australia and Samoa are ranked first and second at the national level in the region, with their rankings maintaining above 30th place over the past decade. New Zealand follows closely behind, stabilizing in the top 40. According to the Refugee council of Australia, Australia recognized or resettled 23,002 refugees in 2018 (1.39\% of the global total). However, Australia was also criticized for its refugee policies which did not respond well to the large number of asylum-seeker arrivals and therefore not a model for the world as its leader claimed. ${ }^{89}$ Moreover, Australia has introduced a policy of "offshore processing centers" in Nauru and Papua New Guinea since 2012, which was designed to stop refugees arriving in Australia by sea without a valid visa. This policy has been increasingly condemned by many international organizations.

It can be observed that the origin and distribution of refugees have showcased certain obvious regional features. This is largely driven by the fact that unresolved regional conflicts and insecurity have resulted in a growing number of forced migrations and presented major challenges to the effective governance of refugee crises. Therefore, the issue of how regional bodies and individual countries in the same region might cooperate with each other to manage refugees, respond to the needs of people on the move, and create new initiatives to protect newcomers, has become more important and relevant than ever. ${ }^{90}$ Much effort has already been given to regional cooperation on refugee governance, for instance in the Solutions Strategy for Afghan Refugees, the Nairobi Declaration and Plan of Action on Durable Solutions for Somali Refugees and Reintegration of Returnees in Somalia, the Comprehensive Regional Protection and Solutions Framework for Central America and Mexico, and Asia Pacific Refugee Rights Network's Vision for Regional Protection. With record numbers of people displaced around the world, comprehensive regional approaches with contributions from individual countries have become increasingly crucial in addressing this common crisis.

\subsubsection{Conclusion}

Refugee problems continue to pose a great challenge to the fulfillment of global justice. Forced and irregular displacement will lead to economic, social and political crisis in countries of origin, transit and destination, as well as insecurity for refugees themselves. Individual countries play a pivotal role in providing policies and assistance for managing the crisis in the short, medium, and long term. This subindex ranks countries' performance and contribution to refugee governance, which is designed to encourage both origin and host countries to address refugee protection and enhance global justice in a more comprehensive manner.

As shown in the above analysis, there has been a great disparity in state performance in multiple aspects of refugee governance among different regions and

\footnotetext{
89 John et al. (2018) Australia's Refugee Policy: Not a Model for the World, International Studies 55 (1): $1-21$.

90 Susan Kneebone (2016).
} 
sub-regions, between developed countries and developing countries, between origin countries and host countries and between neighboring countries and far-away countries. The occurrence and deterioration of the refugee crisis is closely associated with armed conflicts, growing poverty, natural disasters and weak state capacity.

In order to effectively improve global justice in the domain of refugee governance, cooperation between various actors, including host countries, countries of origin, regional organizations, NGOs and UN agencies, will be undoubtedly critical to offering sustainable and comprehensive responses.

For refugee host countries, although large refugee flows have fueled xenophobic reactions and conservative migration policies in the West, these developed countries are responsible for doing more in either meeting basic needs and addressing logistical issues in short term or providing a complex institutional framework and policy measures in the long run. Because the refugee issue is a global humanitarian crisis requiring more equal burden-sharing. Developing countries next to the center of origin currently host much larger refugee populations than the Western countries that control the media discourse. For origin countries, many governments have long suffered political instability, weak state capacity, fragmented power, armed conflicts, widespread poverty, resource shortages and a lack of governance. Prevention is always better than cure. In order to address the root causes of refugee problems, more concerted and thorough efforts need to be conducted by origin countries (with support from international organizations) to promote peacebuilding, enhance economic development, reduce poverty and improve good governance. Only through these measures on multiple levels can individual countries escape the cycle of bad governance, exile, worse governance and more exile. In addition, conflict prevention and good governance will also attract more returnees back to their homelands and strengthen the resilience of their livelihoods, which will in the long term alleviate the severity of the refugee crisis in other places.

The global refugee crisis represents one of the key challenges towards achieving the objective of the 2030 Agenda for Sustainable Development adopted by the United Nations General Assembly. In today's world where anti-migration sentiments, nationalism and populism have gained ground, it seems more critical to develop differentiated but concerted measures for refugee governance and ensure solidarity and partnership among relevant stakeholders. More country-level plans and actions, with support from regional actors and the international community, ${ }^{91}$ are expected to be implemented, in order for individual national states to contribute to global justice by supporting people of concern and transforming the way they respond to refugee situations.

\footnotetext{
91 For example, the United Nations General Assembly affirmed the "Global Compact on Refugees" in 2018. The Compact provides "a blueprint for governments, international organizations, and other stakeholders to ensure that host communities get the support they need and that refugees can lead productive lives." See https://www.unhcr.org/gcr/GCR_English.pdf (accessed December 24, 2020).
} 


\subsection{Issue 7: Anti-poverty}

\subsubsection{Introduction}

Global poverty is one of the very worst and most urgent global justice problems currently facing the world. It presents a great threat to human development and to social, economic and political stability. According to estimates by the World Bank, as of 2018, at least $9 \%$ of the world's people lived in extreme poverty, which is defined as living on only US\$1.90 a day or less based on 2011 purchasing power parity (PPP). If we raise it to more moderate poverty lines, roughly $24 \%$ of the world's population live on less than $\$ 3.20$ a day and $43 \%$ on less than $\$ 5.50$ a day. ${ }^{92}$ Poverty alleviation is of substantial importance to improving global justice. "Leave no one behind" is the central promise and the rallying cry of the 2030 Agenda for Sustainable Development. The past three decades have witnessed remarkable and unprecedented progress toward the goal of poverty alleviation, with the share of the global population living in extreme poverty continuously plunging from $36 \%$ in 1990 to less than $10 \%$ in 2018. Many national governments, especially those in East Asia and Pacific or South Asia, have invested tremendous efforts to confront poverty and reduce inequality. Meanwhile, continuous economic growth and widespread improvements in well-being in middle-income countries have made great contributions to helping tens of millions of desperately poor people escape poverty every year.

Despite this optimistic picture of world poverty reduction, the fight against global poverty is far from successful, and in certain ways is even getting more challenging. There are at least three alarming reasons for concern. First, although global poverty rates have been largely decreasing over the past 30 years, the progress of reducing poverty has been very uneven across different regions and countries of the world. For instance, in Sub-Saharan Africa, the number of extreme poor is unacceptably high and is going to rise further in the coming years, leading to regional concentration of the global poor. Second, the pace of poverty alleviation is gradually slowing down. The poverty reduction effects brought about by economic growth have begun to decrease. The fight against poverty has entered more difficult "deep water areas" where fragile states, poor governance, unresolved conflicts and low-quality infrastructure have become the biggest obstacles to a more equitable and sustainable society. ${ }^{93}$ Third, in 2020, the global crisis of the COVID-19 pandemic posts new challenge to poverty governance. The COVID-19 crisis has disproportionally impacted the world's poor and is estimated to lead to an additional 150 million people falling into extreme poverty over the next 2 years. ${ }^{94}$ This will be the first time in over 20 years that the world will see more new poor than the number of people lifted out of poverty. Growing poverty could cause social tensions, induce political

\footnotetext{
92 World Bank. (2020).

93 World Bank (2018).

94 See https://www.worldbank.org/en/news/press-release/2020/10/07/covid-19-to-add-as-many-as-150million-extreme-poor-by-2021 (accessed December 27, 2020).
} 
conflicts and jeopardize human development in areas such as health, education and mortality. All the above issues make the fight against poverty a more urgent and challenging global project, in which nation-states should shoulder more responsibilities and make more contributions. Without comprehensive plans and swift, significant and substantial policy actions by individual countries, years of achievement in poverty reduction will likely soon be erased. This anti-poverty sub-index, as part of the global justice index, is designed to evaluate individual countries' efforts and performance in poverty reduction, as a means to improve global justice.

\subsubsection{Dimensions and Indicators}

Poverty is a state in which a person lacks a commonly acceptable amount of financial resources and essentials for a minimum standard of living in a particular place. It centers on material deprivations and the inability to satisfy their basic needs. Poverty is closely related to, but must be treated differently frominequality and vulnerability. Inequality emphasizes income or welfare distribution within the whole population; it is often measured by the Gini index. Vulnerability highlights the risk of falling into poverty in the future, which is often influenced by external shocks such as a financial crisis, a natural disaster, or a pandemic. ${ }^{95}$ This sub-index is focused on assessing individual countries' performance in and contribution to global poverty reduction, referring to their achievements in helping the poor to meet basic needs. Therefore, the sub index will restrict itself from stretching its key concept of poverty too much to include dimensions of inequality and vulnerability. Of course, that is by no means to say that inequality and vulnerability are not as important as the problem of poverty; they are certainly of great significance to enhancing social justice. However, given its theoretical definitions, this project will concentrate on the issue area of absolute poverty, measuring and comparing individual countries' contribution to global justice in the domain of protecting the most vulnerable and satisfying people's minimum essential needs.

Although the theoretical and conceptual underpinnings of poverty measurement are anchored in social sciences, ${ }^{96}$ measuring and comparing nation states' performance in poverty governance is still a big challenge. There is no single commonly accepted way to operationalize poverty measurement. Governments around the world have adopted their own indigenous methods to evaluate poverty and set poverty thresholds so as to serve their policy purposes and political aspirations. As a consequence, big cross-national variations can be observed in poverty survey methods, the indicators used, the types of data collected and the ways data are aggregated, thus making it notoriously difficult, if not impossible, to make comparisons of poverty governance across countries and across time. Moreover, there are two basic approaches to considering and measuring poverty. One is to take a "thin"

\footnotetext{
95 Jonathan Haughton and Shahidur R. Khandker. 2009. Handbook of Poverty and Inequality. Washington, DC: World Bank. P.2.

96 David Brady and Linda M. Burton eds. 2016. Oxford Handbook of the Social Science of Poverty. New York: Oxford University Press.
} 
perspective on poverty by measuring it through defining a threshold of individuals' income or consumption below which people are considered as poor. The other is to take a "thick" perspective of poverty by defining it as the command over various specific types of goods such as food, education, health care, longevity and employment. The former is monetarily valued and based on a well-established poverty threshold, such as the measurement used by the World Bank. The latter is often nonmonetary and relies on a sophisticated set of indicators, ${ }^{97}$ for example the Human Development Index (HDI) and the Multidimensional Poverty Index (MPI). ${ }^{98}$

Based on the goods-based conception of global justice and the principle of CDDR (as elaborated in our concept paper), we assume that efforts to combat global poverty should respect the action of individual countries involved in improving the living conditions for the least advantaged within their respective jurisdictions. Therefore, to assess the contributions made by each country to global poverty eradication, we measure their progress in poverty reduction by focusing on two thematic indictors: (1) poverty rate reduction, which measures the "contribution" dimension; and (2) poverty gap, which measures the "performance" dimension. ${ }^{99}$ Doing so achieves a middle ground between a single indicator of poverty measurement (the "thin" approach) and a sophisticated set of indicators for multidimensional measurement (the "thick" approach). ${ }^{100}$ In addition, the present sub-index of anti-poverty is only one of the ten issue areas used to construct the final global justice index. Many indicators included in multidimensional poverty measurement have already be assessed in other issue areas, such as education, public health and protection of women and children.

The World Bank is the main source of globally comparable data on global poverty $^{101}$ and it has defined the widely agreed-upon "International Poverty Line". These poverty lines are set as a scale, ranging from extreme to moderate levels. It is important to emphasize that the international threshold of extreme poverty (consumption expenditure at $\$ 1.9$ per day in $2011 \mathrm{PPP}$ ) is mainly based on and reflects the situations in some of the poorest countries, which is too low to gain a comparable sense of poverty in all countries of the world. In 2017, the World Bank supplemented the international extreme poverty lines with two new ones, tracking global poverty at $\$ 3.20$ a day (the line for lower-middle-income countries) and $\$ 5.50$ a day (for upper-middle-income countries). In order to ensure the comparability, coverage and quality of the poverty measurement data, we use the international poverty line at $\$ 5.50$ a day (see table 7.1 ). This higher-valued poverty threshold not only covers most underdeveloped countries but also includes many upper-middle-income

\footnotetext{
97 Scholars have argued that some aspects of well-being cannot be priced using a single dimension. Amartya See Sen. 1985. Commodities and Capabilities. Amsterdam: North-Holland.

98 Alkire et al. (2014).

99 Individual countries' international commitment to reduce global poverty in other poor countries and regions is assessed by "humanitarian aid" in our project.

100 For related discussions, see Ferreira, Francisco H. G., and María Ana Lugo. 2013. "Multidimensional Poverty Analysis: Looking for a Middle Ground.” World Bank Research Observer 28 (2): 220-35.

101 The R package povcalnetR provides an API for the data retrieving.
} 
countries and high-income economies, which is more relevant to current economic condition and makes the global comparisons possible.

However, the World Bank data suffer severe problems of missing values, with data appearing in certain years and missing in other years. Technical approaches can be applied to address some of the data shortcomings. More specifically, we use trends in GDP or national poverty statistics to impute missing poverty estimates by the World Bank. ${ }^{102}$ In order to construct the sub-index, we calculate the ranking score by assessing poverty governance in two dimensions: (1) contribution, which is measured by poverty rate reduction, referring to the extent to which a country's effort in reducing poverty in a given year has improved compared with the year before; (2) performance, which is measured by poverty gap, representing the achievement a country has made in poverty reduction (see Table 16). The data sources currently available limited our ability to rank all nation-states, but we did our best to cover as many countries as possible.

\subsubsection{Results}

Following the index construction processes and methods developed by this project (see the methodological section), this sub-index ranks 154 countries from 2010 to 2018 according to their level of performance in and contribution to global justice in the issue area of anti-poverty (see Table 17).

The second decade of the twenty-first century has witnessed great progress in reducing global poverty, with an unprecedented number of people around the world being lifted above basic needs. According to the World Bank, in 2010, about 54\% of the world population was living on less than US\$5.50 a day. By 2018, this figure had fallen to approximately $43 \%$, compared with roughly $24 \%$ and slightly less than $10 \%$, respectively, living below the US\$3.20 and US\$1.90 poverty lines. Meanwhile, the poverty gap at US\$5.50 a day, which reflects the intensity of poverty in a nation, decreased from 0.27 in 2010 to estimated 0.19 in 2018 . However, millions of individuals are still trapped in poverty and suffer from life challenges, not only in lowincome countries but also in middle-income and even high-income countries.

Despite having reduced considerably, progress in poverty alleviation has been very uneven. The countries in East Asia (especially China) experienced the largest reductions in the proportion of people living on less than US\$5.50 a day (Fig. 14). However, in comparison, more than two-thirds of the population in Africa are still living below the same threshold. Moreover, although steady progress has been made

\footnotetext{
102 If there are survey years before and after the missing year, we impute the missing year with linear splines. Suppose $l$ is an income/consumption level. $y_{1}$ and $y_{2}$ are survey years, and $y$ is our interested missing year, where $y_{1}<y<y_{2}$. Denote $p(l, y)$ as the proportion of people whose income/consumption is less than $l$ in the year $y$. Then our imputation is $p(l, y)=\frac{y-y_{1}}{y_{2}-y_{1}} p\left(l, y_{1}\right)+\frac{y_{2}-y}{y_{2}-y_{1}} p\left(l, y_{2}\right)$. If we only have the survey years on the one side of the missing year, we use GDP as an auxiliary information in the imputation. To be specific, people's income/consumption is assumed to be linear in the GDP. Suppose that GDP rises by 5\%. By our assumption, all people's income/consumption increase 5\%. In this scenario, the whole income/consumption distribution curve shrifts. We impute missing values by calculating poverty statistics from the new distribution.
} 
Table 16 Data on anti-poverty

\begin{tabular}{|c|c|c|c|}
\hline Category & Indicator & Data source & Coverage \\
\hline Contribution & $\begin{array}{l}\text { Poverty rate reduction } \\
\text { ( } \$ 5.5 \text {, population weighted) }\end{array}$ & World Bank & $\begin{array}{l}154 \text { countries } \\
\text { (145 countries have no } \\
\text { missing values; } 9 \text { coun- } \\
\text { tries have } 1 \sim 4 \text { missing } \\
\text { values) }\end{array}$ \\
\hline Performance & Poverty gap (\$5.5) & World Bank & $\begin{array}{l}154 \text { countries } \\
\text { (145 countries have no } \\
\text { missing values; } 9 \text { coun- } \\
\text { tries have } 1 \sim 4 \text { missing } \\
\text { values) }\end{array}$ \\
\hline
\end{tabular}

towards the US\$5.50 a day threshold, a slower pace in poverty reduction at this higher line is observed compared to the thresholds of US\$1.90 a day and US\$3.20 a day. ${ }^{103}$ This illustrates that as the world has grown richer, fighting extreme poverty is not sufficient for people to live a life free of poverty, and the task of poverty alleviation becomes even more difficult if we set the goals higher. In addition, the year 2018 brought some new challenges to global poverty governance, including the conflicts and violence in Syria, Afghanistan, Yemen, Democratic Republic of the Congo and the Central African Republic, economic crises in Venezuela and some Southern European countries, as well as rising sea levels and temperatures caused by the changing climate all constitute main drivers of the slow-down in global poverty reduction. Therefore, as we celebrate remarkable successes in lifting millions of people out of poverty, we must realize that more challenges lie before us and some of these challenges may even lead to a reversal of poverty reduction.

According to the anti-poverty index constructed in this project (seetable 7.2), China is leading the world in promoting global justice in the issue area of poverty alleviation, a position it has maintained since 2011. The poverty headcount rate at US\$5.50 a day in China dramatically dropped from $53.4 \%$ to $18.9 \%$, with the poverty gap simultaneously falling from 1.67 to 0.771 . This may not be surprising given the fact that the rapid and continuous economic growth in China over the past decade has lifted millions out of poverty. More importantly, this tremendous progress is also attributed to the huge investment and efforts made by the Chinese government in poverty eradication. Over the past few years, the Chinese government's efforts against poverty have greatly intensified as the leadership of President $\mathrm{Xi}$ Jinping proposed an ambitious campaign of "targeted poverty alleviation", as one of four "tough battles", to eliminate absolute poverty and build a moderately prosperous society by the end of 2020. ${ }^{104}$ Based on China's national poverty threshold, the number of people living in absolute poverty nationwide has decreased from

\footnotetext{
103 World Bank (2020).

104 Zuo, Cai, Zeng Qingjie \& Wang Zhongyuan 2020, Farewell to Poverty: The Institutional Foundations of Poverty Reduction in China [Gaobie Pinkun: Jingzhun Fupin De Zhidu Mima], Shanghai: Fudan University Press.
} 
Table 17 Country ranking in anti-poverty aspect of promoting global justice

\begin{tabular}{|c|c|c|c|c|c|c|c|c|c|}
\hline Country Name & 2010 & 2011 & 2012 & 2013 & 2014 & 2015 & 2016 & 2017 & 2018 \\
\hline China & 33 & 1 & 1 & 1 & 1 & 1 & 1 & 1 & 1 \\
\hline Iceland & 2 & 13 & 10 & 11 & 9 & 2 & 2 & 2 & 2 \\
\hline Switzerland & 5 & 2 & 3 & 2 & 3 & 3 & 3 & 3 & 3 \\
\hline Azerbaijan & 1 & 4 & 4 & 3 & 4 & 4 & 4 & 4 & 4 \\
\hline Cyprus & 11 & 8 & 2 & 7 & 6 & 13 & 6 & 5 & 5 \\
\hline Slovenia & 16 & 12 & 15 & 17 & 14 & 14 & 10 & 7 & 6 \\
\hline Norway & 3 & 6 & 7 & 6 & 7 & 5 & 5 & 6 & 7 \\
\hline Belgium & 17 & 14 & 16 & 14 & 8 & 7 & 7 & 8 & 8 \\
\hline France & 7 & 9 & 9 & 12 & 12 & 6 & 8 & 9 & 9 \\
\hline Netherlands & 9 & 5 & 11 & 8 & 18 & 19 & 9 & 10 & 10 \\
\hline Czechia & 22 & 23 & 24 & 15 & 27 & 18 & 24 & 18 & 11 \\
\hline Austria & 8 & 19 & 18 & 5 & 20 & 12 & 12 & 12 & 12 \\
\hline Malta & 14 & 10 & 17 & 9 & 2 & 8 & 11 & 11 & 13 \\
\hline Luxembourg & 13 & 7 & 8 & 4 & 5 & 10 & 14 & 13 & 14 \\
\hline Finland & 10 & 3 & 12 & 10 & 11 & 9 & 13 & 14 & 15 \\
\hline Germany & 6 & 11 & 13 & 13 & 10 & 11 & 15 & 15 & 16 \\
\hline Denmark & 4 & 25 & 6 & 19 & 23 & 16 & 16 & 16 & 17 \\
\hline Ireland & 24 & 22 & 23 & 27 & 21 & 17 & 19 & 19 & 18 \\
\hline Australia & 15 & 17 & 14 & 16 & 15 & 15 & 17 & 17 & 19 \\
\hline Slovakia & 20 & 21 & 21 & 20 & 22 & 23 & 23 & 25 & 20 \\
\hline $\begin{array}{l}\text { United Kingdom of Great Britain } \\
\text { and Northern Ireland }\end{array}$ & 23 & 15 & 5 & 18 & 13 & 25 & 18 & 20 & 21 \\
\hline Croatia & 19 & 20 & 22 & 21 & 24 & 22 & 21 & 21 & 22 \\
\hline Canada & 12 & 18 & 19 & 24 & 17 & 21 & 22 & 22 & 23 \\
\hline Sweden & 21 & 16 & 20 & 23 & 19 & 20 & 20 & 23 & 24 \\
\hline Belarus & 32 & 32 & 28 & 25 & 16 & 27 & 26 & 27 & 25 \\
\hline United States of America & 26 & 27 & 27 & 28 & 28 & 28 & 28 & 24 & 26 \\
\hline Japan & 18 & 24 & 25 & 22 & 25 & 24 & 25 & 26 & 27 \\
\hline Republic of Korea & 25 & 26 & 26 & 26 & 26 & 26 & 27 & 28 & 28 \\
\hline Poland & 39 & 37 & 38 & 39 & 41 & 37 & 29 & 30 & 29 \\
\hline Italy & 29 & 28 & 30 & 29 & 29 & 29 & 30 & 29 & 30 \\
\hline Hungary & 35 & 33 & 33 & 35 & 33 & 32 & 33 & 31 & 31 \\
\hline Spain & 28 & 29 & 29 & 31 & 30 & 31 & 31 & 32 & 32 \\
\hline Malaysia & 45 & 43 & 41 & 34 & 35 & 34 & 34 & 34 & 33 \\
\hline Portugal & 30 & 31 & 36 & 36 & 34 & 30 & 32 & 33 & 34 \\
\hline Russian Federation & 31 & 30 & 31 & 30 & 31 & 35 & 35 & 35 & 35 \\
\hline Bosnia and Herzegovina & 34 & 34 & 34 & 37 & 36 & 36 & 37 & 36 & 36 \\
\hline Lithuania & 41 & 40 & 40 & 40 & 40 & 39 & 39 & 38 & 37 \\
\hline Latvia & 42 & 42 & 42 & 42 & 43 & 42 & 42 & 40 & 38 \\
\hline Montenegro & 37 & 41 & 44 & 51 & 42 & 40 & 38 & 37 & 39 \\
\hline Lebanon & NA & NA & NA & 32 & 32 & 33 & 36 & 39 & 40 \\
\hline Israel & 36 & 36 & 35 & 38 & 37 & 38 & 40 & 41 & 41 \\
\hline Uruguay & 43 & 38 & 39 & 41 & 39 & 41 & 41 & 42 & 42 \\
\hline
\end{tabular}


Table 17 (continued)

\begin{tabular}{|c|c|c|c|c|c|c|c|c|c|}
\hline Country Name & 2010 & 2011 & 2012 & 2013 & 2014 & 2015 & 2016 & 2017 & 2018 \\
\hline Thailand & 53 & 51 & 54 & 53 & 53 & 44 & 47 & 44 & 43 \\
\hline Bulgaria & 40 & 44 & 43 & 46 & 45 & 45 & 44 & 45 & 44 \\
\hline Greece & 27 & 35 & 37 & 44 & 44 & 43 & 43 & 43 & 45 \\
\hline Serbia & 49 & 52 & 53 & 54 & 51 & 47 & 49 & 47 & 46 \\
\hline Seychelles & 48 & 47 & 46 & 47 & 47 & 46 & 48 & 46 & 47 \\
\hline Ukraine & 38 & 39 & 32 & 33 & 38 & 52 & 46 & 48 & 48 \\
\hline Estonia & 47 & 49 & 48 & 50 & 48 & 48 & 50 & 49 & 49 \\
\hline Kazakhstan & 56 & 45 & 47 & 43 & 46 & 49 & 52 & 51 & 50 \\
\hline Iran (Islamic Republic of) & 44 & 46 & 45 & 45 & 55 & 53 & 45 & 50 & 51 \\
\hline Chile & 52 & 53 & 51 & 48 & 49 & 50 & 53 & 53 & 52 \\
\hline Turkey & 50 & 48 & 52 & 49 & 50 & 54 & 51 & 52 & 53 \\
\hline Costa Rica & 46 & 50 & 50 & 52 & 52 & 51 & 54 & 54 & 54 \\
\hline Mauritius & 57 & 57 & 57 & 58 & 58 & 57 & 57 & 55 & 55 \\
\hline Republic of North Macedonia & 51 & 55 & 56 & 56 & 57 & 55 & 56 & 57 & 56 \\
\hline Panama & 54 & 54 & 55 & 57 & 56 & 56 & 55 & 56 & 57 \\
\hline Republic of Moldova & 70 & 66 & 67 & 61 & 62 & 58 & 59 & 58 & 58 \\
\hline Romania & 64 & 65 & 65 & 69 & 65 & 63 & 60 & 59 & 59 \\
\hline Dominican Republic & 68 & 69 & 72 & 73 & 69 & 64 & 62 & 62 & 60 \\
\hline Paraguay & 62 & 61 & 58 & 59 & 59 & 59 & 58 & 61 & 61 \\
\hline Brazil & 55 & 56 & 49 & 55 & 54 & 60 & 63 & 60 & 63 \\
\hline Bolivia (Plurinational State of) & 60 & 59 & 59 & 60 & 61 & 61 & 61 & 64 & 64 \\
\hline Viet Nam & 73 & 89 & 80 & 81 & 78 & 74 & 70 & 67 & 65 \\
\hline Peru & 61 & 62 & 60 & 62 & 64 & 62 & 65 & 65 & 66 \\
\hline Ecuador & 66 & 64 & 64 & 67 & 63 & 65 & 64 & 66 & 67 \\
\hline Tonga & 67 & 67 & 68 & 72 & 72 & 69 & 67 & 68 & 68 \\
\hline Tunisia & 72 & 70 & 69 & 71 & 70 & 71 & 71 & 71 & 69 \\
\hline Colombia & 69 & 68 & 70 & 70 & 68 & 68 & 69 & 70 & 70 \\
\hline Palestinian Territories & 59 & 60 & 62 & 64 & 66 & 67 & 68 & 69 & 71 \\
\hline Jordan & 58 & 58 & 61 & 65 & 67 & 70 & 72 & 72 & 72 \\
\hline Mongolia & 83 & 74 & 66 & 63 & 60 & 72 & 80 & 77 & 73 \\
\hline Morocco & 86 & 76 & 77 & 78 & 76 & 76 & 78 & 73 & 74 \\
\hline El Salvador & 76 & 81 & 78 & 77 & 79 & 78 & 74 & 74 & 75 \\
\hline Albania & 89 & 90 & 93 & 95 & 87 & 85 & 83 & 79 & 76 \\
\hline Jamaica & 71 & 71 & 73 & 74 & 75 & 77 & 75 & 76 & 77 \\
\hline Algeria & & & & 75 & 74 & 75 & 73 & 75 & 78 \\
\hline Gabon & 91 & 86 & 81 & 82 & 81 & 81 & 79 & 78 & 79 \\
\hline Mexico & 74 & 73 & 75 & 84 & 93 & 80 & 77 & 81 & 80 \\
\hline Central African Republic & 88 & 88 & 92 & 76 & 77 & 79 & 81 & 82 & 81 \\
\hline Tuvalu & NA & 93 & 97 & 98 & 98 & 86 & 87 & 85 & 82 \\
\hline Burundi & 82 & 83 & 84 & 88 & 88 & 84 & 84 & 84 & 83 \\
\hline Madagascar & 75 & 75 & 76 & 79 & 80 & 82 & 82 & 83 & 84 \\
\hline India & 130 & 96 & 99 & 113 & 103 & 99 & 91 & 89 & 85 \\
\hline
\end{tabular}


Table 17 (continued)

\begin{tabular}{|c|c|c|c|c|c|c|c|c|c|}
\hline Country Name & 2010 & 2011 & 2012 & 2013 & 2014 & 2015 & 2016 & 2017 & 2018 \\
\hline Honduras & 78 & 79 & 90 & 92 & 90 & 94 & 86 & 86 & 86 \\
\hline Venezuela (Bolivarian Republic of) & 63 & 63 & 63 & 66 & 71 & 73 & 76 & 80 & 87 \\
\hline Samoa & 85 & 78 & 88 & 93 & 96 & 91 & 85 & 87 & 88 \\
\hline Bhutan & 98 & 97 & 94 & 96 & 95 & 93 & 92 & 90 & 89 \\
\hline Armenia & 141 & 140 & 132 & 131 & 115 & 110 & 101 & 95 & 90 \\
\hline Sri Lanka & 125 & 120 & 112 & 111 & 104 & 100 & 95 & 93 & 91 \\
\hline Democratic Republic of the Congo & 65 & 72 & 74 & 80 & 82 & 83 & 88 & 88 & 92 \\
\hline Georgia & 115 & 109 & 106 & 100 & 99 & 101 & 102 & 98 & 93 \\
\hline Botswana & 92 & 91 & 89 & 87 & 85 & 90 & 93 & 94 & 94 \\
\hline Malawi & 80 & 77 & 79 & 83 & 83 & 87 & 90 & 91 & 95 \\
\hline Namibia & 96 & 98 & 95 & 97 & 94 & 89 & 89 & 92 & 96 \\
\hline Guatemala & 77 & 82 & 85 & 91 & 97 & 95 & 96 & 97 & 97 \\
\hline Zambia & 79 & 80 & 82 & 85 & 86 & 88 & 94 & 96 & 98 \\
\hline South Africa & 90 & 92 & 91 & 94 & 92 & 96 & 99 & 99 & 99 \\
\hline Lesotho & 81 & 84 & 87 & 90 & 91 & 98 & 100 & 100 & 100 \\
\hline Fiji & 108 & 106 & 107 & 108 & 110 & 103 & 104 & 103 & 101 \\
\hline Mozambique & 87 & 85 & 86 & 89 & 89 & 97 & 98 & 101 & 102 \\
\hline Guinea-Bissau & 84 & 87 & 83 & 86 & 84 & 92 & 97 & 102 & 103 \\
\hline Maldives & 104 & 103 & 105 & 103 & 100 & 105 & 107 & 105 & 104 \\
\hline Cabo Verde & 97 & 100 & 98 & 101 & 105 & 104 & 105 & 106 & 105 \\
\hline Tajikistan & 131 & 132 & 131 & 128 & 116 & 116 & 113 & 107 & 106 \\
\hline Indonesia & 111 & 121 & 134 & 123 & 128 & 128 & 103 & 104 & 107 \\
\hline Ghana & 116 & 112 & 109 & 109 & 112 & 113 & 114 & 109 & 108 \\
\hline Comoros & 102 & 105 & 104 & 105 & 106 & 106 & 108 & 110 & 109 \\
\hline Eswatini & 100 & 101 & 102 & 104 & 107 & 108 & 110 & 111 & 110 \\
\hline Benin & 101 & 104 & 101 & 102 & 101 & 102 & 106 & 108 & 111 \\
\hline Cameroon & 117 & 114 & 110 & 110 & 111 & 109 & 111 & 112 & 112 \\
\hline Nigeria & 99 & 102 & 103 & 107 & 109 & 112 & 117 & 114 & 113 \\
\hline Philippines & 124 & 127 & 127 & 122 & 123 & 123 & 119 & 118 & 114 \\
\hline Congo & 109 & 110 & 108 & 112 & 113 & 114 & 118 & 116 & 115 \\
\hline Togo & 95 & 99 & 100 & 106 & 108 & 111 & 116 & 117 & 116 \\
\hline Nicaragua & 123 & 125 & 118 & 116 & 114 & 115 & 115 & 113 & 117 \\
\hline Yemen & 143 & 144 & 145 & 148 & 144 & 141 & 132 & 122 & 118 \\
\hline Rwanda & 93 & 94 & 96 & 99 & 102 & 107 & 112 & 115 & 119 \\
\hline Chad & 112 & 115 & 116 & 117 & 119 & 119 & 121 & 120 & 120 \\
\hline Uganda & 114 & 116 & 122 & 130 & 125 & 120 & 122 & 121 & 121 \\
\hline Zimbabwe & NA & NA & 119 & 121 & 121 & 121 & 123 & 123 & 122 \\
\hline Myanmar & NA & NA & NA & NA & NA & NA & 141 & 135 & 123 \\
\hline Angola & 120 & 124 & 121 & 120 & 120 & 122 & 125 & 124 & 124 \\
\hline Sudan & 135 & 131 & 117 & 124 & 124 & 117 & 120 & 119 & 125 \\
\hline Papua New Guinea & NA & 123 & 125 & 125 & 127 & 127 & 126 & 125 & 126 \\
\hline Sierra Leone & 110 & 113 & 128 & 138 & 138 & 118 & 124 & 127 & 127 \\
\hline
\end{tabular}


Table 17 (continued)

\begin{tabular}{|c|c|c|c|c|c|c|c|c|c|}
\hline Country Name & 2010 & 2011 & 2012 & 2013 & 2014 & 2015 & 2016 & 2017 & 2018 \\
\hline Liberia & 103 & 108 & 115 & 134 & 136 & 135 & 133 & 130 & 128 \\
\hline Kenya & 118 & 118 & 120 & 119 & 122 & 126 & 127 & 128 & 129 \\
\hline Micronesia (Federated States of) & 113 & 117 & 123 & 132 & 131 & 131 & 130 & 129 & 130 \\
\hline Mauritania & 122 & 126 & 126 & 129 & 126 & 132 & 135 & 132 & 131 \\
\hline Egypt & 145 & 148 & 149 & 153 & 149 & 144 & 143 & 142 & 132 \\
\hline Iraq & 132 & 135 & 133 & 126 & 135 & 138 & 109 & 126 & 133 \\
\hline Niger & 105 & 119 & 124 & 127 & 130 & 130 & 131 & 131 & 134 \\
\hline Cote d'Ivoire & 126 & 129 & 130 & 135 & 133 & 134 & 137 & 136 & 135 \\
\hline Mali & 119 & 122 & 114 & 114 & 117 & 125 & 129 & 133 & 136 \\
\hline United Republic of Tanzania & 106 & 107 & 111 & 115 & 118 & 124 & 128 & 134 & 137 \\
\hline Senegal & 127 & 128 & 129 & 133 & 132 & 133 & 136 & 138 & 138 \\
\hline Haiti & NA & NA & NA & 136 & 134 & 136 & 138 & 139 & 139 \\
\hline Kiribati & 139 & 143 & 141 & 141 & 143 & 139 & 140 & 140 & 140 \\
\hline Burkina Faso & 107 & 111 & 113 & 118 & 129 & 129 & 134 & 137 & 141 \\
\hline Ethiopia & 136 & 136 & 135 & 137 & 137 & 137 & 139 & 141 & 142 \\
\hline Vanuatu & & 137 & 139 & 140 & 139 & 140 & 142 & 143 & 143 \\
\hline Timor-Leste & 133 & 138 & 140 & 144 & 147 & 148 & 149 & 145 & 144 \\
\hline Solomon Islands & 128 & 133 & 137 & 143 & 140 & 142 & 144 & 144 & 145 \\
\hline Gambia & 129 & 134 & 136 & 139 & 141 & 145 & 145 & 146 & 146 \\
\hline Nepal & 140 & 146 & 147 & 150 & 150 & 150 & 151 & 148 & 147 \\
\hline Uzbekistan & 134 & 139 & 144 & 147 & 146 & 146 & 147 & 147 & 148 \\
\hline Guinea & 121 & 130 & 138 & 142 & 142 & 143 & 146 & 149 & 149 \\
\hline Lao People's Democratic Republic & 138 & 142 & 143 & 145 & 145 & 147 & 148 & 150 & 150 \\
\hline Pakistan & 146 & 149 & 150 & 152 & 153 & 152 & 152 & 153 & 151 \\
\hline Bangladesh & 144 & 145 & 146 & 149 & 151 & 151 & 153 & 152 & 152 \\
\hline Sao Tome and Principe & 137 & 141 & 142 & 146 & 148 & 149 & 150 & 151 & 153 \\
\hline Kyrgyzstan & 142 & 147 & 148 & 151 & 152 & 153 & 154 & 154 & 154 \\
\hline
\end{tabular}

98.99 million at the end of 2012 to 5.51 million at the end of 2019, with the poverty headcount being reduced by more than 10 million annually for seven consecutive years. UN Secretary-General António Guterres called China's success as "the greatest anti-poverty achievement in history". ${ }^{105}$ Although many obstacles remain ahead of China's efforts to attain its ambitious goal and maintain its sustainable success, the country has presented the world with a role model in a sense that the government takes up its responsibility to help impoverished people. In 2018, the Chinese government launched a "Global Poverty Reduction \& Inclusive Growth Platform"106 to promote the exchange of experience and knowledge sharing on poverty reduction

\footnotetext{
105 See https://www.un.org/press/en/2019/sgsm19779.doc.htm (Accessed December 20, 2020).

106 See http://south.iprcc.org.cn/\# (Accessed December 20, 2020).
} 

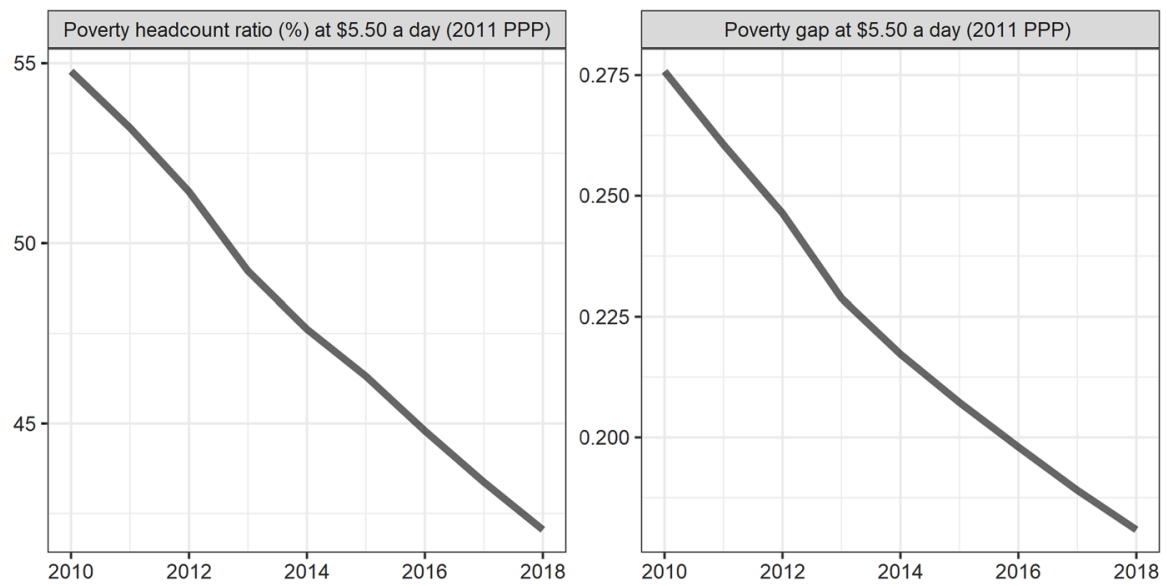

Fig. 14 The world's poverty headcount rate and poverty gap in 2010-2018

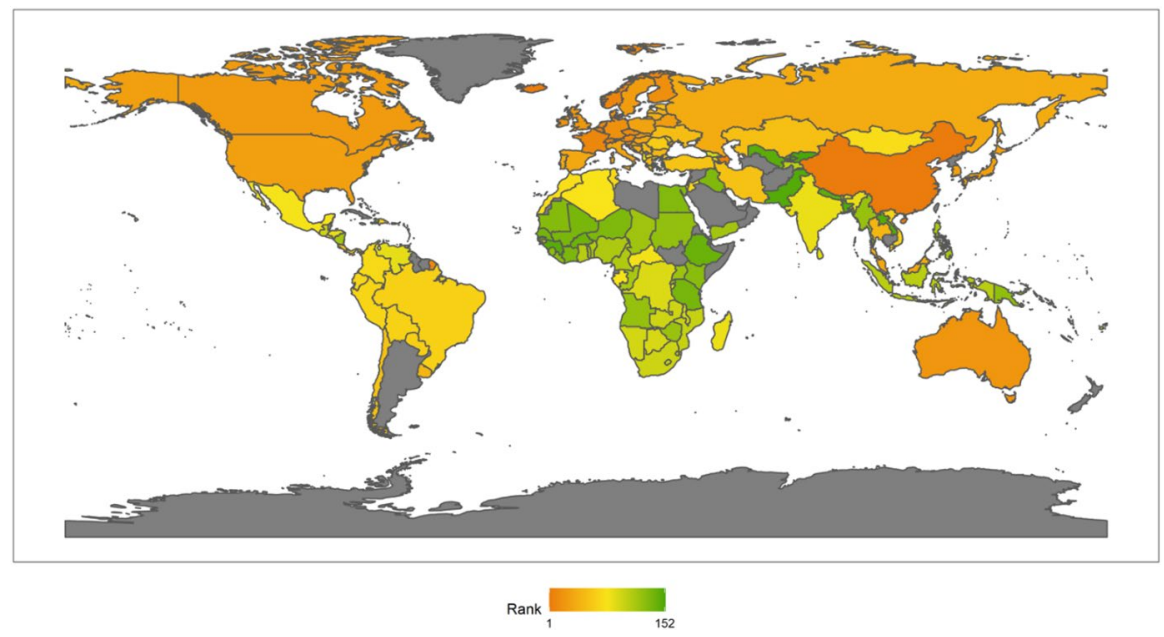

Fig. 152018 Index ranking of anti-poverty on a world map

with the rest of the world. European states and other OECD countries also have made great contributions to global justice in the domain of poverty reduction. This largely results from their relatively high income levels and stable economic development, as well as their income distribution policies and social welfare projects.

Among the ten countries ranked top in 2018 (see Fig. 15), three belong to Asia (including China, Azerbaijan, and Cyprus) and seven are in Europe (including Iceland, Switzerland, Slovenia, Norway, Belgium, France and the Netherlands). The above world map shows the ranking of all observed countries in 2018. Compared with the results for 2017 in our last annual report, the change is obvious. This is largely due to changes in the way the anti-poverty sub-index is constructed and 


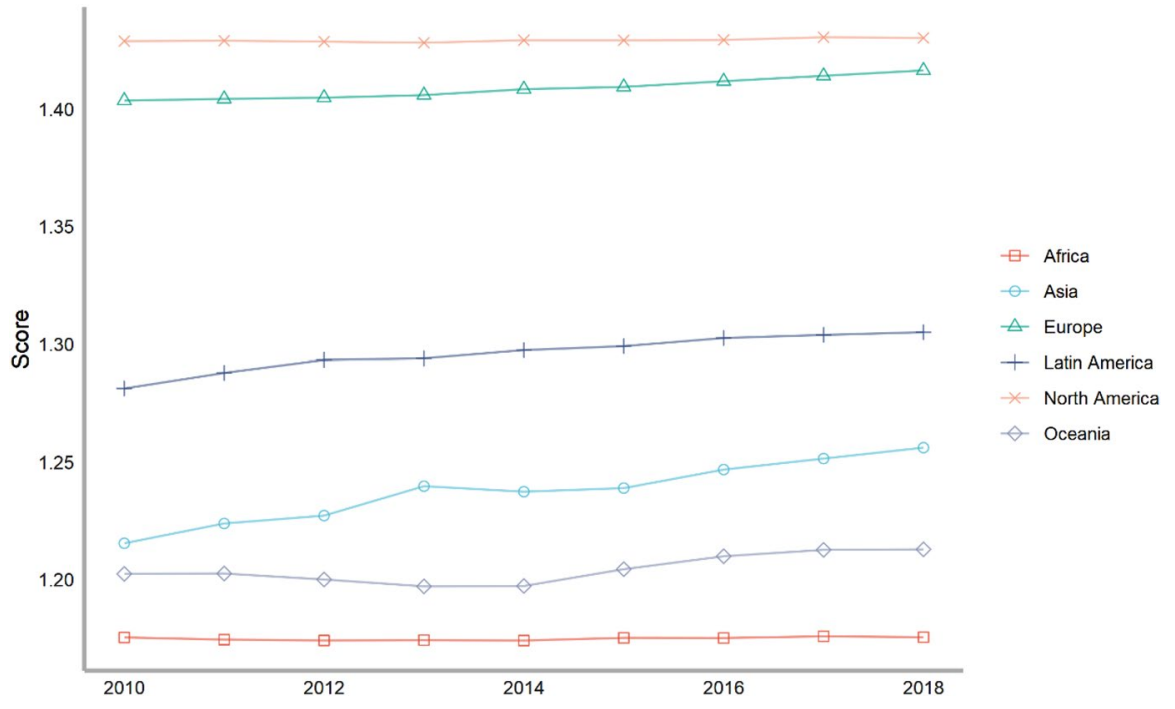

Fig. 16 The score of anti-poverty issue across continents, 2010-2018

measured. The 2018 index focuses only on absolute poverty and does not include the Gini coefficient, an indicator of relative poverty. In doing so, it is more reflective of the contribution and performance of individual countries in promoting global justice by addressing the basic needs of humankind. With the optimization of our index construction methods, it is normal for ranking fluctuations to occur between years.

Among the bottom-ranked are developing countries in Africa, Asia and the Pacific region. In these underdeveloped countries, more than half of the civilian population are living in conditions far below the international poverty threshold of the US\$5.50 a day. For example, in Kyrgyzstan, the poverty headcount rate has been higher than $64 \%$ and the poverty gap has stayed larger than 2.45 over the past 9 years. In Bangladesh, the poverty headcount rate reached a peak of $87.73 \%$ in 2010 and it has slowly decreased to $79.31 \%$ during the past decade. However, at the same time, the country's poverty gap increased from 2.45 to 2.52. A similar pattern was observed in Pakistan, Laos, and Sao Tome and Principe. Various pressing issues including rural underdevelopment, fast-growing population, economic and political uncertainty, lack of education and climate change pose barriers to poverty reduction in these countries.

\subsubsection{Regional Analysis}

As shown in Fig. 16, all of the six regions in the world have experienced slight improvements in poverty governance aspect of global justice in recent years. However, this progress has been regionally uneven. The geographic breakdown of regions with the ranking of anti-poverty aspect of promoting global justice ranging from best to worst include: North America, Europe, Latin America, Asia, Oceania and Africa. 
Asia Asia as whole has a relatively high poverty headcount ratio and poverty gap compared to other continents. However, the average Asian score has shown the largest improvement compared to other regions over the past decade, with its poverty headcount rate dropping dramatically from $64.68 \%$ to $45.22 \%$ and the poverty gap steadily falling from 0.310 to 0.173 , measured by the international poverty line of the US\$5.50 a day. This is because Asia has achieved a remarkable economic rise which has served to help hundreds of millions of Asians rise out of poverty. Furthermore, national governments like China, India, and Malaysia have invested heavily in implementing comprehensive anti-poverty policies, taking up their responsibilities to meet people's basic needs. At the sub-regional level, different sub-regions of Asia have performed quite unevenly in promoting global justice through poverty reduction. East Asia is the star performer, showing the strongest sub-regional score and the biggest decline in the poverty headcount ratio, and maintaining the lowest poverty gap in the region. It is not surprising that the leading contributor of East Asian poverty decline is China, whose fast economic growth and ambitious targeted poverty alleviation program have helped lift millions of people out of absolute poverty. The two more prosperous countries in East Asia, Japan and South Korea, have kept their poverty at a low level. Much of the progress has also been in Southeast Asia. Countries like Malaysia, Thailand, and Vietnam outperformed the world average. South Asia and the Central Asia have been relatively poor regions, but their poverty ratio and poverty gap have also been improving at a moderate rate over the past years. However, it must be noted that Asia is still far away from ending moderate poverty, given the reality that there are still over 1900 million Asians living below the US\$5.50 poverty line. Moreover, slowing economic growth, unresolved subregional instability, deepening rural-urban division and the devastating COVID-19 pandemic pose new challenges to the ongoing fight against poverty.

Europe Europe's average index score wins second place, closely following North America. European countries account for 15 of the top 20 countries in the 2018 ranking, with Iceland being the highest ranked country in the region and the second worldwide. During the observation years, the anti-poverty index score has recorded a slow and steady increase, driven by progress in reducing both the poverty headcount ratio and poverty gap on the continent. In 2018, Europe has reached its lowest ever poverty headcount ratio of $2.38 \%$ and lowest poverty gap of 0.00794 , measured by the international poverty line of US\$5.50 a day. In terms of sub-regional variations, Western Europe and Northern Europe maintained their leading performance in keeping the poverty headcount ratio and the poverty gap low. Eastern European countries are lagging behind but had the biggest improvements in the region in recent years, with the poverty headcount ratio decreasing from $6 \%$ to approximately $3 \%$ and the poverty gap from about 0.36 to 0.17 over the past decade. This was mainly due to steady economic growth in this sub-region following European integration. Southern Europe recorded a slight deterioration in the average index score, with rising poverty from 2010 to 2013 . This was largely attributed to the European debt crisis in which debt-laden countries such as Greece, Italy and Spain suffered heavily from stagnant economies and a high unemployment rate. As its economic situation became relatively more stabilized, both the poverty headcount ratio and the poverty gap in southern Europe started to fall from 2013. 
North America The North American region has maintained the world's highest average index score with little variation from 2010 to 2018 . The poverty headcount ratio below the international poverty line in North America has remained at around $1.6 \%$ and its poverty gap has been kept as low as roughly 0.011 . Within the region, Canada performed better than the United Studies, ranked 23rd versus 26th globally in 2018, thus contributing more to global justice in the domain of poverty governance.

Latin America Latin America, which includes 19 countries in this research, shows an overall moderate increase in the anti-poverty index score. Both the poverty headcount ratio and the poverty gap have experienced an obvious reduction in the region over the observation years, despite some temporary fluctuations in some countries. This progress was largely driven by the well-known poverty reduction strategy of Conditional Cash Transfers (CCTs) which has long been implemented in countries across the region. CCTs are an innovative poverty alleviation policy which is designed to support the poor by offering them cash payments upon conditions that the recipients participate in activities that develop human capital, such as school attendance, health-care checkups, and nutritional services. This policy helps to break the intergenerational transmission of poverty and will generate long-term positive effects on poverty eradication. Latin American countries including Chile, Mexico, Peru, Brazil, Colombia, Jamaica, Honduras and Nicaragua have used CCTs programs to fight poverty since the late 1990 s, ${ }^{107}$ and their effects have become increasingly apparent in the twenty-first century. Looking at the sub-regions, South America outperformed Central America and the Caribbean in contributing to global justice in terms of poverty governance. However, the pace of poverty reduction has obviously slowed in all the sub-regions in recent years. After years of sustained economic growth, some Latin American countries have fallen into an economic crisis, confronting growing unemployment rates and deteriorating welfare. An illustrative case is Venezuela. Although Venezuela used to be the strongest economy in Latin America (because it has the largest oil reserves in the world), the poverty rate and poverty gap have increased dramatically as a result of the economic collapse since the new president Nicolas Maduro came into office in 2013.

Africa Africa is the poorest continent and remains the bottom performer in promoting global justice in the domain of poverty governance. Although some African countries have made significant accomplishments in the fight against extreme poverty, the region as a whole recorded the highest poverty headcount ratio and poverty gap in the world. The past few years have witnessed the slowing pace of poverty reduction and a growing number of poor populations in Africa. Africa now accounts for most of the world's poor. The main drivers behind these major poverty challenges include the increasing number of violent conflicts, political unrest and terrorism events since 2010, the much slower economic growth rate, and the

\footnotetext{
107 For detailed discussions, see Michelle Adato and John Hoddinott eds. 2010. Conditional cash transfers in Latin America. Baltimore, MD: Johns Hopkins University Press; Maria Elisa Balen and Martin Fotta, 2019, Money from the Government in Latin America: Conditional Cash Transfer Programs and Rural Lives, London: Routledge.
} 
poor governance of fragile states. These factors render poverty more entrenched and harder to root out in Africa. Meanwhile the region's rapidly expanded population growth, ${ }^{108}$ especially in Sub-Saharan Africa, further makes the total number of people living in poverty continue to increase by millions each year. It is forecast that global poverty will become increasingly concentrated in Africa, ${ }^{109}$ which makes it even harder for the continent to escape poverty trap. Despite the region-wide trend, the status of poverty governance shows remarkable variations across different subregions in Africa. Not surprisingly, North Africa performs much better than its other African counterparts, and has displayed significant poverty reduction over the years studied. The average yearly number of people lifted from in Egypt and Morocco is 0.773 million and 0.399 million, respectively. By contrast, the poverty headcount ratio in the East, West and Central Africa has been higher than $85 \%$. Nigeria, the Democratic Republic of Congo, Tanzania, Ethiopia, Uganda and Kenya account for about half of the number of poor in Africa. West Africa has the highest poverty gap and continues to increase, with its average poverty gap reaching 0.490 in 2018 . These regional disparities are predicted to become even larger over time because of high population growth and continued armed conflicts in the East, West and Central Africa.

Oceania The poverty situation in Oceanian countries has not changed much over the years. Australia and New Zealand have been the two best performers in controlling poverty while the other countries (mostly island countries) lag far behind. Australia, the biggest country in Oceania, was ranked first in the region and 19th globally in 2018. As shown in Fig. 7.2, the Oceanian overall anti-poverty index score first recorded a very slight deterioration during 2010-2014 but then increased in 2014-2018. Oceania encompasses twelve other island nations with small populations. The Solomon Islands was ranked lowest in the region. Natural disasters, ethnic tensions, income disparities, rural underdevelopment and physical isolation from the international markets have exacerbated poverty in the country. ${ }^{110}$ As a result of climate change, some Oceanian countries like Tuvalu and Kiribati are starting to disappear under the rising sea. These environmental challenges render the people of these island countries at risk.

\subsubsection{Conclusion}

A world with global justice is a world free of poverty. As Mandela described, "it[poverty] is man-made, and it can be overcome and eradicated by the action of human beings. And overcoming poverty is not a gesture of charity. It is an act of justice." 111 For the past decade, absolute poverty has been steadily declining, which

\footnotetext{
108 See https://www.un.org/en/sections/issues-depth/population/index.html (Accessed December 25, 2020).

109 World Bank (2020).

110 See https://borgenproject.org/poverty-in-the-solomon-islands/ (Accessed December 24, 2020).

111 See https://www.theguardian.com/world/2005/feb/03/hearafrica05.development (Accessed December 26, 2020).
} 


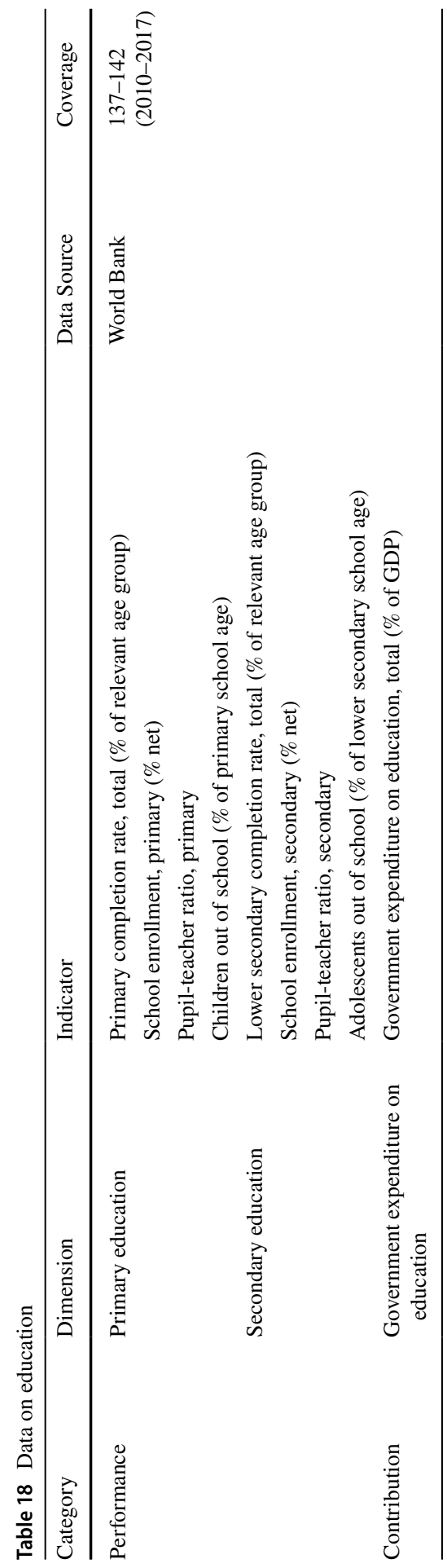


shows in the reduction of both the poverty headcount ratio and poverty gap in most parts of the world. However, still too many are trapped in extreme poverty and struggling for basic human needs. This reveals there is still much work to be done in the future. To further complicate this situation, economic crisis, armed conflict, and climate change are generating far-reaching implications for poverty reduction in the sense that they not only offset the previously achieved anti-poverty progress but also throw a growing number of people into poverty. Moreover, the disruption of the COVID-19 pandemic has brought about a new obstacle to global poverty governance, adding millions of new poor to the already-decelerated pace of poverty reduction. ${ }^{112}$ The decreases in the poverty ratio and poverty gap are projected to be the worst setbacks for a generation. All these factors make it increasingly challenging to maintain the momentum of progress and meet the global target under the 2030 Sustainable Development Agenda on poverty reduction.

This sub-index is mainly focused on a "thin" concept of poverty. If we take a broader view of poverty by considering additional non-monetary dimensions, the current situation could become even more alarming and worrying. The fight against poverty is not only about solving people's basic survival needs, but also working to provide people with more welfare and rights for human development. Viewed from this perspective, eradicating poverty in all its forms calls individual countries to develop a more comprehensive strategy, ranging from multidimensional anti-poverty policies to human capital building and to institutional reforms. In many places in the world, sovereign states cannot adequately address all these issues by acting alone. Concerted and collective efforts within a country or across countries are needed to further improve the effectiveness of poverty governance.

\subsection{Issue 8: Education}

\subsubsection{Introduction}

Education is not only a fundamental human right in itself but also an indispensable means of realizing other human rights, and thus is not only one of the elements of global justice but also an important tool for achieving global justice. Educational justice itself is an important factor embedded in the development of human society. On the one hand, more equitable education will build a more harmonious and civilized society by deepening people's awareness of public health, gender equality and political participation. On the other hand, educational inequality is closely related to the unbalanced distribution of power and wealth, and the intergenerational transmission of poverty caused by educational inequality will even aggravate the serious polarization of power and wealth, hinder social class mobility, and affect the progress of human society.

However, educational inequality in education is still one of the most significant challenges facing mankind in today's world. It is estimated that approximate 262

\footnotetext{
112 See https://www.worldbank.org/en/news/press-release/2020/10/07/covid-19-to-add-as-many-as-150million-extreme-poor-by-2021 (Accessed December 26, 2020).
} 
Table 19 Country ranking in education aspect of promoting global justice

\begin{tabular}{|c|c|c|c|c|c|c|c|c|c|}
\hline Country & 2010 & 2011 & 2012 & 2013 & 2014 & 2015 & 2016 & 2017 & 2018 \\
\hline Norway & 1 & 1 & 1 & 1 & 1 & 1 & 1 & 1 & 1 \\
\hline Iceland & 11 & 11 & 8 & 8 & 6 & 7 & 3 & 2 & 2 \\
\hline Denmark & 2 & 2 & 4 & 2 & 2 & 2 & 2 & 3 & 3 \\
\hline Switzerland & 3 & 3 & 5 & 4 & 5 & 3 & 5 & 5 & 4 \\
\hline United States of America & 5 & 6 & 6 & 6 & 7 & 6 & 6 & 6 & 5 \\
\hline Sweden & 4 & 4 & 2 & 3 & 4 & 5 & 4 & 4 & 6 \\
\hline Finland & 9 & 8 & 9 & 7 & 8 & 9 & 7 & 7 & 7 \\
\hline Netherlands & 7 & 7 & 11 & 9 & 10 & 11 & 8 & 8 & 8 \\
\hline Australia & 6 & 5 & 7 & 5 & 9 & 8 & 9 & 9 & 9 \\
\hline Belgium & 12 & 12 & 16 & 14 & 13 & 12 & 12 & 11 & 10 \\
\hline Ireland & 13 & 17 & 17 & 19 & 18 & 18 & 19 & 18 & 11 \\
\hline China & 16 & 16 & 10 & 11 & 11 & 14 & 13 & 12 & 12 \\
\hline Monaco & 20 & 15 & 14 & 18 & 22 & 21 & 10 & 13 & 13 \\
\hline New Zealand & 14 & 13 & 13 & 13 & 14 & 13 & 11 & 10 & 14 \\
\hline Austria & 15 & 14 & 18 & 15 & 17 & 16 & 14 & 14 & 15 \\
\hline Qatar & 8 & 10 & 15 & 10 & 16 & 17 & 20 & 23 & 16 \\
\hline Israel & 24 & 22 & 23 & 21 & 20 & 19 & 17 & 16 & 17 \\
\hline $\begin{array}{l}\text { United Kingdom of Great Britain } \\
\text { and Northern Ireland }\end{array}$ & 17 & 18 & 20 & 16 & 15 & 10 & 15 & 17 & 18 \\
\hline Syrian Arab Republic & 61 & 52 & 44 & 48 & 40 & 32 & 26 & 21 & 19 \\
\hline Canada & 10 & 9 & 12 & 12 & 12 & 15 & 16 & 15 & 20 \\
\hline Germany & 19 & 20 & 21 & 17 & 19 & 20 & 18 & 19 & 21 \\
\hline Japan & 18 & 19 & 19 & 20 & 21 & 22 & 21 & 20 & 22 \\
\hline Cyprus & 21 & 21 & 22 & 23 & 24 & 23 & 23 & 22 & 23 \\
\hline Andorra & 23 & 25 & 24 & 27 & 26 & 24 & 22 & 24 & 24 \\
\hline Malta & 27 & 24 & 28 & 22 & 23 & 27 & 25 & 25 & 25 \\
\hline Italy & 22 & 23 & 25 & 24 & 25 & 25 & 27 & 26 & 26 \\
\hline Spain & 25 & 26 & 27 & 26 & 28 & 28 & 30 & 28 & 27 \\
\hline Saudi Arabia & 30 & 28 & 26 & 25 & 27 & 26 & 28 & 27 & 28 \\
\hline Slovenia & 28 & 30 & 30 & 29 & 30 & 31 & 33 & 30 & 29 \\
\hline Portugal & 26 & 29 & 31 & 28 & 31 & 33 & 31 & 31 & 30 \\
\hline Estonia & 34 & 36 & 39 & 35 & 34 & 36 & 36 & 34 & 31 \\
\hline Czechia & 33 & 33 & 37 & 38 & 41 & 30 & 32 & 32 & 32 \\
\hline Cuba & 36 & 38 & 38 & 37 & 37 & 34 & 34 & 33 & 33 \\
\hline Barbados & 29 & 32 & 34 & 34 & 32 & 29 & 35 & 38 & 34 \\
\hline Brazil & 31 & 31 & 32 & 30 & 33 & 38 & 37 & 35 & 35 \\
\hline Latvia & 52 & 46 & 36 & 32 & 39 & 41 & 44 & 41 & 36 \\
\hline Uruguay & 48 & 37 & 35 & 31 & 35 & 35 & 38 & 36 & 37 \\
\hline Chile & 49 & 48 & 48 & 42 & 46 & 43 & 41 & 40 & 38 \\
\hline Poland & 37 & 40 & 41 & 40 & 42 & 45 & 42 & 42 & 39 \\
\hline Slovakia & 39 & 42 & 46 & 43 & 43 & 40 & 45 & 43 & 40 \\
\hline Hungary & 50 & 47 & 55 & 52 & 49 & 48 & 49 & 44 & 41 \\
\hline Lithuania & 41 & 41 & 45 & 44 & 45 & 46 & 51 & 46 & 42 \\
\hline
\end{tabular}


Table 19 (continued)

\begin{tabular}{|c|c|c|c|c|c|c|c|c|c|}
\hline Country & 2010 & 2011 & 2012 & 2013 & 2014 & 2015 & 2016 & 2017 & 2018 \\
\hline Argentina & 43 & 39 & 40 & 39 & 44 & 37 & 40 & 37 & 43 \\
\hline Costa Rica & 51 & 51 & 49 & 45 & 47 & 39 & 39 & 39 & 44 \\
\hline Panama & 69 & 74 & 67 & 56 & 58 & 52 & 43 & 52 & 45 \\
\hline Russian Federation & 35 & 34 & 33 & 33 & 36 & 44 & 48 & 45 & 46 \\
\hline Saint Kitts and Nevis & 46 & 50 & 50 & 47 & 48 & 55 & 54 & 49 & 47 \\
\hline Croatia & 45 & 49 & 54 & 50 & 53 & 53 & 55 & 50 & 48 \\
\hline Seychelles & 57 & 78 & 114 & 63 & 57 & 49 & 46 & 47 & 49 \\
\hline Lebanon & 47 & 56 & 53 & 51 & 54 & 56 & 50 & 55 & 50 \\
\hline Mexico & 44 & 44 & 43 & 41 & 38 & 42 & 47 & 48 & 51 \\
\hline Bahrain & 42 & 53 & 51 & 49 & 52 & 47 & 53 & 54 & 52 \\
\hline Thailand & 54 & 54 & 52 & 54 & 63 & 67 & 56 & 59 & 53 \\
\hline Malaysia & 53 & 45 & 47 & 46 & 51 & 51 & 57 & 57 & 54 \\
\hline Bulgaria & 56 & 55 & 56 & 53 & 55 & 58 & 62 & 60 & 55 \\
\hline Mauritius & 73 & 71 & 69 & 66 & 56 & 54 & 58 & 56 & 56 \\
\hline Romania & 63 & 66 & 71 & 71 & 67 & 71 & 70 & 71 & 57 \\
\hline Oman & 40 & 43 & 42 & 36 & 50 & 50 & 59 & 58 & 58 \\
\hline Guyana & 77 & 79 & 82 & 69 & 64 & 64 & 60 & 61 & 59 \\
\hline Kazakhstan & 70 & 59 & 60 & 60 & 66 & 62 & 65 & 63 & 60 \\
\hline Saint Vincent and the Grenadines & 67 & 80 & 103 & 67 & 72 & 63 & 63 & 62 & 61 \\
\hline Saint Lucia & 66 & 67 & 68 & 64 & 62 & 59 & 52 & 53 & 62 \\
\hline South Africa & 55 & 57 & 58 & 58 & 61 & 60 & 61 & 66 & 63 \\
\hline Iran (Islamic Republic of) & 71 & 63 & 65 & 76 & 79 & 82 & 73 & 70 & 64 \\
\hline Indonesia & 75 & 64 & 62 & 61 & 70 & 78 & 85 & 82 & 65 \\
\hline Colombia & 59 & 58 & 61 & 57 & 65 & 72 & 72 & 68 & 66 \\
\hline Kenya & 65 & 73 & 66 & 78 & 74 & 75 & 68 & 75 & 67 \\
\hline Eswatini & 79 & 72 & 72 & 77 & 77 & 74 & 77 & 74 & 68 \\
\hline Belize & 74 & 75 & 70 & 74 & 75 & 68 & 66 & 64 & 69 \\
\hline Ukraine & 68 & 69 & 64 & 65 & 73 & 81 & 81 & 78 & 70 \\
\hline Ecuador & 80 & 76 & 73 & 68 & 68 & 66 & 67 & 67 & 71 \\
\hline Belarus & 62 & 62 & 59 & 59 & 60 & 70 & 74 & 72 & 72 \\
\hline Mongolia & 64 & 60 & 57 & 55 & 59 & 69 & 69 & 73 & 73 \\
\hline Peru & 82 & 83 & 77 & 70 & 69 & 61 & 71 & 69 & 74 \\
\hline Fiji & 89 & 90 & 84 & 87 & 84 & 79 & 79 & 80 & 75 \\
\hline Jamaica & 60 & 65 & 74 & 72 & 76 & 73 & 76 & 76 & 76 \\
\hline Serbia & 78 & 70 & 75 & 73 & 78 & 76 & 78 & 77 & 77 \\
\hline Vanuatu & 72 & 68 & 63 & 62 & 71 & 65 & 64 & 65 & 78 \\
\hline Bhutan & 96 & 93 & 88 & 85 & 81 & 80 & 83 & 79 & 79 \\
\hline Republic of Moldova & 85 & 81 & 78 & 79 & 82 & 83 & 90 & 81 & 80 \\
\hline Namibia & 58 & 77 & 76 & 81 & 86 & 84 & 87 & 85 & 81 \\
\hline Honduras & NA & NA & NA & 94 & 93 & 93 & NA & NA & 82 \\
\hline Cabo Verde & 84 & 92 & 83 & 83 & 85 & 85 & 89 & 86 & 83 \\
\hline Central African Republic & 94 & 99 & 92 & 99 & 105 & 103 & 92 & 93 & 84 \\
\hline
\end{tabular}


Table 19 (continued)

\begin{tabular}{|c|c|c|c|c|c|c|c|c|c|}
\hline Country & 2010 & 2011 & 2012 & 2013 & 2014 & 2015 & 2016 & 2017 & 2018 \\
\hline Georgia & 83 & 84 & 91 & 88 & 91 & 91 & 88 & 83 & 85 \\
\hline Malawi & 88 & 86 & 80 & 82 & 88 & 95 & 108 & 113 & 86 \\
\hline Comoros & 81 & 85 & 79 & 75 & 80 & 86 & 80 & 88 & 87 \\
\hline Paraguay & 109 & 98 & 95 & 108 & 109 & 109 & 107 & 106 & 88 \\
\hline Sri Lanka & 98 & 97 & 93 & 103 & 108 & 97 & 75 & 89 & 89 \\
\hline Cambodia & 115 & 113 & 107 & 116 & 113 & 115 & 100 & 118 & 90 \\
\hline Tunisia & 97 & 100 & 101 & 104 & 106 & 92 & 97 & 96 & 91 \\
\hline Albania & 90 & 88 & 85 & 84 & 87 & 88 & 86 & 87 & 92 \\
\hline El Salvador & 93 & 104 & 97 & 93 & 94 & 87 & 91 & 91 & 93 \\
\hline Djibouti & 99 & 118 & 109 & 110 & 111 & 99 & 98 & 97 & 94 \\
\hline Jordan & NA & NA & NA & NA & NA & NA & 84 & 95 & 95 \\
\hline Afghanistan & 86 & 91 & 81 & 100 & 90 & 106 & 93 & 92 & 96 \\
\hline Lesotho & 91 & 87 & 86 & 86 & 89 & 89 & 96 & 107 & 97 \\
\hline Kyrgyzstan & 92 & 95 & 90 & 89 & 95 & 98 & 99 & 99 & 98 \\
\hline Nepal & 124 & 125 & 121 & 120 & 124 & 119 & 115 & 115 & 99 \\
\hline Guatemala & 103 & 101 & 94 & 96 & 98 & 94 & 102 & 100 & 100 \\
\hline Madagascar & 100 & 105 & 105 & 106 & 107 & 108 & 94 & 105 & 101 \\
\hline Nicaragua & 101 & 102 & 96 & 97 & 96 & 96 & 101 & 98 & 102 \\
\hline Maldives & 132 & 129 & 128 & 129 & 132 & 118 & 117 & 112 & 103 \\
\hline Philippines & 107 & 109 & 104 & 102 & 92 & 90 & 95 & 94 & 104 \\
\hline Ghana & 87 & 89 & 89 & 91 & 100 & 101 & 104 & 104 & 105 \\
\hline Lao People's Democratic Republic & 106 & 108 & 100 & 98 & 99 & 104 & 105 & 103 & 106 \\
\hline Timor-Leste & 105 & 107 & 102 & 101 & 102 & 102 & 103 & 102 & 107 \\
\hline Cameroon & 113 & 114 & 106 & 111 & 112 & 112 & 116 & 110 & 108 \\
\hline Armenia & 102 & 94 & 87 & 95 & 101 & 107 & 106 & 101 & 109 \\
\hline Mauritania & 114 & 82 & 98 & 90 & 104 & 105 & 109 & 108 & 110 \\
\hline Sierra Leone & 108 & 111 & 110 & 107 & 118 & 111 & 110 & 109 & 111 \\
\hline Tajikistan & 120 & 122 & 120 & 121 & 123 & 117 & 119 & 121 & 112 \\
\hline Azerbaijan & 104 & 103 & 99 & 105 & 103 & 110 & 118 & 116 & 113 \\
\hline Togo & 112 & 110 & 108 & 109 & 110 & 113 & 120 & 119 & 114 \\
\hline Cote d'Ivoire & 121 & 121 & 118 & 123 & 115 & 121 & 113 & 111 & 115 \\
\hline Rwanda & 127 & 106 & 117 & 112 & 121 & 116 & 114 & 117 & 116 \\
\hline Burundi & 110 & 117 & 115 & 115 & 116 & 114 & 112 & 114 & 117 \\
\hline Mozambique & 119 & 119 & 116 & 118 & 122 & 126 & 123 & 125 & 118 \\
\hline Benin & 123 & 123 & 123 & 119 & 125 & 123 & 121 & 122 & 119 \\
\hline Senegal & 126 & 124 & 124 & 122 & 126 & 124 & 125 & 126 & 120 \\
\hline Burkina Faso & 118 & 112 & 113 & 113 & 117 & 120 & 122 & 120 & 121 \\
\hline Niger & 122 & 120 & 119 & 124 & 120 & 125 & 126 & 132 & 122 \\
\hline Viet Nam & 125 & 130 & 129 & 131 & 131 & 128 & 130 & 128 & 123 \\
\hline Myanmar & NA & 96 & NA & NA & NA & NA & NA & 127 & 124 \\
\hline Mali & 116 & 115 & 112 & 114 & 114 & 122 & 124 & 124 & 125 \\
\hline Congo & 129 & 126 & 125 & 128 & 129 & 131 & 127 & 123 & 126 \\
\hline
\end{tabular}


Table 19 (continued)

\begin{tabular}{llllllllll}
\hline Country & 2010 & 2011 & 2012 & 2013 & 2014 & 2015 & 2016 & 2017 & 2018 \\
\hline Guinea & 117 & 116 & 111 & 117 & 119 & 127 & 129 & 130 & 127 \\
Chad & 131 & 128 & 126 & 126 & 128 & 129 & 131 & 133 & 128 \\
Sao Tome and Principe & 95 & 61 & 138 & 92 & 97 & 100 & 133 & 84 & 129 \\
United Republic of Tanzania & 128 & 127 & 122 & 127 & 130 & 132 & 132 & 129 & 130 \\
Liberia & NA & NA & 127 & 130 & 133 & NA & NA & 134 & 131 \\
Bangladesh & 133 & 131 & 130 & 132 & 134 & 133 & 134 & 135 & 132 \\
Gambia & 134 & 132 & 131 & 133 & 135 & 134 & 136 & 136 & 133 \\
Zambia & 135 & 133 & 132 & 134 & 137 & 135 & 135 & 137 & 134 \\
Uganda & 137 & 136 & 135 & 136 & 139 & 139 & 137 & 138 & 135 \\
Sudan & 138 & 135 & 134 & 138 & 140 & 136 & 139 & 139 & 136 \\
India & 140 & 137 & 137 & 135 & 136 & 137 & 138 & 140 & 137 \\
Ethiopia & 136 & 134 & 133 & 137 & 138 & 138 & 140 & 141 & 138 \\
Pakistan & 139 & 138 & 136 & 139 & 141 & 140 & 141 & 142 & 139 \\
San Marino & 32 & 35 & NA & NA & NA & NA & NA & 29 & NA \\
Grenada & NA & NA & NA & NA & NA & NA & NA & 51 & NA \\
Uzbekistan & NA & NA & NA & 80 & 83 & 77 & 82 & 90 & NA \\
Democratic Republic of the Congo & 130 & NA & NA & 125 & 127 & 130 & 128 & 131 & NA \\
Republic of Korea & NA & NA & NA & NA & NA & NA & 24 & NA & NA \\
Brunei Darussalam & 38 & 27 & 29 & NA & 29 & NA & 29 & NA & NA \\
Samoa & NA & NA & NA & NA & NA & NA & 111 & NA & NA \\
Luxembourg & NA & NA & 3 & NA & 3 & 4 & NA & NA & NA \\
Dominica & NA & NA & NA & NA & NA & 57 & NA & NA & NA \\
Angola & 76 & NA & NA & NA & NA & NA & NA & NA & NA \\
Solomon Islands & 111 & NA & NA & NA & NA & NA & NA & NA & NA \\
\hline & & & & & & & & & \\
\hline & & & & & & & & & \\
& & & & & & & & &
\end{tabular}

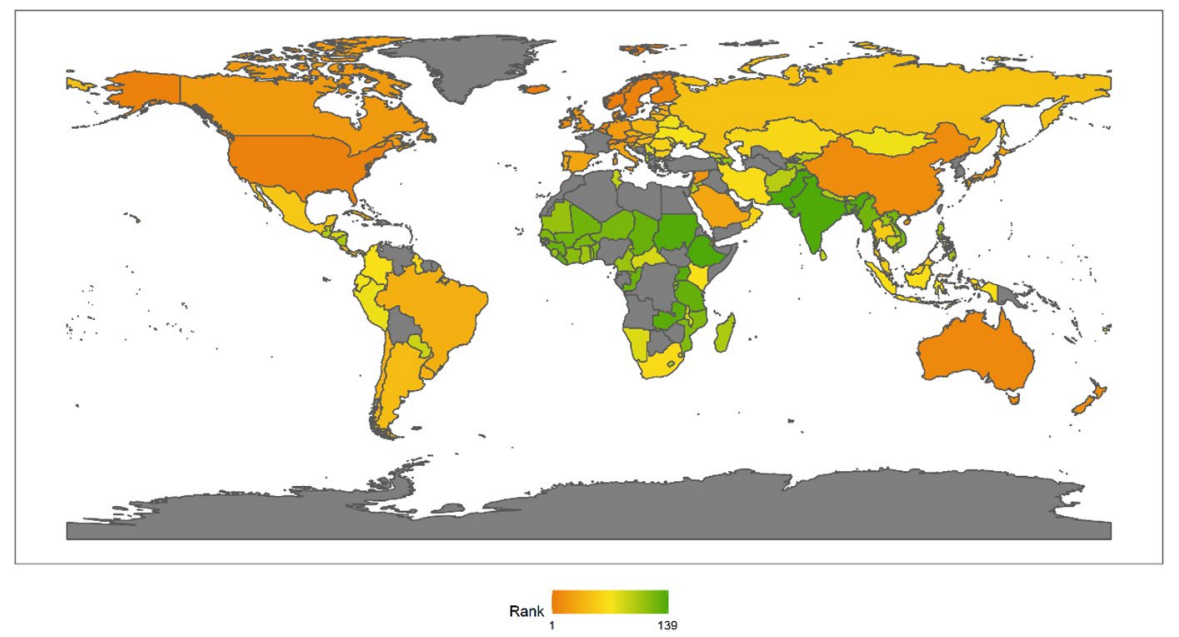

Fig. 172018 Index ranking of education on a world map 
million of the world's school-age population were out of school in 2017, at 64 million $(9 \%)$ for children of primary school age, 61 million for adolescents of lower secondary school age (16\%), and 138 million (36\%) for youth of upper secondary school age. ${ }^{113}$ The situation is particularly bad in low-income countries. Fewer than three out of four children began school on time in low-income countries in the period of 2000-2016. ${ }^{114}$

In this report, we focus on the role of states in protecting the citizens' right of access to basic education in terms of global justice. First, governments are "the primary duty bearers of the right to education". ${ }^{115}$ As protector of rights and provider of basic goods and services, states play a key role in protecting citizens' right to education and promoting equality in education by making rules for allocating educational resources and directly and indirectly investing education. Thus, the Convention on the Rights of the Child and the International Covenant on Economic, Social and Cultural Rights explicitly highlight states' obligations to realize the right to children's education, which is consistent with the principle of "cosmopolitan but duediligent responsibilities" (CDDR). ${ }^{116}$ Second, education as a human right usually refers to basic primary education. If children have obtained primary basic education, they will likely be literate and numerate, then will have the basic skills necessary to get a job in order to have a fulfilling life. ${ }^{117}$ Therefore, UNESCO's aim to construct a twenty-first-century learning society by promoting the Millennium Development Goal (MDG) to achieve universal primary public education for all by 2015 .

\subsubsection{Dimensions and Indicators}

We measure educational justice from two perspectives. The first is the performance of each country in education. As discussed earlier, from the perspective of global justice, we pay attention to the performance in basic education. We, therefore, use the primary education-related indicators to measure the performance of each country in primary education, as last year's report did. In many countries, lower secondary education is compulsory for school-age children. Therefore, incorporating lower secondary education into educational performance will enhance the effectiveness of the measurement. Specifically, we will use four indictors to measure the performance in both primary and secondary schools, namely, completion rate, school enrollment, pupil-teacher ratio and dropout rate. The second is the contribution of each country to education. We use the government education expenditures of each country to measure its efforts to promote its people's education. All educationrelated indexes come from the World Bank. ${ }^{118}$ The details are shown in Table 18.

\footnotetext{
113 United Nations Educational, Scientific and Cultural Organization (UNESCO). (2018). Global education monitoring report 2019: migration, displacement and education: building bridges, not walls.

114 United Nations Educational, Scientific and Cultural Organization (UNESCO). (2018). Global education monitoring report 2019: migration, displacement and education: building bridges, not walls.

115 Hutchings, (2017).

116 Guo et al. (2019).

117 Lee (2013).

118 See https://databank.worldbank.org/source/education-statistics-\%5e-all-indicators.
} 


\subsubsection{Results}

We improved our model of global justice this year, which enabled more countries to be included in the education rankings. Compared with the 2010-2017 ranking results in the 2019 report that only included 76-105 countries, this year's report includes 137-142 countries' ranking results ranging from 2010 to 2018, making our results have better representative.

Table 19 shows the ranking of countries in education issues from 2010 to 2018. Taking 2018 as an example, the top 10 countries of the ranking are Norway, Iceland, Denmark, Switzerland, the United States, Sweden, Finland, the Netherlands, Australia and Belgium, all of which are developed countries. And the bottom ten countries are Pakistan, Ethiopia, India, Sudan, Uganda, Zambia, Gambia, Bangladesh, Liberia and United Republic of Tanzania, all of which is underdeveloped countries. And Fig. 17 shows the distribution of the countries this issue covers and the ranking of education across countries in 2018.

\subsubsection{Regional Analysis}

Figure 18 shows the average score of each continent in the education issue area. The score clearly highly correlates to the level of economic development. First, as shown in Fig. 18, the score of North America, which is composed of the United States and Canada, in education is much better than that of the rest of the world. Second, Europe and Oceania also performed better; finally, Latin America, Asia and Africa performed poorly. In general, we found that all continents have been relatively stable in their education scores over the years.

However, it is worth noting that the rankings within continents vary greatly except in North America and Oceania. Generally speaking, North America, Western Europe, Australia and New Zealand and Northern Europe are in the first tier. And South Asia, West Africa, Central Asia, Central Africa, and North Africa rank low in the world.

Asia Similar to public health, the rank of Asia as a whole in the education issue area is only slightly higher than that of Africa, and within-continent variations exist. In Asia, for example, East Asia is second only to Northern Europe and does better than Southern and Eastern Europe. In particular, East Asia has an outstanding performance in the education performance dimension. For example, the scores of both China and Japan in the unweighted performance on education issue are among the best in the world, however, their scores in the contribution dimension are relatively low, which means that there is still a lot of room for improvement in their governments' financial investment in education. ${ }^{119}$

\footnotetext{
119 In order to distinguish between performance of education in global justice and educational performance itself, we further divided the performance dimension into population-weighted and unweighted performance. We use population-weighted performance, which is finally used for calculating global justice index, to measure the performance of a country in providing educational opportunities for a specific population relative to the world average and unweighted performance to measure the educational performance of a country, regardless of its population size.
} 


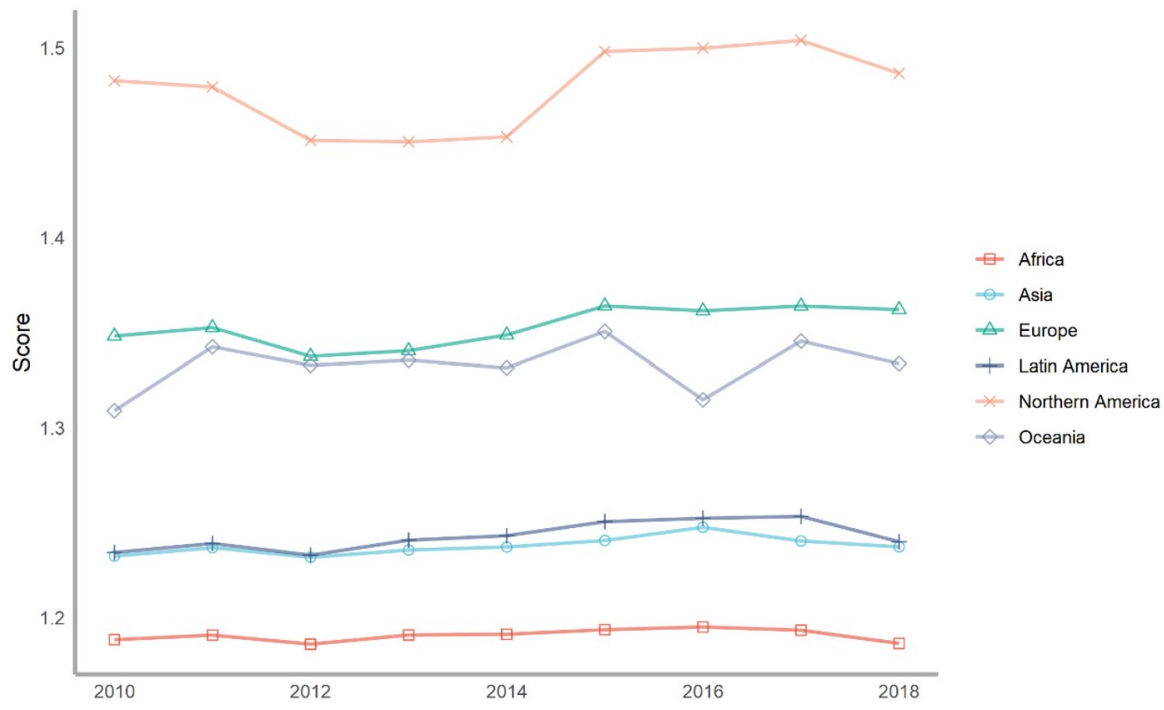

Fig. 18 The score in the education issue area across continents, 2010-2018

Thanks to improvement in our model, eight countries including Norway, Iceland, Denmark, Switzerland, the United States, the Netherlands, Australia and Belgium were included in this year's report. These eight countries are ahead of China in education issues. As a result, China's ranking dropped from third in 2017 (as elaborated in in2019's report) to 12th in 2018, as laid out in this year's report. Even so, we believe that China has already made very impressive achievements in education issues, especially in the performance dimension. It should be pointed out that the ranking of education issues refers to a country's contribution to global justice in basic education. The population-weighted performance, which is used to calculate global justice index, suggests that China ranks among the top in the world mainly due to two factors: the first is that China's performance on this issue exceeds the world average, meaning that the Chinese government provides its citizens with access to basic education that exceeds the world average. We compare China's unweighted performance to that of other top 14 countries in education issue and find that China still scores high on unweighted performance. ${ }^{120}$ In fact, China is close to full marks on some indicators in basic education. For example, in 2018, China's net enrollment rate of primary school and gross enrollment rate of lower secondary school reached $99.95 \%$, and $100.9 \%$, and the rate of trained teachers in primary and lower secondary school was $99.79 \%$ and $99.86 \%$, respectively. ${ }^{121}$ Besides, the

\footnotetext{
${ }^{120}$ In the issue of education, we only adopt four indicators of both primary and secondary education from the perspective of educational opportunity. Therefore, China's high score of unweighted performance does not mean that its basic education quality is comparable to that of the other top 14 countries, but simply means that China ranks high in the world in these four indicators.

${ }^{121}$ Ministry of Education of the People's Republic of China, The National Statistical Bulletin on Education Development in 2018, Stable URL: http://www.moe.gov.cn/jyb_sjzl/sjzl_fztjgb/201907/t20190724_ 392041.html.
} 
pupil-teacher ratio in both primary and lower secondary school has continued to decline since 2000. ${ }^{122}$ The second is China's huge population size. In other words, China has allowed a large population to have access to basic education beyond the world average. Therefore, China's good performance in education means that China has given a considerable proportion of the world's population access to basic education opportunities that are better than the world's average, but it does not mean that China has provided basic education opportunities for its citizens far beyond the rest of the world (including developed countries).

However, China's score in contribution dimension is much worse than that in performance dimension. Although both China's government expenditure on primary and lower secondary school and its share of GDP persistently increased, ${ }^{123}$ from the perspective of contribution, China's investment in basic education is much lower than the other 14 countries.

South and Central Asia do no better in education than most parts of Africa. In particular, South Asia's rank is at the bottom globally. It is also worth noting that the three populous countries in South Asia, Bangladesh, India and Pakistan, are better than most African countries in terms of unweighted performance in education, but still far below the world average. In the population-weighted model, we believe that because these countries provide with educational opportunities below the world average, they contribute to global justice relatively less in terms of the education issue area. $^{124}$

Europe Europe as a whole performed very well in education in 2018. Eight of the top 10 countries in the ranking of education issue come from Europe, namely Norway (1st), Iceland (2nd), Denmark (3rd), Switzerland (4th), Sweden (6th), Finland (7th), Netherlands (8th) and Belgium (10th). We compare the score (both unweighted and weighted) in the performance and contribution dimensions of the top 15 countries and find that there is only a small difference in the scores of performance dimension of the top countries except China, which suggests that these top countries perform well in the performance of education. The eight countries are all high-welfare countries. On the one hand, high investment improves their performance in basic education, therefore, increasing their scores in the (unweighted) performance dimension. Thanks to vast financial investment in basic education, on the other hand, the score of these countries in the contribution dimension are also very high.

North America North America as a whole is the best performer in the education issue area. First, it performs very well in the performance dimension. For example, out-of-school rates for children of primary school age and for adolescents of lower secondary school age in north America are $0.54 \%$ and $0.29 \%$ in 2018, respectively,

\footnotetext{
122 Yue et al. (2018).

123 Morgan et al. (2017).

124 The bottom top three countries in education are Pakistan, Ethiopia and India, all of which are far lower than other countries in the score in population-weighted performance dimension. In fact, the scores of India and Pakistan in unweighted performance ranked the 122th and the 161th of 178 countries in 2018. However, the two countries with large population make a considerable proportion of population in the world far behind the world average in terms of access to basic education.
} 
much lower than $1.6 \%$ for children of primary school age and $2.29 \%$ for adolescents of lower secondary school age of high-income countries in the same year. The pupil-teacher ratio in primary education in north America is 14 in 2018, on par with high-income countries and second only to Europe area at 13. Second, North America as a whole invests much in public education. Government expenditure on education in North America accounted for 5.0\% of GDP in 2014, on par with OECD countries and higher than $4.9 \%$ in Europe as a whole in 2017. Therefore, the United States of America and Canada, the two countries in North America, score highly in the dimension of both performance and contribution to education, high ranking 5 th and 20th in 2018, respectively.

Latin America The rank of Latin America as a whole is very similar to that of Asia, but higher than that of Africa in period of 2010-18. In the past 20 years, Latin America has made significant progress in basic education. First, the expenditure of governments on education has steadily increased in recent years. Expenditure as a share of GDP in Latin America increased from 3.9\% in 2000 to $5.6 \%$ in 2017-the highest of all continents - which is much higher than the global average $(4.5 \%)$ in 2017 . And expenditure as a share of total public expenditure in Latin America rose from $13.1 \%$ in 2002 to $16.5 \%$ in 2017 , the highest of all continents. ${ }^{125}$ Three countries from Latin America are among the top 10 countries worldwide in terms of spending the highest proportion of GDP on education, namely Montserrat (8.3\%), Belize (7.4\%) and Costa Rica (7.0\%). ${ }^{126}$ Second, the performance of public education also improved over the past 20 years, although the trend of improvement has slowed recently. Primary completion rate in Latin America as a whole slightly increased from $97.7 \%$ in 2000 to $98.15 \%$ in 2018 . And net school enrollment in primary education fluctuated at around 94\% from 2000-2018. Completion rates rose from 79 to $95 \%$ in primary school, from 59 to $81 \%$ in lower secondary school during this period. ${ }^{127}$ Meanwhile, the pupil-teacher ratio in Latin America decreased from 25.4 in 2000 to 21.3 in 2018.

It is also worth noting, however, that many social, cultural, economic and political factors, such as income inequality, social segregation, and colonial history are restricting the development of public education in Latin America.

Africa Africa as a whole has the lowest score in the education issue area in the world. In partciular, the unweighted performance of public education in sub-Saharan Africa was the worst in the world. In 2018, for instance, out-of-school rates were the highest in sub-Saharan Africa, at $19.2 \%$ of primary school age children and $37.1 \%$ of lower secondary school age adolescents. Out-of-school rates for children of primary school age and for adolescents of lower secondary school age in Southern Africa are $11 \%$ and $14.4 \%$ in 2018 , respectively, which are similar to $7.2 \%$ and $15.5 \%$ in South

\footnotetext{
125 UNESCO, 2020, Latin America and the Caribbean Report-Inclusion and Education: All Means All. See https://en.unesco.org/gem-report/LAC2020inclusion.

126 UNESCO, 2020, Latin America and the Caribbean Report-Inclusion and Education: All Means All. See https://en.unesco.org/gem-report/LAC2020inclusion.

127 UNESCO, 2020, Latin America and the Caribbean Report-Inclusion and Education: All Means All. See https://en.unesco.org/gem-report/LAC2020inclusion.
} 
Asia, a region which performs poorly based on our results. ${ }^{128}$ The gross enrolment ratio for primary and lower secondary education in sub-Saharan Africa in 2018 was only $73.6 \%$. This was followed by South Asia with an $82.4 \%$ ratio.

Due to low fiscal revenue and GDP, sub-Saharan does not perform as poorly in terms of government expenditure on education relative to its GDP and government expenditure. Government expenditure on education in sub-Saharan Africa accounted for $4.3 \%$ of GDP, higher than the 3.5\% in South Asia in 2017. And government expenditure on education accounted for $17.7 \%$ of government expenditure in 2018 , the highest of all regions in the world. ${ }^{129}$

Oceania Oceania as a whole performed worse than North America and Europe but better than Latin America, Asia and Africa in terms of education. Australia and New Zealand ranked 6th and 14th in 2018. The two countries perform well in both the performance and contribution dimensions. First, for example, total net enrolment rates of primary school and of lower secondary school in Australia are $99.6 \%$ and $97.5 \%$ in 2018, respectively. And out-of-school rates for children of primary school age and for lower secondary school age are $0.4 \%$ and $2.5 \%$ in the same year. Second, Australian government expenditure on education accounted for $5.16 \%$ of GDP in 2014, higher than the USA's $4.96 \%$ in 2014. According to our results, in fact, Australia and New Zealand as a whole performed worse than only North America and Western Europe, and better than the rest of the world.

\subsubsection{Conclusion}

Education is one of the fundamental elements of global justice. We use data from the World Bank to construct a country's score in education for global justice from the perspectives of both performance and contribution. Our analysis shows a positive relationship between the education scores and economic development: the higher GDP per capita, the higher the scores in the education issue area. Countries with large populations have a special responsibility for global justice. However, since most of countries with large populations are underdeveloped, they perform poorly in education. We use a weighted linear regression (WLR) to estimate the correlation between the score in the education area issue and GDP per capita by weighting population size, and then find that many countries with GDP per capita of less than 5000 US dollar are below the fitting line of the WIR in the figure, suggesting that these countries performance in the education issue area is worse than expected.

We further find a weak correlation between unweighted performance scores in the education issue area and GDP per capita, especially when GDP per capita is higher than 10,000 US dollars. This may be because we only focus on basic education.

\footnotetext{
128 Of all regions, sub-Saharan Africa has the highest rates of education exclusion. Over one-fifth of children between the ages of about 6 and 11 are out of school, followed by one-third of youth between the ages of about 12 and 14. According to UIS data, almost $60 \%$ of youth between the ages of about 15 and 17 are not in school. See UNESCO'S website: http://uis.unesco.org/en/topic/education-africa.

129 See UNESCO Institute for Statistics (http://uis.unesco.org).
} 
There is a ceiling effect of basic education in terms of global justice, that is, when the economy develops to a certain level, the continued development of the economy does not necessarily improve opportunities for basic education. ${ }^{130}$ However, we also find a strong positive correlation between unweighted performance scores in education issue and GDP per capita in the countries with a GDP per capita less than 10, 000 US dollars. Moreover, we find that many African countries are below the lowess line, suggesting that they perform worse than expected.

Finally, we also examine the relationship between the scores of contribution and unweighted performance in education issue, and find that when the score of contribution reaches a certain point, the continued increase in the score of contribution may not necessarily lead to an improvement in (unweighted) performance in basic primary education. However, a high correlation between the score of contribution and unweighted performance of countries with low-score of contribution in education issue is found. The higher score of contribution in education, the higher the score of unweighted performance, which means that the appropriate investment would improve the performance of basic education. It is worth noting that the ceiling effect of the contribution score in education may be a result of the way in which we focus on the opportunities rather than the quality of basic education. More specifically, we just focus on completion rate, school enrollment, pupil-teacher ratio and out-of-school rate in both primary and secondary education. However, measures of the quality of education, such as the literacy rate or educational inequality within countries, are not included in this report because of lack of systematic data cross all countries for the years the report covers. In fact, a great deal of evidence suggests that the quality of basic education in high-income countries is better than that in low-income countries. If the quality of basic education highly correlates with GDP per capita as well as the contribution score of basic education, fortunately this lack of measurement of basic education quality would not lead to a bias in the rankings in the education issue area of global justice.

\subsection{Issue 9: Public Health}

\subsubsection{Introduction}

The existence of health inequality in the world has become a consensus. ${ }^{131}$ For instance, there exist huge differences in life expectancy and mortality across

\footnotetext{
130 We only focus on the opportunities, rather than the qualities of basic education in terms of global justice since there is no systemic data to measure the qualities of basic education of all countries this report covers over years. Evidence suggests that the quality of learning outcomes, a proxy for the quality of basic education, highly correlates with GDP per capita (see Max Roser, Mohamed Nagdy and Esteban Ortiz-Ospina (2013), "Quality of Education”. Published online at OurWorldInData.org. Retrieved from: https://ourworldindata.org/quality-of-education [Online Resource]).

131 For example, Dwyer, J. (2005). Global health and justice. Bioethics, 19(5-6), 460-475. Ruger, J. P. (2009). Global health justice. Public Health Ethics, 2(3), 261-275. William W. Fisher and Talha Syed, Global Justice in Healthcare: Developing Drugs for the Developing World, 40 U.C. Davis L. Rev. 581 (2006), Available at: http://scholarship.law.berkeley.edu/facpubs/958.
} 
countries. In Japan, Switzerland, Spain, France and other high-income countries, life expectancy at birth is more than 80 years, while in Lesotho, Sierra Leone, the Central African Republic, Chad and other low-income countries, life expectancy at birth was less than 60 years in 2018. In Iceland, Finland, Norway, Japan, Singapore, and other high-income countries, the under-five mortality rate is less than three in 1000 in 2018. But in other countries, children die at high rate. For example, In Guinea, Sierra Leone, the Central African Republic, Chad, Somalia and Nigeria, more than 100 out of 1000 children will die before they are 5 years old according to the 2018 data. $^{132}$

Equitable access to comprehensive, effective health care systems is seen as a fundamental human right and a public good. ${ }^{133}$ A population in good health is essential for a prosperous economy and a stable society and can only be achieved through proper disease prevention and intervention. Providing adequate public health goods to the public is seen as an obligation of government. Therefore, the government is usually one of the main providers of public health goods and interveners in public health. ${ }^{134}$ We agree with Ruger (2009) that both the responsibility and the obligation of different actors, such as local, national and global actors, should be considered when constructing a theory of global health justice. ${ }^{135}$ Since the objectives of this report are evaluating the contribution of a country to global justice, however, we then focus on a country's efforts to provide equitable access to public health for its citizens rather than the role of global, national and local communities and institutions in global health justice. That is our main difference with Ruger (2018)'s provincial globalism which emphasizes that all local, national and global actors have responsibilities in reducing health inequalities. Without nations' efforts, global health actors, including the World Health Organization, the World Bank and other United Nations organizations, the vast numbers of foundations, NGOs and other actors, are unable to sufficiently resolve global health problems.

If public health is divided into domestic and global public health, domestic public health must account for the vast majority of national responsibility. ${ }^{136}$ Thus, in this report, we focus on the effort of a country to provide domestic public health to its citizens. The connections between public health as a domestic public good and public health as a country's contribution to the global public good is that when one country progresses in public health, it also improves the whole world's public

\footnotetext{
132 The statistics on life expectancy and the under-five mortality are drown from the website of the World Bank. See https://data.worldbank.org/.

133 For example, The International Covenant on Economic, Social and Cultural Rights (ICESCR) proclaims a universal human right to health, namely, the right of everyone to the enjoyment of the highest attainable standard of physical and mental health.

134 Although we believe that NGOs and international organization, such as World Health Organization will play an important role in providing global public health, they are still secondary providers of public health goods.

135 See Ruger (2009).

136 A theory of global health justice always considers public health as a global justice Ruger, J. P. (2009), and Ruger, J. P. (2009). it is difficult to distinguish the contribution of a country from the contribution of other actors, such as international organization and NGOs. Ruger (2009), Dwyer (2005).
} 


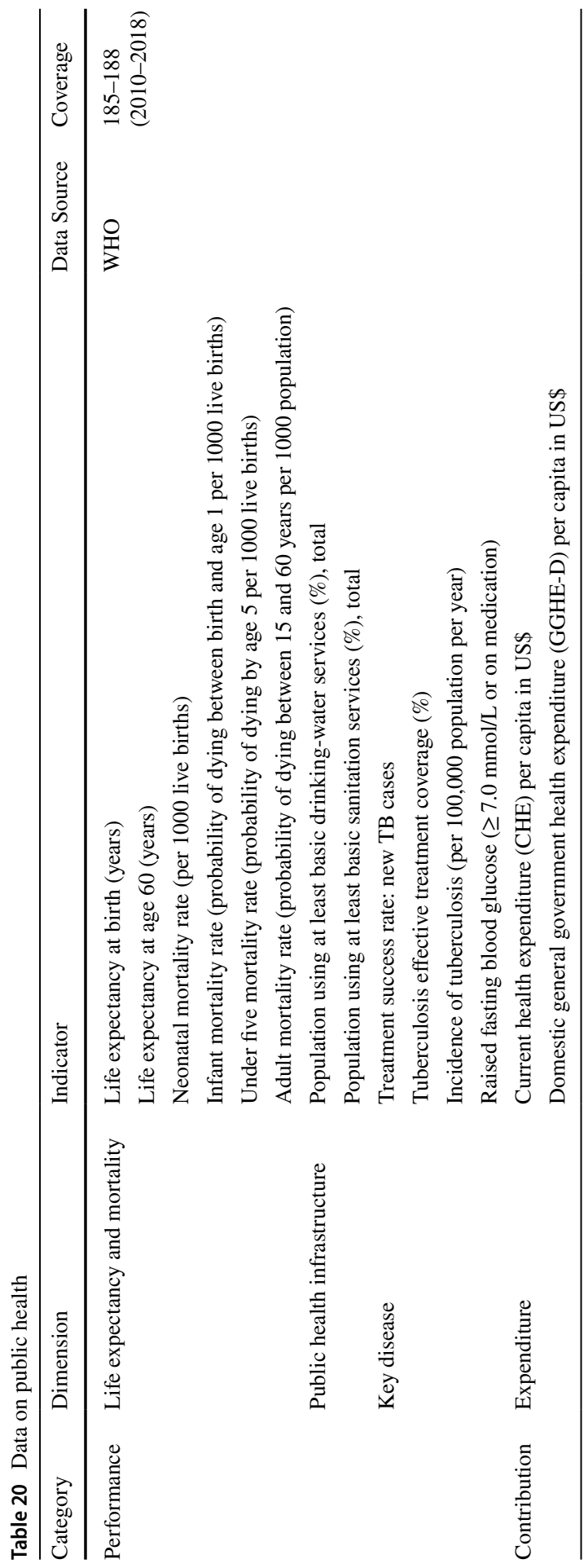


Table 21 Country ranking in the protection of public health

\begin{tabular}{|c|c|c|c|c|c|c|c|c|c|}
\hline Country & 2010 & 2011 & 2012 & 2013 & 2014 & 2015 & 2016 & 2017 & 2018 \\
\hline United States of America & 11 & 12 & 9 & 9 & 2 & 1 & 1 & 1 & 1 \\
\hline Norway & 1 & 1 & 1 & 1 & 1 & 2 & 2 & 2 & 2 \\
\hline Germany & 4 & 7 & 7 & 5 & 6 & 6 & 6 & 6 & 3 \\
\hline Iceland & 17 & 19 & 19 & 16 & 14 & 10 & 9 & 7 & 4 \\
\hline France & 5 & 6 & 6 & 6 & 7 & 8 & 8 & 9 & 5 \\
\hline Luxembourg & 2 & 2 & 2 & 3 & 3 & 3 & 3 & 3 & 6 \\
\hline Sweden & 10 & 3 & 4 & 2 & 4 & 4 & 4 & 4 & 7 \\
\hline Denmark & 3 & 5 & 5 & 4 & 5 & 5 & 5 & 5 & 8 \\
\hline Japan & 6 & 4 & 3 & 7 & 8 & 7 & 7 & 8 & 9 \\
\hline Belgium & 14 & 13 & 14 & 13 & 11 & 12 & 12 & 10 & 10 \\
\hline $\begin{array}{l}\text { United Kingdom of Great Britain } \\
\text { and Northern Ireland }\end{array}$ & 7 & 9 & 8 & 8 & 9 & 9 & 10 & 11 & 11 \\
\hline Ireland & 12 & 17 & 17 & 19 & 18 & 17 & 15 & 12 & 12 \\
\hline Australia & 19 & 16 & 16 & 18 & 20 & 18 & 16 & 15 & 13 \\
\hline Finland & 16 & 15 & 15 & 15 & 12 & 13 & 13 & 14 & 14 \\
\hline Netherlands & 8 & 10 & 10 & 10 & 10 & 11 & 11 & 13 & 15 \\
\hline Canada & 15 & 14 & 13 & 14 & 16 & 14 & 17 & 16 & 16 \\
\hline Austria & 18 & 18 & 18 & 17 & 17 & 15 & 14 & 18 & 17 \\
\hline New Zealand & 21 & 20 & 20 & 20 & 19 & 20 & 20 & 19 & 18 \\
\hline Italy & 9 & 11 & 12 & 12 & 15 & 16 & 18 & 17 & 19 \\
\hline Switzerland & 26 & 22 & 22 & 23 & 24 & 22 & 24 & 22 & 20 \\
\hline China & 34 & 27 & 23 & 22 & 21 & 19 & 19 & 20 & 21 \\
\hline Brunei Darussalam & 25 & 24 & 26 & 28 & 26 & 25 & 22 & 21 & 22 \\
\hline Nauru & 24 & 25 & 25 & 27 & 27 & 24 & 21 & 23 & 23 \\
\hline Kuwait & 33 & 30 & 28 & 32 & 29 & 30 & 34 & 25 & 24 \\
\hline Tuvalu & 22 & 21 & 21 & 24 & 23 & 23 & 23 & 24 & 25 \\
\hline Spain & 23 & 26 & 32 & 35 & 35 & 33 & 28 & 28 & 26 \\
\hline Cuba & 28 & 33 & 33 & 34 & 28 & 26 & 26 & 26 & 27 \\
\hline Qatar & 55 & 49 & 34 & 25 & 22 & 21 & 25 & 31 & 28 \\
\hline Czechia & 30 & 31 & 30 & 31 & 33 & 31 & 33 & 32 & 29 \\
\hline Oman & 41 & 40 & 39 & 37 & 32 & 28 & 32 & 30 & 30 \\
\hline Micronesia (Federated States of) & 29 & 29 & 27 & 30 & 31 & 27 & 29 & 27 & 31 \\
\hline Israel & 54 & 55 & 56 & 52 & 48 & 42 & 37 & 41 & 32 \\
\hline Kiribati & 27 & 28 & 29 & 29 & 30 & 29 & 30 & 29 & 33 \\
\hline Argentina & 73 & 64 & 50 & 45 & 41 & 34 & 49 & 40 & 34 \\
\hline Estonia & 46 & 46 & 47 & 48 & 46 & 44 & 45 & 42 & 35 \\
\hline Solomon Islands & 32 & 32 & 31 & 33 & 34 & 32 & 31 & 33 & 36 \\
\hline Botswana & 94 & 84 & 79 & 71 & 63 & 67 & 71 & 35 & 37 \\
\hline Croatia & 35 & 34 & 35 & 36 & 37 & 35 & 36 & 39 & 38 \\
\hline Papua New Guinea & 43 & 41 & 38 & 38 & 36 & 45 & 42 & 34 & 39 \\
\hline Vanuatu & 38 & 36 & 37 & 40 & 40 & 37 & 41 & 37 & 40 \\
\hline Slovakia & 50 & 48 & 52 & 46 & 38 & 36 & 35 & 43 & 41 \\
\hline Slovenia & 36 & 38 & 45 & 44 & 44 & 41 & 39 & 36 & 42 \\
\hline
\end{tabular}


Table 21 (continued)

\begin{tabular}{|c|c|c|c|c|c|c|c|c|c|}
\hline Country & 2010 & 2011 & 2012 & 2013 & 2014 & 2015 & 2016 & 2017 & 2018 \\
\hline Marshall Islands & 45 & 45 & 44 & 42 & 47 & 39 & 38 & 38 & 43 \\
\hline Costa Rica & 57 & 63 & 62 & 65 & 64 & 55 & 54 & 49 & 44 \\
\hline United Arab Emirates & 53 & 52 & 51 & 54 & 56 & 50 & 55 & 48 & 45 \\
\hline Sao Tome and Principe & 62 & 59 & 58 & 53 & 54 & 53 & 52 & 45 & 46 \\
\hline Uruguay & 86 & 83 & 74 & 67 & 62 & 58 & 58 & 56 & 47 \\
\hline Maldives & 109 & 129 & 119 & 115 & 91 & 60 & 59 & 57 & 48 \\
\hline Malta & 59 & 60 & 61 & 55 & 66 & 65 & 60 & 60 & 49 \\
\hline Samoa & 40 & 39 & 40 & 41 & 39 & 38 & 40 & 44 & 50 \\
\hline Lesotho & 65 & 53 & 53 & 56 & 51 & 49 & 56 & 50 & 51 \\
\hline Rwanda & 64 & 61 & 57 & 66 & 57 & 54 & 51 & 46 & 52 \\
\hline Timor-Leste & 39 & 35 & 36 & 39 & 43 & 40 & 43 & 47 & 53 \\
\hline Palau & 60 & 65 & 55 & 58 & 53 & 52 & 44 & 58 & 54 \\
\hline Portugal & 37 & 47 & 59 & 59 & 58 & 57 & 57 & 62 & 55 \\
\hline Andorra & 87 & 87 & 91 & 84 & 82 & 79 & 78 & 69 & 56 \\
\hline Romania & 44 & 56 & 54 & 49 & 49 & 51 & 53 & 55 & 57 \\
\hline Thailand & 52 & 42 & 49 & 47 & 50 & 47 & 48 & 54 & 58 \\
\hline Mozambique & 42 & 43 & 42 & 43 & 42 & 43 & 47 & 52 & 59 \\
\hline Poland & 56 & 57 & 64 & 63 & 61 & 62 & 66 & 59 & 60 \\
\hline Republic of Korea & 66 & 70 & 75 & 75 & 69 & 66 & 64 & 66 & 61 \\
\hline Bhutan & 49 & 51 & 60 & 62 & 65 & 59 & 63 & 53 & 62 \\
\hline Tonga & 48 & 54 & 43 & 57 & 45 & 46 & 46 & 51 & 63 \\
\hline Hungary & 67 & 68 & 80 & 77 & 75 & 70 & 69 & 63 & 64 \\
\hline Turkey & 47 & 44 & 46 & 50 & 52 & 48 & 50 & 61 & 65 \\
\hline Greece & 31 & 37 & 41 & 60 & 73 & 73 & 67 & 68 & 66 \\
\hline Seychelles & 82 & 72 & 65 & 64 & 72 & 68 & 61 & 64 & 67 \\
\hline Eswatini & 63 & 66 & 68 & 70 & 70 & 71 & 72 & 67 & 68 \\
\hline Malawi & 51 & 50 & 48 & 51 & 55 & 61 & 62 & 65 & 69 \\
\hline Colombia & 61 & 58 & 63 & 68 & 67 & 69 & 74 & 72 & 70 \\
\hline Zambia & 88 & 82 & 67 & 61 & 59 & 56 & 65 & 70 & 71 \\
\hline Bosnia and Herzegovina & 69 & 71 & 72 & 74 & 74 & 72 & 75 & 71 & 72 \\
\hline Saudi Arabia & 93 & 78 & 73 & 69 & 60 & 64 & 70 & 75 & 73 \\
\hline Djibouti & 79 & 67 & 66 & 72 & 68 & 63 & 68 & 73 & 74 \\
\hline Chile & 98 & 98 & 96 & 96 & 97 & 91 & 97 & 80 & 75 \\
\hline Lithuania & 58 & 62 & 76 & 81 & 76 & 75 & 79 & 77 & 76 \\
\hline Singapore & 138 & 137 & 129 & 117 & 110 & 94 & 93 & 92 & 77 \\
\hline Bolivia (Plurinational State of) & 100 & 100 & 103 & 101 & 93 & 80 & 83 & 81 & 78 \\
\hline Fiji & 77 & 94 & 93 & 100 & 95 & 90 & 90 & 78 & 79 \\
\hline Saint Vincent and the Grenadines & 91 & 97 & 77 & 82 & 86 & 84 & 91 & 76 & 80 \\
\hline Belarus & 75 & 91 & 84 & 94 & 94 & 98 & 77 & 79 & 81 \\
\hline Panama & 72 & 81 & 97 & 91 & 87 & 82 & 73 & 84 & 82 \\
\hline Dominica & 85 & 89 & 86 & 89 & 85 & 77 & 76 & 83 & 83 \\
\hline Belize & 74 & 79 & 83 & 83 & 83 & 76 & 81 & 85 & 84 \\
\hline
\end{tabular}


Table 21 (continued)

\begin{tabular}{|c|c|c|c|c|c|c|c|c|c|}
\hline Country & 2010 & 2011 & 2012 & 2013 & 2014 & 2015 & 2016 & 2017 & 2018 \\
\hline Peru & 124 & 126 & 117 & 111 & 101 & 97 & 100 & 86 & 85 \\
\hline Republic of North Macedonia & 101 & 95 & 95 & 88 & 92 & 87 & 96 & 87 & 86 \\
\hline Cabo Verde & 81 & 76 & 71 & 76 & 78 & 81 & 87 & 89 & 87 \\
\hline Zimbabwe & 131 & 146 & 144 & 135 & 108 & 115 & 107 & 90 & 88 \\
\hline Jamaica & 96 & 96 & 104 & 99 & 106 & 93 & 94 & 82 & 89 \\
\hline Suriname & 135 & 147 & 148 & 149 & 151 & 88 & 80 & 93 & 90 \\
\hline Algeria & 76 & 74 & 69 & 78 & 71 & 78 & 85 & 95 & 91 \\
\hline Gambia & 89 & 93 & 87 & 73 & 84 & 103 & 103 & 94 & 92 \\
\hline Bahrain & 84 & 86 & 81 & 80 & 79 & 74 & 86 & 102 & 93 \\
\hline United Republic of Tanzania & 105 & 102 & 94 & 90 & 90 & 95 & 82 & 91 & 94 \\
\hline Guyana & 107 & 111 & 110 & 109 & 111 & 114 & 89 & 88 & 95 \\
\hline Russian Federation & 78 & 75 & 70 & 79 & 77 & 83 & 92 & 99 & 96 \\
\hline Libya & 71 & 99 & 88 & 87 & 89 & 89 & 99 & 100 & 97 \\
\hline El Salvador & 97 & 88 & 99 & 86 & 88 & 85 & 88 & 101 & 98 \\
\hline Kazakhstan & 80 & 77 & 82 & 92 & 81 & 96 & 102 & 105 & 99 \\
\hline Mali & 155 & 150 & 136 & 103 & 105 & 102 & 108 & 103 & 100 \\
\hline Nicaragua & 119 & 107 & 105 & 106 & 103 & 101 & 95 & 96 & 101 \\
\hline Latvia & 95 & 85 & 98 & 97 & 98 & 99 & 104 & 107 & 102 \\
\hline Mongolia & 83 & 92 & 90 & 102 & 100 & 106 & 101 & 104 & 103 \\
\hline Trinidad and Tobago & 127 & 127 & 128 & 116 & 121 & 112 & 112 & 108 & 104 \\
\hline Madagascar & 125 & 104 & 114 & 126 & 102 & 92 & 84 & 97 & 105 \\
\hline Bahamas & 118 & 120 & 118 & 120 & 132 & 105 & 105 & 121 & 106 \\
\hline Ecuador & 143 & 140 & 133 & 131 & 123 & 130 & 119 & 109 & 107 \\
\hline Gabon & 92 & 101 & 101 & 95 & 107 & 107 & 98 & 106 & 108 \\
\hline Serbia & 90 & 90 & 92 & 98 & 104 & 104 & 106 & 110 & 109 \\
\hline South Africa & 128 & 124 & 120 & 127 & 125 & 122 & 123 & 113 & 110 \\
\hline Republic of Moldova & 113 & 125 & 111 & 114 & 109 & 126 & 130 & 111 & 111 \\
\hline Malaysia & 123 & 122 & 115 & 118 & 116 & 117 & 128 & 119 & 112 \\
\hline Tunisia & 115 & 110 & 108 & 105 & 112 & 111 & 113 & 112 & 113 \\
\hline Brazil & 121 & 123 & 127 & 122 & 119 & 124 & 127 & 120 & 114 \\
\hline Mexico & 129 & 121 & 116 & 113 & 113 & 110 & 111 & 118 & 115 \\
\hline Saint Kitts and Nevis & 147 & 154 & 149 & 138 & 135 & 137 & 117 & 114 & 116 \\
\hline Central African Republic & 134 & 131 & 125 & 139 & 118 & 86 & 122 & 98 & 117 \\
\hline Burkina Faso & 99 & 109 & 107 & 119 & 128 & 135 & 109 & 116 & 118 \\
\hline Namibia & 116 & 128 & 137 & 133 & 133 & 139 & 126 & 123 & 119 \\
\hline Bulgaria & 114 & 116 & 126 & 125 & 117 & 123 & 125 & 124 & 120 \\
\hline Jordan & 68 & 73 & 78 & 85 & 80 & 119 & 120 & 126 & 121 \\
\hline Lebanon & 148 & 142 & 124 & 130 & 124 & 121 & 121 & 115 & 122 \\
\hline Iran (Islamic Republic of) & 160 & 161 & 158 & 154 & 127 & 118 & 118 & 127 & 123 \\
\hline Barbados & 102 & 113 & 102 & 112 & 126 & 120 & 115 & 129 & 124 \\
\hline Kenya & 126 & 130 & 132 & 134 & 130 & 125 & 124 & 125 & 125 \\
\hline Uganda & 111 & 117 & 138 & 140 & 122 & 127 & 129 & 122 & 126 \\
\hline
\end{tabular}


Table 21 (continued)

\begin{tabular}{|c|c|c|c|c|c|c|c|c|c|}
\hline Country & 2010 & 2011 & 2012 & 2013 & 2014 & 2015 & 2016 & 2017 & 2018 \\
\hline Cyprus & 110 & 114 & 123 & 121 & 131 & 132 & 132 & 132 & 127 \\
\hline Burundi & 108 & 106 & 106 & 104 & 138 & 140 & 116 & 128 & 128 \\
\hline Dominican Republic & 142 & 138 & 139 & 137 & 136 & 133 & 142 & 131 & 129 \\
\hline Haiti & 103 & 80 & 89 & 110 & 99 & 108 & 110 & 130 & 130 \\
\hline Saint Lucia & 154 & 156 & 152 & 152 & 145 & 138 & 143 & 133 & 131 \\
\hline Viet Nam & 133 & 139 & 131 & 123 & 134 & 134 & 114 & 117 & 132 \\
\hline Antigua and Barbuda & 106 & 108 & 109 & 108 & 114 & 109 & 131 & 135 & 133 \\
\hline Congo & 122 & 115 & 85 & 93 & 96 & 100 & 134 & 139 & 134 \\
\hline Grenada & 139 & 144 & 150 & 151 & 140 & 145 & 137 & 141 & 135 \\
\hline Niger & 159 & 165 & 165 & 157 & 158 & 150 & 162 & 136 & 136 \\
\hline Honduras & 136 & 134 & 145 & 144 & 141 & 143 & 139 & 144 & 137 \\
\hline Uzbekistan & 132 & 133 & 130 & 128 & 120 & 129 & 141 & 140 & 138 \\
\hline Benin & 137 & 136 & 112 & 136 & 139 & 128 & 136 & 137 & 139 \\
\hline Paraguay & 140 & 135 & 141 & 146 & 137 & 136 & 138 & 138 & 140 \\
\hline Mauritius & 141 & 145 & 142 & 147 & 143 & 142 & 144 & 142 & 141 \\
\hline Ukraine & 120 & 132 & 121 & 132 & 147 & 148 & 146 & 143 & 142 \\
\hline Ghana & 112 & 112 & 122 & 124 & 142 & 113 & 140 & 147 & 143 \\
\hline Sri Lanka & 151 & 152 & 151 & 143 & 144 & 141 & 145 & 146 & 144 \\
\hline Kyrgyzstan & 117 & 119 & 113 & 129 & 152 & 146 & 150 & 151 & 145 \\
\hline Lao People's Democratic Republic & 158 & 149 & 143 & 141 & 146 & 131 & 135 & 134 & 146 \\
\hline Mauritania & 163 & 164 & 156 & 145 & 148 & 144 & 152 & 150 & 147 \\
\hline Liberia & 146 & 141 & 135 & 142 & 149 & 149 & 147 & 149 & 148 \\
\hline Indonesia & 176 & 177 & 171 & 167 & 165 & 159 & 149 & 145 & 149 \\
\hline Angola & 104 & 103 & 100 & 107 & 129 & 147 & 148 & 148 & 150 \\
\hline Eritrea & 144 & 105 & 146 & 148 & 150 & 153 & 153 & 157 & 151 \\
\hline Morocco & 156 & 155 & 153 & 150 & 155 & 155 & 151 & 152 & 152 \\
\hline Georgia & 173 & 185 & 181 & 172 & 168 & 158 & 156 & 156 & 153 \\
\hline Senegal & 153 & 157 & 161 & 165 & 153 & 154 & 154 & 160 & 154 \\
\hline Guatemala & 157 & 159 & 157 & 158 & 154 & 157 & 159 & 155 & 155 \\
\hline Democratic Republic of the Congo & 149 & 153 & 154 & 156 & 157 & 152 & 155 & 159 & 156 \\
\hline Tajikistan & 172 & 160 & 164 & 160 & 160 & 160 & 166 & 158 & 157 \\
\hline Iraq & 70 & 69 & 160 & 155 & 163 & 176 & 178 & 154 & 158 \\
\hline Cote d'Ivoire & 180 & 181 & 168 & 174 & 166 & 163 & 160 & 153 & 159 \\
\hline Ethiopia & 152 & 163 & 155 & 159 & 171 & 164 & 164 & 162 & 160 \\
\hline Cambodia & 165 & 176 & 159 & 162 & 156 & 156 & 158 & 161 & 161 \\
\hline Nepal & 167 & 171 & 169 & 171 & 169 & 166 & 167 & 163 & 162 \\
\hline Sierra Leone & 161 & 170 & 177 & 163 & 115 & 116 & 133 & 167 & 163 \\
\hline Philippines & 162 & 173 & 173 & 170 & 172 & 165 & 165 & 164 & 164 \\
\hline Chad & 174 & 166 & 166 & 166 & 161 & 161 & 163 & 165 & 165 \\
\hline Egypt & 171 & 169 & 176 & 175 & 173 & 171 & 168 & 166 & 166 \\
\hline Togo & 168 & 167 & 162 & 161 & 162 & 162 & 157 & 168 & 167 \\
\hline Equatorial Guinea & 170 & 162 & 134 & 178 & 179 & 178 & 174 & 171 & 168 \\
\hline
\end{tabular}


Table 21 (continued)

\begin{tabular}{llllllllll}
\hline Country & 2010 & 2011 & 2012 & 2013 & 2014 & 2015 & 2016 & 2017 & 2018 \\
\hline Guinea & 164 & 158 & 163 & 164 & 170 & 168 & 161 & 169 & 169 \\
Turkmenistan & 175 & 175 & 172 & 168 & 174 & 173 & 180 & 170 & 170 \\
Guinea-Bissau & 130 & 118 & 167 & 173 & 164 & 170 & 171 & 174 & 171 \\
Pakistan & 183 & 180 & 175 & 177 & 177 & 175 & 173 & 172 & 172 \\
Cameroon & 182 & 151 & 186 & 184 & 184 & 180 & 179 & 178 & 173 \\
Comoros & 184 & 172 & 185 & 182 & 178 & 174 & 170 & 173 & 174 \\
Bangladesh & 169 & 168 & 170 & 169 & 175 & 172 & 172 & 175 & 175 \\
Sudan & 166 & 174 & 174 & 185 & 176 & 167 & 175 & 179 & 176 \\
Myanmar & 185 & 186 & 182 & 176 & 167 & 169 & 176 & 177 & 177 \\
Albania & 177 & 178 & 180 & 183 & 183 & 177 & 177 & 176 & 178 \\
Azerbaijan & 181 & 182 & 179 & 181 & 180 & 179 & 183 & 181 & 179 \\
Afghanistan & 186 & 183 & 183 & 179 & 181 & 182 & 181 & 180 & 180 \\
Armenia & 179 & 184 & 184 & 186 & 185 & 181 & 182 & 183 & 181 \\
Venezuela (Bolivarian Republic of $)$ & 150 & 143 & 140 & 153 & 159 & 151 & 169 & 182 & 182 \\
Yemen & 178 & 179 & 178 & 180 & 182 & 183 & 184 & 184 & 183 \\
Nigeria & 187 & 187 & 187 & 187 & 186 & 184 & 185 & 185 & 184 \\
India & 188 & 188 & 188 & 188 & 187 & 185 & 186 & 186 & 185 \\
South Sudan & NA & NA & NA & NA & NA & NA & NA & 74 & NA \\
Cook Islands & 20 & 23 & 24 & 26 & 25 & NA & 27 & NA & NA \\
Niue & 13 & 8 & 11 & 11 & 13 & NA & NA & NA & NA \\
Monaco & NA & NA & NA & 21 & NA & NA & NA & NA & NA \\
Syrian Arab Republic & 145 & 148 & 147 & NA & NA & NA & NA & NA & NA \\
\hline & & & & & & & & &
\end{tabular}

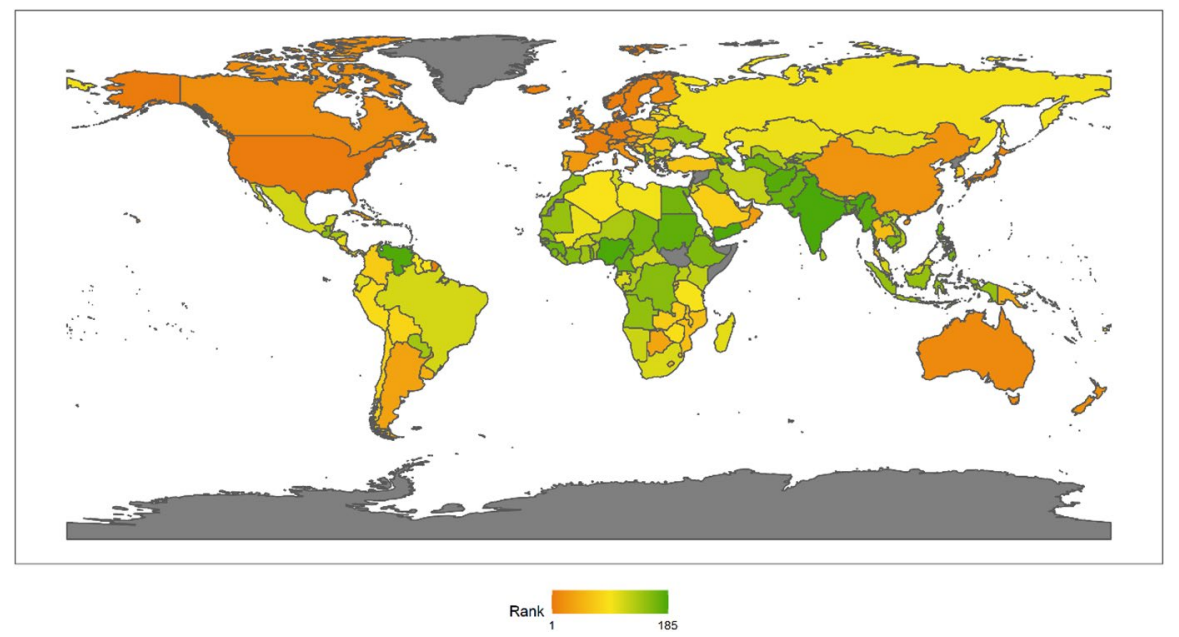

Fig. 19 The score of public health issue across continents, 2010-2018 


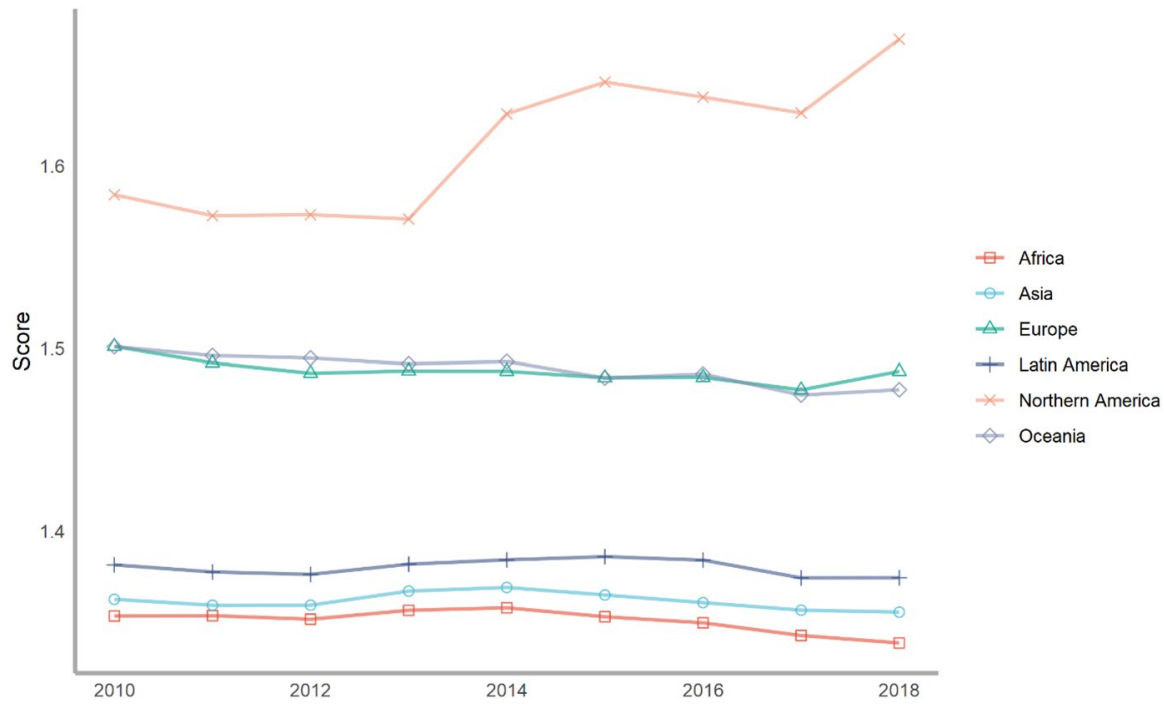

Fig. 20 Index ranking of public health on a world map, 2018

health. ${ }^{137}$ In other words, a country will improve global justice by providing public health services to its citizens.

\subsubsection{Dimensions and Indicators}

We measure the contribution of a country's public health to global justice from two perspectives. The first is the performance of each country's public health with respect to protection of an individual's right to health. We pay attention to the performance of basic public health from the perspective of global justice. We further divide the performance of public health into three dimensions, namely life expectancy and mortality, public health infrastructure, and key diseases. Specifically, (1) we use life expectancy at birth and life expectancy at age 60 to proxy for life expectancy and use the infant mortality rate, neonatal mortality rate, under five mortality rate, and the adult mortality rate to proxy for mortality. (2) For public health infrastructure, we adopt an indicator of the population using at least basic sanitation services, population using at least basic drinking water services to measure public health infrastructure. The indicator of Population practicing open defecation, is not adopted this year since the rate of missing values of this indicator is disproportionately high in high-income countries. (3) We use four indicators to measure key diseases: treatment success rate of new TB cases, tuberculosis effective treatment coverage, raised fasting blood glucose and incidence of tuberculosis.

137 Gu et al. (2020). 
The second perspective assesses the contribution of each country's government to public health. We adopt two indicators: current health expenditure per capita and domestic general government health expenditure per capita, to measure for a country's effort to promote its citizens' public health. These data are drawn from the WHO and cover 190 countries from 2010 to $2018 .^{138}$ The details can be found in Table 20 .

\subsubsection{Results}

Table 21 shows the ranking of countries the education issues area from 2010 to 2018. Taking 2018 as an example, the top 10 countries in the ranking are the USA, Norway, Germany, Iceland, France, Luxembourg, Sweden, Denmark, Japan, and Belgium, all of which are developed countries. The bottom ten countries are Sudan, Myanmar, Albania, Azerbaijan, Afghanistan, Armenia, Venezuela, Yemen, Nigeria and India, all of which are underdeveloped countries.

\subsubsection{Regional Analysis}

As shown in Fig. 19, North America as a whole is far ahead of the rest of the world in term of the rank in public health. Both Europe and Oceania also perform very well. Africa is at the bottom of the rankings. The ranks of Asia and Latin America are slightly higher than that of Africa. It is worth noting that the rankings vary widely within continents. Specifically, North America, Western Europe, Australia and New Zealand, and Northern Europe make the top contribution to global justice in public health, while Southern Asia, Western Africa, Central Asia, Central Africa and Northern Africa are at the bottom (Fig. 20).

Asia The rank of Asia as a whole is only slightly higher than that of Africa, but lower than that of the rest of the world. However, as shown in Fig. 18, the rankings of Asian countries also vary widely. Specifically, countries in East Asia perform well in the issue of public health. For example, the ranks of Japan and China-9th and 21st, respectively - are higher than many high-income countries, including Spain, Portugal and Israel. Japan's all-cause mortality rate was the lowest in the OECD in 2017 while its life expectancy at birth reached approximately 84.2 years in 2017 , the highest in the OECD. ${ }^{139}$ Like other developing countries, China did not score well in the contribution dimension, ranking 106th among 185 countries in 2018. However, China ranked first in the performance dimension of public health in 2018, which is partly due to its large population size and its performance above the world average. In other words, although by developed countries' standards, China's government does not invest much into public health, it still provides a significant portion of population in the world with access to public health services that are above the world average.

\footnotetext{
138 See https://www.who.int/nutgrowthdb/database/en/.

139 See https://www.oecd-ilibrary.org/social-issues-migration-health/health-at-a-glance_19991312.
} 
South Asia is one of the worst regions in the public health issue area. South Asia's three most populous countries, namely India, Pakistan and Bangladesh, ranked last, third and fourth from the bottom in public health, respectively. This is partly due to their low government investment, their poor performance and large population size.

For example, India's health expenditure accounted for rough 3.5\% of its GDP, less than the world average (9.84\%). India's domestic general government health expenditure accounted for only $0.96 \%$ of GDP, less than $1 / 6$ of the world's average $(5.87 \%)$. And its domestic general government health expenditure accounted for approximately $30 \%$ of health expenditure, which is also less than the world's average $(59.5 \%)$.

Europe Europe as a whole performed very well in public health in 2018. Eight of the top 10 countries in the ranking of public health are in Europe, specifically Western and Northern Europe, namely, Norway, Germany, Iceland, France, Luxembourg, Sweden, Denmark and Belgium. It is worth noting that these countries perform very well on the performance dimension of public health in spite of their small population size, suggesting that they provide a high quality of public health service to their people. For example, the life expectancy at birth of the eight countries reached 82.7 (Norway),81.1 (Germany), 82.2 (Iceland), 82.6 (France), 82.2 (Luxembourg), 82.5 (Sweden), 81.2 (Denmark) and 81.6 years (Belgium), all of which are higher than the OECD average (80.7 years) in 2017, while all-cause mortality rates (defined as number of deaths per 1000,000 people) of the eight countries is 701 (Norway), 777 (Germany), 725 (Iceland), 678 (France), 659 (Luxembourg), 710 (Sweden), 799 (Denmark) and 741 (Belgium), all of which is lower than the OECD average (801 deaths per 1000,000 people) in $2017 .^{140}$

Another characteristic of these countries in public health is that they score highly in the contribution dimension of public health, suggesting that by the standards of the global average, these countries invest much into public health. It is estimated that health expenditure per capita of the government in the eight countries in 2018 are much higher than the average of the OECD countries. ${ }^{141}$

It is also worth noting that, however, the rankings of European countries also vary widely. As shows in Fig. 18, Eastern Europe performed worse than the rest of Europe, but still better than many countries from Africa, Asia and Latin America.

North America North America as a whole was far ahead of the rest of the world in the public health rankings in 2018. The United States and Canada ranked 1st and 16th in the world in 2018, respectively. The USA ranked 1st not only the overall issue area but also in the contribution dimension of public health. First, The USA's domestic general government health expenditure per capita in 2018 reached approximately 5323 US dollars, the highest among all of the countries we observed. By one estimate, in 2018 the US spent $16.9 \%$ of its GDP on health care, which was approximately twice as much as OECD countries' expenditure (8.8\% of GDP). The US's spending on health care is much higher than that of the other top 10 countries, such as Norway (10.2\%), Germany (11.2\%), Iceland (8.3\%), France (11.2\%), Luxembourg

${ }^{140}$ OECD (2019).
141 OECD (2019). 
(5.4\%), Sweden (11\%), Denmark (10.5\%), Japan (10.9\%) and Belgium (10.4\%). ${ }^{142}$ Second, public health spending on health in the USA during 2013-2016 accounted for $8.3 \%$ of total national GDP, which is less than some high-income countries, such as Sweden (10\%), Netherlands (9.5\%), Denmark (9.2\%), France (8.7\%) and Japan (8.6\%), but higher than other, for instance, Switzerland (7.7\%), UK (7.6\%), Canada (7.4\%) and Australia (6.3\%). ${ }^{143}$ Third, the private health spending in USA was also higher than that in OECD countries. It is estimated that the private health spending in the USA accounted for 50.9\% of total health spending in 2016, higher than the OECD average (25\%). ${ }^{144}$ Although the USA ranks 1st in the OECD for health care expenditure, its score in performance dimension is lower than the other OECD countries. ${ }^{145}$ In 2016, for example, life expectancy in the total population at birth in USA was 78.8 years, lower than that in Japan (83.9), Switzerland (83), Australia (82.5), France (82.4), Netherlands (81.6), UK (81), Denmark (80.8) and Germany (80.7). Maternal mortality is 26.4 deaths per 100,000 live births, which is much higher than other high-income countries, such as the UK (9.2), Germany (9), France (7.8), Canada (7.3), Netherlands (6.7), Japan (6.4), Switzerland (5.8), Australia (5.5), Sweden (4.4) and Denmark (4.2). Moreover, the infant mortality rate of 5.8 deaths per 1000 live births in the USA is also higher than that in the other high-income countries we mention above. ${ }^{146}$

Latin America As shown in Fig. 3.9.2, Latin America as a whole performs better than Asia and Africa. However, countries within Latin America varied widely in terms of public health in 2018. For example, Argentina and Cuba ranked 34th and 27th, respectively, while Venezuela ranked 182nd among 185 countries in 2018. It is estimated that life expectancy at birth for the whole population across Latin America reached 74.5 years on average in 2017. However, large within-continent variations existed. The countries with the longest life expectancy in 2017 were Costa Rica and Chile at just over 80 years, which very closed to the OECD average ( 80.7 years). In contrast, life expectancy at birth in Haiti, Guyana and Bolivia is less than 70 years. In Haiti, life expectancy at birth was only 63.6 years in $2017 .{ }^{147}$

Large within-continent variations also existed in health expenditure by governments. For instance, in 2017, general government health expenditure in Cuba accounted for $10.5 \%$ of GDP, which was higher than the $6.6 \%$ in OECD countries. And in Argentina and Uruguay, general government health expenditure reached 6.6\% of GDP, which was higher than the average (3.76\%) for Latin America. However, in Venezuela and Haiti, general government health expenditure only accounted for $0.2 \%$ and $1 \%$ of GDP in 2017. This largely explains why the two countries ranked so low in terms of public health.

\footnotetext{
142 OECD (2019).

143 Papanicolas et al. (2018).

144 Anderson et al. (2019).

145 The high health-sector prices may explain why the USA's score in performance dimension is lower than other high-income countries since the USA's expenditure on public health is far more than others.

146 Papanicolas et al. (2018).

147 OECD (2020).
} 
Africa Africa as a whole was the worst performer in public health. In both the performance and contribution dimensions of public health Africa scored poorly. For example, in 2016, there were at least 11 African countries with a life expectancy at birth below 60 years. And in 36 African countries, a child born in 2016 can expect to live an average of less than 65 years. ${ }^{148}$ The life expectancy at birth for Nigeria, which ranks 184th among 185 countries, in 2018 was only 54.3 years, which is less than that of India (69.1 years); and the infant mortality rate for Nigeria in 2018 was 75.7 deaths per 1000 live births, far more than that for India (29.7 deaths per 1000 births). Government health expenditure as a share of GDP is also low in Africa. For example, in 2016, the countries with the highest shares were Namibia (5.65\%), Eswatini (5.33\%), and Lesotho (5.15\%), all of which are lower than the average $(6.6 \%)$ of OECD countries. And in 2016, there were at least 26 countries with a share below $2 \%$ of GDP.

Oceania Oceania as a whole performed very well in terms of public health in 2018, however, the rankings of Oceanian countries in public health also vary widely. The two largest countries in Oceania, Australia and New Zealand, performed very well in the public health rankings in 2018. According to our ranking, Australia and New Zealand ranked 13th and 18th, respectively. However, other countries from Melanesia, Micronesia, and Polynesia did not perform so well. For example, life expectancies in Papua New Guinea and Fiji are only 64.3 and 67.3 years, respectively, which is far lower than the average (70.0 years) of life expectancy in lowermiddle- and low-income countries in the Asia Pacific region. Infant mortality rates in Papua New Guinea and Fiji in 2018 are 38 and 21.6 deaths per 1000 live births, which very close to the average (27.2 deaths per 1000 live births) in lower-middleand low-income countries in Asia Pacific region. However, these countries from Melanesia, Micronesia and Polynesia invest more into public health than those from Southeast and South Asia. For example, in Solomon Islands and Papua New Guinea, more than $75 \%$ of all health expenditure was paid for through government schemes and compulsory health insurance in 2017. By contrast, in some Southeast and South Asian countries, such as Myanmar, Bangladesh and Cambodia, less than $25 \%$ of health spending was through these schemes. ${ }^{149}$ Therefore, we observe that Oceania as a whole perform better than Asia in terms of public health.

\subsubsection{Conclusion}

Public health is one of the fundamental elements of global justice. We use data from the WHO to construct a country's score of public health for global justice from the perspectives of both the performance and contribution dimensions. We examine the relationship between the public health score and economic development, measured as GDP per capita. We use a weighted linear regression (WLR) to estimate the correlation between the public health score and GDP per capita by weighting by population size.

148 The data comes from WHO Global Health Observatory data repository.
149 World Health Organization. (2020). 


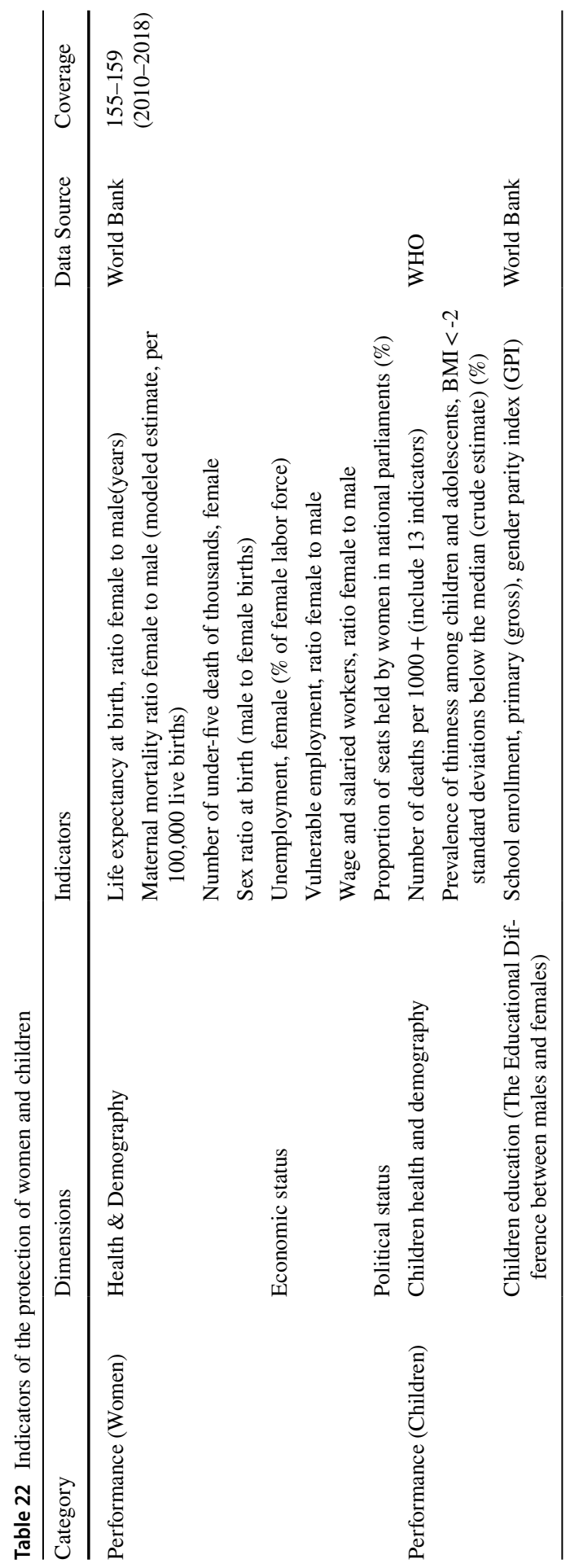


Table 23 Country ranking in the protection of women and children

\begin{tabular}{|c|c|c|c|c|c|c|c|c|c|}
\hline Country & 2010 & 2011 & 2012 & 2013 & 2014 & 2015 & 2016 & 2017 & 2018 \\
\hline China & 1 & 1 & 1 & 1 & 1 & 1 & 1 & 1 & 1 \\
\hline United States of America & 2 & 2 & 2 & 2 & 2 & 2 & 2 & 2 & 2 \\
\hline Russian Federation & 3 & 3 & 3 & 4 & 4 & 4 & 3 & 3 & 3 \\
\hline Brazil & 4 & 4 & 4 & 3 & 3 & 3 & 4 & 4 & 4 \\
\hline Germany & 5 & 5 & 5 & 6 & 6 & 6 & 6 & 5 & 5 \\
\hline Mexico & 9 & 9 & 8 & 9 & 8 & 7 & 8 & 6 & 6 \\
\hline $\begin{array}{l}\text { United Kingdom of Great Britain and } \\
\text { Northern Ireland }\end{array}$ & 6 & 6 & 7 & 7 & 7 & 8 & 7 & 7 & 7 \\
\hline France & 7 & 7 & 6 & 8 & 9 & 9 & 9 & 8 & 8 \\
\hline Italy & 8 & 8 & 9 & 10 & 10 & 10 & 10 & 9 & 9 \\
\hline Republic of Korea & 10 & 11 & 10 & 12 & 11 & 11 & 11 & 10 & 10 \\
\hline Thailand & 11 & 10 & 11 & 11 & 12 & 12 & 12 & 11 & 11 \\
\hline Poland & 16 & 14 & 14 & 14 & 15 & 14 & 13 & 12 & 12 \\
\hline Spain & 12 & 12 & 13 & 15 & 16 & 16 & 16 & 13 & 13 \\
\hline Ukraine & 18 & 18 & 16 & 17 & 13 & 15 & 14 & 14 & 14 \\
\hline Argentina & 14 & 13 & 12 & 13 & 14 & 13 & 15 & 15 & 15 \\
\hline Canada & 17 & 15 & 15 & 16 & 17 & 17 & 17 & 16 & 16 \\
\hline Viet Nam & 15 & 16 & 17 & 18 & 19 & 18 & 18 & 17 & 17 \\
\hline Australia & 19 & 19 & 19 & 20 & 20 & 20 & 19 & 18 & 18 \\
\hline Saudi Arabia & 28 & 26 & 24 & 21 & 22 & 22 & 22 & 20 & 19 \\
\hline Colombia & 27 & 25 & 25 & 23 & 21 & 21 & 20 & 19 & 20 \\
\hline Philippines & 13 & 17 & 18 & 19 & 18 & 19 & 21 & 21 & 21 \\
\hline Netherlands & 22 & 21 & 21 & 25 & 24 & 24 & 24 & 22 & 22 \\
\hline Romania & 26 & 28 & 27 & 30 & 28 & 27 & 25 & 23 & 23 \\
\hline Syrian Arab Republic & 32 & 23 & 23 & 22 & 23 & 23 & 23 & 24 & 24 \\
\hline Kazakhstan & 33 & 32 & 29 & 29 & 27 & 25 & 26 & 25 & 25 \\
\hline Malaysia & 20 & 20 & 20 & 24 & 25 & 26 & 28 & 26 & 26 \\
\hline Belarus & 25 & 27 & 28 & 28 & 29 & 29 & 27 & 27 & 27 \\
\hline Belgium & 29 & 29 & 30 & 31 & 30 & 31 & 29 & 28 & 28 \\
\hline Sweden & 30 & 30 & 31 & 32 & 32 & 32 & 31 & 29 & 29 \\
\hline Cuba & 24 & 24 & 26 & 27 & 31 & 30 & 30 & 30 & 30 \\
\hline Czechia & 31 & 31 & 32 & 33 & 33 & 33 & 32 & 31 & 31 \\
\hline Portugal & 35 & 33 & 34 & 36 & 35 & 35 & 33 & 32 & 32 \\
\hline Chile & 34 & 35 & 36 & 34 & 34 & 34 & 34 & 33 & 33 \\
\hline Uzbekistan & 46 & 43 & 40 & 37 & 37 & 38 & 38 & 34 & 34 \\
\hline Sri Lanka & 37 & 36 & 33 & 35 & 36 & 36 & 36 & 35 & 35 \\
\hline Turkey & 138 & 127 & 115 & 108 & 52 & 37 & 41 & 40 & 36 \\
\hline Hungary & 36 & 37 & 38 & 39 & 38 & 39 & 37 & 37 & 37 \\
\hline Dominican Republic & 49 & 47 & 42 & 43 & 42 & 45 & 44 & 36 & 38 \\
\hline Austria & 38 & 38 & 39 & 41 & 39 & 40 & 39 & 41 & 39 \\
\hline Israel & 40 & 39 & 41 & 42 & 43 & 41 & 40 & 38 & 40 \\
\hline Peru & 39 & 40 & 47 & 56 & 46 & 43 & 42 & 39 & 41 \\
\hline Lebanon & 54 & 52 & 52 & 49 & 49 & 49 & 45 & 44 & 42 \\
\hline
\end{tabular}


Table 23 (continued)

\begin{tabular}{|c|c|c|c|c|c|c|c|c|c|}
\hline Country & 2010 & 2011 & 2012 & 2013 & 2014 & 2015 & 2016 & 2017 & 2018 \\
\hline Bulgaria & 47 & 48 & 48 & 48 & 50 & 48 & 47 & 43 & 43 \\
\hline Finland & 43 & 41 & 43 & 44 & 45 & 46 & 46 & 45 & 44 \\
\hline Denmark & 44 & 45 & 46 & 46 & 48 & 50 & 49 & 46 & 45 \\
\hline Norway & 45 & 44 & 45 & 47 & 47 & 51 & 51 & 48 & 46 \\
\hline Switzerland & 42 & 42 & 44 & 45 & 44 & 47 & 48 & 47 & 47 \\
\hline Tunisia & 56 & 56 & 55 & 50 & 51 & 52 & 53 & 49 & 48 \\
\hline Ireland & 51 & 51 & 53 & 52 & 56 & 54 & 54 & 50 & 49 \\
\hline Slovakia & 50 & 50 & 51 & 51 & 54 & 55 & 55 & 52 & 50 \\
\hline Serbia & 53 & 54 & 54 & 54 & 55 & 53 & 52 & 51 & 51 \\
\hline Venezuela (Bolivarian Republic of) & 23 & 22 & 22 & 26 & 26 & 28 & 35 & 42 & 52 \\
\hline Greece & 41 & 46 & 49 & 55 & 57 & 57 & 60 & 54 & 53 \\
\hline Kyrgyzstan & 57 & 57 & 58 & 60 & 59 & 59 & 58 & 53 & 54 \\
\hline Kuwait & 61 & 61 & 59 & 59 & 60 & 60 & 59 & 55 & 55 \\
\hline New Zealand & 52 & 53 & 56 & 57 & 58 & 58 & 57 & 56 & 56 \\
\hline Costa Rica & 55 & 55 & 57 & 58 & 61 & 62 & 61 & 57 & 57 \\
\hline Republic of Moldova & 58 & 58 & 61 & 61 & 62 & 61 & 63 & 58 & 58 \\
\hline Croatia & 59 & 60 & 63 & 63 & 64 & 64 & 65 & 60 & 59 \\
\hline Lithuania & 60 & 62 & 60 & 62 & 65 & 63 & 64 & 59 & 60 \\
\hline Tajikistan & 64 & 68 & 65 & 64 & 69 & 68 & 66 & 61 & 61 \\
\hline Qatar & 70 & 72 & 72 & 67 & 70 & 69 & 69 & 64 & 62 \\
\hline Uruguay & 62 & 67 & 66 & 65 & 68 & 67 & 67 & 63 & 63 \\
\hline Panama & 65 & 64 & 67 & 66 & 66 & 66 & 68 & 65 & 64 \\
\hline Ecuador & 48 & 49 & 50 & 53 & 53 & 56 & 62 & 62 & 65 \\
\hline Mongolia & 68 & 71 & 70 & 69 & 71 & 71 & 72 & 66 & 66 \\
\hline Slovenia & 63 & 66 & 68 & 68 & 72 & 73 & 71 & 68 & 67 \\
\hline Georgia & 72 & 73 & 74 & 73 & 75 & 74 & 70 & 69 & 68 \\
\hline Nicaragua & 69 & 63 & 64 & 70 & 74 & 70 & 75 & 72 & 69 \\
\hline Latvia & 67 & 70 & 71 & 71 & 73 & 72 & 74 & 71 & 70 \\
\hline El Salvador & 66 & 69 & 69 & 74 & 67 & 65 & 73 & 70 & 71 \\
\hline Estonia & 71 & 73 & 73 & 75 & 76 & 76 & 76 & 73 & 72 \\
\hline Albania & 84 & 81 & 80 & 81 & 80 & 79 & 78 & 74 & 73 \\
\hline Bolivia (Plurinational State of) & 114 & 114 & 109 & 112 & 101 & 86 & 77 & 75 & 74 \\
\hline Republic of North Macedonia & 78 & 76 & 76 & 80 & 81 & 82 & 80 & 78 & 75 \\
\hline Trinidad and Tobago & 75 & 79 & 77 & 77 & 78 & 81 & 79 & 77 & 76 \\
\hline Cyprus & 74 & 74 & 75 & 78 & 82 & 85 & 82 & 79 & 77 \\
\hline Bahrain & 79 & 80 & 79 & 80 & 83 & 84 & 84 & 81 & 78 \\
\hline Mauritius & 77 & 78 & 78 & 79 & 84 & 83 & 83 & 80 & 79 \\
\hline Armenia & 102 & 101 & 99 & 104 & 93 & 87 & 85 & 82 & 80 \\
\hline Paraguay & 76 & 77 & 81 & 72 & 77 & 75 & 81 & 83 & 81 \\
\hline Montenegro & 81 & 83 & 82 & 82 & 87 & 88 & 86 & 84 & 82 \\
\hline Malta & 83 & 84 & 83 & 83 & 88 & 88 & 87 & 85 & 83 \\
\hline Luxembourg & 80 & 82 & 84 & 84 & 86 & 89 & 88 & 86 & 84 \\
\hline
\end{tabular}


Table 23 (continued)

\begin{tabular}{|c|c|c|c|c|c|c|c|c|c|}
\hline Country & 2010 & 2011 & 2012 & 2013 & 2014 & 2015 & 2016 & 2017 & 2018 \\
\hline Iceland & 82 & 85 & 85 & 85 & 89 & 90 & 89 & 87 & 85 \\
\hline Bahamas & 85 & 86 & 86 & 86 & 90 & 91 & 91 & 88 & 86 \\
\hline Suriname & 88 & 89 & 88 & 87 & 92 & 92 & 92 & 89 & 87 \\
\hline Barbados & 86 & 88 & 87 & 88 & 91 & 93 & 93 & 90 & 88 \\
\hline Cabo Verde & 97 & 99 & 97 & 97 & 104 & 101 & 98 & 91 & 89 \\
\hline Brunei Darussalam & NA & NA & NA & NA & NA & NA & 94 & 92 & 90 \\
\hline Belize & 96 & 97 & 95 & 94 & 100 & 97 & 99 & 93 & 91 \\
\hline Saint Lucia & 91 & 92 & 91 & 90 & 94 & 94 & 95 & 94 & 92 \\
\hline Samoa & 90 & 93 & 92 & 91 & 95 & 95 & 96 & 95 & 93 \\
\hline Saint Vincent and the Grenadines & 94 & 94 & 93 & 92 & 97 & 98 & 97 & 96 & 94 \\
\hline Tonga & 93 & 95 & 94 & 93 & 99 & 99 & 100 & 97 & 95 \\
\hline Fiji & 87 & 91 & 90 & 89 & 96 & 96 & 101 & 98 & 96 \\
\hline Solomon Islands & 92 & 96 & 96 & 95 & 102 & 102 & 102 & 100 & 97 \\
\hline Vanuatu & 95 & 98 & 98 & 96 & 103 & 103 & 103 & 101 & 98 \\
\hline Sao Tome and Principe & 98 & 100 & 100 & 100 & 105 & 104 & 104 & 102 & 99 \\
\hline Maldives & 99 & 103 & 102 & 102 & 106 & 105 & 105 & 104 & 100 \\
\hline Guyana & 100 & 102 & 101 & 103 & 107 & 106 & 106 & 103 & 101 \\
\hline Democratic People's Republic of Korea & NA & NA & NA & NA & NA & 80 & NA & NA & 102 \\
\hline Algeria & 109 & 59 & 35 & 40 & 40 & 44 & 56 & 76 & 103 \\
\hline Honduras & 73 & 65 & 62 & 76 & 79 & 78 & 90 & 99 & 104 \\
\hline Bhutan & 101 & 104 & 103 & 105 & 108 & 107 & 108 & 106 & 105 \\
\hline Oman & 89 & 87 & 89 & 98 & 98 & 100 & 107 & 105 & 106 \\
\hline Azerbaijan & 105 & 90 & 105 & 107 & 110 & 113 & 110 & 108 & 107 \\
\hline Timor-Leste & 103 & 105 & 104 & 106 & 109 & 108 & 109 & 107 & 108 \\
\hline Iran (Islamic Republic of) & 131 & 124 & 119 & 99 & 63 & 77 & 116 & 67 & 109 \\
\hline Senegal & 128 & 128 & 124 & 125 & 124 & 123 & 125 & 121 & 110 \\
\hline Djibouti & 107 & 107 & 107 & 110 & 113 & 111 & 111 & 109 & 111 \\
\hline Comoros & 106 & 106 & 106 & 109 & 112 & 110 & 112 & 110 & 112 \\
\hline Botswana & 108 & 108 & 108 & 111 & 115 & 112 & 114 & 111 & 113 \\
\hline Cambodia & 110 & 110 & 110 & 113 & 114 & 109 & 113 & 112 & 114 \\
\hline Eswatini & 118 & 113 & 112 & 115 & 116 & 115 & 115 & 113 & 115 \\
\hline Namibia & 112 & 112 & 113 & 116 & 118 & 117 & 118 & 114 & 116 \\
\hline Lesotho & 119 & 117 & 116 & 118 & 121 & 120 & 120 & 117 & 117 \\
\hline Rwanda & 117 & 118 & 118 & 119 & 119 & 116 & 117 & 116 & 118 \\
\hline Equatorial Guinea & 111 & 109 & 111 & 114 & 117 & 118 & 119 & 115 & 119 \\
\hline Gambia & 115 & 115 & 114 & 117 & 120 & 119 & 121 & 118 & 120 \\
\hline Guatemala & 104 & 75 & 117 & 101 & 111 & 114 & 122 & 119 & 121 \\
\hline Lao People's Democratic Republic & 120 & 120 & 121 & 120 & 123 & 122 & 123 & 120 & 122 \\
\hline Myanmar & 139 & 139 & 139 & 137 & 135 & 133 & 133 & 132 & 123 \\
\hline Mauritania & 121 & 119 & 120 & 121 & 122 & 121 & 124 & 122 & 124 \\
\hline Papua New Guinea & 122 & 122 & 125 & 122 & 126 & 124 & 126 & 123 & 125 \\
\hline Congo & 123 & 121 & 123 & 123 & 125 & 125 & 127 & 124 & 126 \\
\hline
\end{tabular}


Table 23 (continued)

\begin{tabular}{|c|c|c|c|c|c|c|c|c|c|}
\hline Country & 2010 & 2011 & 2012 & 2013 & 2014 & 2015 & 2016 & 2017 & 2018 \\
\hline Burundi & 127 & 130 & 129 & 127 & 129 & 127 & 129 & 125 & 127 \\
\hline Togo & 126 & 125 & 127 & 126 & 128 & 126 & 130 & 126 & 128 \\
\hline Liberia & 125 & 123 & 126 & 124 & 127 & 128 & 128 & 127 & 129 \\
\hline Madagascar & 132 & 132 & 130 & 129 & 130 & 129 & 131 & 128 & 130 \\
\hline Central African Republic & 130 & 131 & 131 & 130 & 131 & 132 & 132 & 129 & 131 \\
\hline Morocco & 129 & 126 & 128 & 128 & 132 & 130 & 135 & 130 & 132 \\
\hline Nepal & 124 & 129 & 132 & 131 & 133 & 131 & 134 & 131 & 133 \\
\hline Malawi & 135 & 134 & 133 & 134 & 134 & 134 & 136 & 133 & 134 \\
\hline Sierra Leone & 136 & 136 & 136 & 135 & 136 & 135 & 137 & 135 & 135 \\
\hline Zambia & 137 & 137 & 137 & 138 & 138 & 136 & 138 & 134 & 136 \\
\hline Uganda & 142 & 142 & 141 & 141 & 141 & 139 & 140 & 137 & 137 \\
\hline Niger & 143 & 140 & 140 & 140 & 142 & 142 & 143 & 140 & 138 \\
\hline Benin & 133 & 133 & 135 & 136 & 137 & 137 & 139 & 136 & 139 \\
\hline Burkina Faso & 141 & 138 & 146 & 142 & 144 & 141 & 145 & 142 & 140 \\
\hline South Africa & 152 & 147 & 143 & 144 & 143 & 140 & 142 & 139 & 141 \\
\hline Guinea & 134 & 135 & 138 & 139 & 139 & 138 & 141 & 138 & 142 \\
\hline Ghana & 140 & 141 & 142 & 143 & 145 & 143 & 146 & 141 & 143 \\
\hline Indonesia & 21 & 34 & 122 & 132 & 140 & 144 & 144 & 143 & 144 \\
\hline Chad & 145 & 143 & 144 & 145 & 146 & 145 & 147 & 145 & 145 \\
\hline United Republic of Tanzania & 146 & 146 & 148 & 150 & 150 & 146 & 148 & 144 & 146 \\
\hline Cameroon & 149 & 148 & 149 & 148 & 148 & 148 & 149 & 146 & 147 \\
\hline Mali & 147 & 145 & 145 & 146 & 147 & 147 & 150 & 147 & 148 \\
\hline Afghanistan & 151 & 150 & 151 & 149 & 151 & 151 & 151 & 149 & 149 \\
\hline Mozambique & 148 & 149 & 150 & 151 & 152 & 152 & 153 & 150 & 150 \\
\hline Yemen & 144 & 144 & 147 & 147 & 149 & 149 & 152 & 148 & 151 \\
\hline Bangladesh & 155 & 155 & 155 & 155 & 154 & 154 & 157 & 151 & 152 \\
\hline Kenya & 153 & 152 & 152 & 152 & 153 & 153 & 155 & 153 & 153 \\
\hline Egypt & 156 & 154 & 154 & 154 & 155 & 156 & 154 & 154 & 154 \\
\hline Ethiopia & 154 & 153 & 153 & 153 & 156 & 155 & 156 & 152 & 155 \\
\hline Democratic Republic of the Congo & 157 & 156 & 156 & 156 & 157 & 157 & 158 & 155 & 156 \\
\hline India & 160 & 159 & 159 & 158 & 159 & 159 & 159 & 156 & 157 \\
\hline Pakistan & 158 & 157 & 157 & 157 & 158 & 158 & 160 & 157 & 158 \\
\hline Nigeria & 159 & 158 & 158 & 159 & 160 & 160 & 161 & 158 & 159 \\
\hline Guinea-Bissau & 116 & NA & NA & NA & NA & NA & NA & NA & NA \\
\hline Eritrea & 113 & 116 & NA & NA & NA & NA & NA & NA & NA \\
\hline Angola & 150 & 151 & NA & NA & NA & 150 & NA & NA & NA \\
\hline Japan & NA & NA & NA & 5 & 5 & 5 & 5 & NA & NA \\
\hline Zimbabwe & NA & NA & 134 & 133 & NA & NA & NA & NA & NA \\
\hline Singapore & NA & NA & NA & NA & NA & NA & 50 & NA & NA \\
\hline Gabon & NA & 111 & NA & NA & NA & NA & NA & NA & NA \\
\hline United Arab Emirates & NA & NA & 37 & 38 & 41 & 42 & 43 & NA & NA \\
\hline Turkmenistan & NA & NA & NA & NA & 85 & NA & NA & NA & NA \\
\hline
\end{tabular}


The fitting line of the WLR reveals a high correlation between a country's contribution of public health to global justice and its economic development. Although these highincome countries perform well in the contribution of public health to global justice, the richest countries, such as Switzerland, Norway, Ireland, Iceland, Qatar and Singapore are below the fitting line. In addition, Venezuela and India are also far below the fitting line. This suggests that by the standard of economic development, these counties do less well than expected.

Based on a WLR, we also to find a high correlation between the score of contribution in public health issue and GDP per capita, suggesting that high-income countries as a whole invest much in public health. Again, by the standard of economic development, the richest countries, such as Switzerland, Norway, Ireland, Iceland, Qatar and Singapore, do not invest as much as expected. It is worth noting that, however, these countries performed very well in the performance dimension of public health, suggesting that unlimited financial expenditure on public health is not a sufficient and necessary conditions of good performance. Besides, many African countries are above the fitting line of the WLR of contribution on GDP per capita, suggesting that given their low GDP per capita, these countries invest more in public health than expected. However, unfortunately, when we use a fitting line of a WLR of unweighted performance on contribution and in public health to, we find that many African countries are below the fitting line of the WLR. A disproportionate relationship between the scores of contribution dimension and unweighted performance in many African countries, suggesting inefficiency in these countries' investment in public health.

Last but not least, we find a weak correlation between the unweighted performance score in public health issue and GDP per capita. This may be because we only focus on basic public health. There is a ceiling effect of basic public health in terms of global justice, that is, when the economy develops to a certain level (e.g., when GDP per capita exceeds 10,000 US dollars as shown in this figure), the continued development of the economy does not necessarily improve its opportunities for basic public health. When we focus on underdeveloped countries with a GDP per capita of less than 10,000 UD dollars, we find a highly positive correlation between unweighted performance score in the public health issue area and GDP per capita, suggesting that when the higher the GDP per capita in underdeveloped countries, the better performance in public health, and that many African countries score of unweighted performance in public health is very low.

\subsection{Issue 10: Protection of Women and Children}

\subsubsection{Introduction}

Protection of women and children is an important part of human rights treaties and it is essential for the achievement of global justice. There are various rankings relating to this issue across the world. For example, the Gender Inequality Index (GII) of the United Nations Development Programme measures gender inequalities in three important aspects of human development-reproductive health, empowerment and economic status. The Social Institutions and Gender Index (SIGI) of the OECD 
Development Center measures discrimination against women by taking into account laws, social norms and practices. The Kidsrights Index of the KidsRights Foundation is the first and only global ranking that annually measures how children's rights are protected and to what extent countries are committed to improving the rights of children. At the regional level, there is the Gender Equality Index measuring the progress of gender equality in the EU. Most of these indexes measure the protection of women and children from the perspective of human rights. Considering that our research focuses on the contributions of different states to global justice, we use a population-based weighed score of indices to construct our scores on this issue from the perspective of global justice. In this way, our index is distinguished from most of the existing indexes and fills a gap in the measurement of protection of women and children from the perspective of global justice.

\subsubsection{Dimensions and Indicators}

The basic framework of indicators remains the same as our measurement last year. It is difficult to distinguish a country's financial contribution to the protection of women and children from other issues such as public health, education, and poverty. However, a country's performance on this issue is clear and measurable. As a result, for this issue area we focus only on the performance dimension. First, we use the ratio of health, demography, economic status, and political empowerment between males and females to measure gender inequality from the perspective of gender-based gaps in resources and opportunities in countries. Second, we focus on the gender difference of children's situations from the perspective of poverty, health and education.

Table 22 shows the detailed information about the indicators we use. Data on children's health and demography is obtained from the WHO, and the remainder are obtained from the World Bank.

\subsubsection{Results}

According to the results, China remained in first place in the protection of women and children from 2010 to 2018 (Table 23). However, it $t$ is worth noting that we used a population-based weighted score of indices to construct the scores for this issue from the perspective of global justice. As a result, the score here indicates not the level of protection for women and children in respect of an individual country's situation, but the country's total contribution in improving women and children's living situation as a whole. Specifically, we set up a base line, and if a country performed better than the base line, the more women and children in this country, the higher the score it gets. However, if a country performed worse than the base line, the more women and children in this country, the lower the score is. This explains why China ranked the first while India, a country with a large population, ranked 157 th in 2018.

The United States remained in second place in this issue from 2010 to 2018. Countries with a large population who performed better than the base line ranked 


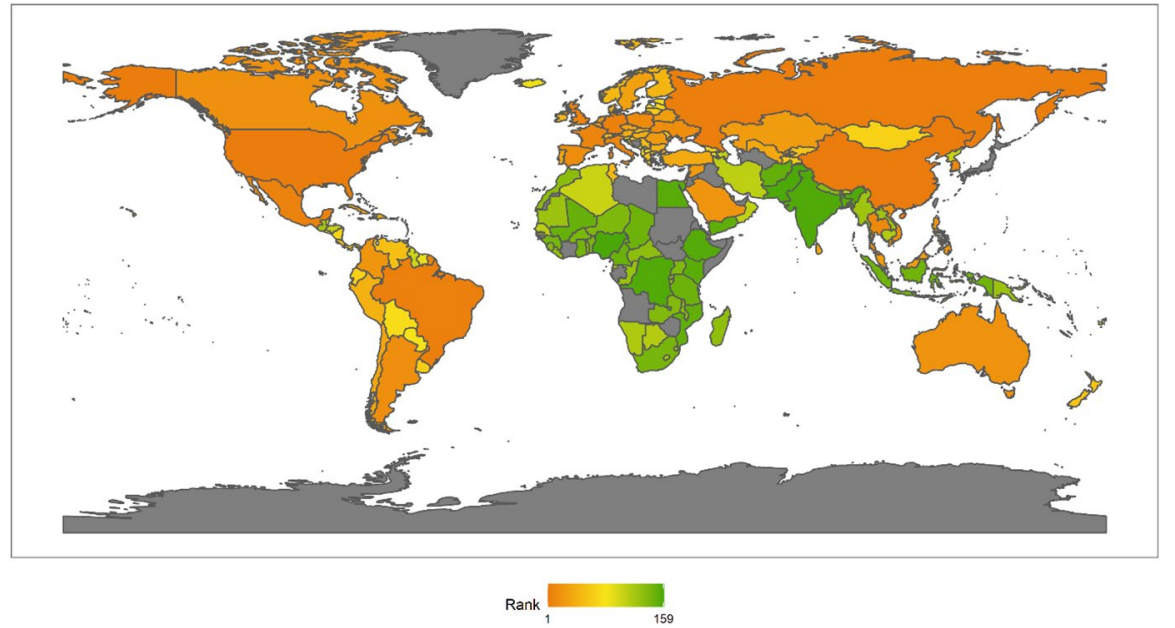

Fig. 212018 Index ranking of the protection of women and children on a world map

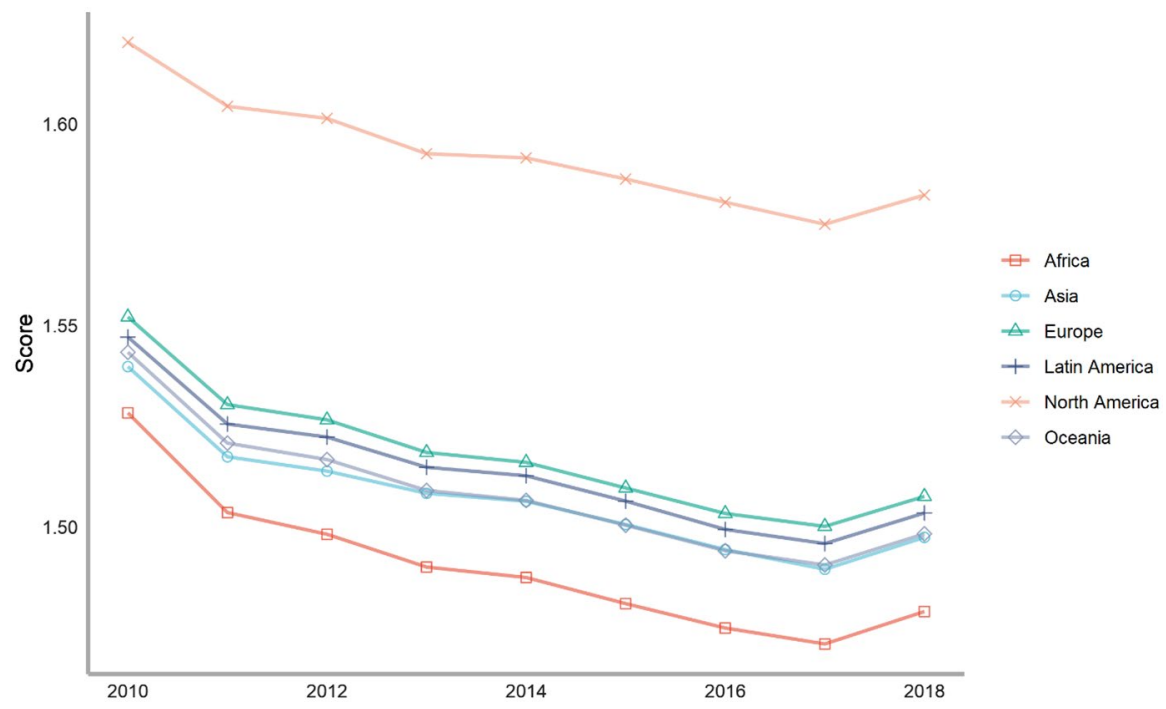

Fig. 22 The score of Protection of Women and Children across continents, 2010-2018

at the forefront as well, such as Russia, Brazil, and Mexico. Those countries with a large population but performed worse than the base line ranked at the bottom, such as Indonesia, India and Pakistan. Traditional democratic countries in Europe also ranked highly, including Germany, the UK, France and Italy.

The top ten countries in 2018 were China, the United States, Russia, Brazil, Germany, Mexico, the United Kingdom, France, Italy and Korea (Fig. 21). As we discussed earlier, a higher score does not denote a higher level of protection for women 
and children from an individual perspective, but rather means a higher improvement in conditions across all women and children. Thus, the fact that China ranked first reflected that China has made many women and children far better off than the world average.

\subsubsection{Regional Analysis}

\section{See Fig. 22.}

Asia According to our result, East Asian countries such as China, Korea and Japan contributed greatly on this issue. At the regional level, ASEAN, as mentioned above in the section on transnational organized crime also plays a role in the protection of women and children. All of the ASEAN member states have ratified to the Convention on the Elimination of all Forms of Discrimination against Women (CEDAW) and the Convention on the Rights of the Child (CRC).

China ranked the first under our measurement of this issue. The Chinese government issued a series of policy papers, including national laws, local regulations and administrative rules, to protect women's rights and interests. Taking women's employment rights as an example, the 1992 Law on the Protection of Rights and Interests of Women is the main piece of legislation regarding the protection of women in the workplace. Additionally, the Constitutional Principle (1954), the Regulation Governing Labour Protection for Female Staff and Workers (1988), the Labour Law (1994), the Law on the Protection of Women's Rights and Interests (1992, revised 2005), the Employment Promotion Law (2008) and the Employment Contract Law (2008) provide legal protections to women in the workplace. ${ }^{150}$ In regard to the protection of children, China has also established a legal framework to protect children's interests and rights. The framework is composed of conventions of the UN, international organizations and NGOs, laws issued by the National People's Congress and its Standing Committee, administrative regulations of the State Council and local rules and relevant regulations.

Europe Gender equality and protection of children are foundational values under the EU treaties and are common topics in EU meetings. The Council of Europe has established a Committee for Equality between Women and Men, and the European Court of Human Rights also plays a role in the protection of women and children protection at the judicial level. For example, the European Court in different judgments has held the governments of Belgium, Denmark, Ireland, the Netherlands, Switzerland and the UK to be in violation of their duties to respect the human rights of women. ${ }^{151}$ In 2018, the EU adopted a new strategic approach to women, peace and security. In the Council conclusions, it emphasized the importance of full implementation of the Women, Peace and Security (WPS) agenda by all its member states and affirmed that the implementation of the EU Strategic Approach to WPS should be achieved through political and diplomatic engagement by the EU leadership. There are a large number of associations and organizations protecting the rights

150 Sadie Yang and Ao Li (2009).

151 Rebecca (1995). 
and interests of women and children. For example, the European Women's Lobby, which aimed to "exert pressure on European and national institutions to ensure better defense and representation of women's interests". 152

North America In North America, violence towards women and children is a widely focused social issue. The US government has established a legal framework against gender-based violence and violence towards children over the past several decades. President Clinton signed the Violence against Women Act (VAWA) into law in 1994. VAWA represents significant progress in the legal protection against gender-based violence. It emphasizes a coordinated community response to different types of violence including domestic violence, dating violence, sexual assault, stalking, etc. The Act also granted 1.6 billion dollars towards the investigation and prosecution of violent crimes directed towards women. Additionally, VAWA established the Office on Violence against Women within the Department of Justice. In Canada, Canada's Strategy to Prevent and Address Gender-Based Violence (the Strategy) was issued in 2017 and acts as the main regulation against gender-based violence. The Strategy's initiatives are organized across three pillars: preventing gender-based violence, supporting survivors and their families, and promoting responsive legal and justice systems. Additionally, the Canadian government provided over 200 million dollars (over 40 dollars per year) for the establishment and implementation of the Strategy. ${ }^{153}$

Latin America Latin America is a region with relatively serious problems of inequality, discrimination and violence towards women and children. According to data from the UNDP, more than 14 countries in Latin America and the Caribbean have categorized femicide as a crime. In Brazil, Chile, Bolivia, Colombia, Ecuador, Peru, Costa Rica, El Salvador, Guatemala, Honduras, Mexico, Nicaragua, Panama and Dominica, laws have been passed against femicide and other forms of violence against women. Antigua and Barbuda, Argentina, Bahamas, Barbados, Belize, Bolivia, Brazil, Chile, Colombia, Costa Rica, Dominica, Dominican Republic, Ecuador, El Salvador, Grenada, Guatemala, Guyana, Haiti, Honduras, Jamaica, Mexico, Nicaragua, Panama, Paraguay, Peru, Saint Kitts and Nevis, St. Lucia, St. Vincent and the Grenadines, Suriname, Trinidad y Tobago, Uruguay and Venezuela are signatory countries to the Inter-American Convention on the Prevention, Punishment and Eradication of Violence Against Women. However, to achieve a comprehensive realization of human rights protection there are still serious challenges to overcome. $^{154}$

Africa Gender-based violence and violence towards children are severe problems in Africa due to a complex combination of conditions including hunger, poverty, conflicts and war. According to data from the World Economic Forum, 137 women around the world are killed by a family member each day, and 52 of them are in Africa. To improve women's empowerment in Africa, the World Bank initiated the Sahel Women's Empowerment and Demographic Dividend project at the demand of

152 https://womenlobby.org/?lang=en.
153 https://cfc-swc.gc.ca/violence/strategy-strategie/index-en.html.
154 UNDP (2017). 
the governments of Benin, Burkina Faso, Chad, Cote d'Ivoire, Mali, Mauritania and Niger. The project helped women to access to opportunities for education, employment, and engagement in policymaking. In regard to the protection of children, the United Nations Convention on the Rights of the Child (CRC) and the African Charter on the Rights and Welfare of the Child (ACRWC) are the main legal instruments to protect children from various problems including violence, child labor and military use of children. Article 19 of the CRC and Article 16 of the ACRWC require that member states should take all appropriate measures to prevent children from violence, maltreatment and abuse. ${ }^{155}$

Oceania Over the last several years, the Australian government has issued a series of policies and regulations to protect women from various forms of violence, such as the National Plan to Reduce Violence against Women and their Children 2010-2022 by the Council of Australian Governments in 2010 and The Time for Action: The National Council's Plan for Australia to Reduce Violence Against Women and Their Children 2009-2021 by the National Council. Additionally, the National Plan has led to the establishment of two organizations relating to violence against women: Australia's National Organisation for Women's Safety and the National Foundation to Prevent Violence against Women and their Children. The former focuses on the promotion of national research activities to solve relevant problems, and the latter endeavors to induce changes culture, behavior and power imbalances. Strategies and policies have also been released at the territory level to promote gender equality and prevent violence. For example, the Achieving Women's Equality was released in 2015 by the South Australian Government, and the Queensland Women's Strategy 2016-2021 put forward by the Queensland Government in 2016. ${ }^{156}$

\subsubsection{Conclusion}

The protection of women and children, as a component of fundamental human rights, has long been an important part of the achievement of global justice. Legal frameworks and judicial systems have been established in most countries to protect women's rights to education, employment and engagement in policy-making as well as protecting children from all forms of violence, maltreatment and abuse. However, there are still important challenges to overcome to achieve a comprehensive protection of women and children. We measured the performance and contribution of each nation state in this issue across 11 indicators in all. Eight of these, including life expectancy, maternal mortality ratio, death ratio, sex ratio, unemployment, vulnerable employment, wages and salaries, and proportion of seats held by women in national parliaments, were used to measure the protection of women, while three (number of deaths per $1000+$, prevalence of thinness among children and adolescents, and school enrollment) were used to measure the protection of children. According to the results, the top ten countries in 2018 are China, the United States, Russia, Brazil, Germany, Mexico, the United Kingdom, France, Italy and Korea.

\footnotetext{
155 Marisa and Amanda (2014).

156 Vichealth (2017).
} 
Table 24 Global Justice Index (except for both climate change and anti-poverty)

\begin{tabular}{|c|c|c|c|c|c|c|c|c|c|}
\hline Country & 2010 & 2011 & 2012 & 2013 & 2014 & 2015 & 2016 & 2017 & 2018 \\
\hline United States of America & 1 & 1 & 1 & 1 & 1 & 1 & 1 & 1 & 1 \\
\hline Germany & 3 & 3 & 3 & 4 & 3 & 3 & 2 & 2 & 2 \\
\hline $\begin{array}{l}\text { United Kingdom of Great Britain } \\
\text { and Northern Ireland }\end{array}$ & 2 & 2 & 2 & 2 & 2 & 2 & 3 & 3 & 3 \\
\hline Sweden & 6 & 5 & 5 & 5 & 6 & 6 & 7 & 5 & 4 \\
\hline Norway & 5 & 6 & 6 & 7 & 7 & 7 & 6 & 6 & 5 \\
\hline China & 4 & 4 & 4 & 6 & 5 & 5 & 5 & 4 & 6 \\
\hline Canada & 7 & 7 & 7 & 8 & 9 & 9 & 8 & 7 & 7 \\
\hline Belgium & 14 & 13 & 11 & 13 & 13 & 13 & 11 & 10 & 8 \\
\hline Italy & 8 & 8 & 8 & 9 & 8 & 8 & 9 & 8 & 9 \\
\hline Finland & 11 & 12 & 9 & 11 & 10 & 12 & 12 & 12 & 10 \\
\hline Switzerland & 12 & 11 & 10 & 12 & 12 & 11 & 13 & 11 & 11 \\
\hline Denmark & 9 & 10 & 12 & 10 & 11 & 10 & 10 & 9 & 12 \\
\hline Netherlands & 13 & 14 & 13 & 14 & 14 & 14 & 14 & 14 & 13 \\
\hline Austria & 16 & 16 & 18 & 18 & 18 & 19 & 17 & 16 & 14 \\
\hline Spain & 10 & 9 & 14 & 15 & 15 & 15 & 15 & 13 & 15 \\
\hline Australia & 15 & 15 & 17 & 17 & 20 & 20 & 19 & 17 & 16 \\
\hline New Zealand & 17 & 18 & 19 & 19 & 21 & 21 & 20 & 19 & 17 \\
\hline Ireland & 18 & 19 & 21 & 21 & 23 & 23 & 21 & 20 & 18 \\
\hline Saudi Arabia & 29 & 40 & 37 & 38 & 30 & 45 & 36 & 33 & 19 \\
\hline Brazil & 19 & 17 & 15 & 16 & 16 & 17 & 16 & 15 & 20 \\
\hline Russian Federation & 23 & 23 & 22 & 22 & 19 & 18 & 18 & 18 & 21 \\
\hline Argentina & 20 & 21 & 20 & 20 & 22 & 22 & 22 & 21 & 22 \\
\hline Israel & 22 & 27 & 28 & 27 & 24 & 26 & 24 & 22 & 23 \\
\hline Portugal & 21 & 24 & 24 & 23 & 26 & 28 & 26 & 23 & 24 \\
\hline Iceland & 67 & 66 & 68 & 69 & 63 & 53 & 47 & 34 & 25 \\
\hline Rwanda & 49 & 46 & 31 & 39 & 36 & 31 & 33 & 30 & 26 \\
\hline Chile & 24 & 26 & 25 & 25 & 29 & 27 & 27 & 26 & 27 \\
\hline Ethiopia & 71 & 22 & 36 & 34 & 39 & 35 & 28 & 25 & 28 \\
\hline Mexico & 36 & 34 & 34 & 28 & 35 & 34 & 29 & 28 & 29 \\
\hline Senegal & 38 & 33 & 32 & 30 & 27 & 24 & 23 & 24 & 30 \\
\hline Uruguay & 27 & 29 & 27 & 24 & 28 & 32 & 31 & 31 & 31 \\
\hline Czechia & 33 & 28 & 38 & 31 & 32 & 33 & 32 & 32 & 32 \\
\hline South Africa & 28 & 32 & 33 & 35 & 38 & 40 & 39 & 47 & 33 \\
\hline Ghana & 31 & 61 & 29 & 40 & 34 & 36 & 40 & 35 & 34 \\
\hline Malta & 32 & 37 & 49 & 43 & 53 & 39 & 38 & 36 & 35 \\
\hline Zambia & 43 & 48 & 45 & 51 & 50 & 49 & 48 & 39 & 36 \\
\hline Togo & 47 & 35 & 30 & 32 & 25 & 30 & 30 & 37 & 37 \\
\hline Philippines & 25 & 31 & 26 & 29 & 31 & 37 & 35 & 27 & 38 \\
\hline Peru & 57 & 53 & 52 & 54 & 43 & 44 & 43 & 40 & 39 \\
\hline United Republic of Tanzania & 34 & 45 & 39 & 33 & 41 & 42 & 34 & 29 & 40 \\
\hline Indonesia & 81 & 83 & 77 & 77 & 77 & 67 & 60 & 59 & 41 \\
\hline Malawi & 40 & 38 & 23 & 41 & 40 & 29 & 42 & 41 & 42 \\
\hline
\end{tabular}


Table 24 (continued)

\begin{tabular}{|c|c|c|c|c|c|c|c|c|c|}
\hline Country & 2010 & 2011 & 2012 & 2013 & 2014 & 2015 & 2016 & 2017 & 2018 \\
\hline Poland & 26 & 30 & 35 & 37 & 42 & 41 & 45 & 38 & 43 \\
\hline Costa Rica & 64 & 41 & 41 & 49 & 48 & 50 & 51 & 42 & 44 \\
\hline Qatar & 39 & 36 & 48 & 36 & 37 & 38 & 46 & 48 & 45 \\
\hline Belarus & 52 & 57 & 55 & 57 & 79 & 56 & 54 & 46 & 46 \\
\hline Romania & 54 & 52 & 56 & 52 & 52 & 54 & 55 & 52 & 47 \\
\hline Malaysia & 59 & 59 & 64 & 64 & 75 & 79 & 76 & 72 & 48 \\
\hline Lesotho & 51 & 44 & 40 & 50 & 49 & 63 & 52 & 50 & 49 \\
\hline Lithuania & 53 & 54 & 63 & 58 & 57 & 64 & 61 & 55 & 50 \\
\hline India & 30 & 25 & 44 & 26 & 33 & 43 & 44 & 43 & 51 \\
\hline Mozambique & 41 & 43 & 46 & 44 & 46 & 52 & 50 & 45 & 52 \\
\hline Thailand & 48 & 47 & 51 & 45 & 47 & 51 & 53 & 53 & 53 \\
\hline Paraguay & 61 & 58 & 58 & 67 & 54 & 60 & 63 & 61 & 54 \\
\hline Hungary & 62 & 62 & 66 & 66 & 76 & 69 & 75 & 64 & 55 \\
\hline Burkina Faso & 68 & 56 & 65 & 47 & 56 & 47 & 41 & 51 & 56 \\
\hline Latvia & 65 & 63 & 67 & 60 & 67 & 72 & 70 & 58 & 57 \\
\hline Panama & 44 & 42 & 43 & 46 & 45 & 48 & 49 & 49 & 58 \\
\hline Nepal & 35 & 20 & 73 & 65 & 64 & 46 & 66 & 60 & 59 \\
\hline Guatemala & 73 & 51 & 50 & 56 & 51 & 57 & 64 & 57 & 60 \\
\hline Slovakia & 55 & 55 & 59 & 59 & 59 & 61 & 62 & 63 & 61 \\
\hline Estonia & 69 & 74 & 75 & 82 & 81 & 76 & 69 & 62 & 62 \\
\hline Kenya & 37 & 39 & 47 & 53 & 58 & 59 & 59 & 68 & 63 \\
\hline El Salvador & 66 & 72 & 62 & 75 & 65 & 62 & 67 & 65 & 64 \\
\hline Colombia & 60 & 67 & 70 & 79 & 87 & 83 & 79 & 75 & 65 \\
\hline Slovenia & 50 & 49 & 61 & 63 & 74 & 78 & 73 & 70 & 66 \\
\hline Ukraine & 58 & 60 & 53 & 42 & 44 & 55 & 71 & 69 & 67 \\
\hline Cyprus & 63 & 65 & 82 & 84 & 85 & 81 & 78 & 71 & 68 \\
\hline Cameroon & 92 & 71 & 106 & 109 & 89 & 77 & 87 & 81 & 69 \\
\hline Bangladesh & 42 & 50 & 42 & 48 & 60 & 65 & 68 & 54 & 70 \\
\hline Uganda & 56 & 64 & 57 & 55 & 55 & 58 & 56 & 44 & 71 \\
\hline Liberia & NA & NA & 69 & 62 & 73 & NA & NA & 66 & 72 \\
\hline Sierra Leone & 100 & 92 & 92 & 93 & 62 & 68 & 57 & 67 & 73 \\
\hline Serbia & 70 & 68 & 71 & 70 & 80 & 82 & 77 & 76 & 74 \\
\hline Tunisia & 75 & 76 & 81 & 81 & 84 & 84 & 80 & 79 & 75 \\
\hline Djibouti & 45 & 70 & 60 & 61 & 72 & 70 & 74 & 78 & 76 \\
\hline Croatia & 74 & 80 & 86 & 87 & 93 & 91 & 88 & 84 & 77 \\
\hline Eswatini & 96 & 95 & 76 & 86 & 98 & 92 & 83 & 80 & 78 \\
\hline Benin & 93 & 75 & 72 & 76 & 78 & 73 & 72 & 74 & 79 \\
\hline Niger & 98 & 96 & 90 & 73 & 69 & 66 & 58 & 56 & 80 \\
\hline Republic of Moldova & 103 & 87 & 79 & 78 & 82 & 87 & 85 & 83 & 81 \\
\hline Ecuador & 78 & 78 & 88 & 88 & 94 & 98 & 91 & 89 & 82 \\
\hline Nicaragua & 85 & 82 & 83 & 71 & 71 & 74 & 82 & 82 & 83 \\
\hline Madagascar & 76 & 79 & 84 & 74 & 68 & 71 & 65 & 77 & 84 \\
\hline
\end{tabular}


Table 24 (continued)

\begin{tabular}{|c|c|c|c|c|c|c|c|c|c|}
\hline Country & 2010 & 2011 & 2012 & 2013 & 2014 & 2015 & 2016 & 2017 & 2018 \\
\hline Bulgaria & 77 & 84 & 78 & 80 & 91 & 94 & 86 & 90 & 85 \\
\hline Fiji & 106 & 103 & 102 & 113 & 103 & 114 & 112 & 88 & 86 \\
\hline Cuba & 90 & 89 & 99 & 94 & 92 & 85 & 81 & 85 & 87 \\
\hline Pakistan & 82 & 69 & 54 & 68 & 61 & 25 & 37 & 73 & 88 \\
\hline Honduras & NA & NA & NA & 85 & 70 & 86 & NA & NA & 89 \\
\hline Mauritius & 86 & 85 & 94 & 102 & 100 & 102 & 110 & 94 & 90 \\
\hline Timor-Leste & 72 & 73 & 74 & 83 & 90 & 90 & 90 & 87 & 91 \\
\hline Lebanon & 115 & 99 & 101 & 101 & 102 & 100 & 102 & 96 & 92 \\
\hline Armenia & 105 & 91 & 91 & 95 & 95 & 95 & 94 & 93 & 93 \\
\hline Kyrgyzstan & 87 & 77 & 80 & 90 & 99 & 101 & 98 & 100 & 94 \\
\hline Kazakhstan & 79 & 88 & 93 & 96 & 97 & 99 & 97 & 99 & 95 \\
\hline Central African Republic & 84 & 81 & 89 & 72 & 66 & 88 & 103 & 91 & 96 \\
\hline Mauritania & 97 & 101 & 112 & 110 & 108 & 106 & 100 & 97 & 97 \\
\hline Mali & 94 & 90 & 103 & 91 & 88 & 75 & 104 & 98 & 98 \\
\hline Cambodia & 99 & 102 & 95 & 100 & 96 & 97 & 92 & 95 & 99 \\
\hline Chad & 112 & 107 & 108 & 108 & 106 & 89 & 95 & 105 & 100 \\
\hline Georgia & 119 & 108 & 111 & 112 & 113 & 104 & 106 & 102 & 101 \\
\hline Gambia & 80 & 97 & 87 & 92 & 83 & 96 & 84 & 92 & 102 \\
\hline Bahrain & 83 & 86 & 96 & 104 & 104 & 112 & 99 & 111 & 103 \\
\hline Azerbaijan & 88 & 94 & 97 & 103 & 105 & 105 & 109 & 104 & 104 \\
\hline Burundi & 109 & 109 & 100 & 99 & 107 & 109 & 101 & 103 & 105 \\
\hline Namibia & 95 & 106 & 109 & 105 & 109 & 108 & 114 & 108 & 106 \\
\hline Tajikistan & 101 & 100 & 105 & 107 & 114 & 113 & 113 & 109 & 107 \\
\hline Oman & 91 & 98 & 98 & 98 & 101 & 103 & 105 & 101 & 108 \\
\hline Congo & 113 & 113 & 115 & 115 & 110 & 110 & 107 & 106 & 109 \\
\hline Mongolia & 108 & 111 & 104 & 106 & 112 & 111 & 111 & 107 & 110 \\
\hline Belize & 104 & 105 & 110 & 114 & 117 & 107 & 116 & 114 & 111 \\
\hline Guyana & 114 & 116 & 117 & 118 & 120 & 119 & 120 & 113 & 112 \\
\hline Albania & 102 & 104 & 107 & 111 & 116 & 116 & 115 & 112 & 113 \\
\hline Barbados & 111 & 110 & 113 & 117 & 115 & 115 & 117 & 115 & 114 \\
\hline Sri Lanka & 117 & 114 & 114 & 119 & 119 & 118 & 118 & 117 & 115 \\
\hline Afghanistan & 110 & 112 & 116 & 116 & 118 & 117 & 119 & 116 & 116 \\
\hline Viet Nam & 116 & 117 & 119 & 122 & 123 & 122 & 122 & 119 & 117 \\
\hline Saint Vincent and the Grenadines & 118 & 115 & 118 & 121 & 122 & 121 & 121 & 118 & 118 \\
\hline Maldives & 121 & 120 & 122 & 125 & 126 & 123 & 124 & 121 & 119 \\
\hline Saint Lucia & 123 & 121 & 123 & 124 & 125 & 125 & 126 & 123 & 120 \\
\hline Lao People's Democratic Republic & 120 & 118 & 120 & 123 & 124 & 124 & 125 & 122 & 121 \\
\hline Bhutan & 122 & 119 & 121 & 126 & 127 & 126 & 127 & 124 & 122 \\
\hline Myanmar & NA & 122 & NA & NA & NA & NA & NA & 125 & 123 \\
\hline Iran (Islamic Republic of) & 46 & 93 & 85 & 89 & 86 & 80 & 89 & 86 & NA \\
\hline Democratic Republic of the Congo & 89 & NA & NA & 97 & 111 & 93 & 108 & 110 & NA \\
\hline Uzbekistan & NA & NA & NA & 120 & 121 & 120 & 123 & 120 & NA \\
\hline
\end{tabular}


Table 24 (continued)

\begin{tabular}{llllllllll}
\hline Country & 2010 & 2011 & 2012 & 2013 & 2014 & 2015 & 2016 & 2017 & 2018 \\
\hline Japan & NA & NA & NA & 3 & 4 & 4 & 4 & NA & NA \\
Republic of Korea & NA & NA & NA & NA & NA & NA & 25 & NA & NA \\
Brunei Darussalam & NA & NA & NA & NA & NA & NA & 93 & NA & NA \\
Samoa & NA & NA & NA & NA & NA & NA & 96 & NA & NA \\
Luxembourg & NA & NA & 16 & NA & 17 & 16 & NA & NA & NA \\
\hline
\end{tabular}

However, as we discussed earlier, we use a population-based weighed score of indices to construct score for this issue from the perspective of global justice. As a result, the highest score indicates not the best performance at the individual right level, but rather means that the country has made a sufficient number of women and children far better off than the world average.

\section{Global Justice Indices: Main Results}

In this section, we report each country's contribution to global justice from 2010 to 2018. Data availability is one of the most serious challenges facing this study. For example, because of the lack of data on energy consumption and electricity production, the issue of climate change in this report only covers 75 countries in 2018. Similarly, data on the issue areas of education and anti-poverty only cover 139 and 152 countries in 2018, respectively. Most of the countries which are not covered in these three issues are in Asia and Africa. Thus, we first provide a global justice index that excludes climate change and anti-poverty over 2010-2018 (Table 24); second, a global justice index over 2010-2018 that excludes climate change and education is reported (Table 25). Finally, we provide a global justice index of all ten issues over 2010-2018 (Table 26).

Table 24 shows the global justice index excluding both climate change and antipoverty. In 2018, as shown in the table, the United States, Germany, the United Kingdom, Sweden,Norway, China, Canada, Belgium, Italy and Finland rank as the top 10 in the global justice index that excludes climate change and anti-poverty. All of the top ten countries except China are are high-income and located in North America and Europe. Most countries which perform badly in global justice come from Africa, Asia and the Caribbean, including Myanmar, Bhutan, Lao People's Democratic Republic, Saint Lucia, Maldives. Afghanistan, and Vietnam, Congo, Sri Lanka and Barbados. Figure 23 vividly shows the distribution of the rank of global justice (except for climate change and anti-poverty) in 2018. As the figure shows, North America, Europe and oceania rank highly, while Africa and Asia (especially South Asia and West Asia) rank low.

Table 25 shows the global justice index except for both climate change and education. Similarly to Table 24, Table 25 shows that, in 2018, the United States, Germany, the United Kingdom, China, Sweden, Fracen, Canada, Italy, Belgium 
Table 25 Global justice index (except for both climate change and education)

\begin{tabular}{|c|c|c|c|c|c|c|c|c|c|}
\hline Country & 2010 & 2011 & 2012 & 2013 & 2014 & 2015 & 2016 & 2017 & 2018 \\
\hline United States of America & 1 & 1 & 1 & 1 & 1 & 1 & 1 & 1 & 1 \\
\hline Germany & 3 & 3 & 3 & 4 & 4 & 2 & 2 & 2 & 2 \\
\hline $\begin{array}{l}\text { United Kingdom of Great Britain } \\
\text { and Northern Ireland }\end{array}$ & 2 & 2 & 2 & 2 & 2 & 3 & 3 & 4 & 3 \\
\hline China & 5 & 4 & 4 & 5 & 5 & 5 & 5 & 3 & 4 \\
\hline Sweden & 7 & 6 & 6 & 7 & 8 & 8 & 8 & 7 & 5 \\
\hline France & 4 & 5 & 5 & 6 & 6 & 6 & 6 & 5 & 6 \\
\hline Canada & 8 & 8 & 8 & 9 & 9 & 9 & 9 & 8 & 7 \\
\hline Italy & 6 & 7 & 7 & 8 & 7 & 7 & 7 & 6 & 8 \\
\hline Belgium & 15 & 12 & 12 & 11 & 13 & 11 & 12 & 10 & 9 \\
\hline Norway & 9 & 10 & 9 & 10 & 10 & 10 & 10 & 9 & 10 \\
\hline Finland & 11 & 11 & 11 & 13 & 11 & 13 & 13 & 12 & 11 \\
\hline Switzerland & 12 & 13 & 14 & 14 & 16 & 17 & 18 & 13 & 12 \\
\hline Spain & 10 & 9 & 10 & 12 & 12 & 12 & 11 & 11 & 13 \\
\hline Denmark & 14 & 15 & 16 & 15 & 18 & 16 & 15 & 15 & 14 \\
\hline Netherlands & 13 & 14 & 15 & 17 & 17 & 14 & 17 & 17 & 15 \\
\hline Austria & 16 & 18 & 17 & 18 & 19 & 19 & 19 & 18 & 16 \\
\hline Luxembourg & 18 & 20 & 19 & 22 & 21 & 21 & 20 & 19 & 17 \\
\hline Russian Federation & 23 & 21 & 21 & 20 & 15 & 15 & 14 & 14 & 18 \\
\hline Australia & 17 & 17 & 18 & 19 & 22 & 22 & 21 & 20 & 19 \\
\hline Greece & 21 & 19 & 20 & 21 & 20 & 20 & 22 & 21 & 20 \\
\hline Ireland & 19 & 22 & 22 & 23 & 23 & 24 & 24 & 22 & 21 \\
\hline Brazil & 20 & 16 & 13 & 16 & 14 & 18 & 16 & 16 & 22 \\
\hline Portugal & 24 & 25 & 25 & 27 & 25 & 26 & 25 & 24 & 23 \\
\hline Turkey & 22 & 23 & 23 & 24 & 24 & 23 & 23 & 23 & 24 \\
\hline Republic of Korea & 30 & 33 & 31 & 33 & 30 & 27 & 27 & 26 & 25 \\
\hline Israel & 25 & 32 & 30 & 32 & 29 & 30 & 30 & 29 & 26 \\
\hline Chile & 26 & 26 & 27 & 26 & 26 & 25 & 26 & 25 & 27 \\
\hline Uruguay & 28 & 30 & 26 & 25 & 27 & 29 & 28 & 27 & 28 \\
\hline Czechia & 29 & 27 & 29 & 28 & 28 & 28 & 29 & 28 & 29 \\
\hline Belarus & 33 & 37 & 36 & 38 & 55 & 39 & 33 & 32 & 30 \\
\hline Ethiopia & 89 & 29 & 47 & 39 & 48 & 45 & 34 & 31 & 31 \\
\hline Rwanda & 56 & 61 & 35 & 44 & 43 & 38 & 43 & 43 & 32 \\
\hline Mexico & 45 & 38 & 42 & 37 & 53 & 43 & 36 & 36 & 33 \\
\hline Poland & 27 & 28 & 28 & 30 & 32 & 33 & 31 & 30 & 34 \\
\hline Malta & 31 & 35 & 41 & 34 & 49 & 36 & 35 & 33 & 35 \\
\hline Zambia & 36 & 46 & 39 & 48 & 45 & 47 & 42 & 38 & 36 \\
\hline Malaysia & 49 & 52 & 53 & 54 & 56 & 60 & 61 & 59 & 37 \\
\hline Peru & 52 & 56 & 49 & 52 & 38 & 42 & 38 & 37 & 38 \\
\hline Costa Rica & 55 & 36 & 33 & 40 & 39 & 46 & 44 & 40 & 39 \\
\hline India & 32 & 24 & 37 & 31 & 33 & 40 & 37 & 35 & 40 \\
\hline Iceland & 84 & 82 & 88 & 89 & 87 & 77 & 76 & 68 & 41 \\
\hline Lithuania & 40 & 47 & 51 & 51 & 44 & 51 & 47 & 44 & 42 \\
\hline
\end{tabular}


Table 25 (continued)

\begin{tabular}{|c|c|c|c|c|c|c|c|c|c|}
\hline Country & 2010 & 2011 & 2012 & 2013 & 2014 & 2015 & 2016 & 2017 & 2018 \\
\hline Thailand & 43 & 39 & 46 & 35 & 35 & 35 & 39 & 39 & 43 \\
\hline Romania & 54 & 59 & 57 & 53 & 50 & 52 & 46 & 45 & 44 \\
\hline Hungary & 47 & 49 & 54 & 57 & 57 & 53 & 62 & 52 & 45 \\
\hline Paraguay & 53 & 55 & 50 & 61 & 40 & 50 & 49 & 51 & 46 \\
\hline Ghana & 58 & 87 & 45 & 55 & 51 & 49 & 57 & 50 & 47 \\
\hline South Africa & 44 & 41 & 44 & 45 & 47 & 54 & 52 & 64 & 48 \\
\hline Senegal & 57 & 48 & 48 & 46 & 36 & 34 & 32 & 34 & 49 \\
\hline Latvia & 50 & 53 & 60 & 56 & 58 & 58 & 56 & 47 & 50 \\
\hline Slovakia & 37 & 40 & 40 & 50 & 42 & 48 & 45 & 49 & 51 \\
\hline Malawi & 42 & 44 & 24 & 43 & 41 & 31 & 48 & 48 & 52 \\
\hline Panama & 35 & 34 & 34 & 36 & 37 & 41 & 40 & 41 & 53 \\
\hline Togo & 65 & 43 & 38 & 41 & 34 & 37 & 41 & 54 & 54 \\
\hline Ukraine & 38 & 42 & 32 & 29 & 31 & 44 & 54 & 53 & 55 \\
\hline Philippines & 48 & 50 & 43 & 49 & 46 & 57 & 55 & 42 & 56 \\
\hline Serbia & 59 & 58 & 62 & 63 & 60 & 59 & 58 & 60 & 57 \\
\hline Egypt & 51 & 54 & 69 & 70 & 72 & 79 & 68 & 57 & 58 \\
\hline Republic of North Macedonia & 61 & 63 & 63 & 60 & 59 & 61 & 63 & 62 & 59 \\
\hline Indonesia & 97 & 101 & 105 & 100 & 103 & 97 & 75 & 73 & 60 \\
\hline United Republic of Tanzania & 46 & 62 & 59 & 42 & 52 & 56 & 50 & 46 & 61 \\
\hline Lesotho & 63 & 57 & 56 & 62 & 63 & 72 & 60 & 58 & 62 \\
\hline Estonia & 68 & 68 & 72 & 73 & 71 & 68 & 64 & 61 & 63 \\
\hline Slovenia & 41 & 45 & 52 & 58 & 61 & 64 & 66 & 63 & 64 \\
\hline Mozambique & 39 & 51 & 55 & 47 & 54 & 55 & 53 & 55 & 65 \\
\hline Croatia & 60 & 66 & 64 & 67 & 69 & 69 & 71 & 67 & 66 \\
\hline El Salvador & 75 & 79 & 68 & 82 & 70 & 63 & 67 & 66 & 67 \\
\hline Colombia & 72 & 71 & 78 & 84 & 80 & 83 & 80 & 77 & 68 \\
\hline Republic of Moldova & 98 & 91 & 79 & 71 & 67 & 73 & 83 & 70 & 69 \\
\hline Guatemala & 81 & 65 & 61 & 68 & 62 & 66 & 70 & 65 & 70 \\
\hline Tunisia & 78 & 75 & 75 & 79 & 74 & 80 & 78 & 75 & 71 \\
\hline Bulgaria & 69 & 74 & 65 & 66 & 75 & 81 & 74 & 74 & 72 \\
\hline Cyprus & 73 & 69 & 76 & 83 & 76 & 74 & 77 & 71 & 73 \\
\hline Bolivia (Plurinational State of) & 62 & 60 & 58 & 59 & 66 & 78 & 72 & 81 & 74 \\
\hline Algeria & NA & NA & NA & 76 & 78 & 75 & 79 & 78 & 75 \\
\hline Azerbaijan & 64 & 70 & 71 & 72 & 77 & 76 & 82 & 76 & 76 \\
\hline Morocco & 70 & 92 & 84 & 77 & 79 & 70 & 81 & 79 & 77 \\
\hline Ecuador & 80 & 80 & 82 & 88 & 88 & 94 & 90 & 87 & 78 \\
\hline Lebanon & NA & NA & NA & 86 & 84 & 82 & 89 & 84 & 79 \\
\hline Mauritius & 83 & 83 & 87 & 93 & 91 & 92 & 95 & 85 & 80 \\
\hline Kazakhstan & 77 & 77 & 80 & 74 & 81 & 85 & 87 & 86 & 81 \\
\hline Burkina Faso & 85 & 78 & 86 & 65 & 83 & 67 & 59 & 72 & 82 \\
\hline Uganda & 66 & 73 & 66 & 64 & 64 & 65 & 65 & 56 & 83 \\
\hline Madagascar & 82 & 85 & 83 & 80 & 73 & 71 & 69 & 83 & 84 \\
\hline
\end{tabular}


Table 25 (continued)

\begin{tabular}{|c|c|c|c|c|c|c|c|c|c|}
\hline Country & 2010 & 2011 & 2012 & 2013 & 2014 & 2015 & 2016 & 2017 & 2018 \\
\hline Cameroon & 101 & 90 & 113 & 116 & 98 & 91 & 99 & 96 & 85 \\
\hline Nepal & 71 & 31 & 103 & 101 & 99 & 84 & 96 & 93 & 86 \\
\hline Botswana & 92 & 97 & 94 & 106 & 107 & 109 & 108 & 97 & 87 \\
\hline Liberia & 90 & 76 & 89 & 87 & 93 & 100 & 91 & 88 & 88 \\
\hline Kenya & 67 & 67 & 77 & 85 & 90 & 88 & 88 & 95 & 89 \\
\hline Honduras & 87 & 86 & 90 & 95 & 85 & 95 & 93 & 89 & 90 \\
\hline Benin & 100 & 89 & 85 & 90 & 89 & 86 & 86 & 91 & 91 \\
\hline Sierra Leone & 108 & 102 & 107 & 111 & 94 & 90 & 84 & 92 & 92 \\
\hline Fiji & 113 & 113 & 109 & 122 & 112 & 119 & 118 & 103 & 93 \\
\hline Armenia & 119 & 114 & 108 & 108 & 109 & 105 & 103 & 98 & 94 \\
\hline Eswatini & 104 & 108 & 93 & 99 & 110 & 108 & 100 & 100 & 95 \\
\hline Samoa & 96 & 96 & 102 & 107 & 105 & 103 & 97 & 99 & 96 \\
\hline Bangladesh & 74 & 81 & 74 & 75 & 92 & 93 & 92 & 82 & 97 \\
\hline Dominican Republic & 88 & 95 & 96 & 103 & 104 & 101 & 94 & 101 & 98 \\
\hline Central African Republic & 91 & 94 & 92 & 78 & 68 & 89 & 102 & 94 & 99 \\
\hline Pakistan & 95 & 93 & 73 & 92 & 82 & 32 & 51 & 90 & 100 \\
\hline Nicaragua & 99 & 100 & 98 & 97 & 96 & 98 & 98 & 102 & 101 \\
\hline Niger & 103 & 107 & 104 & 96 & 95 & 87 & 85 & 80 & 102 \\
\hline Burundi & 106 & 110 & 97 & 98 & 108 & 107 & 101 & 104 & 103 \\
\hline Georgia & 122 & 120 & 117 & 119 & 117 & 111 & 109 & 109 & 104 \\
\hline Mongolia & 109 & 115 & 100 & 102 & 102 & 104 & 107 & 105 & 105 \\
\hline Chad & 115 & 117 & 115 & 114 & 114 & 102 & 106 & 111 & 106 \\
\hline Namibia & 107 & 116 & 116 & 110 & 111 & 113 & 112 & 110 & 107 \\
\hline Albania & 102 & 109 & 110 & 115 & 118 & 117 & 115 & 114 & 108 \\
\hline Papua New Guinea & NA & 105 & 99 & 112 & 116 & 112 & 113 & 106 & 109 \\
\hline Democratic Republic of the Congo & 86 & 99 & 91 & 94 & 106 & 96 & 105 & 107 & 110 \\
\hline Tajikistan & 114 & 112 & 114 & 117 & 120 & 118 & 119 & 116 & 111 \\
\hline Mali & 105 & 106 & 112 & 104 & 100 & 99 & 114 & 113 & 112 \\
\hline Mauritania & 112 & 118 & 119 & 121 & 119 & 120 & 116 & 118 & 113 \\
\hline Timor-Leste & 94 & 98 & 101 & 109 & 113 & 116 & 117 & 112 & 114 \\
\hline Gambia & 93 & 104 & 95 & 105 & 97 & 110 & 104 & 108 & 115 \\
\hline Congo & 116 & 122 & 120 & 120 & 115 & 114 & 111 & 117 & 116 \\
\hline Viet Nam & 110 & 121 & 121 & 123 & 122 & 122 & 120 & 119 & 117 \\
\hline Sri Lanka & 121 & 124 & 122 & 125 & 123 & 123 & 122 & 121 & 118 \\
\hline Kyrgyzstan & 111 & 103 & 111 & 118 & 121 & 121 & 121 & 122 & 119 \\
\hline Nigeria & 79 & 88 & 81 & 91 & 101 & 115 & 110 & 115 & 120 \\
\hline Tonga & 120 & 123 & 123 & 126 & 125 & 124 & 123 & 123 & 121 \\
\hline Yemen & 118 & 119 & 118 & 124 & 124 & 125 & 124 & 120 & 122 \\
\hline Maldives & 124 & 126 & 125 & 128 & 126 & 126 & 125 & 124 & 123 \\
\hline Bhutan & 125 & 127 & 126 & 129 & 128 & 128 & 127 & 125 & 124 \\
\hline Uzbekistan & 123 & 125 & 124 & 127 & 127 & 127 & 126 & 126 & 125 \\
\hline Lao People's Democratic Republic & 126 & 128 & 127 & 130 & 129 & 129 & 128 & 127 & 126 \\
\hline
\end{tabular}


Table 25 (continued)

\begin{tabular}{llllllllll}
\hline Country & 2010 & 2011 & 2012 & 2013 & 2014 & 2015 & 2016 & 2017 & 2018 \\
\hline Myanmar & NA & NA & NA & NA & NA & NA & 129 & 128 & 127 \\
Iran (Islamic Republic of) & 34 & 84 & 67 & 69 & 65 & 62 & 73 & 69 & NA \\
Japan & NA & NA & NA & 3 & 3 & 4 & 4 & NA & NA \\
Angola & 117 & 111 & NA & NA & NA & 106 & NA & NA & NA \\
Venezuela (Bolivarian Republic of) & 76 & 72 & 70 & 81 & 86 & NA & NA & NA & NA \\
Zimbabwe & NA & NA & 106 & 113 & NA & NA & NA & NA & NA \\
Gabon & NA & 64 & NA & NA & NA & NA & NA & NA & NA \\
\hline
\end{tabular}

and Norway rank among the top 10 in the global justice index (excluding chimate change and education). Myanmar, Lao People's Democratic Republic, Uzbekistan, Bhutan, Maldives, Yemen, Tonga, Nigeria, Kyrgyzstan and Sri Lanka, all of which come from Africa, Asia and Oceania, are the bottom ten countries in the global justice index. Figure 24 clearly shows the indistribution of the rank in global justice (excluding climate change and education) in 2018. Although the two figures exclude different issues, Fig. 24 shows the same pattern as Fig. 23.

Table 26 shows the global justice index including all ten issues. In 2018, as shown in Table 26, the United States, Germany, the United Kingdom, China, Sweden, Norway, Canada, Belgium, Finland and Italy ranked the top ten in the global justice index that includes all issues. Although Table 26 only covers 52 countries in 2018, the results are very similar to Tables 24 and 25, suggesting the robustness of global justice index. In addition, Fig. 25 also illustrates that the lowest-ranked countries come from Africa, Asia, and Latin America, and that, apart from China, the highest-ranked countries come from Europe and North America, affirming that the rank of global justice index highly correlates with economic development.

We also present the scores in the global justice index (including all ten issues) across continents from 2010 to 2018 in Fig. 26. The figure shows that North America, Europe and Oceania ranked highly while Latin America, Asia and Africa ranked low from 2010 to 2018, and that the pattern has been stable over the years, suggesting the robustness of our measurement. Even so, we remind readers of the variation within continents. For example, although Asia as a whole ranked low during 2010-2018, two coutries from Asia,China and Japan, performed well: China ranked 4th in 2018 and Japan ranked 6th in 2016. And vice versa, although Europe as a whole ranked highly, Bulgaria and Ukraine, both of which are in Europe, only ranked 45th and 42nd out of 52 countries in 2018.

\section{Conclusion}

The Global Justice Index is a multiyear research project to conceptualize and measure each country's contribution to global justice. In this year's Global Justice Index, we kept unchanged the theoretical framework of last year and made a few modifications to refine our measurements. According to the two major principles of 
Table 26 Global justice index (including all ten issues)

\begin{tabular}{|c|c|c|c|c|c|c|c|c|c|}
\hline Country & 2010 & 2011 & 2012 & 2013 & 2014 & 2015 & 2016 & 2017 & 2018 \\
\hline United States of America & 1 & 1 & 1 & 1 & 1 & 1 & 1 & 1 & 1 \\
\hline Germany & 3 & 3 & 3 & 5 & 3 & 3 & 2 & 2 & 2 \\
\hline $\begin{array}{l}\text { United Kingdom of Great } \\
\text { Britain and Northern } \\
\text { Ireland }\end{array}$ & 2 & 2 & 2 & 2 & 2 & 2 & 3 & 4 & 3 \\
\hline China & 4 & 4 & 4 & 4 & 4 & 4 & 4 & 3 & 4 \\
\hline Sweden & 5 & 5 & 5 & 6 & 6 & 6 & 6 & 5 & 5 \\
\hline Norway & 6 & 6 & 6 & 7 & 7 & 7 & 7 & 6 & 6 \\
\hline Canada & 7 & 7 & 7 & 8 & 9 & 9 & 8 & 7 & 7 \\
\hline Belgium & 14 & 13 & 12 & 13 & 13 & 13 & 13 & 12 & 8 \\
\hline Finland & 11 & 10 & 9 & 10 & 10 & 10 & 11 & 9 & 9 \\
\hline Italy & 8 & 8 & 8 & 9 & 8 & 8 & 9 & 8 & 10 \\
\hline Switzerland & 12 & 11 & 10 & 12 & 12 & 12 & 12 & 11 & 11 \\
\hline Denmark & 10 & 12 & 14 & 11 & 11 & 11 & 10 & 10 & 12 \\
\hline Austria & 15 & 17 & 17 & 18 & 18 & 19 & 18 & 16 & 13 \\
\hline Netherlands & 13 & 14 & 15 & 15 & 16 & 14 & 15 & 15 & 14 \\
\hline Spain & 9 & 9 & 13 & 14 & 15 & 15 & 14 & 13 & 15 \\
\hline Australia & 16 & 15 & 16 & 17 & 20 & 20 & 19 & 18 & 16 \\
\hline Ireland & 17 & 18 & 20 & 20 & 21 & 21 & 20 & 19 & 17 \\
\hline Russian Federation & 20 & 19 & 19 & 19 & 17 & 16 & 17 & 17 & 18 \\
\hline Brazil & 18 & 16 & 11 & 16 & 14 & 17 & 16 & 14 & 19 \\
\hline Portugal & 19 & 20 & 21 & 21 & 22 & 22 & 22 & 20 & 20 \\
\hline Israel & 21 & 22 & 23 & 23 & 23 & 23 & 23 & 21 & 21 \\
\hline Iceland & 38 & 38 & 39 & 41 & 38 & 30 & 27 & 24 & 22 \\
\hline Chile & 22 & 21 & 22 & 22 & 24 & 24 & 24 & 22 & 23 \\
\hline Czechia & 24 & 23 & 25 & 24 & 25 & 25 & 25 & 23 & 24 \\
\hline Poland & 23 & 24 & 24 & 25 & 26 & 26 & 26 & 25 & 25 \\
\hline Mexico & 30 & 27 & 28 & 28 & 33 & 29 & 28 & 28 & 26 \\
\hline Belarus & 26 & 29 & 26 & 29 & 41 & 31 & 29 & 26 & 27 \\
\hline Malaysia & 32 & 32 & 34 & 37 & 39 & 40 & 40 & 38 & 28 \\
\hline Peru & 37 & 37 & 31 & 34 & 28 & 27 & 30 & 27 & 29 \\
\hline Lithuania & 28 & 31 & 35 & 31 & 31 & 33 & 33 & 29 & 30 \\
\hline Latvia & 35 & 33 & 36 & 32 & 35 & 35 & 35 & 30 & 31 \\
\hline Hungary & 33 & 34 & 37 & 39 & 40 & 37 & 41 & 36 & 32 \\
\hline Thailand & 29 & 30 & 32 & 27 & 29 & 28 & 31 & 31 & 33 \\
\hline Romania & 40 & 41 & 40 & 38 & 37 & 36 & 34 & 33 & 34 \\
\hline Slovakia & 27 & 28 & 29 & 33 & 30 & 32 & 32 & 34 & 35 \\
\hline Slovenia & 25 & 26 & 27 & 35 & 36 & 38 & 36 & 35 & 36 \\
\hline Estonia & 43 & 43 & 44 & 44 & 44 & 43 & 39 & 37 & 37 \\
\hline Cyprus & 34 & 35 & 41 & 42 & 43 & 42 & 43 & 39 & 38 \\
\hline South Africa & 39 & 39 & 38 & 40 & 42 & 44 & 42 & 43 & 39 \\
\hline Philippines & 41 & 36 & 33 & 36 & 34 & 41 & 38 & 32 & 40 \\
\hline Indonesia & 50 & 50 & 52 & 51 & 51 & 51 & 47 & 45 & 41 \\
\hline
\end{tabular}


Table 26 (continued)

\begin{tabular}{llllllllll}
\hline Country & 2010 & 2011 & 2012 & 2013 & 2014 & 2015 & 2016 & 2017 & 2018 \\
\hline Ukraine & 36 & 40 & 30 & 26 & 27 & 34 & 44 & 41 & 42 \\
Colombia & 44 & 42 & 45 & 45 & 46 & 46 & 46 & 42 & 43 \\
India & 42 & 25 & 42 & 30 & 32 & 39 & 37 & 40 & 44 \\
Bulgaria & 45 & 44 & 43 & 43 & 45 & 48 & 45 & 44 & 45 \\
Ecuador & 47 & 46 & 48 & 48 & 49 & 50 & 51 & 48 & 46 \\
Azerbaijan & 46 & 45 & 46 & 46 & 48 & 49 & 49 & 47 & 47 \\
Kazakhstan & 49 & 47 & 49 & 49 & 50 & 52 & 52 & 49 & 48 \\
Bangladesh & 48 & 49 & 50 & 50 & 52 & 53 & 53 & 50 & 49 \\
Viet Nam & 51 & 52 & 54 & 53 & 55 & 55 & 55 & 52 & 50 \\
Pakistan & 52 & 51 & 51 & 52 & 53 & 45 & 50 & 51 & 51 \\
Sri Lanka & 53 & 53 & 53 & 54 & 54 & 54 & 54 & 53 & 52 \\
Iran (Islamic Republic of) & 31 & 48 & 47 & 47 & 47 & 47 & 48 & 46 & NA \\
Uzbekistan & NA & NA & NA & 55 & 56 & 56 & 56 & 54 & NA \\
Japan & NA & NA & NA & 3 & 5 & 5 & 5 & NA & NA \\
Republic of Korea & NA & NA & NA & NA & NA & NA & 21 & NA & NA \\
Luxembourg & NA & NA & 18 & NA & 19 & 18 & NA & NA & NA \\
\hline
\end{tabular}

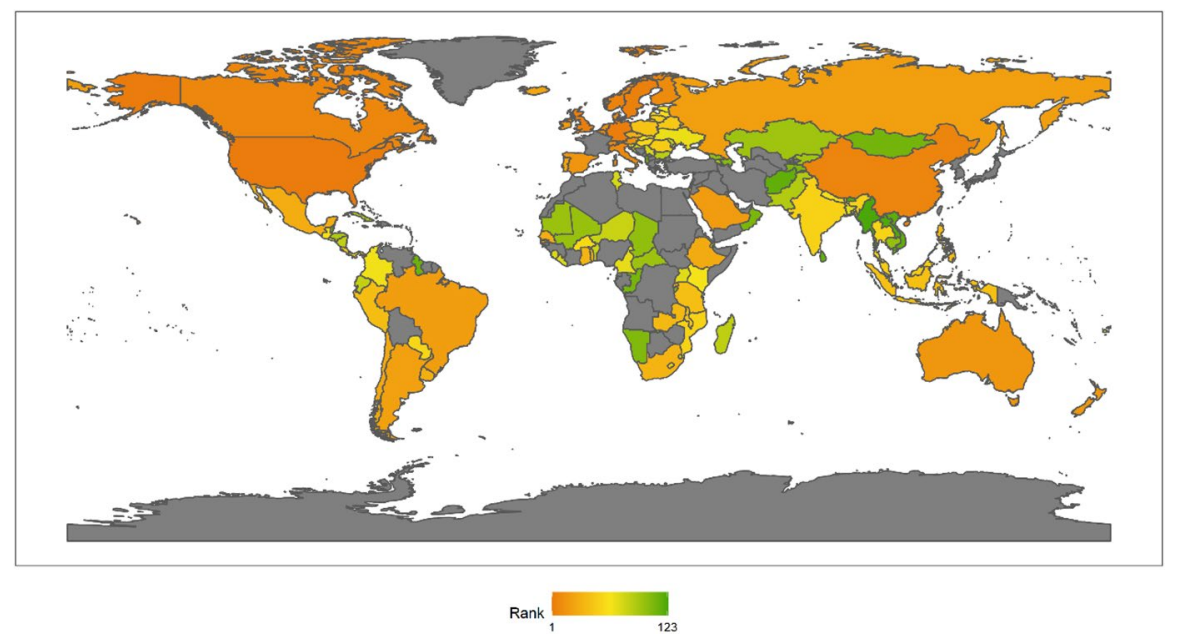

Fig. 232018 Index ranking of global justice (except for climate change and anti-poverty)

CBDR-RC and CDDR, which was the synthesis of rights based, goods based, and virtue based approaches embedded in the historical discussion of global justice, we added a brand new issue area into our measurement and ended up with a ten-issue index system: (1) climate change (global warming), (2) peacekeeping, (3) humanitarian aid, (4) terrorism and armed conflicts, (5) cross-national criminal police 


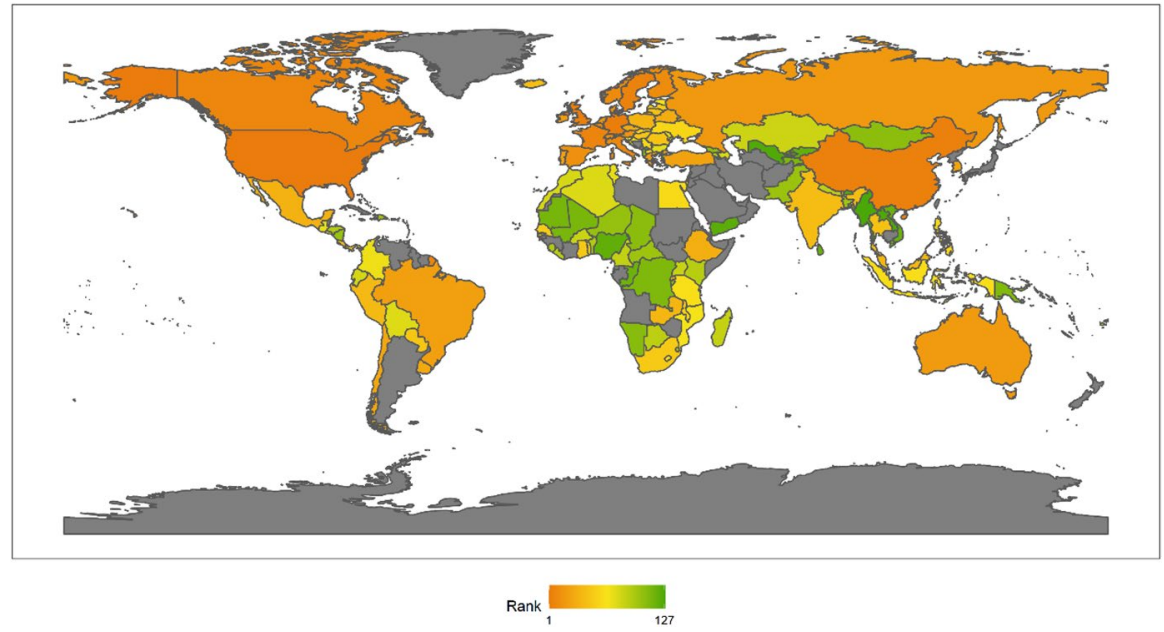

Fig. 242018 Index ranking of global justice (except for climate change and education)

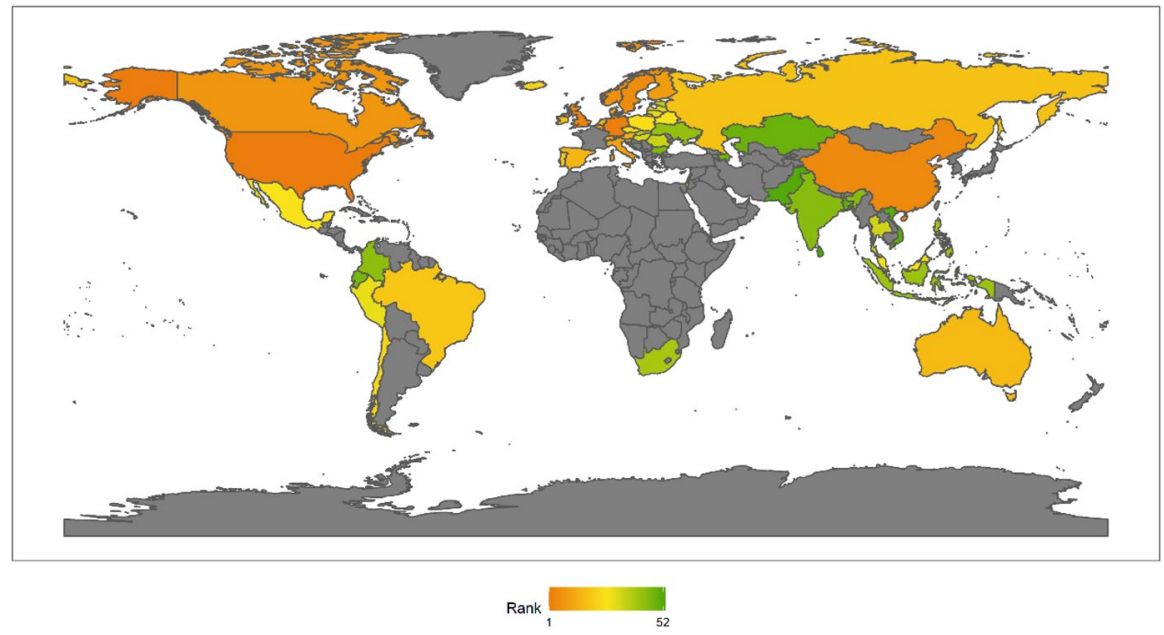

Fig. 252018 Index ranking of global justice (including all ten issues)

cooperation, (6) refugee, (7) anti-poverty, (8) education, (9) public health, and (10) the protection of women and children. Additionally, we have improved our data collection and strengthened the analysis section with more policy-oriented discussion.

Our results show that the United States, Germany, the United Kingdom, China, Sweden, Norway, Canada, Belgium, Finland and Italy are the top ten countries in 2018 in their contribution to global justice. The United States ranks 1st and China ranks the highest among developing countries. In our measurement last year, the final result covered merely 2010 to 2014 due to data limitations, and the top 


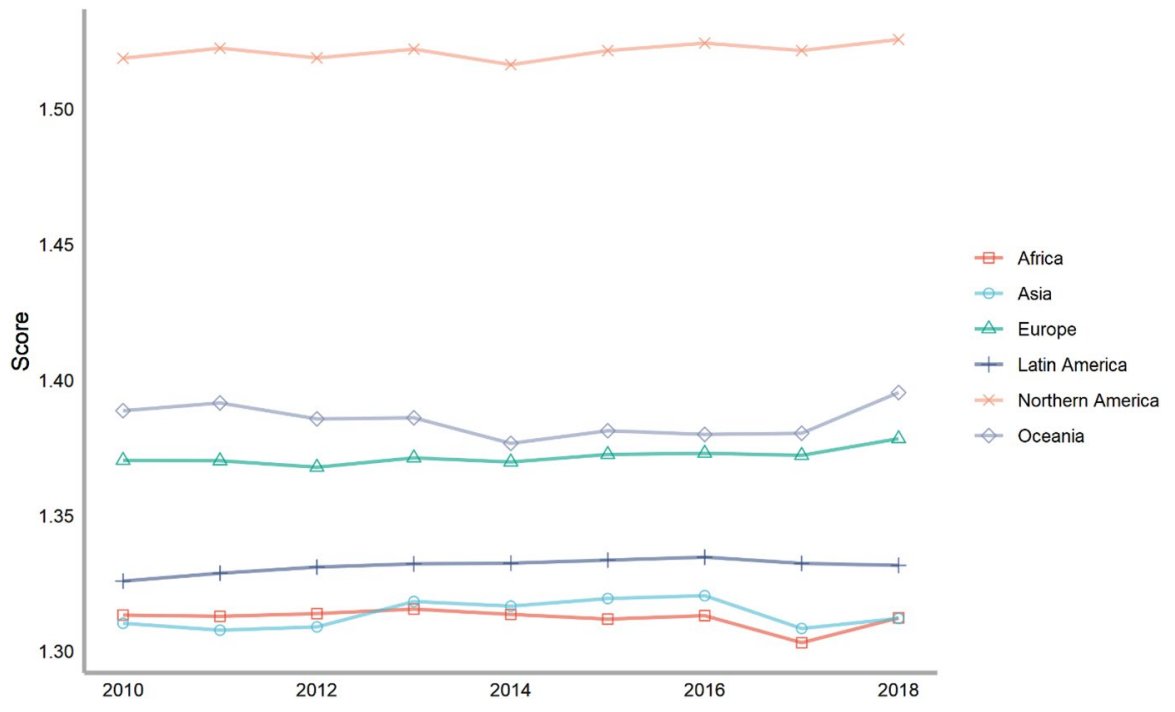

Fig. 26 The score of global justice index (including all ten issues) across continents, 2010-2018

five countries were the United States, the United Kingdom, Germany, China and France. Through improving the methodology and complementing missing data, we expanded the coverage to 2018 in this year's report and the result shows little change, which suggests the robustness of our global justice index.

This year's global justice index is our second release of the research result of the Global Justice Project which was initiated in 2018. The index is designed to empirically measure the performance and contribution of nation-states to enhancing justice at the global level by considering ten different issue areas. The following findings of this project have a number of implications: (1) the index provides the first comprehensive assessment of global justice development, which can be used by the international and regional communities to trace and monitor individual countries' performance, therefore pushing relevant policymakers to develop targeted interventions aimed at enhancing global justice; (2) the index establishes a quantitative framework for detecting changes and weakness in different issue areas of global justice. This information will be of assistance to country leaders and local practitioners to set policy priorities and invest continued efforts; (3) despite its exploratory nature, this index offers some insight into methodological approaches to measuring various justice-related variables, which will be of broad use to academic communities for conducting further causal analysis.

Several limitations to this index need to be acknowledged: (1) because no existing literature has provided solid evidence about how to determine the weight of the ten issues to global justice, we, therefore, assume that the ten issues equally contribute to global justice. However, in reality, a country's equal efforts in different issue areas may affect the ranking result to different degrees; (2) another limitation of using this index is that due to data availability problems, we were not able to include all nation states in the index. For some issue areas, such as poverty, climate 
change and education, this problem is particularly serious. This means that the ranking presented in the index may better be understood as a relative ranking, and the results may change as the data improves; (3) another caveat which needs to be noted regarding conducting comparisons is that a comparison of the global justice index ranking across the observation years and across different issue areas is inappropriate because each year/issue area in fact contains different numbers of countries due to the problem of missing data. This means that the ranking results need to be interpreted cautiously; (4) another source of weakness lies in the possibility of measurement bias. The measurement of some issue areas seems relatively simple. Although we have designed and collected a comprehensive set of indicators, not all the indicators have sufficient and reliable data to secure accurate measurement. In addition, we rely more on objective indicators. For example, on education, we have considered the school enrollment rate, but the measurement is limited by the lack of information on education quality. All these limitations, on the one hand, remind us to be prudent in interpreting the index results and on the other hand indicate that there is abundant room for further work.

Acknowledgements The Fudan IAS acknowledges the generous support it has received from institutions such as the Fudan University School of International Relations and Public Affairs, the Shanghai "Gao Feng" Disciplinary Supporting Funds, Global Policy, Rutgers University, as well as useful comments and suggestions on the project from the following individuals: Arthur Boutellis (International Peace Institute), Daniel Callies (UC San Diego), Jean Marc Coicaud (Rutgers University), Selda Dagistanli (Western Sydney University), Marco Dugato (Università Cattolica del Sacro Cuore), Sakiko Fukuda-Parr (The New School, New York), Yannick Glemarec (Executive Director, UN Green Climate Fund), Carlos Manuel Gradin Lago (UNU-WIDER, United Nations University World Institute for Development), Terry Lynn Karl (Stanford University), Milorad Kovacevic (Chief of Statistics, UN Human Development Report Office), Jane Mansbridge (Harvard University), and Philippe Schmitter (European University Institute). We are also grateful for helpful advice, comments, and suggestions from Yannick Glemarec, Executive Director, UN Green Climate Fund, and Milorad Kovacevic, Chief of Statistics, UN Human Development Report Office. We want to thank our research assistants for their time and important contributions in data collection and aggregation: Ziming Sang, Yingkai Wan, Qinzhu Sun, Zhijie Li, Xinyi Gu, Jiwen Zhang, Yifan Jia, Muye Nanshan, Wenyu Lin. We also thank other Fudan IAS fellows, Jean-Marc Coicaud, Su $\mathrm{Gu}, \mathrm{Xi}$ Lin, Qingping Liu, and Guodong Sun, for their active participation in and valuable contributions to our ongoing interactive discussions from their different perspectives, expertise, and knowledge. Finally, we also owe our thanks to the anonymous peer reviewers for their valuable comments and constructive criticism. All errors remain ours.

\section{Declarations}

Conflict of interest On behalf of all authors, the corresponding author states that there is no conflict of interest. Authors have no financial or personal relationship with a third party whose interests could be positively or negatively influenced by the article's content.

Open Access This article is licensed under a Creative Commons Attribution 4.0 International License, which permits use, sharing, adaptation, distribution and reproduction in any medium or format, as long as you give appropriate credit to the original author(s) and the source, provide a link to the Creative Commons licence, and indicate if changes were made. The images or other third party material in this article are included in the article's Creative Commons licence, unless indicated otherwise in a credit line to the material. If material is not included in the article's Creative Commons licence and your intended use is not permitted by statutory regulation or exceeds the permitted use, you will need to obtain permission directly from the copyright holder. To view a copy of this licence, visit http://creativecommons.org/licen ses/by/4.0/. 


\section{References}

Adger, W.N., K. Brown, D.R. Nelson, F. Berkes, H. Eakin, C. Folke, and E.L. Tompkins. 2011. Resilience implications of policy responses to climate change. Wiley Interdisciplinary Reviews: Climate Change 2 (5): 757-766.

Alkire, Sabina, and Maria Emma Santos. 2014. Measuring Acute Poverty in the Developing World: Robustness and Scope of the Multidimensional Poverty Index. World Development 59: 251-274.

Anderson, G.F., P. Hussey, and V. Petrosyan. 2019. It's still the prices, stupid: why the US spends so much on health care, and a tribute to Uwe Reinhardt. Health Affairs 38 (1): 87-95.

Andreas, P., \& Nadelmann, E. (2008). Policing the globe: Criminalization and crime control in international relations. Oxford University Press.

Appleton, C. 2014. Lone wolf terrorism in Norway. The International Journal of Human Rights 18 (2): 127-142.

Bara, C., and L. Hultman. 2020. Just Different Hats? Comparing UN and Non-UN Peacekeeping. International Peacekeeping 27 (3): 341-368.

Biondi, Paolo. 2016. Human security and external burden-sharing: the European approach to refugee protection between past and present. The International Journal of Human Rights 20 (2): 208-222.

Bogg, A. (2015). China and India as humanitarian donors: A regional case study in Southeast Asia.

Broadhurst, Roderic, Mark Lauchs, and Sally Lohrisch. 2014. Transnational organized crime in Oceania. In Transnational organized crime: an overview from six continents, ed. P. Reichel and J. Albanese, 141-162. United States of America: SAGE Publications Inc.

Broude, T., and D. Teichman. 2009. Outsourcing and insourcing crime: The political economy of globalized criminal activity. Vand. L. Rev. 62: 795-848.

Chin, G. T., \& Frolic, M. B. 2007. Emerging donors in international development assistance: the China case.

Coleman, K.P., and B. Nyblade. 2018. Peacekeeping for profit? The scope and limits of 'mercenary' UN peacekeeping. Journal of Peace Research 55 (6): 726-741.

Collier, P., G. Conway, and T. Venables. 2008. Climate change and Africa. Oxford Review of Economic Policy 24 (2): 337-353.

Cook, Rebecca J. 1995. Enforcing women's rights through law. Gender and Development 3 (2): 8-15.

Coolsaet, R. 2010. EU counterterrorism strategy: value added or chimera? International affairs 86 (4): $857-873$.

Crowley, T.J. 2000. Causes of climate change over the past 1000 years. Science 289 (5477): 270.

Davis, S. 2011. The US military base network and contemporary colonialism: Power projection, resistance and the quest for operational unilateralism. Political Geography 30 (4): 215-224.

Dreher, A., Fuchs, A., Parks, B., Strange, A., \& Tierney, M. J. 2017. Aid, China, and growth: Evidence from a new global development finance dataset.

Dwyer, J. 2005. Global health and justice. Bioethics 19 (5-6): 460-475.

Emmers, Ralf. 2003. ASEAN and the securitization of transnational crime in Southeast Asia. Pacific Review 16 (3): 419-438.

Ensor, Marisa O., and Amanda J. Reinke. 2014. African Children's Right to Participate in their Own Protection: Perspectives from South Sudan. The International Journal of Children's Rights 22: 68-92.

Fiddian-Qasmiyeh, Elena, Gil Loescher, Katy Long, and Nando Sigona, eds. 2014. The Oxford Handbook of Refugee and Forced Migration Studies. Oxford: Oxford University Press.

Finckenauer, J.O., and K.L. Chin. 2006. Asian transnational organized crime and its impact on the United States: developing a transnational crime research agenda. Trends in Organized Crime 10 (2): 18-107.

Finckenauer, J. O., \& Albanese, J. 2014. Transnational Organized Crime in North America. Transnational Organized Crime, 29-56.

Foertsch, V. 1999. The role of counterintelligence in countering transnational organized crime. Trends Organ Crim 5: 123-142. https://doi.org/10.1007/s12117-999-1036-z.

Gu, Y., X. Qin, Z. Wang, et al. 2020. Global Justice Index Report. Chinese Political Science Review, 5: 253-331.

Guo, S., X. Lin, J.M. Coicaud, S. Gu, Y. Gu, Q. Liu, and C. Zhang. 2019. Conceptualizing and Measuring Global Justice: Theories, Concepts, Principles and Indicators. Fudan Journal of the Humanities and Social Sciences 12 (4): 511-546. 
Hamman, S., and K. Omojuwa. 2013. The role of Nigeria in peacekeeping operations from 1960 to 2013. Mediterranean Journal of Social Sciences 4 (16): 27.

Hang, Z. 2013. Dragon under the Blue Helmet: a quantitative analysis of China's motivation for participation in UN peacekeeping operations. African East-Asian Affairs 3: 32-61.

Hatchard, John. 2006. Combating transnational crime in Africa: Problems and perspectives. Journal of African Law 50 (2): 145-160.

Heine, J., \& Thakur, R. 2011. The dark side of globalization, 5 INT'L STUD. REV

Hoffman, B. 1995. "Holy terror": The implications of terrorism motivated by a religious imperative. Studies in Conflict \& Terrorism 18 (4): 271-284.

Hufnagel, Saskia. 2014. Transnational Organized Crime: Police Cooperation in China and the EU. Griffith Asia Quarterly 2 (1): 75-92.

Hutchings, J. (Ed.). 2017. Accountability in Education: Meeting Our Commitments. UNESCO Publishing.

Johnston, R., and C. Deeming. 2016. British political values, attitudes to climate change, and travel behaviour. Policy \& Politics 44 (2): 191-213.

José María Aznar, Christopher J. Dodd, Frances G. Burwell and Gabriel Sánchez Zinny 2013. 'Tackling Transnational Crime and Boosting Public Security', Atlantic Council:28-31

Kah, H.K. 2013. Central African Republic: Understanding the Séléka Insurrection of March 242013. Conflict Studies Quarterly 5: 47-66.

Kathman, J.D., and M.M. Melin. 2017. Who keeps the peace? Understanding state contributions to UN peacekeeping operations. International Studies Quarterly 61 (1): 150-162.

Kingston, J. 2013. Nuclear power politics in Japan, 2011-2013. Asian Perspective 37 (4): 501-521.

Kneebone, Susan. 2016. Comparative regional protection frameworks for refugees: norms and norm entrepreneurs. The International Journal of Human Rights 20 (2): 153-172.

Lee Dr, S.E. 2013. Education as a Human Right in the 21st Century. Democracy and Education 21 (1): 1.

Lipson, M. 2007. A "garbage can model" of UN peacekeeping. Global Governance: A Review of Multilateralism and International Organizations 13 (1): 79-97.

Mark Gibney, 2010. Global Refugee Crisis: A Reference Handbook (Second Edition), ABC-CLIO.

Mills-Novoa, M., and D.M. Liverman. 2019. Nationally Determined Contributions: Material climate commitments and discursive positioning in the NDCs. Wiley Interdisciplinary Reviews: Climate Change 10 (5): 589.

Minns, John, Kieran Bradley, and Fabricio H. Chagas-Bastos. 2018. Australia's Refugee Policy: Not a Model for the World. International Studies 55 (1): 1-21.

Morgan, W. J., Gu, Q., \& Li, F. (Eds.). 2017. Handbook of education in China. Edward Elgar Publishing.

Mudde, Cas. 2019. The Far Right Today. London: Polity.

Nandini Krishnan et al., 2020, "Coping with the Influx: Service Delivery to Syrian Refugees and Hosts in Jordan, Lebanon, and Kurdistan, Iraq", World Bank Policy Research Working Paper no. 9326.

OECD. 2019. Health at a Glance 2019: OECD Indicators. OECD Publishing, Paris, . https://doi.org/10. 1787/4dd50c09-en.

Owen, David. 2018. Refugees and responsibilities of justice, 23-44. Theory Practice Rhetoric: Global Justice.

Papanicolas, I., L.R. Woskie, and A.K. Jha. 2018. Health care spending in the United States and other high-income countries. JAMA 319 (10): 1024-1039.

Pope, Amy. 2013. Partnering with Mexico to Fight Transnational Crime. GPSolo 30 (5): 66-67.

Ruger, J.P. 2009. Global health justice. Public Health Ethics 2 (3): 261-275.

Sadie Yang and Ao Li. 2009. Legal protection against gender discrimination in the workplace in China. Gender and Development 17 (2): 295-308.

Seelke, C. R. (Ed.). 2010. Latin America and the Caribbean: Illicit drug trafficking and US counterdrug programs. DIANE Publishing. P. 1

Selby, J. 2019. The Trump presidency, climate change, and the prospect of a disorderly energy transition. Review of International Studies 45 (3): 471-490.

Taylor, H. 2019. Domestic terrorism and hate crimes: legal definitions and media framing of mass shootings in the United States. Journal of policing, intelligence and counter terrorism 14 (3): 227-244.

Turubanova, S., P.V. Potapov, A. Tyukavina, and M.C. Hansen. 2018. Ongoing primary forest loss in Brazil, Democratic Republic of the Congo, and Indonesia. Environmental Research Letters 13 (7): 074028 .

UNDP 2017. From Commitment to Action: Policies to End Violence Against Women in Latin America and the Caribbean 
Velkova, Emi, and Saso Georgievski. 2004. Fighting Transborder Organized Crime in Southeast Europe through Fighting Corruption in Customs Agencies. Southeast European and Black Sea Studies 4 (2): 280-293.

Verhoeven, I. 2020. Contentious governance around climate change measures in the Netherlands. Environmental Politics, online first.

Versluys, Helen. 2008. Depoliticising and Europeanising Humanitarian Aid: Success or Failure? Perspectives on European Politics and Society 9 (2): 208-224.

Vichealth (2017), Violence against women in Australia: An overview of research and approaches to primary prevention

Woodward, Susan L. 2004. Enhancing cooperation against transborder crime in Southeast Europe: Is there an emerging Epistemic Community? Southeast European and Black Sea Studies 4 (2): 223-240.

World Bank. 2020. Poverty and Shared Prosperity 2020: Reversals of Fortune. Washington, DC: World Bank. https://doi.org/10.1596/978-1-4648-1602-4.

World Bank. 2018. Poverty and Shared Prosperity 2018: Piecing Together the Poverty Puzzle, 15. Washington, DC: World Bank.

World Health Organization. 2020. Health at a Glance: Asia/Pacific 2020 Measuring Progress Towards Universal Health Coverage: Measuring Progress Towards Universal Health Coverage. OECD Publishing.

Yue, A., Tang, B., Shi, Y., Tang, J., Shang, G., Medina, A., \& Rozelle, S. 2018. Rural education across China's 40 years of reform: past successes and future challenges. China Agricultural Economic Review.

Zaman, R.U., and N.R. Biswas. 2014. Bangladesh's Participation in UN Peacekeeping Missions and Challenges for Civil-Military Relations: A Case for Concordance Theory. International Peacekeeping 21 (3): 324-344.

Zarka, Salman, Morshid Farhat, and Tamar Gidron. 2019. Humanitarian medical aid to the Syrian people: Ethical implications and dilemmas. Bioethics 7 (3): 302-310.

Yanfeng Gu (Ph.D. in Social Sciences) is a lecturer and research fellow at the Fudan Institute for Advanced Study in Social Sciences (IAS-Fudan). He received his Ph.D. degree in social sciences at the Hong Kong University of Science and Technology. His primary fields are development economics, economic history, political economy, public administration, and social policy. His research interests include market integration, culture, social trust, and migration. His work has appeared in Chinese Sociological Review, Journal of Chinese Political Science, Journal of Chinese Governance, Sociological Study (in Chinese), and other leading journals in area studies.

Xuan Qin (Ph.D. degree in political science) is a lecturer and research fellow at the Fudan Institute for Advanced Study in Social Sciences (IAS-Fudan). She received her Ph.D. from the Nanyang Technological University (NTU Singapore). She is also a research assistant in the program of Participedia, which is developed by Archon Fung (Kennedy School of Government, Harvard University) and Mark E. Warren (Department of Political Science, University of British Columbia). Her current research interests include democratic theory, statistical analysis, and data visualization. She has published several articles in SSCI and CSSCI journals. She currently serves as an editor for the Chinese Political Science Review.

Zhongyuan Wang (Ph.D. in Political Science and China Studies) is a lecturer and research fellow at the Fudan Institute for Advanced Study in Social Sciences (IAS-Fudan). He received his doctoral degree from Leiden University (The Netherlands) and was a lecturer in the Program of International Studies at Leiden University. His research interests include comparative political institutions, election studies, political representation, local politics and governance, European politics, and governmental big data. His work has appeared in European Political Science, China Information, and the Journal of Contemporary China. He currently serves as an editor for the Journal of Chinese Political Science.

Chunman Zhang (Ph.D. degree in political science) is a senior lecturer and research fellow at the Fudan Institute for Advanced Study in Social Sciences (IAS-Fudan). He received his doctoral degree from the Johns Hopkins University. His research interests are comparative politics, party politics, environmental governance, and international relations. He has published over 25 academic papers in both English and 
Chinese leading journals, such as Environmental Politics, Land Use Policy, Journal of Chinese Political Science, and many other top CSSCI journals. He serves as an editor for Journal of Chinese Political Science.

Sujian Guo (Ph.D. degree in political science) is an honorary professor of the Fudan Institute for Advanced Study in Social Sciences; Principal Investigator of Fudan IAS Global Justice Index, Professor of Political Science and Director of the Center for US-China Policy Studies at San Francisco State University; former president of Association of Chinese Political Studies; Editor-in-Chief of the Journal of Chinese Political Science, the Journal of Chinese Governance, the Fudan Journal of the Humanities and Social Sciences, and the Chinese Political Science Review; Editor-in-Chief of Rowman \& Littlefeld-Lexington's book series "Challenges Facing Chinese Political Development," and Editor-in-Chief of Shanghai People's Press book series of "China in Transition." His research areas include comparative politics and Chinese politics, comparative political economy, Sino-US relations, sustainable energy and environment, democratic transition, and economic transition. He has published more than 60 academic journal articles and authored and edited 38 books, including Big Data and Social Sciences, Palgrave Handbook on Local Governance in Contemporary China, Governance in Transitional China; Political Science and Chinese Political Studies-The State of Field, The Political Economy of China's Great Transformation; Global Sustainable Energy Competitiveness Report; Democratic Transitions: Modes and Outcomes; Chinese Politics and Government: Power, Ideology and Organization; The Political Economy of Asian Transition from Communism; Post-Mao China, among others. 